\title{
O PRODUTO INTERNO BRUTO DO COMPLEXO AGROINDUSTRIAL BRASILEIRO
}

\author{
MARIA CRISTINA ORTIZ FURTUOSO \\ Economista Doméstica
}

Orientador: GERALDO SANT'ANA DE CAMARGO BARROS

\begin{abstract}
Tese apresentada à Escola Superior de Agricultura "Luiz de Queiroz", Universidade de São Paulo, para obtenção do título de Doutor em Ciências, Área de Concentração: Economia Aplicada
\end{abstract}

PIRACICABA

Estado de São Paulo - Brasil

Janeiro - 1998 
Dados Internacionais de Catalogação na Publicacão (CIP) DIVISĀO DE BIBLIOTECA E DOCUMENTAÇĀO - Campus "Luiz de Queiroz"/USP

Furtuoso, Maria Cristina Ortiz

O Produto Interno Bruto do complexo agroindustrial brasileiro / Maria Cristina

Ortiz Furtuoso. - Piracicaba, 1998.

$278 \mathrm{p}$.

Tese (doutorado) - E Escola Superior de Agricultura Luiz de Queiroz, 1998.

Bibliografia.

1. Economia agricola 2. Indústria agrícola 3. PIB I. Título

CDD 338.1 


\title{
O PRODUTO INTERNO BRUTO DO COMPLEXO AGROINDUSTRIAL BRASILEIRO
}

\author{
MARIA CRISTINA ORTIZ FURTUOSO
}

Aprovada em: $\quad 13.03 .1998$

Comissão Julgadora:

Prof. Dr. Geraldo Sant'Ana de Camargo Barros

ESALQ/USP

Prof. Dr. Joaquim José Martins Guilhoto

ESALQ/USP

Prof. Dr. Joaquim Bento de Souza Ferreira Filho

ESALQ/USP

Prof. Dr. Décio Zylbersztajn

FEAUSP

Prof. Dr. Erly Cardoso Teixeira

DER/UFV

Prof. Dr. GERALDO SANT A DE CAMARGO BARROS Orientador 
Dedico este trabalho

Aos meus pais, José e Julieta, Por tudo que me ensinaram

Ao meu esposo, Luiz Carlos Aos meus filhos, Thais, Felipe e Samira, que souberam dividir este valioso tempo, me apoiando e incentivando em todos os momentos. 


\section{AGRADECIMENTOS}

A Deus, pela vida.

Ao Professor Geraldo Sant'Ana de Camargo Barros, pelos ensinamentos transmitidos, inteligente orientação e pelo tempo que pôde me dispensar entre tantas outras atividades.

Ao Professor Joaquim José Martins Guilhoto, um agradecimento especial pelas brilhantes idéias e pela imprescindível colaboração.

Aos demais membros da banca examinadora, Professor Joaquim Bento de Souza Ferreira Filho, Professor Décio Zylbersztajn e Professor Erly Cardoso Teixeira, pelas valiosas e construtivas sugestões.

A Fundação Instituto Brasileiro de Geografia e Estatística (FIBGE) e a Fundação Getúlio Vargas (FGV), em especial ao Sr. Roberto Luis Olimpo Ramos do Departamento de Contas Nacionais (DECNA) e Sr. Lúcio Junqueira Campos do Centro de Estudos Agrícolas (IBRE/CEA).

Ao colega de doutorado, Warli Anjos de Souza, ao analista de sistemas do CIAQGRIUSP, Marcelo Corrêa Alves e ao técnico Claudinei Mori, pela colaboração nos trabalhos computacionais.

À Joselene Rodrigues Monteiro pelo convívio e pelos competentes serviços de digitação deste trabalho. 
Aos professores do Departamento de Economia e sociologia Rural da ESALQ e em especial àqueles com os quais convivi mais diretamente durante o curso de doutorado. A eles meu reconhecimento, esperando ter aprendido ao menos parte dos ensinamentos transmitidos.

Aos meus colegas de Departamento, pela convivência e trabalho conjunto. Um agradecimento especial, à Ana Maria Holland Ometto, pelo apoio e estímulo constante.

Gostaria de agradecer ainda aos funcionários do Departamento de Economia e Sociologia Rural e do Setor de Pós-Graduação da ESALQ. Em particular, as bibliotecárias, Maria Angélica e Luciane pelo auxílio e revisão no que se refere a aspectos bibliográfícos, e a Maria aparecida Maielli Travalini, pela atenção e amizade.

Por fim, agradeço a todos que, direta ou indiretamente, contribuíram para que este trabalho se concretizasse. 


\section{SUMÁRIO}

LISTA DE FIGURAS …........................................................... v

RESUMO .............................................................................

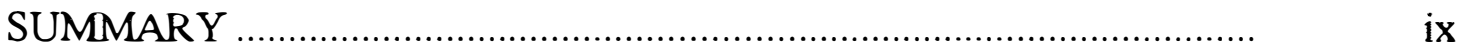

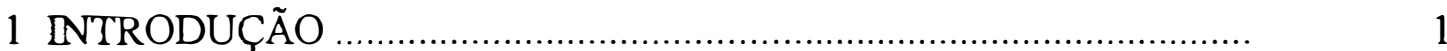

1.1 A EVOLUÇÃO DAS RELAÇÕES ENTRE A AGRICULTURA E A INDÚSTRIA 1

1.2 OBJETIVOS 15

2 FORMULAÇÕES GERAIS SOBRE O COMPLEXO AGROINDUSTRIAL .......................................................... 17

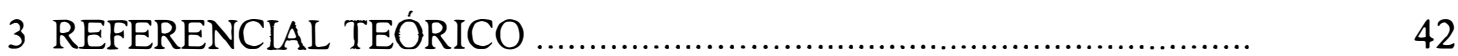

3.1 FONTES E TRATAMENTO DAS INFORMAÇÕES BÁSICAS ........................ 42

3.2 ESTRUTURA PRODUTTVA, SETORES-CHAVE E LIGAÇÕES

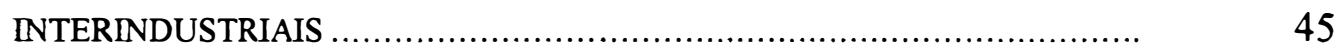

3.2.1 Os índices de Rasmussen-Hirschman ...........................................

3.2.2 O índice puro de ligações interindustriais .................................. 49

3.2.3 O enfoque do campo de influência ............................................ 54

3.3 OS SETORES INDUSTRIAIS LIGADOS À AGRICULTURA ...................... 56

3.4 PRODUTO INTERNO BRUTO .................................................... 58

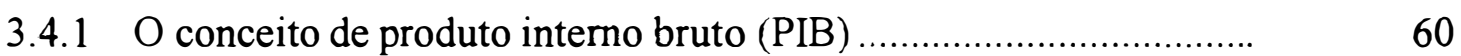

3.4.2 Metodologia e fórmula de cálculo .................................................. 64

3.4.3 Cálculo do Produto Interno Bruto do Complexo Agroindustrial Brasileiro ........................................................................... 67

3.4.4 Estimativa do Produto Interno Bruto a Preços Constantes .............. 76

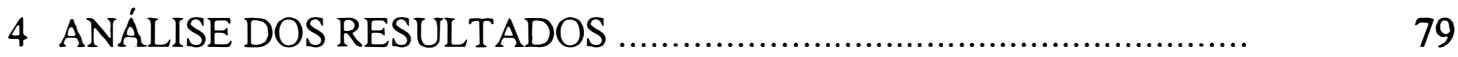

4.1 ESTRUTURA PRODUTIVA E SETORES-CHAVE .................................. 79

4.1.1 Estrutura produtiva da economia brasileira ................................. 79

4.1.2 Índices de ligações interindustriais e setores-chave ....................... 101

4.2 COMPOSIÇÃO DO COMPLEXO AGROINDUSTRIAL BRASILEIRO .......... 120

4.3 QUANTIFICAÇÃO DO COMPLEXO AGROINDUSTRIAL BRASILEIRO ..... 136

4.4 A EVOLUÇÃO DO COMPLEXO AGROINDUSTRIAL E DA AGRICULTURA NOS ANOS 80/94 _........................................... 161

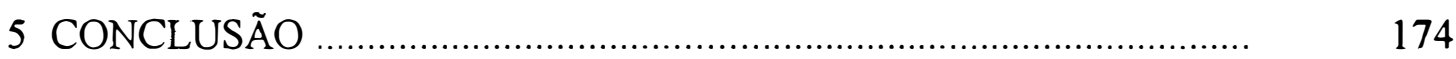

REFERÊNCIAS BIBLIOGRÁFICAS …......................................... 181 APÊNDICES ….................................................................... 


\section{LISTA DE TABELAS}

1 Produção, ativo total (investimentos) e emprego de mão-de-obra

Página ativa do complexo agroindustrial. Estados Unidos 1910, 1947, 1964 e 1965

2 Distribuição do valor adicionado entre os agregados no complexo

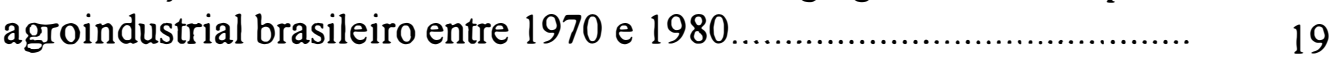

3 Tipologia da agricultura brasileira .................................................. 23

4 Contribuição do sistema alimentar para o PIB. 1980 ........................... 35

5 Consumo intermediário de diferentes setores industriais. Brasil 1980 . 69

6 Consumo intermediário de diferentes setores industriais. Brasil 1985. 70

7 Consumo intermediário de diferentes setores industriais. Brasil 1990. 71

8 Resumo das contas do complexo agroindustrial brasileiro ................... 75

9 Estrutura da produção (distribuição percentual). Brasil: 1980-19851990

10 Participação da demanda final na produção total (\%). Brasil: 19801985-1990

11 Participação dos insumos importados na produção total (\%). Brasil: 1980-1985-1990

12 Participação dos salários na produção total (\%). Brasil: 1980-19851990

13 Índices de ligação para trás de Rasmussen-Hirchman (BL). Brasil: 1980-1985-1990

102

14 Índices de ligação para frente de Rasmussen-Hirchman (FL). Brasil: 1980-1985-1990

15 Dispersão dos índices de ligação para trás (VBL). Brasil: 1980-19851990

105

16 Dispersão dos índices de ligação para frente (VFL). Brasil: 19801985-1990

17 Índice puro de ligação para trás (PBL). Brasil: 1980 (Cr\$ milhões) 1985 (Cr\$ bilhões) - $1990 \mathrm{Cr} \$$ milhões). Valores correntes

18 Índice puro de ligação para frente (PFL). Brasil: 1980 (Cr\$ milhões) 1985 (Cr\$ bilhões) - $1990 \mathrm{Cr} \$$ milhões). Valores correntes

19 Índice puro total de ligação (PTL). Brasil: 1980 (Cr\$ milhões) - 1985 (Cr\$ bilhões) - $1990 \mathrm{Cr} \$$ milhões). Valores correntes 
20 Setores ofertantes de insumos para a agropecuária. Valores correntes setoriais (impacto direto e indireto) e participação percentual de cada setor sobre o valor total (impacto total). Brasil - 1980

21 Setores ofertantes de insumos para a agropecuária. Valores correntes setoriais (impacto direto e indireto) e participação percentual de cada setor sobre o valor total (impacto total). Brasil - 1985

22 Setores ofertantes de insumos para a agropecuária. Valores correntes setoriais (impacto direto e indireto) e participação percentual de cada setor sobre o valor total (impacto total). Brasil - 1990

23 Estrutura do consumo intermediário da agricultura segundo os diferentes produtos. Brasil: 1980-1985-1990 (Distribuição percentual)

24 Setores demandantes de produtos agrícolas. Valores correntes setoriais (impacto direto e indireto) e participação percentual de cada setor sobre o valor total (impacto total). Brasil: 1980

25 Setores demandantes de produtos agrícolas. Valores correntes setoriais (impacto direto e indireto) e participação percentual de cada setor sobre o valor total (impacto total). Brasil: 1985

26 Setores demandantes de produtos agrícolas. Valores correntes setoriais (impacto direto e indireto) e participação percentual de cada setor sobre o valor total (impacto total). Brasil: 1990

27 Principais setores industriais, consumidores de insumos agropecuários (em \%) - 1980-1985-1990

28 Produto Interno Bruto a custo de fatores do complexo agroindustrial Brasileiro e do Brasil. 1980-1994.

29 Participação do Produto Interno Bruto a custo de fatores do complexo agroindustrial no PIB Brasileiro. 1980-1994 (Em porcentagem - \%) ..

30 Produto Interno Bruto a custo de fatores do complexo agroindustrial brasileiro e do Brasil. 1980-1994 (US\$ milhões)

31 Produto Interno Bruto a custo de fatores do complexo agroindustrial Brasileiro - 1980-1994. versão 1

32 Produto Interno Bruto a custo de fatores do complexo agroindustrial Brasileiro - 1980-1994. (Em Percentual) versão 1

33 Produto Interno Bruto a custo de fatores do complexo agroindustrial Brasileiro - 1980-1994. (US\$ milhões) versão 1

34 Produto Interno Bruto a custo de fatores do complexo agroindustrial Brasileiro - 1980-1994 versão 2

35 Produto Interno Bruto a custo de fatores do complexo agroindustrial Brasileiro - 1980-1994 (Em Percentual) versão 2 
36 Produto Interno Bruto a custo de fatores do complexo agroindustrial Brasileiro - 1980-1994 (US\$ milhões) versão 2

37 Produto Interno Bruto a custo de fatores do complexo agroindustrial Brasileiro - 1980-1994 versão 3

38 Produto Interno Bruto a custo de fatores do complexo agroindustrial Brasileiro - 1980-1994 (Em Percentual) versão 3

39 Produto Interno Bruto a custo de fatores do complexo agroindustrial Brasileiro - 1980-1994 (US\$ milhões) versão 3

40 Produto Interno Bruto a custo de fatores, segundo as classes de atividade econômica e Produto Interno Bruto a preços de mercado. Brasil - 1980-1994

41 Produto Interno Bruto a custo de fatores, segundo as classes de atividade econômica e Produto Interno Bruto a preços de mercado. Brasil - 1980-1994 (Em Percentual)

42 Produto Interno Bruto a custo de fatores, segundo as classes de atividade econômica e Produto Interno Bruto a preços de mercado. Brasil - 1980-1994 (Em Percentual)

43 Produto Interno Bruto a custo de fatores, segundo as classes de atividade econômica e Produto Interno Bruto a preços de mercado. Brasil - 1980-1994 (US\$ milhões)

44 Evolução dos índices de área cultivada, quantidade produzida e produtividade na agricultura brasileira, 1989/96. $(1989=100) \ldots \ldots \ldots \ldots . \quad 155$

45 Produção industrial - Geral e Setores. Brasil 1980-1996 ...................... 156

46 Produto Interno Bruto a custo de fatores, segundo as classes de atividade econômica e ramos de atividade econômica e Produto Interno Bruto a preços de mercado. Brasil - 1980-1994. Valores correntes ( $\mathrm{R} \$$ mil)

47 Evolução dos índices de preços reais de insumos agrícolas no Brasil, 1987/97. $(1994=100)$ 


\section{LISTA DE FIGURAS}

1 Estrutura representativa da dinâmica e da coordenação de atividades do complexo agroindustrial ................................................. 38

2 Estrutura da produção (distribuição percentual). Brasil - 1980 .......... 81

3 Estrutura da produção (distribuição percentual). Brasil - 1985 .......... 82

$4 \quad$ Estrutura da produção (distribuição percentual). Brasil - 1990 .......... 83

5 Participação da demanda final na produção total. Brasil - 1980 ........ 89

6 Participação da demanda final na produção total. Brasil - 1985 ........ 90

7 Participação da demanda final na produção total. Brasil - 1990 ........ 91

8 Participação das importações na produção total. Brasil - 1980 .......... 94

9 Participação das importações na produção total. Brasil - 1985 .......... 95

10 Participação das importações na produção total. Brasil - 1990 .......... 96

11 Participação dos salários na produção total. Brasil - 1980 ................. 98

12 Participação dos salários na produção total. Brasil - 1985 ................. 99

13 Participação dos salários na produção total. Brasil - 1990 ............... $\quad 100$

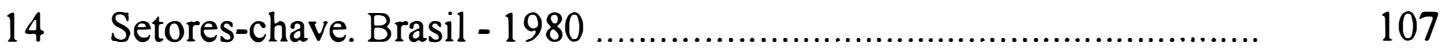

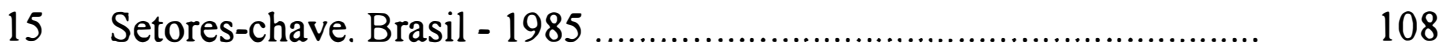

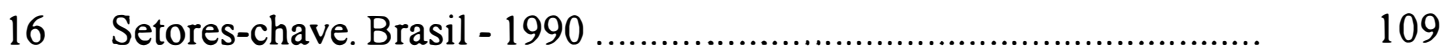

17 Coeficientes com o maior campo de influência. Brasil - $1980 \ldots \ldots \ldots . . \quad 116$

18 Coeficientes com o maior campo de influência. Brasil - 1985 .......... 117

19 Coeficientes com o maior campo de influência. Brasil - $1990 \ldots \ldots \ldots . . . \quad 118$

20 Relação de preços recebidos/pagos da agropecuária ........................ 154

21 Relação de preços no atacado agricultura/indústria ........................ 154

22 Evolução do valor adicionado. Complexo agroindustrial $\mathrm{x}$ indústria. Brasil - 1980/94. Base (média $1980=100$ ) ................................. 167

23 Evolução do valor adicionado. Agropecuária x distribuição final. Brasil - 1980/94. Base (média $1980=100$ )

24 Evolução do valor adicionado. Indústria de base agrícola $\mathrm{x}$ indústria. Brasil - 1980/94. Base (média 1980=100)

25 Evolução do valor adicionado. Indústria para agricultura. Brasil 1980/94. Base (média $1980=100$ )

26 Evolução do nivel de produção de produtos vinculados a agropecuária. Brasil - 1980/94. Base (média 1980 = 100)

27 Evolução do nível de produção da agropecuária. Brasil - 1980/94. Base (média $1980=100$ ) 


\title{
O PRODUTO INTERNO BRUTO DO COMPLEXO AGROINDUSTRIAL BRASILEIRO
}

\author{
Autora: MARIA CRISTINA ORTIZ FURTUOSO \\ Orientador: GERALDO SANT'ANA DE CAMARGO BARROS
}

\section{RESUMO}

O presente trabalho, utilizando informações provenientes das matrizes de insumo-produto calculadas pelo IBGE, analisa a evolução, ao longo do período compreendido entre 1980 e 1994, do Produto Interno Bruto (PIB) do Complexo Agroindustrial Brasileiro (CAI), da estrutura produtiva e dos índices de ligações interindustriais da economia brasileira. As abordagens de identificação de setores-chave tem importância, uma vez que além de propiciar uma visão mais compreensiva da economia e do desempenho e potencial dos setores agrícola e agroindustriais permitem desenvolver um procedimento analítico de delimitação do CAI.

Da análise da estrutura produtiva pode-se inferir que vem aumentando a complexidade da economia brasileira apresentando um estágio avançado com alto grau de interligação entre os setores produtivos nacionais, menor dependência de importações e uso intensivo do capital.

A análise dos índices de encadeamento da economia brasileira através de diferentes técnicas, mostra 0 predomínio dos setores Siderurgia, Metalurgia e 
Agropecuária em quase todos os enfoques. Alguns setores que compõem o segmento de produtos alimentares, também, assumem papel de importância dentro das relações intersetoriais, no que diz respeito ao encadeamento para trás. Os resultados apontam para uma crescente importância do segmento Serviços dentro da economia, seguindo a tendência deste ramo em economias desenvolvidas.

Para o procedimento analítico alternativo de delimitação dos componentes do Complexo Agroindustrial, estima-se as matrizes AGR que permitem identificar as interrelações entre as atividades agropecuárias e os demais setores da economia, em termos dos impactos diretos e indiretos. Esses resultados confirmam a grande articulação entre os setores componentes do CAI, refletindo a importância da atividade agrícola como setor de grande influência na estrutura produtiva do país através dos altos efeitos de encadeamento a montante e a jusante.

Em relação aos resultados do CAI, os dados empíricos mostram o papel fundamental que o "agribusiness" brasileiro tem desempenhado na economia nacional respondendo por cerca de $32 \%$ do produto interno bruto e apresentando complexas ramificações com agentes dos setores primário (agricultura), secundário (indústria) e terciário (serviços). Os resultados mostram, ainda, a expressiva perda de peso da Agropecuária no PIB do Complexo Agroindustrial, medido a custo de fatores, no período 1980/93 enquanto a Indústria de Base agrícola e o setor de Distribuição sobressaem-se como pólos mais dinâmicos, liderando esse processo de transformação agrária. A Indústria para Agricultura diminui grada-tivamente sua participação no PIB no mesmo período. 
A evolução da composição do Complexo Agroindustrial Brasileiro são confirmadores de que 0 "agribusiness" adiciona valor sobre as matérias primas agrícolas onde 0 setor de armazenamento, processamento e distribuição final tende a ser sempre mais representativo no valor total da produção vendida ao consumidor. 


\title{
THE GROSS NATIONAL PRODUCT OF THE BRAZILIAN AGROINDUSTRIAL COMPLEX
}

\author{
Author: MARIA CRISTINA ORTIZ FURTUOSO \\ Adviser: GERALDO SANT'ANA DE CAMARGO BARROS
}

\section{SUMMARY}

By means of information deriving from input-output matrices calculated by the IBGE (National Research of Sample per Home) this work analyzes the evolution of the Gross National Product (GNP) of the Brazilian Agroindustrial Complex ( $B A C)$, the productive structure, and interindustrial connection indexes of the Brazilian economy along the 1980 - 1994 period. Identification approaches of key sectors are important once they not only provide a more comprehensive view of economy and of the performance and potential of the agricultural and agroindustrial sectors but also allow the development of an analytical procedure delimit the BAC.

An analysis of the productive structure showed that the Brazilian economy complexity has increased and is at an advanced stage with a high degree of interconnection between national producing sectors, a lesser import dependence, and an intensive use of capital.

The analysis of linkage indexes of the Brazilian economy through different techniques shows the predominance of the metallurgical and agricultural sectors in almost every approach. Also some of the sectors forming the food Products segment undertake an important role within 
intersectorial relationships concerning backward linkage. The results point to an increasing significance of the Services segment within economy, following the tendency of this branch in developed economies.

For the alternative analytical procedure to delimitate the Agroindustrial complex components, the Matrix AGR allowing the identification of interrelationships between agricultural activities and other economy sectors regarding direct and indirect impacts are estimated.

These results ratify the great articulation between the sectors comprised by $B A C$ and reflects the significance of the agricultural activity as a sector of great influence on the productive structure of the country through high linkage effects, rising and ebb tides.

Regarding $B A C^{\prime} s$ results, empirical data show the fundamental role that the Brazilian agribusiness has played at the national economy, with approximately $32 \%$ of the GNP and complex branches with the primary (agriculture), secondary (industry), and tertiary (services) sectors agents.The results showed an expressive loss of importance of agriculture for the GNP of the Agroindustrial Complex, measured at factors cost in the $1980 / 93$ period while the basic agricultural industry and the distributing sector are outstandingly more dynamic poles and leaders of this agrarian transformation process. The Industry for Agriculture gradually decreases its participation at the GNP during the same period.

The evolution of the Brazilian Agroindustrial Complex composition confirms that agribusiness adds value to the agricultural raw material where the storage, processing, and final distribution sector always tends to 
be more representative in the total value of the production sold to consumers. 


\section{INTRODUÇÃO}

\subsection{A evolução das relações entre a Agricultura e a Indústria}

A história da agricultura brasileira mostra o papel fundamental que esse setor sempre desempenhou no desenvolvimento da economia do país. A literatura econômica apresenta vastas publicações que detalham os surtos econômicos brasileiros, durante os chamados "ciclos" do gado, da canade-açúcar, da borracha, do cacaul, etc. Ainda hoje, a atividade agrícola continua contribuindo de maneira significativa sob vários aspectos econômicos e sociais. Por exemplo, do total exportado pelo Brasil, anualmente, cerca de $40 \%$ são oriundos da exportação de gêneros agropecuários. A fim de dar uma magnitude do que representa a agricultura na balança comercial, podemos observar que em 1980, a participaÇão dos setores alimentação, têxteis, vestuário, madeira, borracha e minerais não-metálicos foram respectivamente: $14,4 \% ; 6,5 \% ; 6,9 \% ; 9,6 \% ; 1,2 \%$ e 1,5\% (SILBER, 1988).

Essa tradição econômica que o país possui na agricuitura, ainda que com diferentes graduações, é uma tendên-

1 EURTADO (1976), PAIM (1957), SZMRECSANYI (1990), SIMONSEN (1969). 
cia que deverá prevalecer no futuro, principalmente em razão dos seus vastos recursos naturais. No entanto, o avanço da economia em muito dependerá da "performance" dos produtos primários, quer tenham como destino a exportação ou o consumo interno. Neste sentido, existe uma extensa literatura $^{2}$ que apresenta evidências empíricas que comprovam o processo de inversão da tendência do padrão de crescimento que o setor agricola brasileiro vem experimentando desde a crise econômica dos anos 80, quando ocorre a perda da dinâmica das exportações em favor do maior dinamismo do mercado interno. Porém, é de importância fundamental salientar as mudanças substanciais que vêm ocorrendo em nível mundial no relacionamento da agricultura com os outros setores da economia.

Para efeitos desta apreciação, lembremos da figura originária do camponês europeu. "A unidade familiar, que coincidia com a unidade rural, operava próxima à autosuficiência, em que seus integrantes se dedicavam à plantação e criação comercial, mas também criava seus animais de tração, produzia seus instrumentos de transporte, suas ferramentas e demais itens necessários. Seus membros produziam - próprio pão, bebiam o próprio vinho e até as roupas eram feitas em casa e todo o processamento do alimento era doméstico. Todas as operações relacionadas com o cultivo, o processamento, o armazenamento e a comercialização dos produtos eram funções da fazenda" (Barros de Castro, 1969). Nessas circunstâncias, era perfeitamente coerente aglutinar todas essas atividades dentro do significado do termo agricultura.

2 LOPES (1987), MANOEL \& BARROS (1987), DIAS (1989), RESENDE (1988). 
Ao passarmos à análise do caso brasileiro, há que assinalar preliminarmente que este país contou com dois modelos agrícolas: "plantation" e de subsistência. ${ }^{3}$ Como descreve Jank et al. (1995), a agricultura de "plantation" caracterizou os ciclos econômicos de nossa história: gado, cana-de-açúcar, café, cacau e borracha. Esta forma de agricultura se distingue por apresentar grandes extensões de terras e monocultura, os grandes latifúndios, com alto grau de independência operacional, sendo explorados por técnicas de agricultura extensiva, em que o produto final fundamentalmente destinava-se ao mercado externo. Até o início da Segunda Guerra Mundial, a economia brasileira dependia grandemente das lavouras de exportação. O outro modelo de agricultura - de subsistência - coexistia com o primeiro, através da pequena propriedade, apresentando pequenas extensões de terra e policultivo. Cabe salientar que apesar de pobre e ineficiente, a agricultura de subsistência atendeu à procura de alimentos e matérias-primas pela população urbana e a mão-de-obra rural das "plantations". " Nessa época, a unidade produtiva agrícola era praticamente autosuficiente que constituía o chamado "setor primário".

Juntamente com a revolução tecnológica da agricultura em nível mundial no período do pós-guerra, as atividades agrícolas tiveram ampla expansão e crescente especialização, influenciadas decisivamente pelo desenvol-

3 Coexistem neste campo teses discrepantes a respeito do desempenho da agricultura no desenvolvimento brasileiro. A esse respeito pode-se consultar os trabalhos de: LAMBERT(1967), GUIMARAES (1977), OLIVEIRA (1946), EURTADO (1964), ERANK (1967), DELFIM NETTO (1966), entre outros.

4 DELFIM NETTO (1966) baseando-se numa análise de projeções de demanda de produtos alimentares e confrontando-as com o crescimento da respectiva oferta, conclui que: "não existem razões... para que a pro- 
vimento econômico e a crescente urbanização. Esse processo, basicamente, impôs uma nova ordem agrícola em que o moderno agricultor é um especialista envolvido com as operações de cultivo e criação de animais, transferindo as funções de armazenar, processar e distribuir produtos agropecuários, bem como de suprimento de insumos e fatores de produção, para organizações além da fazenda.

A agropecuária antes voltada exclusivamente para a auto-suficiência, modernizou-se, inserindo-se na economia de mercado e constituindo novos elos ou segmentos do sistema alimentar. Basicamente, esse processo resultou na estruturação de um moderno parque industrial que fornece bens de capital e insumos para o campo, setor denominado a montante da fazenda. Por outro lado, formaram-se complexas redes de armazenamento, transporte, processamento, industrialização e distribuição, setor a jusante.

Atualmente, o valor das atividades ligadas à agricultura, realizadas fora da fazenda, são substancialmente maiores do que o total das operações nela realizadas. Como exemplo, Pinazza (1986) cita o caso dos Estados Unidos, segundo dados de 1975, cuja composição percentual do complexo agroindustrial ${ }^{5}$ já representava: 35\% para insumos, 15\% para agricultura e 50\% para indústria e distribuição. Evidência clara desse fenômeno é que, em nível mundial, esse complexo engloba mais da metade dos ativos totais, emprega mais da metade da mão-de-obra e representa metade das despesas dos consumidores. Em 1989 o procuto Interno Bruto (PIB) agrícola dos EUA foi de U\$161 bilhões e o PIB do complexo agríco-

cura de alimentos aqui considerada tenha crescido mais rapidamente que sua oferta".

5 No capitulo 2 apresenta-se uma discussão mais rigorosa dos conceitos e abordagens relativas as atividades relacionadas à agricultura. 
la foi de U\$1.600 bilhões, ou seja, são gerados cerca de dez dólares para cada dólar de produto agrícola (Jank et al., 1995).

Em decorrência deste fenômeno, o conceito tradicional da economia que classifica as diferentes atividades em setores "primário, secundárío e terciário", como setores estanques e não integrados ceu lugar a uma análise que enfoca um sistema interligado de produção, processamento e comercialização dos produtos de origem agrícola - o Complexo Agroindustrial.

A contribuição acadêmica pioneira para quantificar essa abordagem conceitual surgiu em 1957, quando os economistas norte-americanos Ray Goldberg e John H. Davis criaram $O$ termo Agribusiness. Os autores, fazendo uso das técnicas matriciais de insumo-produto, desenvolvidas por Wassily Leontief, estudaram as transformações e a reestruturação da agricultura. Analisando os problemas relacionados com o setor agrícola da economia afirmavam que esses eram muito mais complexos e não se restringiam a simples atividade rural. Daí a necessidade de se tratar os problemas agrícolas sob um enfoque sistêmico (Agribusiness) e não mais estático (agricultura).

Davis e Goldberg (1957, 1968), analisando o complexo agroindustrial norte-americano entre 1910, 1947 e 1965, observaram que a soma das Eunções ligadas à agricultura, realizadas fora da fazenda, cresceram significativamente nesse período, e se tornaram consideravelmente maiores que - total das operações realizadas no âmbito da fazenda propriamente dita. Estimaram que, após a consolidação das grandes transformações no setor rural, na nova estrutura do complexo agroindustrial norte-americano, em 1965, da produ- 
Ção agropecuária comprada pelos consumidores, o campo produziu somente $11 \%$ e a cidade 0 restarze, aproximadamente 89\% (Tabela 1, Davis \& Goldberg, 1957, citado por Lauschner, 1993).

Sabe-se que esse processo de expansão e especialização da agricultura não ocorreu de forma homogênea em todas as regiões do planeta, pois depende do estágio de desenvolvimento econômico e social de cada uma delas. Ou seja, a participação e a interação dos agentes - agricultores, fornecedores de insumos e fatores de produção, processadores e distribuidores - ocorreram em graduações diferentes nos vários níveis do sistema agroalimentar (Pinazza \& Araújo, 1993).

É indubitável que o crescimento do complexo agroindustrial mundial continuará se processando de forma desigual entre os diferentes níveis da cadeia vertical. Entretanto, projeções realizadas do complexo agroindustrial mundial até o ano 2028 mostram que as funções de processamento e distribuição representarão cerca de $81,6 \%$ de todo 0 faturamento do sistema, contra $62,4 \%$ e 50,0\%, respectivamente, em 1980 e 1950. A agricultura terá sua participação reduzida de 32,4\% em 1950 para 9,6\% em 2028, enquanto os fornecedores de insumos e fatores de produção também terão sua participação reduzida no período de $17,6 \%$ para $8,8 \%$ (Goldberg, 1990). 


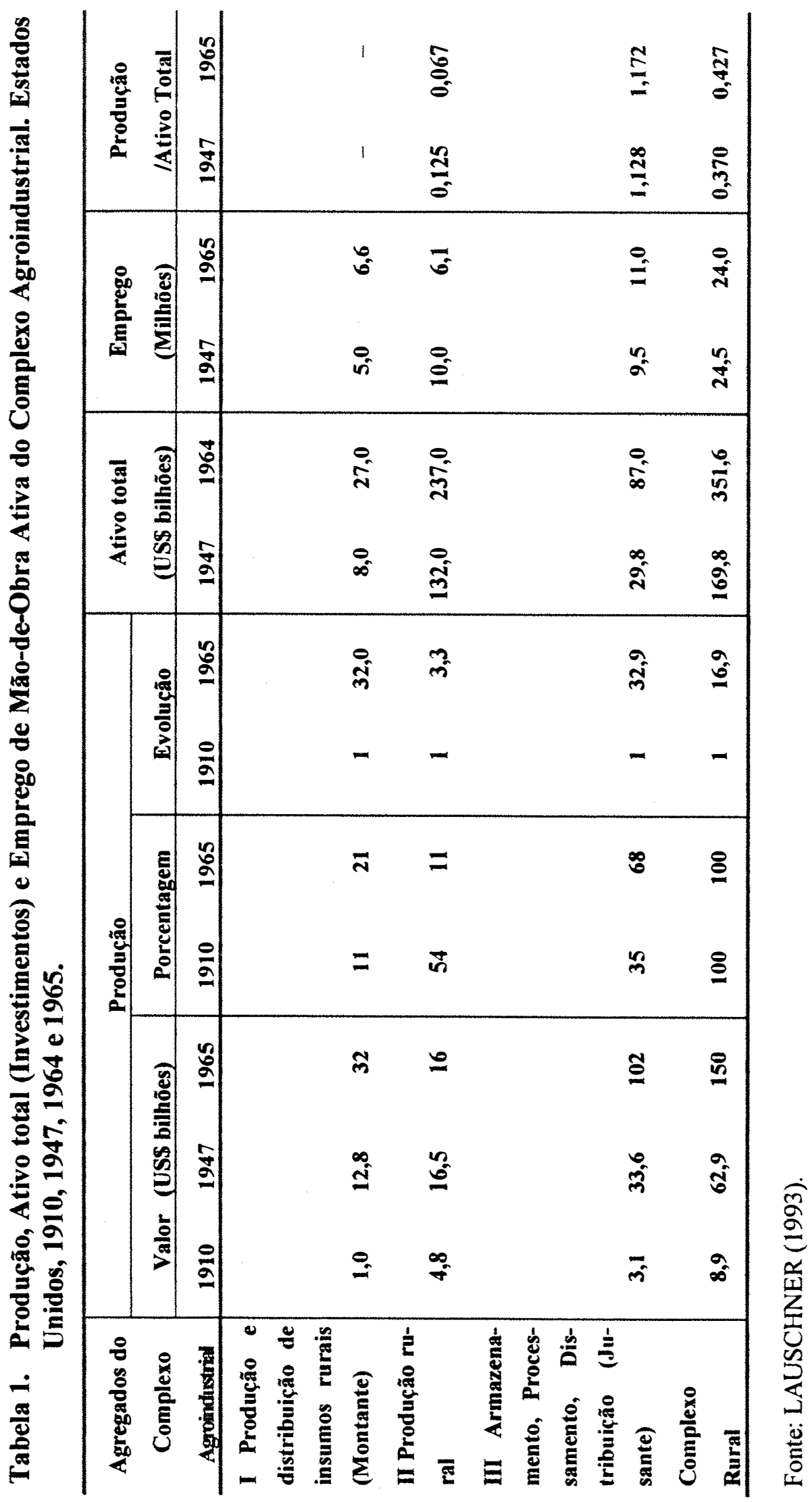


A agricultura brasileira incorporou esse processo de transformações ocorridas em nível mundial. A atividade agropecuária foi redirecionada, modernizando-se e integrando-se ao mercado. Essas transformações e reestruturações do setor rural iniciaram-se a partir dos anos 50, que, paralelamente ao crescimento extensivo da produção agrícola, passa por um processo de modernização de sua base técnica, com atuação efetiva do Estado.

o processo de modernização da agricultura brasileira se inicia com a introdução de maquinários, de elementos químicos (fertilizantes, defensivos, etc.), novas ferramentas e culturas. É definida como uma mudança na base técnica da produção em que há a substituição da produção artesanal rural por uma agricultura moderna, intensiva e mecanizada. ${ }^{6}$ Segundo Kageyama (1990), esse processo implica tanto numa integração intra-setorial como na mercantilização da agricultura promovendo a substituição de componentes internos usados no setor rural por compras extra-setoriais (máquinas e insumos), oferecendo condições para o desenvolvimento de indústrias de bens de capital e insumos para a agricultura.

Dados apresentados por Kageyama (1990) mostram que - crescimento do consumo intermediário como porcentagem do valor bruto da produção agropecuária passou de uma participação de cerca de 10\%, em 1949, para 25\% no final da década de 60 e atingindo aproximadamente 40\% em 1980. A participa-

6 "Em certa medida, a modernização do campo é restringida pela capacidade de importar, enquanto depende da importação dos insumos de sua nova base técnica" (KAGEYAMA, 1990).

"O consumo intermediário significa o valor de todos os insumos de bens e serviços que desaparecem no decorrer do processo de produção. Englobam as despesas com sementes, defensivos, fertilizantes, rações e medicamentos para animais, aluguel de máquinas, embalagens e outros itens que possam ser considerados matérias-primas ou insumos produtivos (RIBEIRO \& GHEVENTER, 1983). 
Ção do consumo intermediário no valor da produção representa uma medida do processo de modernização, que indica a dependência da agricultura de compras industriais para a produção de suas mercadorias. Ressalte-se que a intensificação do crescimento da participação do consumo intermediário na agricultura ocorre a partir dos anos 60 .

No período pós-65, o processo de modernização entra numa fase mais avançada, a de industrialização da agricultura brasileira, "... que representa mudança qualitativa fundamental no longo processo de transformação da sua base técnica, o que torna o processo de modernização irreversível". (Ver Kageyama, 1990)

Kageyama (1990) discorre sobre três transformações básicas que diferenciam a modernização agrícola do processo de industrialização. Primeiro, não se resume apenas à utilização de insumos modernos na produção agrícola. A industrialização do campo envolve um processo de mudança nas relações de trabalho, passando a ser essencialmente uma relação de trabalho coletivo (cooperativo) onde o trabalhador individual é substituido por trabalhadores assalariados voltados para uma determinada atividade. A segunda alteraÇão qualitativa é quando se incorpora a mecanização de todo - processo produtivo. A terceira grande mudança qualitativa é a internalização do Departamento de Meios de Produção para a Agricultura $\left(D_{1}\right)$, ou seja, implantação e desenvolvimento dos setores produtores de bens de capital e insumos para a agricultura. Segundo a autora, a partir daí, a capacidade de modernização do setor passa a ser endógena. Devese lembrar que a modernização em seu início se processava através de importações, o que restringia grandemente a generalização deste processo. 
A análise da evolução do setor industrial produtor de bens de produção para a agricultura está razoavelmente tratada na literatura sobre modernização e produtividade do setor agrícola brasileiro. Com efeito, os estudos mostram uma importante expansão do setor nas últimas décadas, especialmente a partir da implantação da estratégia de modernização agrícola. Para uma análise mais pormenorizada da constituição do setor, ver entre outros, Baum (1977), Barros et al. (1980) e Contador \& Ferreira (1984).

A propósito do processo de consolidação do $D_{1}$ (Departamento de Meios de Produção para a agricultura), vale ressaltar que esse setor industrial desenvolveu-se concomitantemente com o processo de substituição de importações de outras indústrias de base nacional. No entanto, seu grande momento ocorre somente após a metade dos anos 60 quando a produção interna se acelera. Os dados revelam que a produção nacional de fertilizantes inorgânicos atinge volume significativo em 1973 e a indústria de tratores e implementos agrícolas pesados iniciou suas atividades em 1960 e desde então o setor vem crescendo a taxas significativas de $18 \%$ ao ano em média (Barros \& Manoel, 1992).

Essas transformações foram dinamizadas, em grande parte, pelo Sistema Nacional de Crédito Rural, através de grandes disponibilidades de crédito subsidiado, conjugado com a implantação de novos blocos de substituição de importações de meios de produção para a agricultura através do II Plano Nacional de Desenvolvimento (1974/79)(Barros, 1983).

Neste contexto, como conseqüência, a agricultura brasileira registra profundas transformações a partir de meados da década de 60 até os anos 80: "O setor cresce a taxas expressivas; 0 crescimento da produtividade da terra 
passa a explicar cerca de $61,4 \%$ do crescimento da produção; a produtividade do trabalho cresce em torno de 1,9\% ao ano; altera-se o mix da produção com a evolução da cultura da soja, por exemplo; ocorre também uma expansão da fronteira agrícola em direção aos limites geográficos do Brasil Central e região Norte" (Alves, 1989).

Vale lembrar que, embora estas transformações tenham sido intensas e dominantes, não ocorreram de forma uniforme entre regiões e produtos.

Esse processo culmina na constituição dos complexos agroindustriais (CAIs) nos anos 70, que se dá a partir da integração intersetorial entre as indústrias que produzem para a agricultura, a agricultura (moderna) propriamente dita e as agroindústrias processadoras. A produção agrícola passa então a fazer parte de uma cadeia e a depender da dinâmica da indústria, ou seja, há uma crescente integração da agricultura à indústria onde o corte setorial agricultura/indústria perde importância. ${ }^{8}$

Um papel-chave nesse padrão atual de desenvolvimento da agricultura é o desempenhado pelo Estado como elemento aglutinador, através das politicas governamentais específicas (fundos de financiamento para determinadas atividades agroindustriais, programas de apoio a certos produtos agrícolas, etc. (Kageyama, 1990).

Silva (1993) explicita os impactos fundamentais esperados da formação dos CAIs sobre a estrutura produtiva do país. Para o autor, a concentração e centralização de capitais tende a crescer nos próximos anos, em função da esperada consolidação dos CAIs na década de 90. Cálculos disponíveis, com base em dados censitários de 1975, 1980 e

\footnotetext{
s Ver Silva, 1993.
} 
1985, mostram que menos de 10\% dos estabelecimentos rurais brasileiros estariam engajados no novo sistema de produção. Essas informações mostram o caráter heterogêneo da chamada modernização da agricultura brasileira, tanto no que se refere ao tamanho dos produtores como a região de localização que atinge principalmente os médios e grandes produtores e as regiões Centro-Oeste, Sudeste e Sul. Entretanto, para Silva a heterogeneidade da modernização agrícola não deve ser associada a idéia de atraso, uma vez que esses 10\% de estabelecimentos rurais representavam um terço da produção agropecuária do país já em 1975, subindo para cerca de 50\% em 1980 (Silva, 1993). Estudo da FAO (Guazirole, 1994) mostra que a agricultura familiar para 15 produtos importantes produz mais de 50\% deles. Ratificando as estatísticas nacionais, pesquisas mais recentes de mercado realizadas pelas indústrias de insumos indicam a ocorrência de uma crescente concentração de produção e profissionalização dos empresários do campo.

A especialização e a busca de economia de escala são os meios pelos quais os produtores rurais procuram acompanhar o movimento de modernização. Os desenvolvimentos tecnológicos esperados tanto no que diz respeito a colheita, carregamento e transporte irão contribuir para a redução dos custos de produção das "commodities" agrícolas. Pesquisas feitas pela Universidade de Brasília, citados por Wedekin (1994), mostram que o "custo de produção de soja nos cerrados chega a diminuir 40-45\% quando a área de cultivo passa de 50 para 1 mil hectares. Para obter melhores resultados na comercialização da safra, os representantes do segmento mais dinâmico do setor agricola brasileiro pressionam as indústrias de insumos e bens de capital por 
novos e melhores produtos; aderem a novos processos de produção e aprimoram o sistema de informações".

Outra importante tendência em relação à estrutura produtiva diz respeito à crescente integração com o setor de serviços e com os fornecedores de insumos gerando os "CAIs completos", os quais apresentam ligações específicas com a agroindústria tanto "à frente" lagroindústria processadora) como "para trás"(indústria fornecedora de insumos e equipamentos) (Silva, 1993).

Barros (1985) num estudo sobre agroindústria e comercialização estima o grau de integração da agricultura brasileira aos segmentos do Complexo Agroindustrial. O procedimento adotado foi o de empregar os parâmetros utilizados pela Fundação Getúlio Vargas na elaboração das Contas Nacionais. Cada segmento do setor produtor de insumos foi avaliado em termos da proporção do valor da produção agropecuária que absorve. Quanto aos segmentos referentes à comercialização e industrialização, sua importância foi avaliada em termos da proporção que o produto agrícola a ele referente representa no produto de cada segmento. Os resultados mostram que 90,9\% do valor da produção agropecuária se destina à comercialização. Já o setor distribuição conta com 52\% do valor de sua produção provenientes da agricultura. No segmento agroindustrial, a produção agropecuária varia, sendo que a indústria têxtil e a de alimentos são as que apresentam as maiores relações insumo-produto (56\% e 46,2\% respectivamente).

Dados apresentados por Jank (1990) mostram como a recente "performance" das exportações agrícolas brasileiras reflete, na verdade, as profundas alterações ocorridas na agricultura brasileira nas últimas décadas. Os produtos agrícolas tradicionais (açúcar, café, cacau e algodão) que 
representavam 70\% das exportações totais da agroindústria no início da década de 70 passaram para menos de 30\% nos anos 90, e os novos complexos agroindustriais ganharam maior espaço no cenário mundial, particularmente os produtos com maior agregação de valor. Por sua vez, Pfeifer Filho (1990) aponta a agroindústria como um segmento de dupla importância, conquistando mercados externos e garantindo o abastecimento interno.

Em sintese, as considerações anteriores deixam patente que a integração da agricultura à indústria implica uma verdadeira reestruturação do setor rural, estabelecendo profundas relações tecnológicas, produtivas, financeiras e de negócios com as demais atividades da economia. Amplia-se a visão sistêmica no fluxo produção-consumo e as cadeias agroalimentares ganham espaços junto ao mercado interno e ao mercado mundial de alimentos.

No Brasil, são escassos os levantamentos sobre 0 Complexo Agroindustrial, e as pesquisas disponiveis comumente apresentam problemas em relação a abrangência e a periodicidade. Nos aspectos ligados a questão alimentar ainda prevalece o enfoque funcional assim como na literatura econômica predomina a análise da agricultura propriamente dita. Por sua vez, a Fundação IBGE, que é a instituição responsável pelo cálculo das Contas Nacionais do Brasil, adota metodologia em que apresenta separadamente os três setores econômicos - agricultura, indústria e serviços dificultando a análise intersetorial. 


\subsection{Objetivos}

Partindo da percepção dessa nova dinâmica de inserção da agricultura à indústria, que se caracteriza por um fenômeno de alcance mundial e irreversível, a perspectiva deste trabalho é analisar o comportamento do Complexo Agroindustrial Brasileiro nos últimos anos, no contexto dessas transformações.

A compreensão da articulação agricultura/indústria permite aprofundar a teoria sobre o mesmo, explicitando alguns aspectos estruturais que orientem a reflexão. Do mesmo modo, é indiscutível sua validade para efeito de subsídios ao planejamento das politicas setoriais como também ao gerenciamento do Complexo Agroindustrial.

Desta forma, objetiva-se delinear uma metodologia de cálculo do Produto Interno Bruto (PIB) para o Complexo Agroindutrial Brasileiro, assim como quantificar o desempenho e evolução do setor agrícola e do conjunto de setores industriais vinculados à agricultura nas últimas décadas (período 1980 a 1994).

Com esses objetivos, este trabalho apresenta, inicialmente (Capitulo 2), uma revisão de trabalhos que abordam a agricultura sob uma perspectiva sistêmica tanto no que se refere a descrever as transformações agrícolas nas últimas décadas como no de conceituar as diferentes noções usualmente empregadas.

No Capítulo 3 encontram-se as informações básicas dos dados utilizados bem como dos procedimentos metodológicos adotados. A análise da estrutura produtiva brasileira e dos indices de ligações interindustriais visando a determinação de setores-chave tem 0 intuito de propiciar uma visão mais compreensiva da economia a nível nacional e em especi- 
al do desempenho e potencial dos setores agrícola e agroindustriais. As abordagens de identificação de setores-chave tem importância, uma vez que permitem desenvolver um procedimento analítico de delimitação dos componentes do complexo Agroindustrial. Complementando, apresenta-se uma descrição das conceituações, metodologias de estimativas do Produto Interno Bruto e fórmula de cálculo utilizada para obtenção do PIB do Complexo Agroindustrial; no Capítulo 4 encontram-se os resultados empíricos obtidos; e, finalmente, no Capítulo 5 apresentam-se as conclusões. 


\section{FORMULAÇÕES GERAIS SOBRE O COMPLEXO AGROIN- DUSTRIAL}

- Complexo Agroindustrial, CAI, pode ser definido formalmente como um conjunto formado pela sucessão de atividades vinculadas à produção e transformação de produtos agropecuários e florestais (Müller, 1989). Entre os grupos econômicos atrelados ao setor agrícola, podemos visualizar um conjunto de atividades econômicas envolvendo empresas que oferecem produtos e serviços para a agricultura, denominado de indústria para a agricultura, compondo a cadeia retrospectiva da agropecuária, setor a montante, ou seja, as empresas que se incumbem da produção de bens de capital e de insumos industriais para o setor rural. Também, há aqueles grupos que adquirem da agricultura suas matériasprimas, denominados de agroindústria e constituindo a cadeia prospectiva da agropecuária, setor a jusante. Como argumenta Santana (1994) estes grupos, muitas vezes influenciados pela política econômica, imprimem à agricultura uma dinâmica industrial auxiliando na superação da forma tradicional de produzir no campo. Assim, a agricultura pode estar vinculada a setores industriais e até mesmo comerciais, dependendo não somente do crescimento da agroindústria, do mercado interno e de exportação, como também da indústria produtora de insumos e máquinas e das institui- 
ções de ensino e pesquisa. Esse conjunto de atividades, agrícolas e industriais, são interdependentes, mas heterogêneos quanto ao grau de importância na evolução do complexo Agroindustrial (CAI).

Esta definição foi catizada pelo termo "Agribusiness" por Davis \& Goldberg (1957), que o descreveram como sendo a "soma total das operações de produção e distribuição de suprimentos agrícolas; das operações de produção na fazenda; do armazenamento, processamento e distribuição dos produtos agrícolas e itens produzidos à partir deles".

O conceito enfatiza a mudança nas interrelações entre o setor agrícola e o restante da economia.

Este conceito procura abarcar todos os vínculos intersetoriais existentes no setor agrícola deslocando o centro de análise de dentro para fora da fazenda, substituindo a análise parcial usualmente utilizada em estudos sobre economia agrária pela análise sistêmica da agricultura. Cabe ressaltar que a aferição das interrelações agricultura-indústria-serviços só aconteceu quando do desenvolvimento das técnicas de insumo-produto, através da matriz de relações intersetoriais especificada por LEONTIEE (1946).

No Brasil, a abordagem sistêmica de Davis e Goldeberg foi utilizada explicitamente por ARAÚJO et al. (1990), que realizaram um levantamento das dimensões básicas do Agribusiness Brasileiro, no seu todo e na decomposição dos seus agregados principais. As estimativas consolidadas pelos autores foram baseadas a partir de um conjunto de informações constantes dos censos econômicos, relatórios de produção e faturamento de setores industriais, dentre outros. Pelos dados de 1980, têm-se os seguintes valores expressos em bilhões de dólares, decompostos nos grandes elos da cadeia: o valor dos insumos e dos bens de produção para 
a agricultura foi de 8,5 bilhões de dólares ou 11,4\%; 0 valor dos bens produzidos pela agricultura atingiu 29,3 biIhões de dólares, assim distribuidos: produção vegetal 17,8 bilhões, produção animal - 11,5 bilhões, com uma participação de 27,8\% no valor adicionado; o setor de processamento alcançou 52,1 bilhões de dólares, com uma participação de 30,5\% no valor adicionado; e o setor de distribuição registrou um valor de produção de 74,7 bilhões de dólares, com uma participação de 30,3\% no valor adicionado. Desta forma, os negócios do Agribusiness Brasileiro representaram $46 \%$ dos gastos relativos ao consumo total das familias, correspondendo a uma magnitude equivalente a $32 \%$ do PIB brasileiro.

É importante destacar que os autores ao estudarem a evolução do Complexo Agroindustrial Brasileiro com relação a repartição de seu valor adicionado, verificaram uma mudança acentuada no período compreendido entre 1970 e 1980 (Tabela 2).

Tabela 2. Distribuição do valor adicionado entre os agregados no Complexo Agroindustrial brasileiro entre 1970 e 1980 .

\begin{tabular}{lcc}
\hline Agregado & \multicolumn{2}{c}{ Anos } \\
\hline I - Produção insumos agrícolas & 1970 & 1980 \\
II - Produção dos agricultores & $12 \%$ & $11,4 \%$ \\
III - Armazenagem, processamento, distribuição final, etc. & $38 \%$ & $27,8 \%$ \\
\hline
\end{tabular}

Fonte: ARAÚJO et al. (1990)

Malassis (1968), oriundo da Escola Francesa de Organização Industrial, também se empenhou em estudar o sis- 
tema agroindustrial, levando a cabo diversos trabalhos teóricos e empíricos dirigidos ao desenvolvimento do corpo conceitual e metodológico desse novo ramo da economia. Para esse autor há uma perspectiva histórica na análise do "Agribusiness", em que o Complexo Agroindustrial se constitui numa etapa do desenvolvimento capitalista onde a agricultura se industrializa.

Louis Malassis adota, ainda, uma ótica nova para analisar a inserção da agricultura no desenvolvimento econômico global. No primeiro momento, o autor examina a industrialização da agricultura e seus reflexos. No segundo momento, adota o conceito de complexo agrícola integrado, com o propósito de descrever e analisar os resultados dos processos de integração em nível micro-econômico. Assim, introduz a análise dos fluxos e encadeamentos por produto dentro de cada um desses subsetores, utilizando a abordagem de cadeia ou "filière" agroalimentar.

Define cadeia agroindustrial como a seqüência de ações físicas e o conjunto de agentes e operações envolvidos na obtenção de um produto agroalimentar ou agroindustrial (Malassis, 1968). Atreladas às cadeias agroindustriais estão as atividades correlatas como a pesquisa voltada à produção, os serviços financeiros, os serviços de transporte e de informação, como também os mecanismos de regulação (estrutura de funcionamento dos mercados, a intervenção do Estado, etc.).

Outro ponto fundamental, exposto tanto por Davis \& Goldberg como por Malassis é que com o desenvolvimento da agroindústria, a produção agrícola se organiza cada vez mais em grupos complexos e combinações agroalimentares. Se - grupo de "Agribusiness" se ocupou em estudar esta articu- 
lação em termos de eficiência econômica na integração vertical (em nível de agricultura, de empresas e grupos de empresas de transformação e de comercialização), a economia agroalimentar na interpretação francesa, e fundamentalmente de Malassis, se preocupou em demonstrar as relações de dominação da agricultura pela agroindústria e as transformações históricas da economia agroalimentar. ${ }^{9}$

É interessante a esse respeito a colocação de Silva (1991), de que a terminologia utilizada pelo grupo francês, embora seja marxista, incorpora basicamente a mesma linha dos pesquisadores norte-americanos, já citados, que conceituaram "Agribusiness", ou seja, os seus desciobramentos são sistêmicos, enfocando as relações de interdependência entre a agricultura e a indústria, exprimindo uma complementaridade entre as empresas capitalistas e os produtores rurais em relação a um produto dado. ${ }^{10}$

Müller (1989) define o CAI como "as relações entre indústria e agricultura na fase em que a agricultura apresenta intensas conexões para trás, com a indústria para a agricultura, e para frente, com as agroindústrias. O CAI é uma forma de unificação das relações interdepartamentais com os ciclos econômicos e as esferas de produção, distribuição e consumo, relações estas associadas às atividades agrárias". O autor introduz na análise uma série de infor-

9 MALASSIS \& PADILIA (1986) propõem uma classificação geral da economia da produção e consumo de alimentos, identificando quatro estágios: 1. Economia agroalimentar pre-agrícola; 2. Economia alimentar agricola e doméstica; 3. Economia alimentar agricola comercializada e diversificada; e, 4. Economia alimentar agro-industrial internacionalizada.

10 Esta revisão bibliográfica baseou-se, em grande parte, no extenso estudo sobre complexos agroindustriais desenvolvido por SILVA (1991). 
mações técnicas e econômicas, que apontam a intensificação da relação entre agricultura e indústria, com a crescente oligopolização dos setores industriais a montante e a jusante.

É importante notar que, na definição de Mülier, a modernização da agricultura é o resultado da interação entre industrialização do campo, agroindustrialização das atividades agrárias e mudanças sociais e politicas entre os grupos sociais. ${ }^{11}$ ou seja, a constituição do CAI é produto da modernização e a sua manutenção e expansão constituem-se no principal vetor da modernização. Cabe salientar que o autor enfatiza que a agricultura brasileira não pode ser vista como uma produção industrial "stricto sensu", mas sim como um movimento de industrialização. No Brasil não ocorreu o que se verificou em países centrais do capitalismo: a universalização da industrialização das atividades agrárias. Ou seja, houve a modernização de uma parcela da agricultura tradicional, com a manutenção de uma grande faixa atrasada (Tabela 3). A magnitude do setor agrícola dinâmico revela que a industrialização do campo foi parcial segundo regiões, produtos e tipos de produtores. Ademais, enfatiza a enorme participação do Estado no processo de incorporação das atividades agrárias à lógica da forma industrial de produzir e distribuir. Neste texto, Müller dá ênfase aos aspectos das mudanças e alterações de cunho sócio-político nas interrelações do agribusiness.

11 Industrialização do campo é definida como uma forte interdependência entre a agricultura e indústria para a agricultura; agroindustrialização é o processo em que ocorre forte interdependência entre agricultura e a indústria beneficiadora e processadora; e mudanças sociais referem-se às alterações nas relações de trabalho, basicamente. 
Tabela 3. Tipologia da Agricultura Brasileira.

\begin{tabular}{|c|c|c|c|c|c|c|c|}
\hline \multirow[b]{2}{*}{ Tipo 1} & \multirow[b]{2}{*}{ Tipo 2} & \multicolumn{2}{|c|}{ Agricultura (\%) } & \multicolumn{3}{|c|}{$\%$ do total } & \multirow[b]{2}{*}{ Ano } \\
\hline & & Atrasada & Dinâmica & Est. & Área & $\mathrm{VP}$ & \\
\hline \multirow{4}{*}{ (*) Grande e média empresa } & Grande & 76,0 & 24,0 & 0,6 & 39,6 & 12,6 & 1970 \\
\hline & $1.000 \mathrm{ha}+$ & 67,0 & 33,0 & 0,9 & 45,0 & 16,1 & 1980 \\
\hline & Médio & 78,0 & 22,0 & 15,4 & 45,0 & 39,6 & 1970 \\
\hline & $50-1000$ ha & 63,0 & 37,0 & 16,9 & 42,2 & 44,0 & 1980 \\
\hline \multirow[t]{2}{*}{$\left.{ }^{*}\right)$ Pequena empresa } & Pequeno & 83,0 & 17,0 & 32,3 & 12,3 & 29,9 & 1970 \\
\hline & $10-50$ ha & 68,0 & 32,0 & 31,5 & 10,1 & 16,7 & 1980 \\
\hline \multirow[t]{2}{*}{ (*) Minifúndio } & Micro & 91,0 & 9,0 & 50,6 & 3,1 & 17,9 & 1970 \\
\hline & Até 10 ha & 77,0 & 23,0 & 40,8 & 2,5 & 12,4 & 1980 \\
\hline
\end{tabular}

Fonte: MÜLLER (1989).

Obs.: Vide especificações no texto.

Agricultura dinâmica: o índice expressa a percentagem de estabelecimentos que tomaram empréstimos bancários para investimento e/ou custeio em relação ao total de estabelecimentos que declararam haver feito despesas (com mão-de-obra, insumos, juros); a agricultura atrasada é complementar à dinâmica.

Est.: percentual de estabelecimentos em relaçào ao total dos estabelecimentos recenseados. Área: área total ocupada pelos estabelecimentos recenseados.

VP: valor da produção total.

Para esse autor, a modernização da agricultura deve ser encarada como um processo geral que acelera e prepara a base do seu desenvolvimento capitalista, passando a predominar na atividade agrária a racionalidade empresarial. Esta postura difere grandemente da interpretação de Guimarães (1979), que considera a conexão agricultura/indústria e a conseqüente mudança da base técnica da produção agrícola, resultado de um desvirtuamento e numa apropriação indevida da indústria do lucro e da renda da terra dos agricultores.

Como salientado por Leite (1990), está presente em toda a análise de Müller o papel fundamental da indústria para a agricultura como elemento dinâmico do CAI. "A forma de difusão do progresso técnico na agricultura passa a depender não somente da diferença de preços relativos dos insumos dos mercados de fatores, como principalmente das inovações tecnológicas, introduzidas pelo setor a montante. É sobretudo este segmento que dá o caráter nacional às mu- 
danças na agricultura, por se tratar de unidades de capital oligopolizadas cuja estratégia de acumulação tem o mercado nacional como horizonte".

Eazemos aqui referência ao trabalho de Delgado (1985), que analisa o desenvolvimento agropecuário brasileiro, fazendo um corte histórico de 1960 a 1980, utilizando a abordagem de macro-complexo, em dois blocos analiticos, que enfatizam, num primeiro momento, os aspectos históricos desse processo recente e, no segundo momento, uma abordagem teórica, centrada na experiência brasileira, do desenvolvimento do capital financeiro na agricultura. O autor descreve um minucioso estudo sobre a evolução do setor rural, destacando os elementos de mudança significativa na estrutura econômica, as transformações que ocorreram na sociedade como um todo, enfocando o processo de urbanização, o comércio exterior agrícola, mudanças na base técnica de produção rural e a consolidação concomitante do sistema nacional de crédito rural, que leva a cabo o projeto de modernização agrícola.

Delgado corrobora o estudo de Müller (1989) no que se refere ao papel desempenhado pelo setor a montante no movimento de industrialização agrícola, identificando-o como o cerne da mudança na base técnica da produção rural que modifica efetivamente o processo produtivo. É deste ramo industrial que emanam as inovações que estão incorporadas aos novos meios de produção adotados. A ele se integra todo o aparato de pesquisa e extensão rural, formando o Departamento de Meios de Produção para a agricultura ( $\left.\mathrm{D}_{1}\right)$, que dirige tecnologicamente a modernização agrícola. Embora - ramo industrial a jusante (indústria processadora de alimentos e matérias-primas) também induza a mudanças nas téc- 
nicas de produção agrícola, no que se refere a tipos de produto, exigências sanitárias, qualidade e homogeneidade da matéria-prima, regularidade de sua entrega, impondo um perfil tecnológico à produção que deve ser seguido pelos agricultores, por si só, essas exigências não são suficientes para induzir em geral o movimento de alteração da base técnica de produção.

Da rica análise realizada por Delgado, queremos destacar o fato de sua análise fundamentar-se na integração de capitais e não na integração técnico-produtiva. Concebe a integração técnica como um momento do processo mais geral de integração de capitais ou de fusão de capitais múltiplos em conglomerados, operantes também no setor rural. Segundo o autor, "... o processo de integração de capitais na agricultura brasileira revela a presença de uma nova estratégia do grande capital na agricultura e é o que distingue a constituição do CAI e não a integração das atividades agrárias numa cadeia produtiva. A agricultura passa a se constituir num ramo da indústria onde ocorre grandes aplicações de capitais. Esse capital financeiro organiza a aplicação dos excedentes financeiros da sociedade, tendo como primordial objetivo uma taxa média de lucro do conjunto de atividades e mercados onde opera. Entre as formas citadas pelo estudo de como se dá o processo de integração de capitais tem-se: as grandes sociedades anônimas e grupos econômicos, organizados sob a forma de "holdings", "empresas de participação e administração", "bancos de investimento", "multicooperativas" e grandes atacadistas. Outra linha de integração é a disseminação dos chamados contratos formais ou acordos informais de quase-integração entre a grande agroindústria e os pequenos e médios produtores rurais". 
Para Delgado (1985), o CAI brasileiro está atrelado ao Estado, que desempenha funções patrocinadora, financiadora ou reguladora. "Essa dominação crescente da regulação estatal, através de seus aparatos de politica agrícola, possibilita a captura de margens diferenciais de lucro e ganhos extraordinários por parte dos capitais que se integram, ou mais profundamente organizam-se como conglomerados na agricultura". É importante perceber que, para o autor, o eixo de articulação fundamental do Estado é a regulação financeira, administrando os financiamentos, redirecionando os capitais para os diversos ramos através de mecanismos monetários-financeiros, de penalizações e incentivos fiscais.

O trabalho de Eonseca (1987), citado por Leite (1990), detalha um pouco mais os aspectos ligados as inovações tecnológicas na agricultura, colocando o setor rural como o segmento demandante de inovações de fornecedores especializados e "science based", e identificando como a fonte de geração de nova tecnologia o setor produtor de bens de produção para a agricultura (máquinas e implementos) e o setor químico, concluindo que estes ramos determinam uma trajetória que reflete decisivamente nos demais setores formadores do CAI.

Estudo do Banco Nacional de Desenvolvimento Econômico e Social (BNDES), coordenado por Ramalho (1988), teve por objetivo analisar a lógica de crescimento do setor agropecuário e identificar os núcleos pressionadores de seu dinamismo, onde a abordagem escolhida foi a do complexo Agroindustrial.

O trabalho constata a importância do progresso tecnológico no desenvolvimento do CAI e na definição adotada através da qual os autores consideram o setor fornecedor 
para a agropecuária formado basicamente pelas indústrias produtoras de bens de capital e a indústria química, que desempenham o papel de núcleo gerador do progresso técnico do CAI, modernizando-o e proporcionando um aumento de produtividade. O setor agropecuário é visto como sendo o segmento dominado tecnologicamente pelos fornecedores de máquinas, equipamentos e insumos que promovem as inovações. Por sua vez, a viabilização da introdução do progresso técnico fica a cargo da agroindústria e da indústria de alimentos através da pressão que exercem sobre os produtores, estabelecendo suas compras com base na escala produtiva, nas especificações e nos custos da matéria-prima, promovendo uma adequação da forma de organização da produção deste setor aos requisitos que viabilizam a introdução do padrão tecnológico.

Lauschner (1993) valendo-se dos conceitos desenvolvidos por Davis \& Goldberg (1957) e denominando-os de complexo rural, procura analisar o que significa no contexto da agricultura o complexo rural, a agroindústria e o futuro da estrutura fundiária das explorações rurais. A questão central do trabalho é analisar se a grande empresa pode ser benéfica para o pequeno produtor se ela for agroindústria, procurando através da análise de insumo-produto verificar a importância da agroindústria como agente de geração de renda e emprego.

Embora Lauschner considere conveniente, para a análise da problemática rural, a visão sistêmica de complexo rural (ou "Agribusiness") centraliza sua análise no segmento de transformação e processamento agropecuário, reconhecendo que essa abordagem não dá conta de entender a dinâmica do setor. Argumenta que "as decisões do complexo rural situam-se cada vez mais ao nível dos que transformam 
os produtos rurais, ou seja, ao nível dos gestores das agroindústrias, decorrendo que o setor motriz do complexo é dado pela agroindústria, que transforma a agricultura cada vez mais em uma economia de uso de capital intensivo". E conclui que "a agroindústria é o agente econômico que pode oferecer o melhor apoio aos produtores, como forma de agregar valor, ampliar a renda e o emprego rural, dinamizar as pequenas cidades, fortalecer a economia frente ao exterior e como instituição de apoio direto das explorações rurais". o autor ainda conclui que "... a agroindústria cooperativa é o modelo ideal de organização e de auto-promoção do pequeno produtor rural".

É preciso destacar que quando se estuda a agroindústria dentro de uma visão sistêmica, um dos problemas metodológicos que surgem é referente a sua delimitação. Amaro et al.(1987) baseando-se em conceituações de alguns organismos internacionais, entre eles a FAO (Food of Agriculture Organization), BID (Banco Interamericano de Desenvolvimento) e ONUDI (Organizações das Nações Unidas para $\bigcirc$ Desenvolvimento Industrial) sobre a agroindústria apresenta a seguinte definição: "no Complexo Agroindustrial a agroindústria é a unidade produtora integrante dos segmentos funcionalmente localizados nos níveis de suprimentos à produção (indústria a montante), transformação e acondicionamento, e que transforma o produto agrícola, em primeira ou segunda transformação, para a sua utilização intermediária ou final". Uma limitação dessa conceituação reside no fato de abarcar ramos extremamente heterogêneos como indústria têxteis, indústria de madeira, padarias, etc. 
A FUNDAÇÃO SEADE - Sistema Estadual de Análise de Dados (1990), em seu trabalho sobre a agroindústria paulista, que teve como principais objetivos, analisar as causas do desenvolvimento recente da agroindústria no Estado de São Paulo, sua localização e concentração, considera a agroindústria como o setor que realiza o beneficiamento dos produtos agrícolas em sua primeira fase, não computando os produtos agrícolas em sua fase final.

Por sua vez, Lauschner (1993), mediante critérios especificos, diferencia as agroindústrias em sentido amplo e restrito. O conceito de agroindústria em sentido amplo "refere-se a unidade produtiva que transforma o produto agropecuário natural ou manufaturado para utilização intermediária ou final". Considera a agroindústria em sentido restrito como sendo "a unidade produtiva que, por um lado, transforma, para a utilização intermediária ou final, o produto agropecuário ou seus subprodutos não manufaturados; e que, por outro lado, adquire diretamente do produtor rural o mínimo de $25 \%$ do valor total dos insumos utilizados". Assim, a agroindústria em sentido restrito engloba o setor de transformação dos produtos rurais mais próximo à produção rural, não no que tange ao espaço geográfico mas em relação ao grau de participação dos insumos no processo produtivo. Na definição restrita o autor exclui as indústrias que utilizam como matéria-prima o produto agropecuário já transformado, não considerando, por exemplo, a indústria têxtil, a indústria de calçados, indústrias de massa e biscoito, por serem segmentos industriais que utilizam como matéria-prima um produto rural já industrializado e a parcela de insumos que adquirem diretamente do setor produtivo rural é insignificante quando não nula. 
No entanto, tanto a distinção entre processar e beneficiar quanto a separação feita por Lauschner entre agroindústria ampla e restrita levam a uma restrição conceitual grande, uma vez que só consideram a agricultura industrializada (Müller, 1989).

Müller (1989) reconhece que a distinção entre transformar e beneficiar é fundamental no estudo de cadeias agroalimentares mas questiona esta segmentação no âmbito da agroindústria, julgando tão relevante a mudança radical na forma do valor de uso quanto seu beneficiamento e conservação. Ressalta que o mais importante é o porte e a concentração tecnoeconômica dos capitais investidos nos ramos agroindustriais como também a distinção entre as formas de produzir.

O autor reconhece que ao se estipular $25 \%$ do valor total dos insumos utilizados na transformação objetiva-se operacionalizar o conceito e delimitá-lo. Mas argumenta que este índice além de ficar na dependência dos preços relativos, uma magnitude diminuta do mesmo pode estar dizendo pouco sobre seu impacto na agricultura. Como exemplo, cita os casos das indústrias de papel e papelão e borracha. Conclui ser um corte que deverá ser feito "ad-hoc", para fins específicos, dependendo do que se quer enfatizar lagricultura, indústria) e do nível de agregação.

Um outro ponto citado por Müller que adquire relevância para a agricultura brasileira é que os setores industriais fornecedores para a agricultura abastecem com suas produções tanto os segmentos agrícolas que produzem matérias-primas, como soja, trigo, como os segmentos produtores de bens "in natura", como o arroz, feijão, hortifrutigranjeiros, que representam um mercado altamente significativo. Desta forma conclui que, na análise do CAI, 
a conceituação de agroindústria no sentido restrito deve ser vista com cautela, uma vez que há fluxos associados à industrialização do campo que não passam pela transformação.

Por sua vez, Delgado (1985) define o grupo de indústrias a jusante, componente do Complexo Agroindustrial, usando os critérios de origem agropecuária das matériasprimas utilizadas e estabelecendo o limite inferior de 50\% de sua participação no valor da produção industrial. Além disso, faz uma classificação de ramos industriais neste segmento composto de: produtos alimentares; química; fumo; madeiras; mobiliário; couros e peles; bebidas; têxtil; papel e papelão.

Essa ambigüidade que o conceito CAI apresenta ainda não está definitivamente equacionada, havendo bastante controvérsia, e provocando dificuldades metodológicas e operacionais. Contudo, não se pode esquecer das limitações provenientes da forma como as estatísticas nacionais são computadas.

No caso de Ramalho (1988), as indústrias compradoras de matérias-primas agropecuárias foram tratadas em duas categorias - a agroindústria e a indústria de alimentos. O argumento do autor é o de que a distinção entre esses dois ramos deve-se a lógicas concorrenciais distintas (diferenciação do produto, economia de escala) que poderão influenciar de forma diferenciada o setor agropecuário.

Para Ramalho (1988) "a agroindústria é caracterizada como sendo o primeiro processamento da matéria-prima oriunda do setor agropecuáric. Seus produtos são homogêneos tendo como mercado a exportação e outras indústrias. Os principais ramos formadores da agroindústria são: açúcar e 
álcool, moinho de trigo, óleos vegetais e suco de laranja. As lógicas concorrenciais adotadas são semelhantes, independente do segmento de atuação, o que permite tratá-los de uma forma agregada. A maior parte desses produtos são "commodities" tendo seus preços definidos no mercado internacional. A influência que exerce sobre o setor agropecuário é no sentido de obter grandes lotes de produção e a custos compativeis com $\circ$ processamento agroindustrial. Grande parte das empresas agroindustriais atua também na indústria de alimentos, verticalizando-se, já que seu porte financeiro e a dimensão do mercado conferem capacidade competitiva para atuação conjunta nos dois ramos de atividade, - que faz com que no Brasil a separação entre agroindústria e a indústria de alimentos não seja tão nítida. A indústria de alimentos tanto pode executar o processamento da matéria-prima adquirida do produtor rural como o da obtida da agroindústria. O que a diferencia da agroindústria é o fato de estabelecer uma relação com o consumidor final, conferindo-lhe estratégias de comercialização mais elaboradas. Da mesma forma que na agroindústria, a estrutura da indústria de alimentos pode ser melhor visualizada se segmentada. Também, para esse setor as estratégias concorrenciais são muito semelhantes em todos os subsetores". Neste trabalho, a estrutura das indústrias de alimentos foi dividida em: massas, café solúvel, torrefações, laticínios, conservas, frigorificos e diversos.

Especificamente, em relação a afirmação do autor de lógicas concorrenciais semelhantes, cabe lembrar sempre que há uma "falsa" homogeneidade do processo de produção de "commodities" pois na verdade são ramos distintos, como por exemplo, pecuária, soja e outros, com formas de concorrên- 
cias particulares e processos de formações de preços peculiares a cada mercado.

"No Brasil, a produção de vários segmentos da indústria de alimentos é descentralizada, com participações de pequenas e médias unidades localizadas nas proximidades das zonas de produção agrícola. No entanto, o capital, a propriedade ou o controle do mesmo é concentrado. A diferenciação de produtos tem sido a principal forma de expansão da indústria alimentar, que muitas vezes se restringe a alterações de embalagens, não ocorrendo modificações na composição. A procura de novos campos de valorização do capital, depois de esgotados os produtos tradicionais de cada empresa, leva-a a investir pesadamente em novos campos, desenvolvendo novos produtos. Esse perfil de administração tem reflexos na estrutura de consumo alimentar da populaÇão, modificando-a e incorporando novos hábitos alimentares. A produção agropecuária não fica imune a esse processo, tendo de se adequar ao novo tipo de demanda criada pela indústria de processamento alimentar" (Ramalho, $1988)$.

O fundamental a ressaltar é que, independentemente da conceituação adotada para agroindústria, há um consenso entre os analistas econômicos de que o desenvolvimento agroindustrial é o caminho mais eficiente de um país adicionar valor sobre o produto agrícola produzido (Goldberg, 1957; Lauschner, 1993). O desenvolvimento do CAI propicia novos mercados que possibilitam, além da ampliação da exportação, gerar rendas e impostos para o país.

Sorj (1980), utilizando também uma perspectiva intersetorial, realiza um trabalho com o objetivo de caracterizar as transformações ao nível da estrutura de classes e do papel desempenhado pelo Estado. O trabalho focaliza o 
ciclo histórico de expansão agroindustrial brasileiro, e apresenta uma série de dados que corrobora a intensidade das relações entre agricultura/indústria, sobrepujando os interesses industriais, apoiados pelas políticas de Estado. Analisa, também, a estrutura do Complexo Agroindustrial e as diferentes formas de inserção da produção agrícola, englobando no exame desde 0 setor $D_{1}$ (indústria de insumos para a agricultura) até o setor de supermercados. O autor apresenta a seguinte conceituação para Complexo Agroindustrial: "conjunto formado pelos setores produtores de insumos e maquinarias agrícolas, de transformação industrial dos produtos agropecuários e de distribuição, e de comercialização e financiamento nas diversas fases do circuito agroindustrial".

Para Sorj "... a integração da agricultura com a indústria remonta às origens da colonização do Brasil, onde a produção agrícola de exportação já era processada internamente. Entretanto, a agroindústria fornecedora de insumos e bens de capital para o setor agrícola assim como o segmento de processamento de alimentos em grande escala para o mercado interno podem ser visualizados como um acontecimento contemporâneo. Atuaram, concomitantemente, os níveis crescentes de acumulação de capital, a expansão do mercado urbano e o próprio crescimento da agricultura, para a utilização crescente de tecnologia avançada". O surgimento do Complexo Agroindustrial só foi possibilitado, na opinião do autor, pelo desenvolvimento agrícola anterior e se transformou no maior acelerador das transformações na agricultura. As características presentes no CAI são: alto grau de concentração do capital, concorrência oligopólica, presença de recursos estrangeiros e nacionais. 
Farina (1988) formula o conceito de Sistema Agroindustrial de alimentos objetivando uma abordagem sistêmica, mas privilegiando o setor alimentar, ancorado nos estudos de organização industrial. Para tal, denomina sistema Agroindustrial de Alimentos (SAA), "a cadeia que se inicia na produção agrícola de culturas alimentares, passa pelo processo de transformação industrial e através da rede de distribuição chega ao consumidor final. O perfil e complexidade de tal sistema estão diretamente associados ao grau de desenvolvimento econômico do país e o elo industrial será tão mais importante quanto mais avançado o processo de industrialização e urbanização" .

No que tange a contribuição do sistema alimentar para a formação do Produto Interno Bruto Brasileiro, a autora calcula, através dos dados dos Censos Comercial, Agrícola e Industrial, a sua participação em 1980, chegando aos seguintes resultados: o sistema agroindustrial de alimentos responde por $17 \%$ do PIB, com a agricultura, a atividade industrial e a distribuição, contribuindo com 72\%, $20 \%$ e $8 \%$, respectivamente, no valor de produção (Tabela 4).

Tabela 4. Contribuição do Sistema Alimentar para o PIB. 1980.

\begin{tabular}{|c|c|c|c|}
\hline & $\begin{array}{c}\text { № DE ESTA- }^{0} \text { DELECIMENTOS } \\
\text { BELE }\end{array}$ & $\begin{array}{c}\text { VALOR } \\
\text { ADICIONADO } \\
\text { (Cz\$ mil })\end{array}$ & $\begin{array}{c}\text { PARTICIPAÇÃO NO } \\
\text { SISTEMA ALIMENTAR } \\
\%\end{array}$ \\
\hline 1. Agricultura (V.P.) & & 1.430 .181 .770 & 72 \\
\hline 2. Ind. Alimentar (V.T.I.) & & & \\
\hline Alimentos & 48.876 & 372.940 .358 & 19 \\
\hline Rações & 490 & 21.818 .733 & 1 \\
\hline TOTAL & 49.366 & 394.759 .091 & 20 \\
\hline 3. Distribuição (V.A.) & & & \\
\hline Atacado & & 34.249 .962 & 2 \\
\hline Varejo & & 125.302 .537 & 6 \\
\hline TOTAL & & 159.552 .499 & $\overline{8}$ \\
\hline $\operatorname{TOTAL}(1+2+3)$ & & 1.984 .493 .360 & \\
\hline$\%$ PIB & & $17 \%$ & 100 \\
\hline
\end{tabular}

Fonte: FARINA (1988)

PIB-80 = 11.929.648.800 (Cr\$ mil $)$ 
Em que pese as diferenças metodológicas dos diferentes trabalhos e que levam a resultados diferentes, devese observar que Farina trabalha com Valor de Produção para a agricultura e Valor de Transformação Industrial para a indústria alimentar. Cabe ressaltar que a forma de cálculo utilizada leva a uma superestimativa da importância do setor agrícola, na medida em que não desconta o valor dos insumos industriais, o que é salientado pela própria autora. No que se refere ao ramo industrial não inclui as indústrias ofertantes de insumos e de bens de capital para a agricultura, além de focalizar somente as indústrias alimentares.

Embora a análise trate o Sistema Agroindustrial de Alimentos como um todo, a premissa básica é de que "o segmento industrial que define sua dinâmica, onde a indústria de transformação é um segmento chave nesse sistema, respondendo pela composição do "design" dos produtos, principalmente os menos tradicionais, que cada vez mais são incorporados na cesta alimentar da população. Salienta, também, o fato da indústria transportar, estocar e tornar menos perecíveis os alimentos. Particularmente, admite-se que o comando de direção é articulado pelas grandes empresas nacionais e estrangeiras responsáveis por novas técnicas que permitem uma sincronização dos fluxos de produção no mercado, diferenciando-a das outras indústrias de bens de consumo pelo fato de utilizarem insumos agrícolas. A autora adota a teoria do crescimento da firma onde as unidades básicas de análise são as firmas e as estruturas. Dada as peculiaridades do crescimento da indústria de alimentos (crescimento da renda e do emprego), as inovações concentram-se na diversificação dos produtos alimentares finais, numa clara utilização de estratégias de mercado. É 
importante ressaltar que Farina aponta entre outras falhas, na metodologia usual do CAI, a não consideração na análise das estratégias concorrenciais".

Streeter et al. (1991), citado por Santana (1994), seguem a mesma lógica de Farina, abarcando na visão ampla do Complexo Agroindustrial (CAI), somando à cadeia retrospectiva e prospectiva, o consumidor, como agente influente na localicação dos nichos de mercados. A Figura 1 apresenta esquematicamente tal processo, onde o "Agribusiness" é visto como um encadeamento de atividades inter-relacionadas, compostas pelas empresas fornecedoras de insumos para a agricultura, a produção agrícola, as atividades de armazenamento, distribuição, processamento e os consumidores. Integrando esses segmentos e oferecendo uma estrutura de apoio, visualiza-se as firmas e o governo, atuando na área de serviços, financiamentos e pesquisa/desenvolvimento. Streeter e seus colaboradores reconhecem a importância crescente do comportamento do consumidor, que passa a atuar decisivamente no desenvolvimento do CAI e salientam o esforço do setor varejista de comercialização no atendimento dos gostos e preferências do consumidor, no sentido de adequá-los aos sinais da demanda. Nesta visão, os produtos trarão inseridos uma gama de serviços deles indissociáveis e refletirão um novo perfil de demanda. O consumo de alimentos passa a ser analisado por uma ótica que abrange critérios de saúde, além dos nutricionais (proteína e energia), como também aumentam os padrões de exigências quanto à qualidade e diversificação de produtos dos consumidores. Neste cenário, a pesquisa e o desenvolvimento tecnológico tem contribuido decisivamente para o aperfeiçoamento do processo de comercialização, no que se refere às preferências do consumidor e também no fortaleci- 


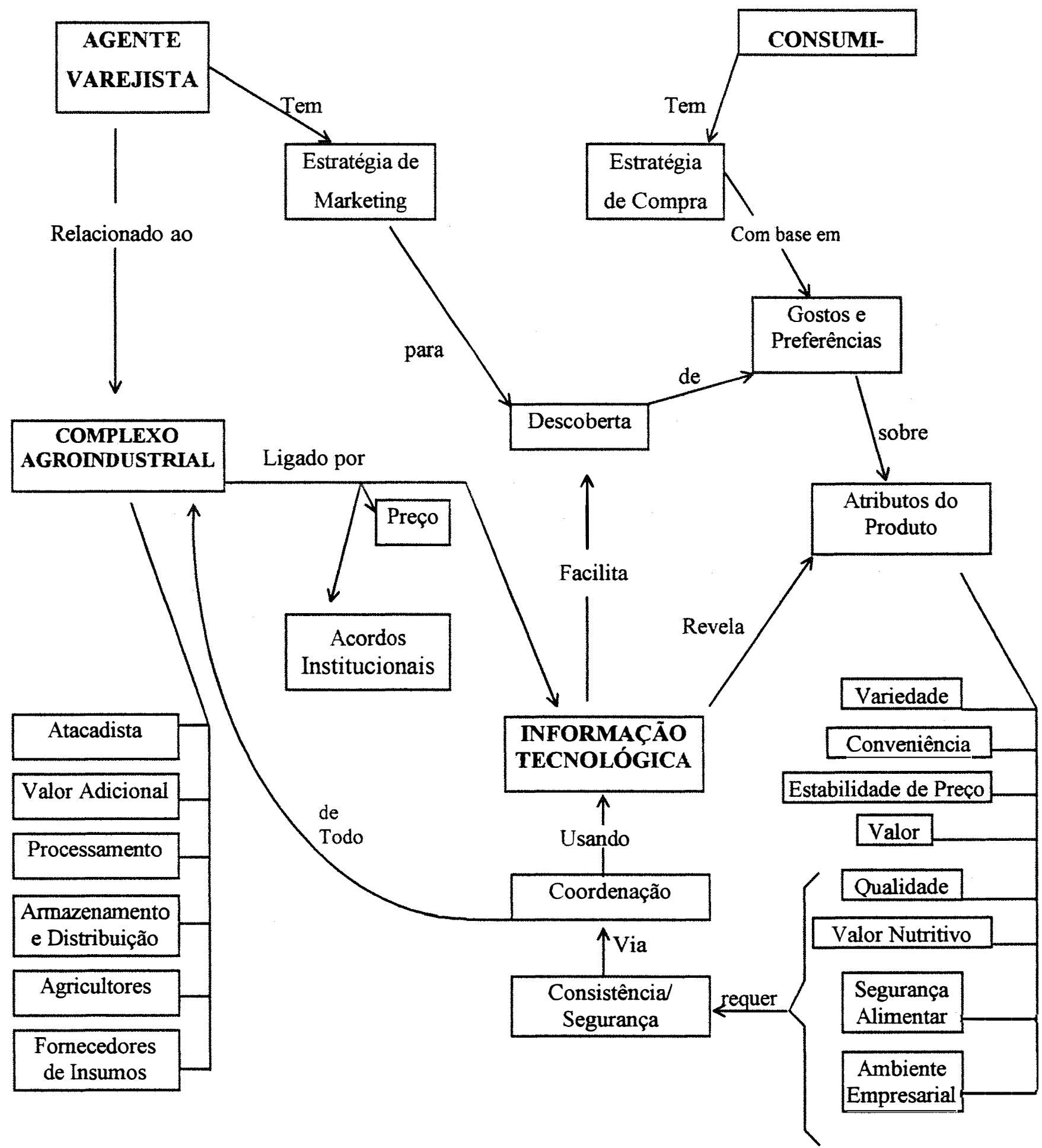

Fonte: STREETER et al. (1991), citado por SANTANA (1994).

Figura 1. Estrutura Representativa da Dinâmica e da Coordenação de Atividades do Complexo Agroindustrial. 
mento das ligações de produção, dentro do agribusiness. Concluem os autores que "o mercado é a força motora que coordena e imprime a dinâmica competitiva do complexo agroindutrial".

O estudo extenso e detalhado de Santana (1994) apresenta uma análise em que o objetivo é avaliar, sob vários cenários de política econômica, os impactos que a expansão do CAI brasileiro exerce sobre a produção, o emprego e a distribuição da renda em toda economia.

Utiliza o conceito de "macroeconomic linkage", para estimar as influências das diferentes politicas econômicas sobre as relações intersetoriais. Como modelo empírico faz uso da estrutura de equilíbrio geral da economia brasileira, através da matriz de contabilidade social, e interpretada por meio da análise dos multiplicadores e da estrutura de passos da economia. Para tal utiliza dados de 1975 e 1985 .

Entre os resultados obtidos ressalta-se os referentes a análise dos multiplicadores globais que mostra forte dependência intersetorial entre as atividades do CAI e destas com toda economia. As análises de interdependência econômica e de estrutura de passos mostram que as atividades do CAI apresentam as maiores "linkages" para frente e/ou para trás, como também os melhores canais para a transmissão dos efeitos, na estrutura da economia brasileira, indicando ser este bloco de atividades especialmente importante, para receber estímulos visando um crescimento sustentado.

Earina \& Zylberstajn (1992), em resenha em que debatem o Sistema Agroindustrial Brasileiro, analisam as diferentes formas pelas quais os diferentes segmentos componentes do sistema se interrelacionam para garantir seu 
processo de acumulação. Essas ligações podem assumir a forma de uma completa integração vertical, relações impessoais de mercado por meio de sistema de preços, ou podem dar-se através de contratos formais e informais.

Os autores reconhecem que a visão sistêmica contém elevado grau de abstração, uma vez que as cadeias produtivas apresentam heterogeneidade na dinâmica, organização e desempenho, o que leva a que a análise através das cadeias agroindustriais expressem melhor as relações comerciais e tecnológicas presentes nos diferentes setores. Entretanto, consideram que a "cadeia produtiva pode ser definida como um recorte dentro do complexo agroindutrial mais amplo privilegiando as relações entre agropecuária, indústria de transformação e distribuição, em torno de um produto específico (frango, leite, laranja, etc.)".

Outra tendência deste artigo é o de sustentar um novo padrão de crescimento para o sistema agroindustrial, voltado para a crescente diversidade de produtos, onde o papel do consumidor é decisivo no sentido de exercer, cada vez mais, seu poder de compra de forma a orientar as estratégias empresariais. Assim, o mercado consumidor pode ratificar ou rejeitar as estratégias de crescimento das empresas, e a crescente organização, informação e conscientização dos consumidores tem alterado o "super ambiente"12 em que as empresas industriais operam, condicionando suas estratégias competitivas.

Em suma, a relevância da análise sistêmica do "agribusiness" já é amplamente disseminada na literatura

12 "Superambiente" é definido, pelos autores, como um conjunto de fatores externos à empresa, e que dificilmente são afetados por suas estratégias de crescimento. 
brasileira onde há um crescente reconhecimento da importância de uma perspectiva intersetorial na economia agrícola em substituição aos enfoques tradicionais de análise econômica que utilizam a ótica de setores primário - secundário - terciário na economia. Sendo assim, o conceito analítico de "agribusiness" se afigura como unidade de análise adequada para se estudar a dinâmica da agricultura considerando as múltiplas relações do setor rural com a indústria e os correspondentes mercados.

Para finalizar percebe-se que quando se estuda a agricultura dentro de uma visão global um dos problemas que surgem é referente a noção de complexo a ser adotada. Trata-se de uma conceituação que depende do que se quer enfatizar.

Neste trabalho adota-se a denominação de Complexo Agroindustrial (CAI) por considerar o termo mais abrangente e por precisar melhor o uso analítico que se propõe. O Complexo Agroindustrial, CAI, representará um conjunto formado por: a) setores industriais que fornecem bens e serviços para a agricultura, que denominaremos de Indústria Para a Agricultura; b) a agricultura propriamente dita; c) setores industriais que têm na agricultura seus mercados fornecedores, que denominaremos de Indústria de Base Agrícola; e d) o Setor de Distribuição, que englobará os segmentos de transporte, comércio e serviços $(0$ procedimento adotado para o delineamento do CAI e sua composição estão descritos na seção 3.3 e 4.2 , respectivamente). 


\section{REFERENCIAL TEÓRICO}

\subsection{Fontes e Tratamento das Informações Básicas}

Para efeito desse trabalho utilizam-se as informações provenientes das Matrizes de Insumo-Produto calculadas oficialmente pelo IBGE correspondentes ao período de 1980 a 1994. Vale mencionar que se trata das últimas informações disponíveis na matéria apresentando, assim, o máximo grau de atualidade possível.

A elaboração de Matrizes Insumo-Produto é feita a partir dos trabalhos de Contas Nacionais, através do modelo de Leontief, com periodicidade qüinqüenal até 1990, e anual a seguir, cobrindo todas as atividades econômicas, em nível de Brasil.

Tendo em vista o objetivo do presente trabalho, de quantificação do PIB do Complexo Agroindustrial, a Matriz de Insumo-Produto é o instrumento adequado para esse fim, uma vez que a análise dos fluxos de bens e serviços na economia e dos aspectos básicos do processo de produção estrutura de produção e de insumos das atividades, assim como a geração primária da renda (Salários, Encargos Sociais e demais Rendimentos do trabalho; Excedente Operacional Bruto das Atividades Econômicas; Impostos e Subsidios sobre as Atividades Econômicas) - são os principais objetos das Tabelas de Insumo-Produto. 
A escolha deste corte temporal deve-se basicamente a disponibilidade de dados e permite perfeitamente identificar a evolução dos fenômenos relacionados com às Atividades Produtivas da nação.

Segundo FIBGE (1988), a Matriz de Insumo-Produto de 1980 já faz parte fundamental do Novo Sistema de Contas Nacionais (NSCN) do IBGE e apresenta alterações metodológicas em relação às matrizes anteriormente publicadas, 1970 e 1975, principalmente no que diz respeito ao conceito de produção. Em 1980, utilizou-se um conceito amplo de produção com o intuito de englobar, por exemplo, a parcela da economia não computada nos censos econômicos. O tratamento dos dados básicos se encontra no texto Novo Sistema de Contas Nacionais - Metodologia e Resultados Provisórios - Ano-Base 1980 - volume I - nㅇ 10 - dez. 1988 - DPE.

O princípio básico adotado pelo IBGE na definição do processo de produção é o de considerar "a unidade produtiva, o estabelecimento (local físico) onde se realiza uma única atividade econômica. As atividades são formadas agregando-se os estabelecimentos com estruturas relativamente homogêneas de consumo e produção. É levado em conta que as unidades produtivas podem produzir produtos típicos de outras atividades; os estabelecimentos são classificados pela produção principal, resultando assim uma produção secundária de produtos não representativos de sua atividade" (FIBGE, 1988).

Segundo o IBGE, a construção da classificação de atividades nas Tabelas de Insumo-Produto é feita baseada no conjunto de estabelecimentos já classificados nos censos 
econômicos e inquéritos especiais, e adota critérios de homogeneidade quanto a mercados (destino de bens e serviços produzidos) e tecnologia (semelhança de insumos ou processos de produçãol. Em relação aos bens e serviços, são reunidos considerando-se a homogeneidade quanto à origem atividade produtora e procedência nacional ou importada e ao destino - tipo de consumidor elou usos específicos dentro de cada grupo.

A Matriz de 1985 e dos anos 90 foram preparadas, também, conseqüentemente, em conformidade com os conceitos e classificações adotados nas Contas Nacionais. Entretanto, foram elaboradas num nível de agregação maior - 42 atividades e 80 produtos - do que a matriz de 1980 - 88 atividades e 136 produtos, o que traz algumas limitações à análise pretendida referentes, principalmente, a delimitação das indústrias componentes do Complexo Agroindustrial.

A compatibilização das classificações das Matrizes de 1980 e 1985-90 é apresentada no apêndice 1. As classificações listadas englobam a classificação de produtos e atividades propriamente dita e seus respectivos códigos. ${ }^{13}$

Considerando os objetivos desta análise e as limitações das próprias informações básicas, optou-se por ajustar os dados setoriais mantendo a agregação original de 42 setores e 80 produtos das estimativas de 85-90. Um nível maior de agregação implicaria na soma de atividades muito

13 A metodologia para agregação dos setores e produtos segue 0 apresentado no capitulo 5 de Miller \& Blair (1985). 
heterogêneas afetando a qualidade da análise. Os dados disponíveis têm a sua apresentação numa abordagem do tipo produto por setor, permitindo que cada produto seja produzido por mais de um setor e que cada setor produza mais de um produto, ou seja, a matriz de produção e a matriz de insumos devem ser combinadas gerando o enfoque de Leontief (setor $x$ setor) conforme descritos por Miller \& Blair (1985).

\subsection{Estrutura produtiva, setores-chave, e ligações interindustriais}

Visando o delineamento do Complexo Agroindustrial realiza-se a análise da estrutura produtiva e dos setoreschave que nos permite visualizar a economia em questão e em especial os setores agrícola e agroindustriais.

Procede-se ao exame da estrutura produtiva brasileira através de um conjunto de informações básicas contidas nas tabelas de insumo-produto, para os anos 1980, 1985, 1990 (FIBGE, 1989, 1990, 1996), enfocando níveis de produção setorial, de participação da demanda final na produção total e de participação das importações e dos salários no total dos insumos utilizados no processo produtivo. ${ }^{14}$

A identificação de setores-chave passa necessariamente pela definição de índices de ligações interindustriais. Neste campo existem recentes metodologias para estimativas de ligações, mais consistentes matematicamente. Os novos métodos de medição possibilitam

14 Ver SYRQUIN (1988) sobre a abordagem teórica da análise de estruturas produtivas através de matrizes de insumo-produto. 
uma visão mais ampla da economia, mas não substituem as abordagens tradicionais, uma vez que os vários procedimentos são complementares entre si. ${ }^{15}$

Os multiplicadores setoriais fornecem informações que permitem determinar o impacto de diferentes estratégias setoriais sobre variáveis econômicas, resultados que não são captados pela análise da estrutura produtiva e de setores-chave.

Essas análises permitem visualizar a economia em questão e inferir como se comporta frente às políticas setoriais.

\subsubsection{Os índices de Rasmussen-Hirschman}

Segundo Leontief (1951), os fluxos intersetoriais, em uma dada economia, podem ser determinados por fatores econômicos e tecnológicos a partir de um sistema de equações simultâneas, da forma:

$$
X=A X+Y
$$

onde $X$ é um vetor ( $n \times 1)$ que denota o valor da produção total por setor; $Y$ é um vetor $(n \times 1)$ do valor da demanda final setorial; $e A$ representa a matriz $\left(\begin{array}{lll}n & n\end{array}\right)$ dos coeficientes técnicos de produção, isto é, a matriz de coeficientes diretos de insumos de ordem ( $n \times n)$. Neste modelo, o vetor de demanda final é geralmente tratado como exógeno, assim o vetor de produção total é determinado apenas pelo vetor de demanda final:

15 Para una discussão do conceito de setores-chave, ver Guilhotto, Sonis, Hewings e Martins, 1994. 


$$
X=B Y
$$

$$
B=(I-A)^{-1}
$$

onde $B$ representa a matriz de insumos diretos e indiretos $(\boldsymbol{n} \times \boldsymbol{n})$, ou a matriz de Leontief.

Em $B=(I-A)^{-1}$, o elemento $b_{i j}$ deve ser interpretado como sendo a produção total do setor $i$ que é necessária para produzir uma unidade de demanda final do setor $j$.

A partir da equação (3) pode-se obter os valores dos multiplicadores de produção do tipo I (Ver Miller e Blair, 1985) que correspondem à soma das colunas da matriz $B$. Tais multiplicadores fornecem informações a respeito do aumento, em unidades, do produto total causado pelo aumento de uma unidade na demanda final do produto de um setor, dada as ligações intersetoriais na economia.

A partir deste modelo, é possivel calcular os Índices de Iigações para Frente e para Trás, ou Índices de Rasmussen-Hirschman, que permitem determinar os setores que mais contribuem para o desenvolvimento da economia. Os setores que apresentam esses índices maiores que a unidade são considerados setores-chave.

Os indices de Ligações para Trás (poder da dispersão) e para Frente (sensibilidade da dispersão) são determinados, respectivamente, através das expressões:

$$
\begin{aligned}
& U_{j}=\left[B_{* j} / n\right] / B^{*} \\
& U_{i}=\left[B_{i *} / n\right] / B^{*}
\end{aligned}
$$

onde define-se $b_{i j}$ como sendo um elemento da matriz inversa de Leontief $B ; B^{*}$ como sendo a média de todos os elementos 
de $B_{i} B_{* j}$ e $B_{i *}$ como sendo, respectivamente, a soma de uma coluna e de uma linha típica de $B$; e $n$ o número de setores na economia.

O Índice de Ligações para Trás denota o quanto um setor demanda dos outros setores, enquanto 0 Índice de Ligações para Frente denota o quanto um setor é demandado pelos outros.

O Índice de Dispersão (Bulmer-Thomas, 1982) complementa os índices de ligações para trás e para frente na medida em que possibilita interpretar como um impacto setorial se distribui para os outros setores, no caso do índice de ligações para trás; e, quanto um dado setor é damandado pelos outros, no caso do índice de ligações para frente. A ocorrência de um baixo valor para uma determinada dispersão do índice de ligações para trás implica em dizer que o impacto de uma variação da produção no setor estimula os outros setores de maneira uniforme. Ao contrário, isto é, em se considerando um valor alto, o estímulo se concentrará em poucos setores. Para o caso de uma determinada dispersão do índice de ligação para frente, um valor alto de dispersão significa que a demanda por esse setor se concentrará em uns poucos setores, enquanto um valor baixo significa que esse setor é demandado de maneira uniforme.

As dispersões dos índices de ligações para trás e para frente são determinados, respectivamente, através das seguintes expressões: 


$$
\begin{aligned}
& V_{j}=\frac{\sqrt{\frac{\sum_{i}^{n}\left(b_{i j}-\frac{B * j}{n}\right)^{2}}{(n-1)}}}{\frac{B_{* j}}{n}} \\
& V_{i}=\frac{\sqrt{\frac{\sum_{j}^{n}\left(b_{i j}-\frac{B_{i *}}{n}\right)^{2}}{(n-1)}}}{\frac{B_{i *}}{n}}
\end{aligned}
$$

A técnica de Rasmussen e Hirschman tem sido muito utilizada para identificação de setores-chave embora receba alguns comentários críticos na literatura [McGilvray (1977) e Hewings (1982)]. Um dos problemas apontados para este indice é o de que não computam a influência dos diferentes níveis de produçăo em cada setor da economia. Fundamentado nesta crítica, Cella (1984) trabalhou numa nova metodologia de medição de índice de ligações total, através de decomposição de matrizes, e que serviu de base para o desenvolvimento de uma nova abordagem na análise de setores-chave: a noção de índice puro de ligações interindustriais (Ver Guilhoto et al., 1996).

\subsubsection{O indice puro de ligaçōes interindustriais}

Cella (1984) desenvolveu uma sistemática de cálculo de ligação interindustrial matematicamente consistente e que forneceu a base metodológica para o enfoque de Índice Puro de ligações interindustriais, o qual incorpora algumas modificações para aperfeiçoá-la (a definição original de Cella é exposto em detalhes em Guilhoto et al., 1994). 
A definição original de Cella (1984) para índices de ligações baseou-se na matriz de coeficientes diretos de Leontief $(A)$ representando as seguintes matrizes:

$$
A=\left[\begin{array}{ll}
A_{\ddot{j}} & A_{j r} \\
A_{r j} & A_{r r}
\end{array}\right]
$$

e

$$
\bar{A}=\left[\begin{array}{cc}
A_{i j} & 0 \\
0 & A_{\boldsymbol{r}}
\end{array}\right]
$$

onde $A_{j j}$ e $A_{r r}$ são matrizes de insumos diretos, do setor $j$ e do resto da economia (economia menos o setor $j$ ), respectivamente, e $A_{j r}$ e $A_{r j}$ são matrizes retangulares dos insumos diretos adquiridos pelo setor $j$ do resto da economia e os insumos diretos adquiridos pelo resto da economia do setor $j$, respectivamente. $\bar{A}$ é a matriz de coeficientes de insumos diretos usada para definir as interações apenas dentro do setor $j$ e as interações entre o resto dos setores com a exclusão do setor $j$. Teríamos, então, nesse contexto, duas economias separadas sem relações comerciais.

Conforme Sonis e Hewings (1993), a partir de (8) obtém-se:

$$
L=(I-A)^{-1}=\left[\begin{array}{ll}
\widetilde{\Delta}_{j} & \widetilde{\Delta}_{j} A_{j r} \Delta_{r} \\
\Delta_{r} A_{r j} \widetilde{\Delta}_{j} & \Delta_{r}\left(I+A_{r j} \widetilde{\Delta}_{j} A_{j r} \Delta_{r}\right)
\end{array}\right]
$$

onde:

$$
\begin{aligned}
& \widetilde{\Delta}_{j}=\left[I-A_{i j}-A_{j r} \Delta_{r} A_{r j}\right]^{-1}, \quad \mathrm{e} \\
& \Delta_{r}=\left[I-A_{r r}\right]^{-1}
\end{aligned}
$$


Seguindo a mesma sistemática, a equação (9) pode ser resolvida para a inversa de Leontief, resultando em:

$$
\bar{L}=(I-\bar{A})^{-1}=\left[\begin{array}{cc}
\Delta_{j} & 0 \\
0 & \Delta_{r}
\end{array}\right]
$$

onde:

$$
\Delta_{j}=\left(I-A_{j j}\right)^{-1}
$$

À luz da equação (8), procede-se com a seguinte decomposição:

$$
A=\left[\begin{array}{cc}
A_{j j} & A_{j r} \\
A_{r j} & A_{r r}
\end{array}\right]=\left[\begin{array}{cc}
A_{j j} & A_{j r} \\
A_{\eta j} & 0
\end{array}\right]+\left[\begin{array}{cc}
0 & 0 \\
0 & A_{r}
\end{array}\right]=A_{j}+A_{r}
$$

onde a matriz $A_{j}$ representa o setor $j$ isolado do resto da economia e a matriz $A_{r}$ representa o resto da economia.

Segundo Sonis e Hewings (1993), a partir da matriz inversa de Leontief (3), pode-se transformar a decomposição aditiva da matriz de insumos diretos (15) em decomposições multiplicativas:

$$
L=P_{2} P_{1}
$$

onde: $\quad P_{1}=\left(I-A_{r}\right)^{-1}$

$$
P_{2}=\left(I-P_{1} A_{j}\right)^{-1}
$$

A expressão (16) representa a separação da interação dentro do resto da economia $\left(P_{1}\right)$ da interação do setor $j$ com 0 resto da economia $\left(P_{2}\right)$, onde $P_{2}$ mostra os impactos diretos e indiretos que a demanda por insumos do setor $j$ terá sobre a economia $\left(P_{1} A_{j}\right)$. 
Ou:

$$
L=P_{1} P_{3}
$$

onde: $\quad P_{3}=\left(I-A_{j} P_{1}\right)^{-1}$

e se isola a interação dentro do resto da economia $\left(P_{1}\right)$ da interação do resto da economia com o setor $j\left(P_{3}\right)$. Têm-se, então, na equação (20) $P_{3}$ representando 0 nível dos impactos no setor $j$ que será produzido pelas aquisições diretas e indiretas do resto da economia $\left(A_{j} P_{1}\right)$.

A partir de (16), (17) e (18) pode-se expressar a equação (16) através de:

$$
L=\left[\begin{array}{ll}
\widetilde{\Delta}_{j} & \tilde{\Delta}_{j} A_{j r} \\
\Delta_{r} A_{r j} \widetilde{\Delta}_{j} & I+\Delta_{r} A_{r j} \tilde{\Delta}_{j} A_{j r}
\end{array}\right]\left[\begin{array}{ll}
I & 0 \\
0 & \Delta_{r}
\end{array}\right]
$$

Procedendo-se outras decomposições no primeiro termo da expressão (16) obtém-se:

$$
P_{2}=\left[\begin{array}{ll}
I & 0 \\
\Delta_{r} A_{r j} & I
\end{array}\right]\left[\begin{array}{cc}
\widetilde{\Delta}_{j} & 0 \\
0 & I
\end{array}\right]\left[\begin{array}{cc}
I & A_{j r} \\
0 & I
\end{array}\right]
$$

onde: $\quad P_{2}=\left(I-B_{j}\right)^{-1}$

e: $\quad B_{j}=P_{1} A_{j}=\left[\begin{array}{ll}A_{i j} & A_{j r} \\ \Delta_{r} A_{\eta} & 0\end{array}\right]$

A partir da expressão (24), quantifica-se 0 indice puro de ligações para trás ( $P B L$ ).

$$
P B L=\dot{i}_{r r} \Delta_{r} A_{r j} q_{i j}
$$


onde $\boldsymbol{q}_{j j}$ é o valor da produção total no setor $j, i^{\prime}{ }_{r}$ é um vetor linha unitário de dimensão apropriada e o restante das variáveis são definidas como anteriormente. A razão para se usar o valor da produção total em substituição ao valor da demanda final é o isolamento do setor $j$ do resto da economia, dado que o vetor de produção total funciona como um vetor de demanda final em termos dos impactos do setor $j$ sobre o resto da economia (Guilhoto et al., 1994).

O PBL fornece o impacto puro na economia do valor da produção total do setor $j$, expressando um impacto dissociado da demanda de insumos que o setor j realiza do próprio setor $j$, e dos retornos da economia para o setor $j$, e vice-versa.

Trabalhando com (17), (19) e (20) obtém-se:

$$
L=\left[\begin{array}{ll}
I & 0 \\
0 & \Delta_{r}
\end{array}\right]\left[\begin{array}{ll}
\widetilde{\Delta}_{j} & \widetilde{\Delta}_{j} A_{j r} \Delta_{r} \\
\Delta_{r} A_{r j} \tilde{\Delta}_{j} & I+A_{r j} \tilde{\Delta}_{j} A_{j r} \Delta_{r}
\end{array}\right]
$$

Decompondo-se o segundo termo da expressão tem-se:

$$
P_{3}=\left[\begin{array}{cc}
I & 0 \\
A_{r j} & I
\end{array}\right]\left[\begin{array}{cc}
\widetilde{\Delta}_{j} & 0 \\
0 & I
\end{array}\right]\left[\begin{array}{cc}
I & A_{j r} \Delta_{r} \\
0 & I
\end{array}\right]
$$

com: $\quad P_{3}=\left(I-F_{j}\right)^{-1}$

$\mathrm{e}: \quad F_{j}=A_{j} P_{1}=\left[\begin{array}{ll}A_{j j} & A_{j r} \Delta_{r} \\ A_{r j} & 0\end{array}\right]$

A partir da equação (29), é também possível derivar o índice puro de ligações para frente (PEL) expresso por: 


$$
P F L=A_{j r} \Delta_{r} q_{r r}
$$

onde $q_{r r}$ é um vetor coluna que representa $\bigcirc$ volume de produção total em cada setor do resto da economia. Usando o mesmo procedimento anterior, substitui-se 0 valor da demanda final pelo valor da produção total para o isolamento do setor $j$ do resto da economia. O PFL fornece o impacto puro no setor $j$ da produção total no resto da economia. ${ }^{16}$

A soma do índice puro de ligações para trás (PBL) com o indice puro de ligações para frente (PFI) resulta no indice puro do total das ligações (PTL) de cada setor na economia, uma vez que tais índices são expressos em valores correntes. Assim:

$$
P T L=P B L+P F L
$$

\subsubsection{O enfoque do campo de influência}

Os principais elos de ligação dentro da economia, isto é, os coeficientes que, se alterados, terão um maior impacto no sistema como um todo, não são retratados através dos índices de ligação mencionados. O conceito de campo de influência [Sonis e Hewings (1989) e (1994)], complementarmente aos indices de ligações, permite determinar quais as relações entre os setores mais importantes dentro do processo produtivo em estudo.

- procedimento para o cálculo do campo de influência requer a matriz de coeficientes diretos $A=\left|a_{i j}\right|$ e

\footnotetext{
16 As derivações aqui expostas foram extraidas integralmente de Guilhoto et al. (1994).
} 
é preciso definir a matriz de variações incrementais nos coeficientes diretos de insumo $E=\left|\varepsilon_{i j}\right|$. As correspondentes matrizes inversas de Leontief são dadas por $B=[I-A]^{-1}=\left|b_{i}\right|$ e por $B(\varepsilon)=[I-A-\varepsilon]^{-1}=\left|b_{i j}(\varepsilon)\right|$. Segundo Sonis e Hewings 11989 e 1994), caso a variação seja pequena e só ocorra num coeficiente direto, isto é:

$$
\varepsilon_{i j}=\left\{\begin{array}{lll}
\varepsilon & i=i_{1} & , j=j_{1} \\
0 & i \neq i_{1} & \text { ou } j \neq j_{1}
\end{array}\right.
$$

tem-se que o campo de influência desta variação pode ser aproximado pela expressão:

$$
F\left(\varepsilon_{i j}\right)=\frac{\left[B\left(\varepsilon_{i j}\right)-B\right]}{\varepsilon_{i j}}
$$

onde $F\left(\varepsilon_{i j}\right)$ é uma matriz ( $n \times \mathrm{x} n$ ) do campo de influência do coeficiente $a_{i j}$.

Para se determinar quais serão os coeficientes que possuirão o maior campo de influência torna-se necessário associar a cada matriz $F\left(\varepsilon_{i j}\right)$ um valor. Assim sendo, tem-se que este valor será dado por:

$$
S_{i j}=\sum_{k=1}^{n} \sum_{l=1}^{n}\left[f_{k l}\left(\varepsilon_{i j}\right)\right]^{2}
$$

onde $S_{i j}$ é o valor associado à matriz $F\left(\varepsilon_{i j}\right)$; logo, os coeficientes diretos que possuírem os maiores valores de $S_{i j}$ serão aqueles com $\circ$ maior campo de influência dentro da economia como um todo. ${ }^{17}$

\footnotetext{
17 Ver Sonis e Hewings (1989, 1994) para maior detalhamento da metodologia exposta.
} 


\subsection{Os setores industriais ligados à agricultura}

A composição do CAI, formado pelos seus principais ramos a montante e a jusante da agricultura, pode ser vista como um indicador síntese da ordem de magnitude desse complexo industrial, e a partir dessa composição obter inferências das relações interindustriais do tipo insumoproduto. Isto é o que se pretende fazer através da análise da composição e evolução do PIB do Complexo Agroindustrial Brasileiro.

Para tal, necessário se faz definir os critérios que vão permear a escolha dos setores compreendidos no grupo de industrias abastecedoras de insumos e bens de capital para a agricultura (indústria para a agricultura) e no grupo de indústrias processadoras de alimentos e matérias-primas da agricultura /indústria de base agrícola).

Como já abordado no capítulo 2 , referente a revisão bibliográfica, a expressão agroindústria tem sido utilizada com diferentes objetivos, ou seja, com diferentes dimensões. Percebe-se nitidamente que há divergências sobre a questão conceitual de CAI e agroindústria ainda não havendo um consenso, o que provoca dificuldades metodológicas em estabelecer $\circ$ que realmente deve ser englobado nestes conceitos. Na verdade, a conceituação a ser utilizada fica a critério do analista, dependendo do que se quer enfatizar, do nível de análise e da disponibilidade de informações.

Neste trabalho, um novo procedimento é apresentado visando a delimitação dos componentes do Complexo Agroindustrial. 
Numa outra perspectiva, pode-se derivar da equação (24) uma matriz retangular que mostra, respectivamente, os insumos diretos e indiretos adquiridos pelo setor $j$ do resto da economia (economia menos o setor $j$ ) e os insumos diretos e indiretos adquiridos pelo resto da economia do setor $j$. Em essência, pode-se imaginar que estas divisões representam duas economias separadas sem relações comerciais. Assim, tem-se:

$$
G U_{j}=\Delta_{r} A_{r j} q_{j j}
$$

onde as variáveis são definidas como anteriormente. Novamente, a razão para se usar o valor da produção total no lugar do valor da demanda final é o isolamento do setor $j$ do resto da economia, como já explicado.

- GU nos dá, em cada coluna, o impacto direto e indireto na economia do valor da produção total do setor $j$. Este impacto é dissociado da demanda de insumos que o setor $j$ realiza do próprio setor $j$. Por outro lado, nas linhas, tem-se o impacto direto e indireto no setor $j$ da produção total do resto da economia.

A derivação obtida fornece um procedimento analítico que permite quantificar a influência de um setor específico sobre o resto da economia. Esta metodologia pode ser usada para auxiliar na análise da importância dos diferentes setores que compõem a economia em termos dos impactos globais. O principal problema dos métodos estudados é que, apesar de analisarem a importância dos setores em termos dos impactos globais não permitem mensurá-los. 
A partir desse modelo (GU) gera-se uma matriz $A G R$ (41 x 42), apresentada no Apêndice 2, que permite identificar as inter-relações entre as atividades agropecuárias e os demais setores da economia. Na coluna da matriz $A G R$, referente ao setor agropecuário (primeira coluna) têm-se a estrutura de consumo (direto e indireto) da respectiva atividade, como demandante de insumos do resto da economia, em valores correntes. Excetuando 0 primeiro elemento, ao longo da primeira linha dessa matriz lê-se 0 destino da produção agropecuária em valores correntes, como insumos dos diferentes setores (impacto direto e indireto).

Note que em cada coluna da Matriz AGR, exclue-se 0 elemento do setor a ele correspondente.

Dessa forma, os valores da primeira coluna, quando ordenados em ordem decrescente, mostram a importância dos diferentes setores da economia como ofertantes de insumos para o setor agrícola. Os valores da primeira linha, quando ordenados da mesma forma, revelam os principais setores demandantes de produtos agrícolas.

\subsection{Produto Interno Bruto}

Os agregados macroeconômicos são medidas-síntese do resultado da atividade do conjunto da economia, propiciando comparações tanto espaciais como temporais. Existem os agregados que representam diretamente as operações do sistema, como por exemplo, a produção de bens e serviços, o consumo final e os agregados que apresentam saldos contábeis, incluindo o produto interno bruto (PIB), a renda 
nacional bruta disponível e a poupança nacional bruta, entre outros (FIBGE, 1989).

O cálculo dos agregados pode ser obtido na forma bruta ou líquida, conforme incluam ou não o consumo de capital fixo (depreciação). As dificuldades envolvidas nas estimativas dos valores líquidos fazem com que as instituições responsáveis por esses cálculos, tanto nacional como internacionalmente, apresentem usualmente os agregados em termos brutos.

O cálculo do produto nacional pode ser efetuado a preços de mercado ou a custo dos fatores de produção. O produto pode ser medido pela soma dos valores adicionados nos diversos estágios de produção ou pelo somatório dos bens finais, ambos avaliados a preços de mercado. A diferença entre a medida a preços de mercado e a custos de fatores é dada pelo montante de impostos indiretos (Pinho, 1988 ).

Segundo Pinho (1988), na aferição do desempenho de uma economia em termos de renda e produto, 0 que se pretende avaliar é o bem-estar obtido pelos indivíduos por meio da atividade econômica. Por essa razão, é comum associar as taxas de crescimento do PIB, por exemplo, a crescimento de bem-estar. No entanto, deve-se ressaltar que essa vinculação entre produto e bem-estar só pode ser realizada em condições muito restritas. Para maior detalhamento sobre as dificuldades na utilização do PIB como referencial de crescimento de bem-estar consultar Pinho (1988). 


\title{
3.4.1 O conceito de produto interno bruto (PIB)
}

\begin{abstract}
- Produto Interno ${ }^{18}$ Bruto (PIB) constitui-se no principal agregado das Contas Nacionais, sendo um indicador que procura expressar o crescimento de uma economia abarcando todos os seus ramos, ou seja, a produção de todos os serviços e mercadorias finais dentro das fronteiras do país, num determinado ano (EIBGE, 1989).
\end{abstract}

Por ser um indicador relevante, a taxa de crescimento do PIB anual dos vários setores da atividade econômica é um número sempre esperado com expectativa por permitir avaliações econômicas do período, sendo indiscutível sua importância, tanto que atualmente as instituições pertinentes, nacionais e internacionais, estão se dedicando a elaborar cálculos trimestrais do PIB.

Existem três procedimentos através dos quais podem ser obtidos índices de produto Interno Bruto. ${ }^{19}$

No primeiro caso o PIB inclui o consumo final, a formação bruta de capital fixo, a variação de estoque, exportações subtraindo as importações. Vale dizer, considera-se o valor dos bens e serviços resultantes de produção de unidades residentes que são disponíveis para uso final. Tem-se, então:

$$
\text { PIB = demanda final - importação }
$$

\footnotetext{
18 A diferença entre produto interno e produto nacional corresponde a renda liquida enviada para pagamento de fatores de propriedade de nåo residentes, ou seja, PNB + Renda Liquida enviada ao exterior = PIB.

19 IBGE. Novo Sistema de Contas Nacionais: Metodologia e resultados provisórios ano-base 1980, vol. 1, nㅇ 10, dezembro/1988.
} 
No segundo caso, define-se o PIB como sendo igual à produção das unidades institucionais residentes diminuida do consumo intermediário, ou seja, o valor adicionado. Neste enfoque, deve-se levar em conta as normas utilizadas para contabilização da produção. No caso do IBGE a produção é valorada excluindo os impostos e subsidios sobre produtos. Desta forma, há necessidade de acrescentar ao valor adicionado setorial o montante de impostos menos subsídios sobre produtos.

$$
\begin{aligned}
\mathrm{PIB}= & \text { valor adicionado por setor + impostos sobre } \\
& \text { produtos - subsídios sobre produtos. }
\end{aligned}
$$

No terceiro caso, $O$ PIB pode ser estimado pelo seguinte enfoque:

$$
\begin{aligned}
\text { PIB }= & \text { remuneração dos assalariados }+ \text { impostos } \\
& \text { líquidos sobre atividade }+ \text { excedente } \\
& \text { operacional bruto }+ \text { impostos líquidos sobre } \\
& \text { produtos (impostos - subsidios). }
\end{aligned}
$$

A escolha da maneira de calcular o PIB, tanto a preços correntes quanto a preços constantes, envolve tanto considerações técnicas quanto de ordem operacionais (disponibilidade de informações, qualidade).

o procedimento adotado pelo Departamento de Contas Nacionais (DECNA/IBGE) para a estimativa do PIB, principalmente para os anos censitários, se dá pelo enfoque do Produto, ou seja, do cálculo do Valor Adicionado. A definição conceitual dos agregados macroeconômicos envolvidos nessa operação, adotada por essa Instituição, 
seguindo as recomendações internacionais, está descrita a seguir. 20

\section{PRODUÇÃO}

A produção é a atividade econômica socialmente organizada que consiste em criar bens e serviços, quer sejam para serem oferecidos no mercado ou não. Compreende assim a produção de bens e serviços dos produtores mercantis, bem como os Serviços das Administrações Públicas, os Serviços das Instituiçőes Privadas Sem Fins Lucrativos que prestam às familias, e os serviços Domésticos Remunerados. São classificadas como mercantis as atividades que se financiam através da produção de bens e serviços a serem comercializados ou suscetíveis de serem comercializados, a um preço com o qual se pretende normalmente cobrir ao menos os custos de produção.

\section{CONSUMO INTEERMEDIÁRIO}

O consumo Intermediário representa o valor dos bens e dos serviços consumidos no processo de produção. Não inclui os bens de capital e os serviços ligados à transferência ou instalação de ativos fixos.

Da mesma forma que o Valor da Produção, o valor do Consumo Intermediário está relacionado às atividades mercantis ou não-mercantis.

\footnotetext{
20 As conceituações foram extraidas integralmente do texto sistema de Contas Nacionais Consolidadas - Brasil. IBGE, Série Relatórios Metodológicos, vol. 8, 1990.
} 


\title{
VALOR ADICIONADO
}

\begin{abstract}
Valor Adicionado é o saldo entre o Valor da Produção e o Consumo Intermediário. Conceitualmente, corresponde ao Valor Adicionado pelos fatores de produção durante o processo produtivo, em cada atividade econômica.
\end{abstract}

\section{IMPOSTOS OU TRIBUTOS INDIRETOS}

Os Impostos Indiretos ou impostos ligados à produção e à importação são pagamentos obrigatórios exigidos pelo Estado às unidades produtoras e incidem sobre a produção, a venda, a importação e a exportação de bens e serviços ou a utilização de fatores de produção. Estes impostos são devidos independentemente dos resultados contábeis das unidades de produção, isto é, da realização e montante de lucro operacional. Constituem recursos das Administrações públicas, sendo registrados no momento em que são efetivamente pagos. Esses impostos se subdividem em impostos sobre produto e impostos ligados à produção (atividades). Os impostos sobre produto, além do imposto sobre importação, incluem impostos sobre o Valor Adicionado e impostos diretamente incidentes sobre produtos de origem nacional. Os impostos indiretos ligados à atividade são os incidentes sobre a folha de salários, licenças, alvarás e outros, não relacionados ao volume ou valor da produção.

\section{SUBSÍDIOS}

Os Subsidios são definidos como transferências correntes das Administrações Públicas para as unidades de produção mercantis com o objetivo de reduzir o preço de 
mercado dos produtos ou permitir uma rentabilidade suficiente à atividade. Podem ser subdivididos em subsídios aos produtos e à atividade produtiva. Os subsídios aos produtos são aqueles que mantêm uma proporção com o valor ou a quantidade dos bens e serviços comercializados no mercado interno ou exportados. Como subsídios à atividade produtiva são agrupados aqueles que visam compensar os custos de operação de forma a garantir o nível de rentabilidade da unidade produtiva ou apenas zerar seu déficit operacional.

\subsubsection{Metodologia e fómula de cálculo}

A subtração do Consumo Intermediário do valor da Produção resulta no Valor Adicionado a preços correntes que pode ser obtido a custo de fatores e a preços básicos.

Teoricamente os níveis de valoração são definidos como:

Preço Aproximadamente Básico: é o Preço de Produtor menos os Impostos Indiretos sobre Produtos.

Preço de consumidor: é o preço total pago pelo consumidor na aquisição de um produto como consumo Intermediário ou Demanda Einal. Este preço inclui as Margens de Distribuição, o Imposto sobre Valor Adicionado (IVA) não dedutível, e os Impostos Indiretos sobre Produtos e Atividades.

Preço a Custo de Fator Aproximado: é o preço aproximadamente básico menos os impostos indiretos sobre atividades. 
Assim, tem-se que o Valor Adicionado a preços básicos ${ }^{21}$ é obtido pela diferença entre o Valor da produção a preços aproximadamente básicos e o consumo Intermediário a preços de consumidor, resultando na seguinte expressão:

Valor Adicionado $_{p b}=$ Valor da Produçãopab - Consumo Intermediáriopi

ou alternativamente

Valor Adicionadopb $=$ Remuneração dos Assalariados + Impostos sobre a Atividade - Subsídios à Atividade + Excedente Operacional Bruto;

Para obter o Valor Adicionado a custo de fatores deduz-se os Impostos liquidos de subsidios sobre a atividade, ou seja:

Valor Adicionado Af $=$ Valor Adicionadopb - Impostos sobre a Atividade + Subsídios à Atividade;

ou

Valor Adicionado Af $=$ Remuneração dos Assalariados + Excedente Bruto

Para se chegar ao PIB a preços de mercado é necessário adicionar os impostos líquidos de subsídios sobre produtos ao Valor Adicionado a preços básicos.

Os cálculos efetuados para os anos intercensitários são realizados através de uma combinação de índices de

21 Para uma discussão mais detalhada sobre os niveis de valoração adotados pelo DECNA ver Fundação IBGE: Sistema de Contas Nacionais Consolidadas, Brasil, op. cit, p. 15-16. 
produto real e índices de preços, gerando o índice de valor.

A fórmula do índice de crescimento real ou índice de quantum - de cada atividade econômica e para o total do PIB - adotada pelo FIBGE é a de Laspeyres, definida analiticamente por:

$$
L_{o, t}=\frac{\sum_{i=1}^{n} P_{i o} Q_{i t}}{\sum_{i=1}^{n} P_{i o} Q_{i o}}
$$

- numerador da expressão representa $O$ Valor da Produção no período $t$ e 0 denominador $\circ$ Valor da Produção no período $O$, ambos valorados aos preços do período 0 (preços constantes no ano-base), onde:

$$
\begin{aligned}
& P_{i \circ} \text { é o preço do produto } i \text { no período } 0 ; \\
& Q_{i \circ} \text { é a quantidade do produto } i \text { no período } 0 ; \\
& Q_{i t} \text { é a quantidade do produto } i \text { no período t; } \\
& i=1, \ldots, n \text { são os produtos } \\
& 0 \text { é o período-base; e } \\
& t \text { é o período de referência do índice. }
\end{aligned}
$$

Esta fórmula utiliza a estrutura do valor Adicionado dos anos-base como ponderação. ${ }^{22}$

o indice de quantidade proposto por Laspeyres, na sua formulação original, considera os preços da época básica como fatores de ponderação. Enquanto no índice de preço a diferença da importância gasta se deve à variação

\footnotetext{
22 Produto Interno Bruto - Brasil. Rio de Janeiro: IBGE, Diretoria de Pesquisas. Série Relatórios Metodológicos, n요 9, 1990.
} 
nos preços, no de quantidade ela se deve à variação nas quantidades adquiridas, uma vez que os preços permanecem constantes (Toledo \& Ovalle, 1983).

\subsubsection{Cálculo do Produto Interno Bruto do Complexo Agroindustrial Brasileiro}

Para a análise do complexo agroindustrial brasileiro, como já mencionado, utiliza-se a matriz insumoproduto que fornece um número elevado de setores que caracterizam o complexo agroindustrial brasileiro.

A técnica de insumo-produto foi desenvolvida visando a análise das relações entre os setores produtivos e de consumo de uma economia nacional, permitindo uma análise "sistêmica" e "integrada" de todo fluxo do produto.

Os pressupostos implícitos no uso da matriz insumoproduto săo:

a) os coeficientes técnicos de insumo-produto são fixos, o que significa supor funções de produção lineares;

b) ignoram-se mudanças nos preços relativos;

c) supõe-se que as mudanças tecnológicas são lentas;

d) todos os bens e serviços incluidos na matriz apresentam uma oferta infinitamente elástica, ou seja, toda a demanda adicional será coberta expandindo-se a produção aos custos representados na matriz.

Adota-se para a estimativa do Complexo Agroindustrial Brasileiro a metodologia descrita a seguir. ${ }^{23}$

Para o cálculo do PIB do Agregado I (Indústria para a agricultura) são utilizadas as informações disponíveis 23 Ver seção 4.2 para detalhamento sobre a composição do Complexo
Agroindustrial Brasileiro. 
nas tabelas de insumo-produto referentes ao valor total dos insumos adquiridos pelo Agregado II (Agropecuária). Esta sistemática foi utilizada por não se dispor de estatisticas que permitam identificar a parcela do valor adicionado das indústrias ofertantes de insumos absorvida pelo setor rural. Por isso, o PIB do Agregado I é estimado indiretamente a partir da composição do consumo intermediário da agropecuária. A hipótese implícita no uso de indicadores de consumo intermediário da agricultura para cálculo do valor agregado das atividades a montante do CAI é de que os setores industriais fornecedores de insumos e bens de capital para o setor rural apresentam um consumo de produtos agricolas praticamente nulo, demandando basicamente bens intermediários de seus próprios setores. As Tabelas 5, 6 e 7 mostram, para os periodos em análise, os percentuais de insumos agricolas adquiridos pelos setores industriais (menos os setores agroindustriais) e os coeficientes técnicos dos insumos nacionais nos respectivos processos produtivos. Os dados comprovam a hipótese de que a agropecuária tem uma menor participação no processo produtivo das industrias em geral. A grande maioria dos 29 setores analisados - cerca de 90\% - utiliza uma quantidade insignificante de insumos agrícolas com coeficientes inferiores a $1 \%$. Os setores restantes apresentam coeficientes que variam entre 1 e $3 \%$

Araújo et al. (1990) também adotam a estrutura de gastos do setor agropecuário como proxy do valor da prodụção do setor de insumos e bens de produção para a agricultura. 


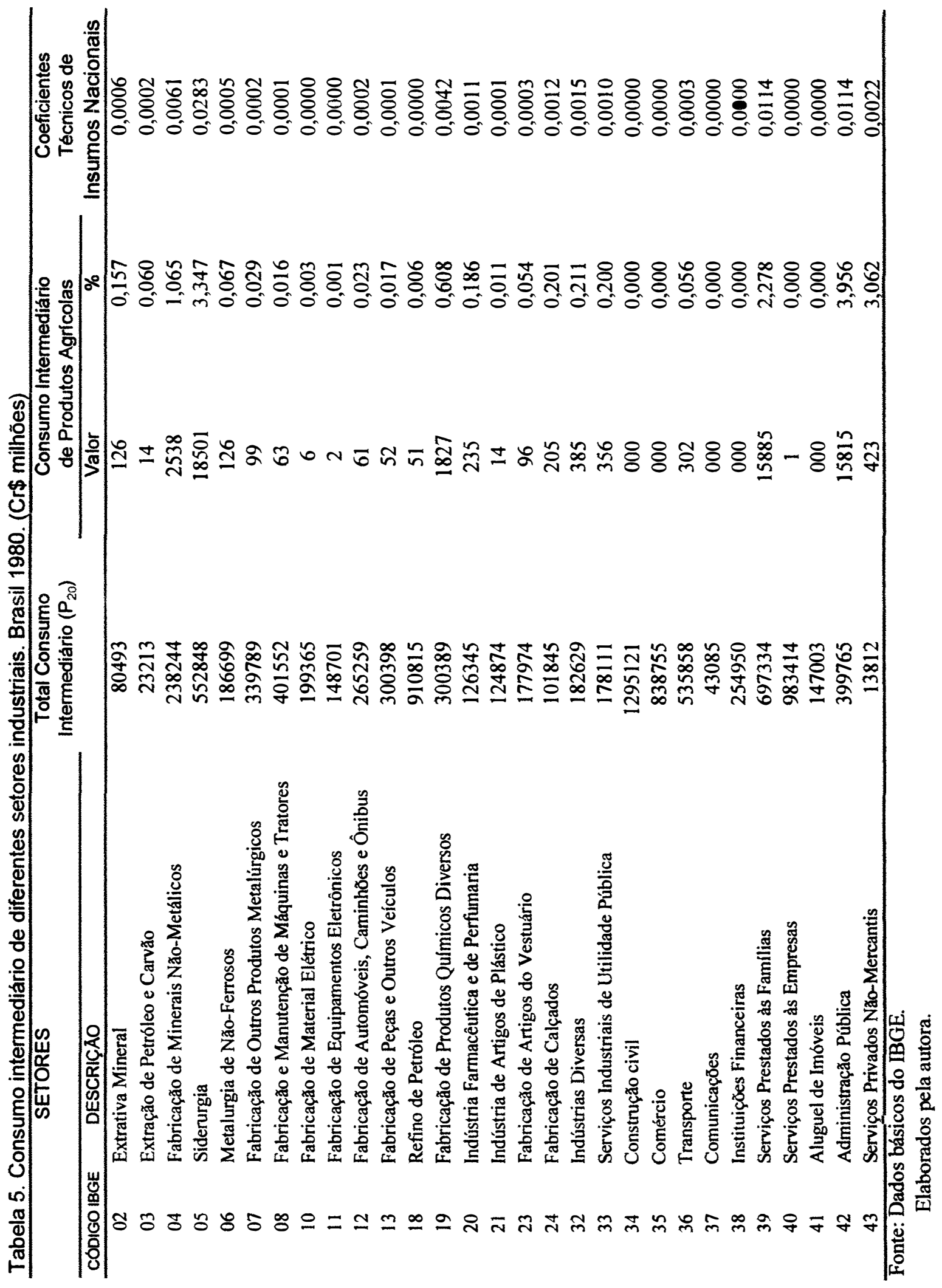




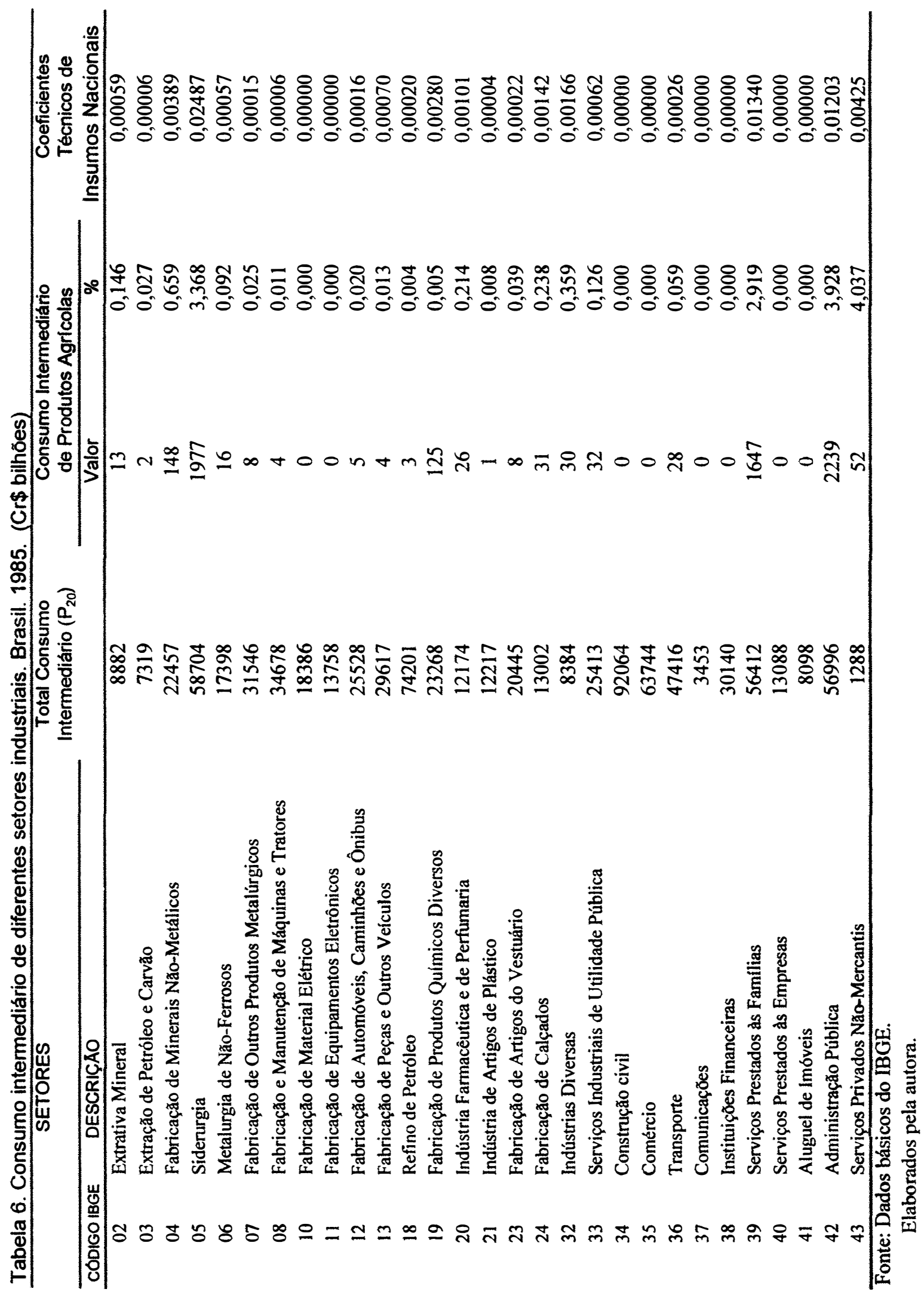




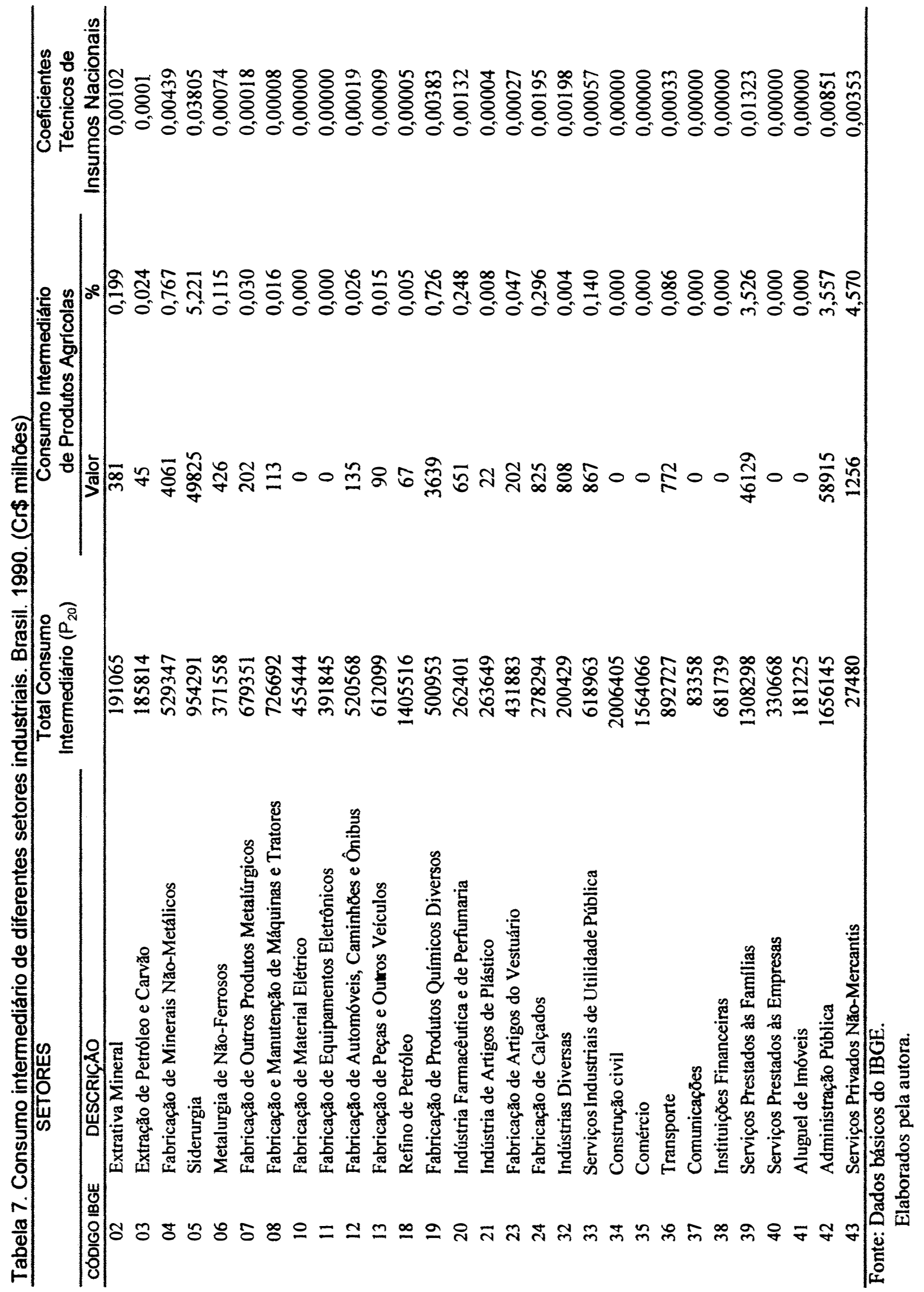


Para O Agregado I I (Agropecuária) considera-se no cálculo o valor adicionado pelo setor agropecuário e extrativo-vegetal.

No caso do Agregado III (Indústria de base agrícola) adota-se apenas o valor adicionado pelo setor agroindustrial, entre os setores produtivos.

O ramo Indústria de base agrícola (agroindústrias) ficou constituído pelas seguintes atividades:

Versão $1: 17$ - Fabricação de elementos químicos: 25 Indústria do café; 26 - Beneficiamento de produtos vegetais; 27 - Abate de animais; 28 Indústria de laticínios; 29 - Fabricação de açúcar; 30 -Eabricação de óleos vegetais. Versão 2 : incluem todas as atividades referentes a Versão 1 mais os setores 14 - Madeira e Mobiliário e 31 Eabricação de outros produtos alimentares.

Versão 3 : incluem todas as atividades da versão 2 mais 0 setor 22 - Indústria Textil.

Desta forma, os Agregados II e III expressam a renda ou valor adicionado por esses segmentos. Saliente-se que os dados das matrizes de insumo-produto referentes aos anos 80/85/90 mostram que, em média, do total da produção agropecuária e extrativa-vegetal destinada à utilização intermediária $21,8 \%$ são absorvidos pelo setor rural, 71,8\% são vendidos à agroindústria (versão 3) e somente 6,4\% são destinados aos setores restantes. 
No caso do Agregado IV, referente à Distribuição Final, considera-se para fins de cálculo o valor agregado dos setores relativos ao "Transporte", "Comércio" e segmentos de "Serviços". Do valor total obtido destina-se ao Complexo Agroindustrial apenas a parcela que corresponde à participação dos produtos agropecuários extrativovegetais e produtos agroindustriais na demanda final de produtos. Desta forma, em média, destina-se ao CAI de $14,03 \%$ (versão 1 ) a $18,85 \%$ (versão 3) do valor da distribuição final atribuível à demanda final global da economia.

A sistemática adotada no cálculo do valor da distribuição final do complexo agroindustrial pode ser representada por:

a) $D F G P-I I L-P I_{m p}=D F G P_{r} I_{n}$

Para obter a demanda final apenas da produção interna exclui-se da mesma os produtos importados e impostos indiretos líquidos.

b) $V A T_{r}+I I L_{a t / r}+V A C_{m}+I I L_{a t / c m}+V A S_{r}+I I L_{a t / s r}=T D_{r}$

c) $D F P R+D F P A_{\text {groin }}=D F G P R A_{\text {groin }}$

d) $\% D F G P R A_{\text {groin }}=\frac{D F G P R A_{\text {groin }}}{D F G P_{r} I_{n}} \times 100$

e) $V A D_{r} R A_{\text {groin }}=\% D F G P R A_{\text {groin }}\left(T D_{r}\right)$

onde:

$D F G P=$ demanda final global de produtos

IIL = impostos indiretos líquidos sobre produtos

$P I_{m p} \quad=$ produtos importados 
$D F G P_{r} I_{n}=$ demanda final global da produção interna

$V A T_{r}=$ valor adicionado pelo setor transporte

$I I L_{a t / r}=$ impostos indiretos líquidos da atividade transporte

$V A C_{m} \quad=$ valor adicionado pelo setor comércio

$I I L_{a t c m}=$ impostos indiretos líquidos da atividade comércio

$V A S_{r} \quad=$ valor adicionado pelo setor serviços

$I I L_{a t}$ sr $=$ impostos indiretos líquidos da atividade serviços

TD $\quad=$ total da distribuição ou margem de comercialização

DFPR = demanda final de produtos agropecuários e extrativo-vegetais

$D F P A_{\text {groin }}=$ demanda final de produtos agroindustriais

$D F G P R A_{\text {grom }}=$ demanda final global de produtos rurais e agroindustriais

$V A D_{r} R A_{\text {groin }}=$ valor adicionado pelor setor de distribuição final relativos ao setor rural e agroindustrial

Lauschner (1993) também adota esse procedimento indireto para o cálculo da contribuição do setor de distribuição no "agribusiness".

Por sua vez, Araújo et al. (1990) também fazem a imputação das despesas de distribuição dos produtos produzidos pelo CAI de forma indireta adotando a premissa de que, "para colocar os produtos físicos da economia à disposição dos consumidores, o setor de serviços agregou uma média de $38 \%$ em valor sobre o resultado da totalização do PIB agrícola e do industrial. Assim, ao valor da 
produção do segmento agroindustrial adicionou-se $38 \%$ para se chegar à renda que os consumidores finais empregaram para aquisição das mercadorias do CAI".

A Tabela 8 apresenta 0 resumo das contas do complexo agroindustrial brasileiro no presente estudo.

Tabela 8. Resumo das contas do complexo agroindustrial brasileiro:

\section{I - INDÚSTRIA PARA A AGRICULTTURA}

1 Minerais

2 Metalurgia

3 Mecânica

4 Elétrica

5 Química

6 Farmácia

7 Sacaria e embalagens

8 Agroindústrias

9 Rações Industriais

10 Outros Produtos Industriais

11 Energia Elétrica

12 Construção Civil

13 Comércio

14 Transporte

15 Serviços

\section{II - PRODUÇÃO RURAI}

Valor adicionado do setor agropecuário e extrativo-vegetal, mais impostos indiretos liquidos.

III - INDÚSTRIA DE BASE AGRÍCOIA

Valor adicionado do setor agroindustrial, mais impostos indiretos Iíquidos.

IV - DISTRIBUIÇÃO FINAL

Valor adicionado dos setores transporte, comércio e serviços, mais impostos indiretos líquidos relativos aos produtos agropecuária, extrativovegetais e agroindustriais. 
Deve-se ressaltar que devido a forma de cálculo adotada para o agregado III (Indústria de base agrícola) teremos três versões também para o Complexo Agroindustrial Brasileiro.

\subsubsection{Estimativa do Produto Interno Bruto a Preços Constantes}

Como já delineado, a estimativa do Valor Adicionado a preços correntes é obtida com base em informações sobre a produção e o consumo intermediário dos principais produtos da atividade, utilizando-se a hipótese que a relação entre - Valor Adicionado e o Valor da Produção é constante (VA/VP constante), no ano-base. ${ }^{24}$

A estimativa a preços constantes é de suma relevância, principalmente em períodos em que o ritmo da inflação se acentua, o que introduz graves distorções nos indicadores a preços correntes. A metodologia pertinente mostra vários procedimentos para o cálculo do valor Adicionado a preços constantes.

Segundo O IBGE (1988), são freqüentes estimativas de flutuações do produto real através das respectivas quantidades físicas produzidas, sendo possível em setores cujo produto tem uma equivalência física, como é o caso da indústria e agricultura.

Adota-se com relativa freqüência, também, o Valor da Produção deflacionado como "proxy" do produto real. Neste procedimento supõe-se uma relação constante entre o Consumo Intermediário e o valor da Produção a preços

\footnotetext{
24 As matrizes 90/95 trabalham com a estrutura básica de 85, isto é, os valores do ano-base de 1985 (preço médio do Censo/85).
} 
constantes. É importante salientar a necessidade de deflatores adequados que correspondam as alterações de preços dos bens analisados.

No caso de atividades econômicas que não dispõem de uma contrapartida física de produtos, como é o caso do setor de serviços, a alternativa recomendada é a adoção de indicadores indiretos em substituição aos indicadores de "quantum" (Valente et al., 1988).

A escolha entre a utilização dos indicadores de "quantum" e dos índices de preços para obtenção dos dados a preços constantes passa, na prática, por questões mais operacionais, como, por exemplo, a disponibilidade das informações e sua qualidade, do que por questões teóricas.

As estimativas do Produto Interno Bruto, a preços de mercado em termos constantes, cuja responsabilidade fica a cargo do IBGE através do seu Departamento de Contas Nacionais - DECNA —, são obtidas através da utilização dos índices anuais, globais, de produto real ao valor a preços correntes, no ano-base. Estes índices são o produto da agregação dos índices de produto real estimados para as diferentes atividades que compõem a economia.

O objetivo, tanto no método que utiliza-se o índice de "quantum" (extrapolação) como no índice de preço (deflação), para o cálculo do valor Adicionado a preços constantes é o de eliminar os efeitos da variação de preços na comparação dos agregados econômicos.

Para as estimativas do Valor Adicionado a preços constantes na série de 1980 a 1994, utiliza-se o processo de deflacionamento, seguindo as recomendações interna- 
cionais para o tratamento de matrizes. ${ }^{25}$ Como índices de preços adota-se as séries publicadas pela Eundação Getúlio Vargas trabalhando com indices especificos por produto. Basicamente, adota-se o indice de preços recebidos pelos agricultores para os produtos da agropecuária e o índice de preços por atacado (IPA) para os produtos industriais, selecionando o índice do gênero mais próximo ou O IPA médio anual. Para as atividades ligadas ao segmento serviços optou-se pelo índice geral de preços (IGP - Conceito Disponibilidade Interna), por não se dispor de informações específicas para esse ramo de atividade. ${ }^{26}$

Para uma discussão sobre o procedimento de deflacionamento em matrizes Insumo-Produto ver Milier \& Blair (1985).

26 A relação desses indices encontra-se no Apêndice 3. 


\section{ANÁLISE DOS RESULTADOS}

\subsection{Estrutura produtiva e setores-chave}

\subsubsection{Estrutura produtiva da economia brasileira}

As Tabelas 9 a 12 e as Figuras 2 a 13 apresentam um panorama da economia brasileira em 1980, 1985 e 1990 no intuito de entender melhor os processos de ajuste estrutural visando novos caminhos de desenvolvimento.

A análise comparativa da estrutura da produção da economia brasileira, apresentada na Tabela 9 e Figuras 2 a 4, mostra que embora a estrutura industrial tenha permanecido mais ou menos constante no período 1980-90, algumas tendências podem ser registradas. A agroindústria reduziu a sua participação na produção passando de $12,53 \%$ em 1980 para 9,92\% em 1990 (agroindústria - versão 3: setores 14 - Madeira e Mobiliário, 17 - Fabricação de Elementos Químicos, 22 - Indústria Têxtil, 25 - Indústria do Café, 26 - Beneficiamento de Produtos Vegetais, 27 Abate de Animais, 28 - Indústria de Laticínios, 29 Fabricação de Açúcar, 30 - Fabricação de Óleos Vegetais, 31 - Fabricação de Outros Produtos Alimentares). A participação do setor agrícola também diminuiu e os principais setores que compõem a Indústria para Agricultura (setores 18 - Refino do Petróleo, 19 - Fabricação de Produtos Químicos Diversos, 


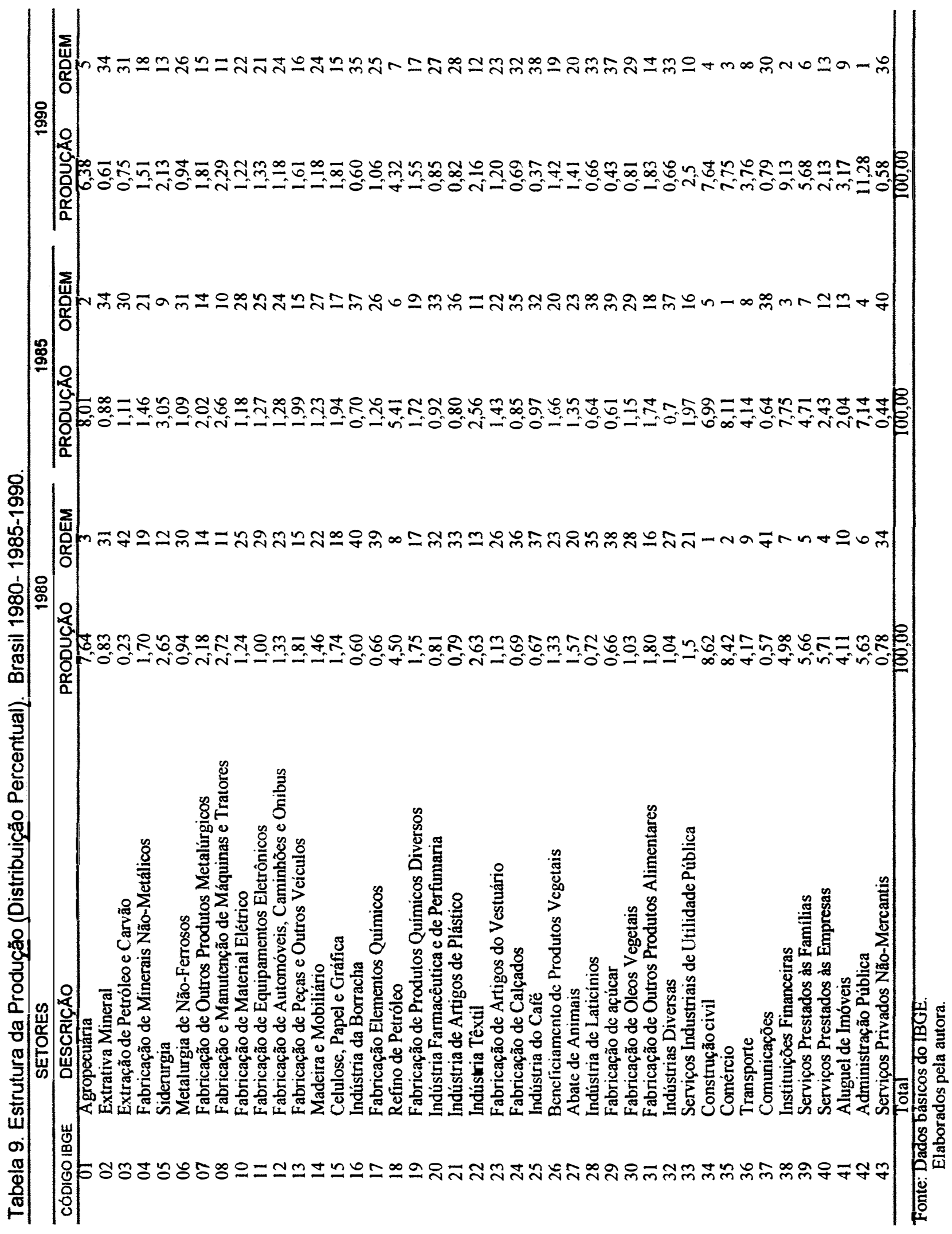




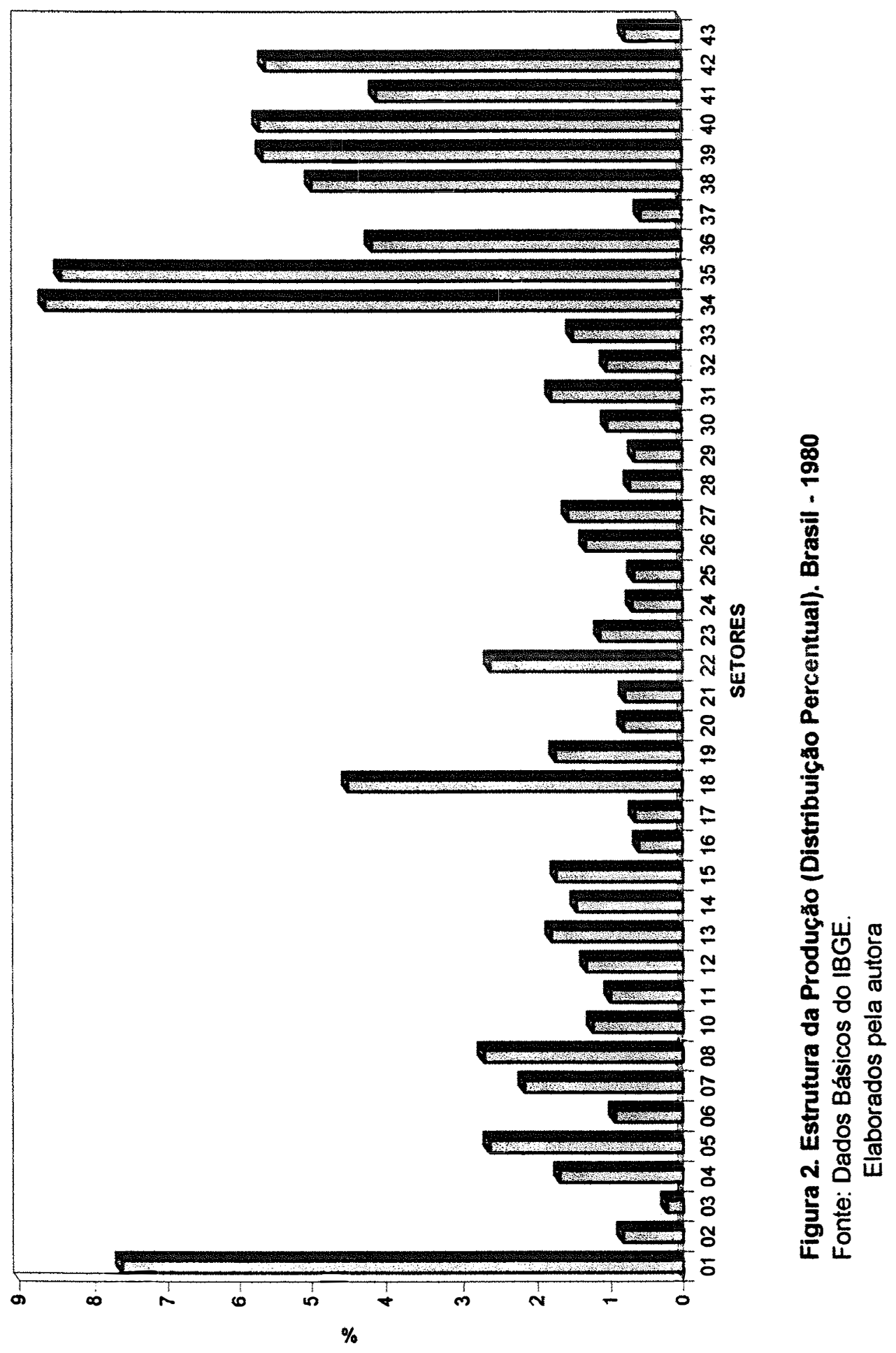




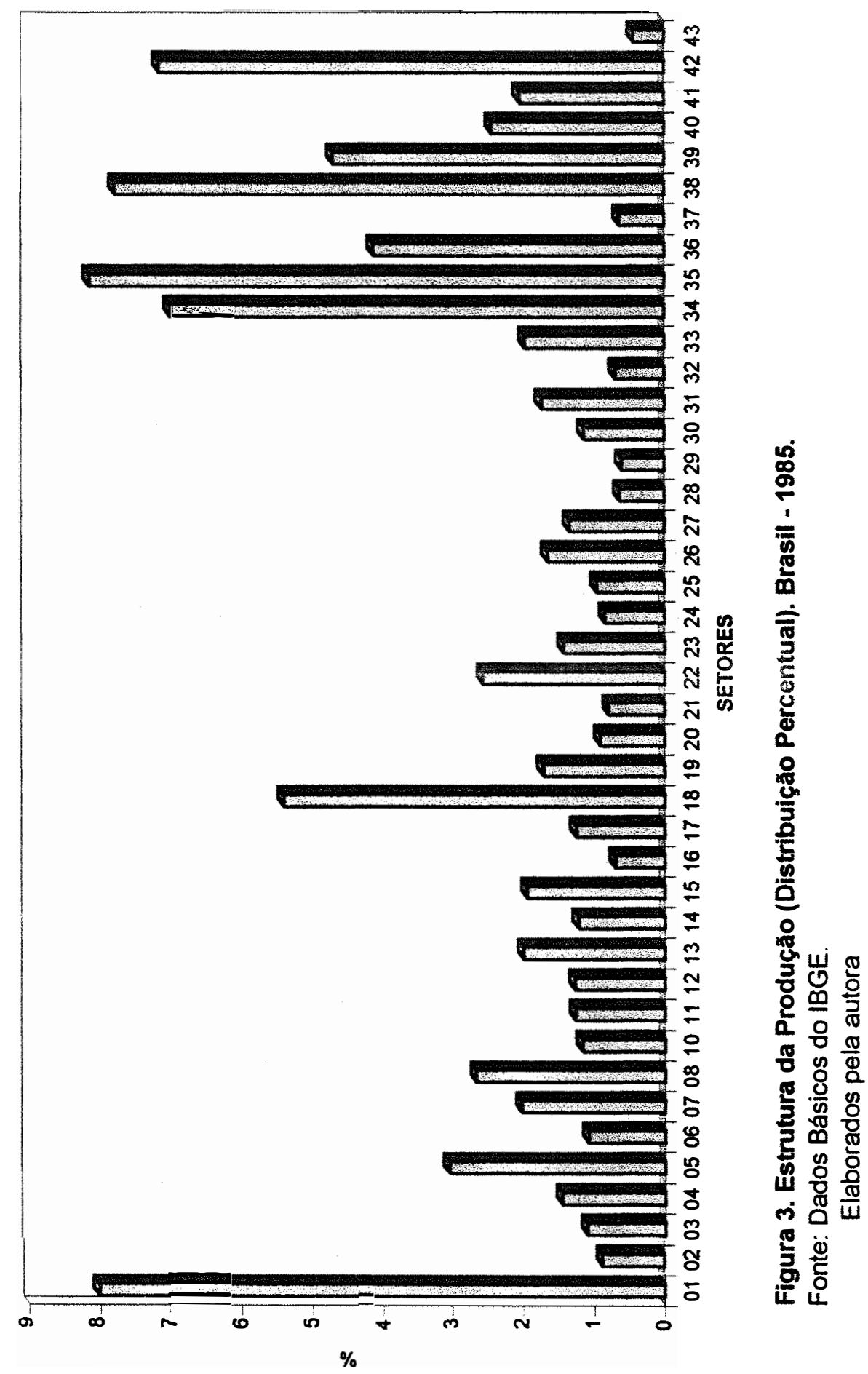




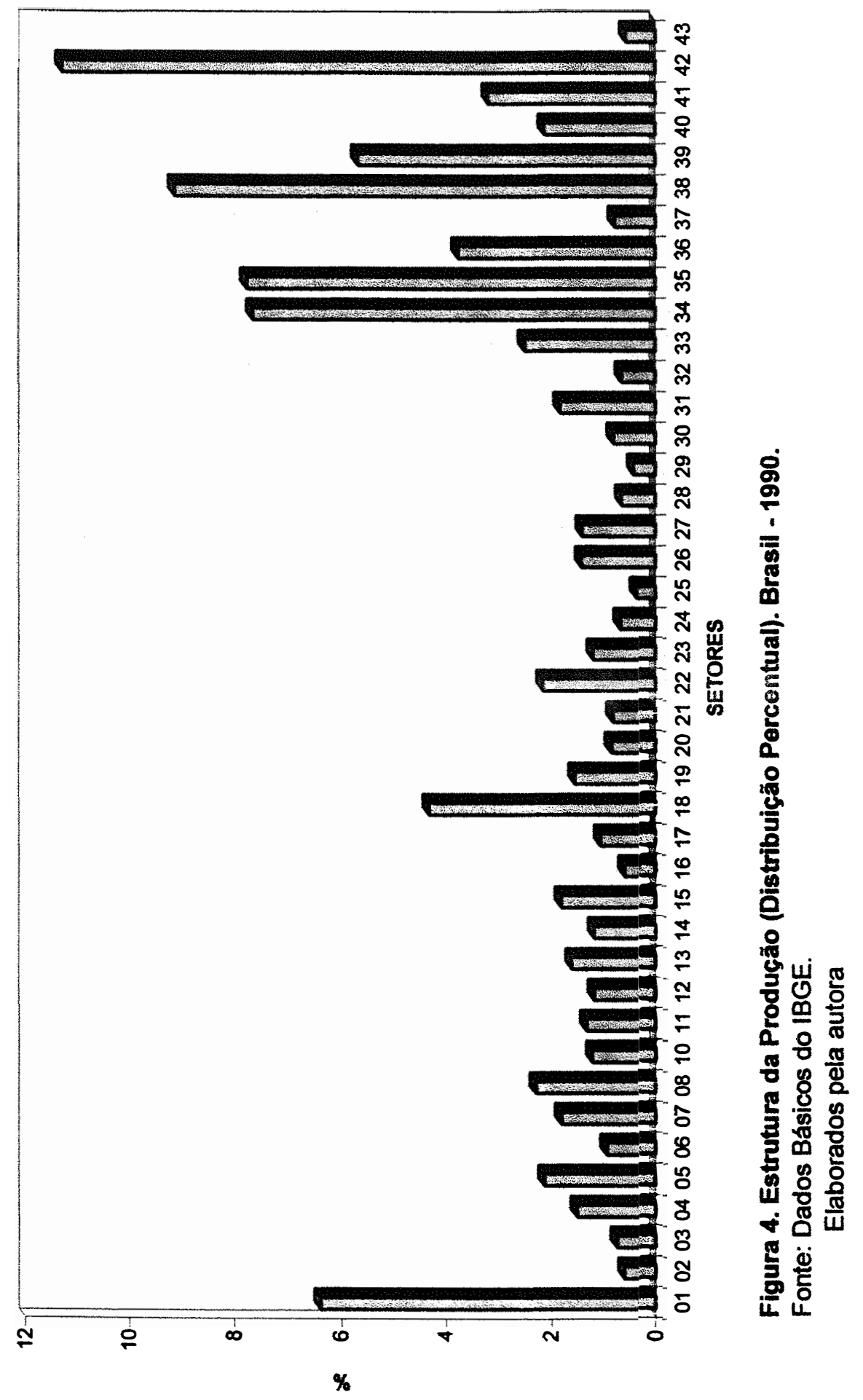


31 - Eabricação de Outros Produtos Alimentares) mostram tênues oscilações no período 1980-90.

Cabe ressaltar o avanço da participação do Grande Setor de Serviços 135 - Comércio, 36 - Transporte, 37 Comunicações, 38 - Instituições Einanceiras, 39 - Serviços prestados às Famílias, 40 - Serviços prestados às Empresas, 41 - Aluguel de Imóveis, 42 - Administração Pública, 43 Serviços Privados não Mercantis) sobre os demais a partir de 85, além do que o desempenho especial dos setores 38 Instituições Einanceiras e 42 - Administração Pública, que elevaram sua participação no total de produção de 4,98\% e 5,63\% em 1980, respectivamente, quando ocupavam a sétima e a sexta posição entre os 42 setores analisados, para 9,13\% e 11,28\% em 1990, respectivamente, quando passam a ocupar as segunda e primeira posições. A evolução desse setor constitui-se numa das principais características do processo de desenvolvimento dessa década. Os valores estão expressos como proporção do valor bruto total da produção, gerado em cada atividade econômica.

Pela distribuição da produção entre os diversos setores nota-se que a produção do Brasil está basicamente concentrada nos setores de transformação e terciário, respondendo o primeiro por $38,60 \%$ e $\circ$ segundo por $44,27 \%$ da produção total em 1990. Em relação ao setor industrial observa-se uma tendência de perda de participação em relação aos demais a partir de 85 .

Cabe lembrar que no início dos anos oitenta houve uma brusca reversão na trajetória de crescimento seguida pela economia brasileira e esta mergulha numa grave crise.

Ometto et al. (1995) apresentam a seguinte síntese dos acontecimentos econômicos enfrentados pelo Brasil na década de 80: O PIB "per capita" que de 1970 a 1980 vinha se expandindo à taxa média de 6,1\% a.a. diminui 13\% entre 
1980 e 1983. A tímida recuperação apresentada no período de 1984-1989 leva o valor desse indicador apenas a retornar aos níveis observados no início da década.

As raízes dessa crise, que se manifesta inicialmente como uma crise de endividamento externo, mas que rapidamente passa a se traduzir no desajuste interno da economia, estariam nas politicas adotadas na década anterior, quando a opção pela manutenção do crescimento econômico após o primeiro choque do petróleo, e, mais do que isso, a busca do salto definitivo no aprofundamento do processo de substituição de importações, levaram o Estado brasileiro a assumir um padrão de financiamento baseado no crescente endividamento externo.

o segundo choque do petróleo em 1979 e o brusco aumento das taxas de juros internacionais verificado viriam a aprofundar a crise externa brasileira através de uma série de mecanismos: pelo salto nos juros da dívida, por reorientar os fluxos de capital preferencialmente para os EUA e Europa, e pelo seu impacto negativo sobre os preços relativos das "commodities", itens importantes da nossa pauta de exportação.

Após a moratória mexicana, com a paralisação da entrada de capital externo, a reciclagem da dívida passou a exigir a realização de saldos comerciais crescentes e um ajustamento brutal da política econômica dos países devedores.

Entretanto, tais superávits comerciais viriam a se traduzir em sérios desequilíbrios na economia brasileira, pois, na verdade o problema não se esgota na questão da transferência de recursos, mas se complica pelo fato de que os superávits são obtidos basicamente pelo setor privado, enquanto a responsabilidade da dívida é do setor público. (Wernec, 1986). Ou seja, os saldos gerados em dólar pelo 
setor privado deveriam ser transformados pelo governo em cruzeiros, pela emissão monetária ou pela colocação de títulos junto ao público, com os previsiveis efeitos inflacionários e/ou recessivos.

Em conseqüência, se aprofunda 0 endividamento do setor público pela capitalização dos juros da dívida, e a poupança privada vai crescentemente se colocando a serviço da rolagem da dívida pública, comprometendo o crescimento econômico.

o que agrava a situação é que a medida em que as expectativas que os agentes financeiros têm sobre a capacidade do governo saldar seus compromissos vão se tornando cada vez mais desfavoráveis, tais agentes passam a exigir que os títulos apresentem juros maiores e liquidez máxima, provocando a deterioração das condições de financiamento da dívida pública interna.

Assim, a transferência de recursos privados para 0 governo e deste para as economias centrais viria a se transformar num elemento profundamente desestabilizador, e - desajuste externo a se traduzir no desajuste interno da economia brasileira. A elevação das taxas de juros, além de resultar no agravamento das contas públicas, provocaria ainda a aceleração das taxas de inflação.

Resumindo a argumentação pode-se dizer que 0 período da década de 80 caracterizou-se por altas taxas de inflação, com o setor externo restringindo sensivelmente as possibilidades de crescimento da economia, e baixas taxas de crescimento econômico (média de 2,22\% no período 198090). Além disso, esgota-se o processo de industrialização via substituição de importações da economia brasileira iniciada na década de 50.

Nesse quadro econômico desfavorável $\circ$ setor serviços ganha considerável espaço com queda de 
participação tanto do setor agrícola como do industrial, tendência essa semelhante às economias industrializadas.

Além disso, a queda maior do setor industrial do que do setor agrícola pode encontrar explicação no tipo de ajustamento macroeconômico adotado na economia brasileira na década de 80. Ferreira $\mathrm{F}^{\circ}$. (1997), buscando interpretar esse fenômeno, constata que a indústria sofreu grande redução na demanda de seus produtos, principalmente nos segmentos voltados para a formação de capital na economia, ocasionados pelo ajustamento macroeconômico que reduziu a poupança agregada da economia e o investimento agregado. Evidencia, também, a influência da queda de preços dos fatores de produção agrícolas no período que contribuiu decisivamente no processo de desenvolvimento da agricultura brasileira a partir dos anos 80 .

Com relação à participação da demanda na produção total setorial (Tabela 10 e Figuras 5 a 7), a agricultura brasileira apresenta de modo geral baixa participação da demanda final na produção total, o que indica um alto grau de interligação setorial na economia, pois uma participação menor da produção total na demanda final implica numa utilização maior dos recursos dentro do processo produtivo. Cabe lembrar que isto pode ser devido às características da estrutura do setor agrícola. Pode-se observar também, que em 1990, com relação a 1985, excetuando o setor 28 Indústria de Laticínios, houve uma queda da participação de todos os setores da agroindústria (Versão 3), sobre o consumo total final. Quando tomados os setores 35 a 43, que se referem basicamente a serviços, mostra-se no decorrer do tempo uma importância cada vez maior destes setores dentro da estrutura de consumo final e da economia. 


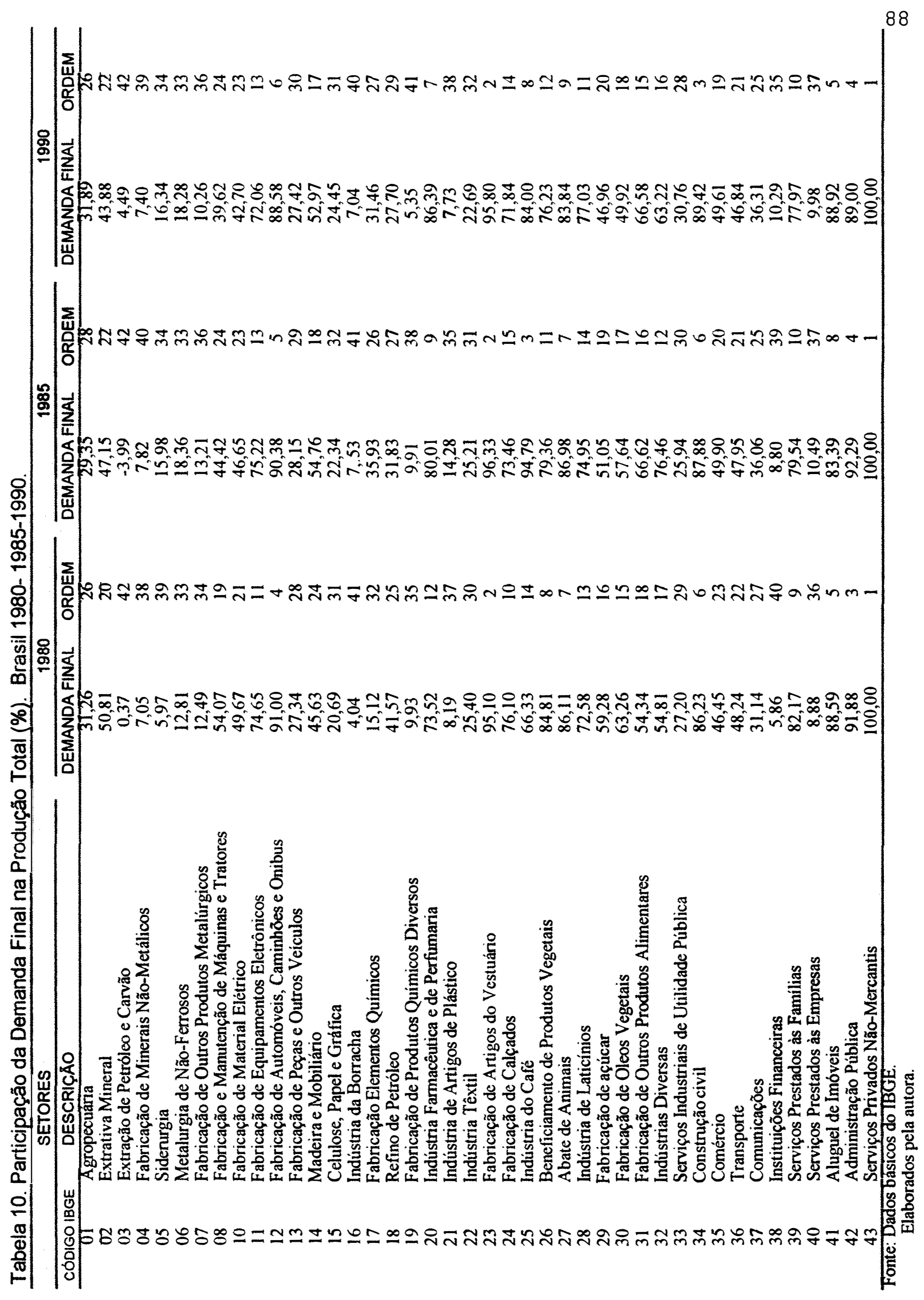




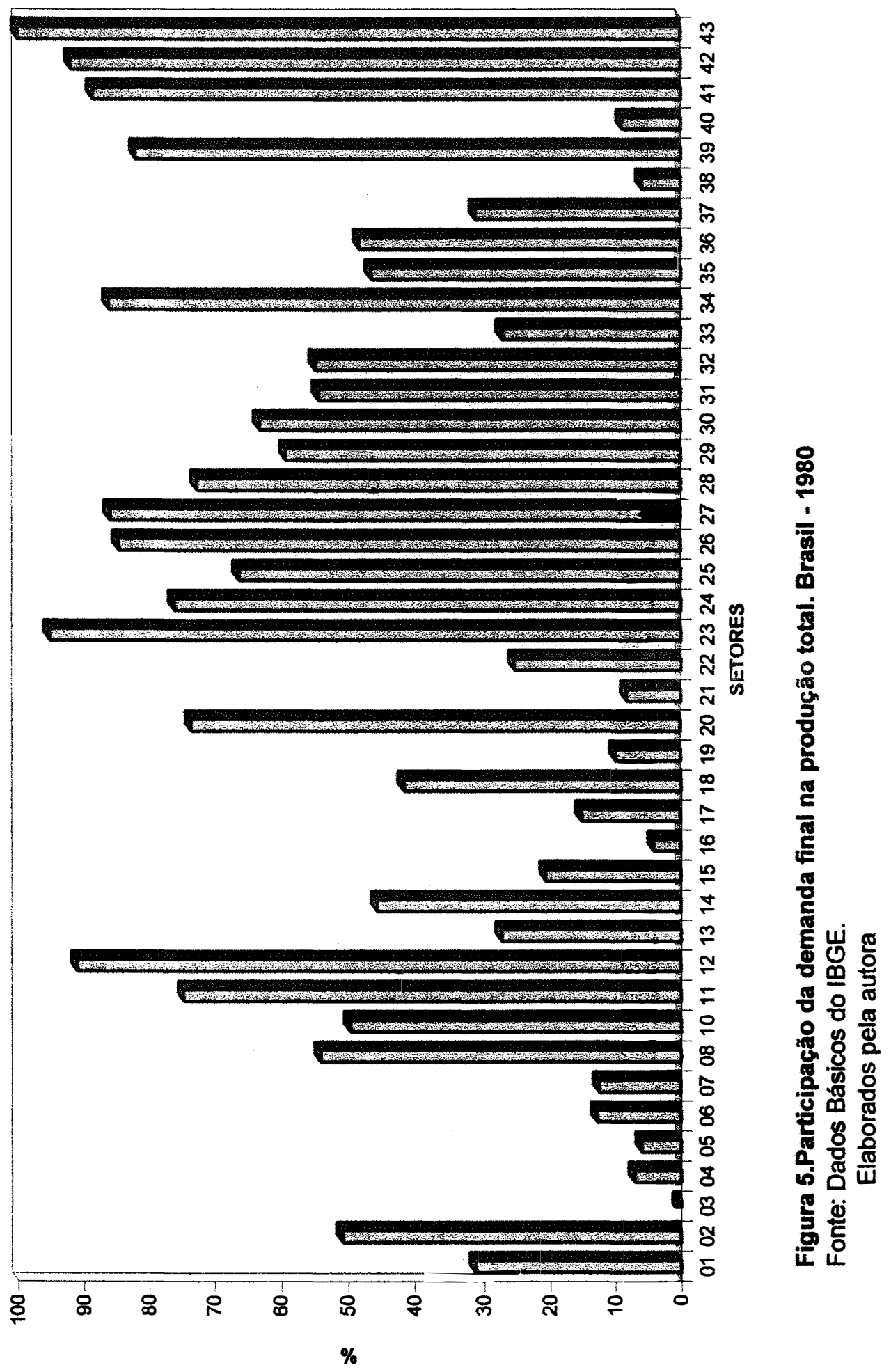




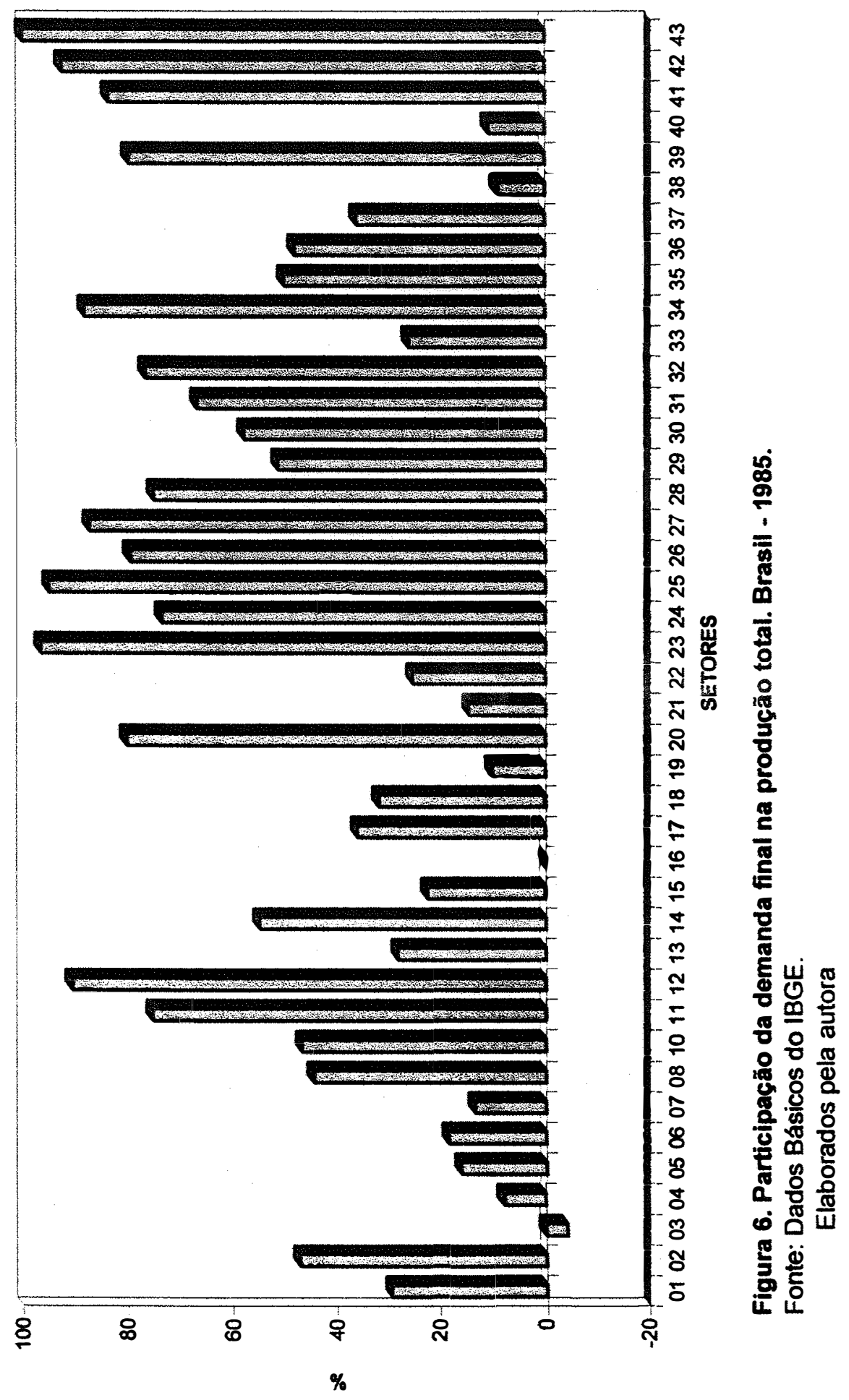




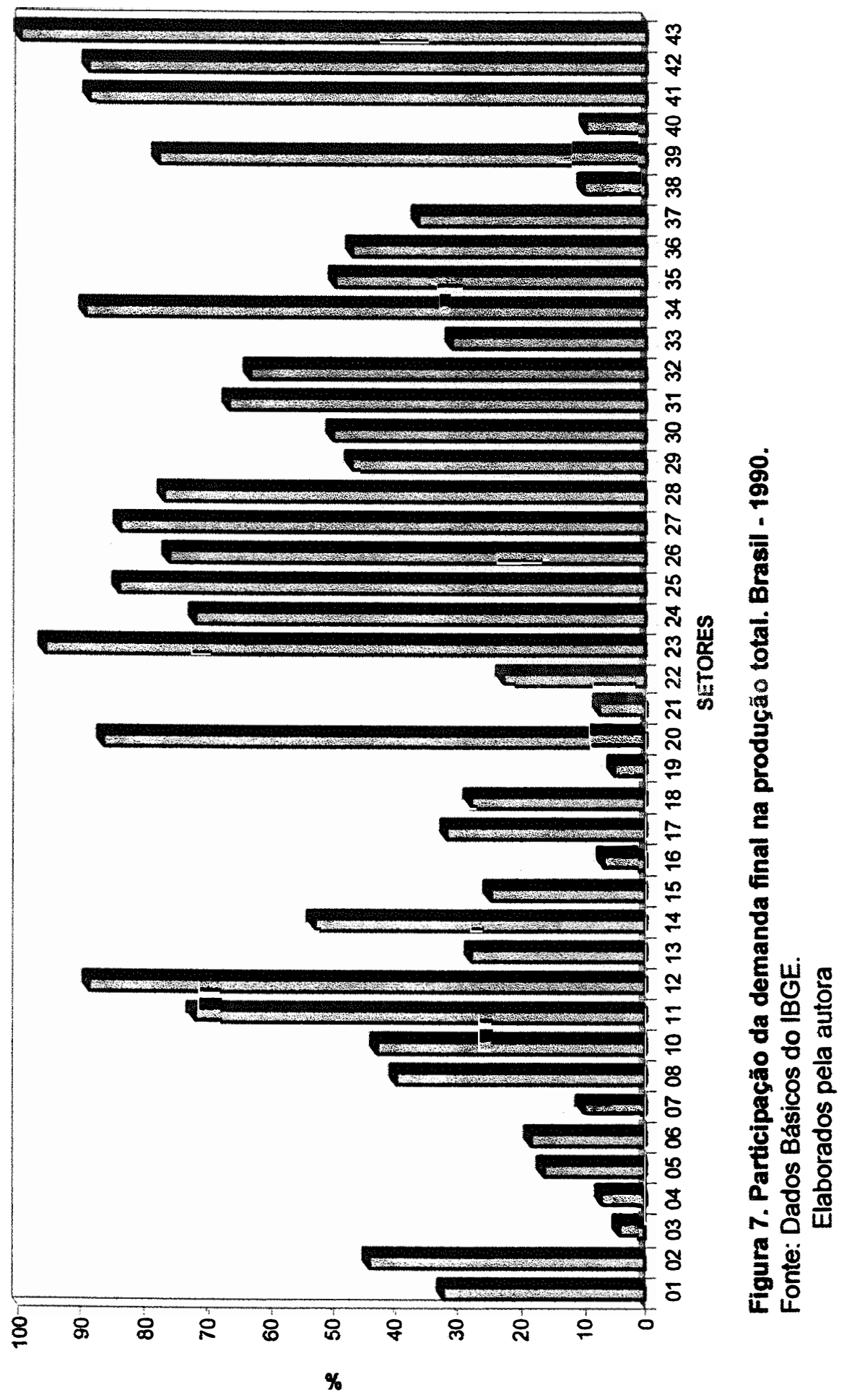


A participação dos insumos importados (Tabela $11 \mathrm{e}$ Figuras 8 a 10) na produção total de cada setor mostra que os maiores coeficientes de importação referem-se aos setores industriais. Nota-se que as atividades 18 - Refino do Petróleo e 19 - Eabricação de Produtos Químicos Diversos (adubos e fertilizantes), setores diretamente ligados à Indústria para agricultura, são as que se destacam entre os setores industriais de maior utilização de insumos importados, indicando uma grande dependência indireta da agricultura com relação a insumos importados. Adicionalmente pode-se assinalar que os setores primário e terciário apresentam baixo índice de importação. De um modo geral, a agroindústria também apresenta baixo nível de importação sobre o volume da produção total, com exceção do setor 26 Beneficiamento de produtos vegetais em 1980. Observa-se, também, tendência de queda da participação das importações, - que provavelmente reflete uma mudança nos tipos de insumos utilizados.

Uma análise da participação dos salários na produção total (Tabela 12 e Eiguras 11 a 13) confirma a tendência observada em outros trabalhos abarcando diferentes períodos (Baer, Eonseca e Guilhoto, 1987; Guilhoto e Picerno, 1995) de que existe na economia brasileira, em geral, uma participação pequena dos salários e encargos sobre a produção total, principalmente para o setor industrial. Apesar da análise se basear na massa de salários e não no volume de mão-de-obra, a menor participação dos salários indica que essa economia está utilizando uma tecnologia capital intensiva. Verifica-se, também, uma participação maior dos salários no setor terciário. Para o setor primário, de 1980 para 1990, registra-se uma queda nos coeficientes de salário. 


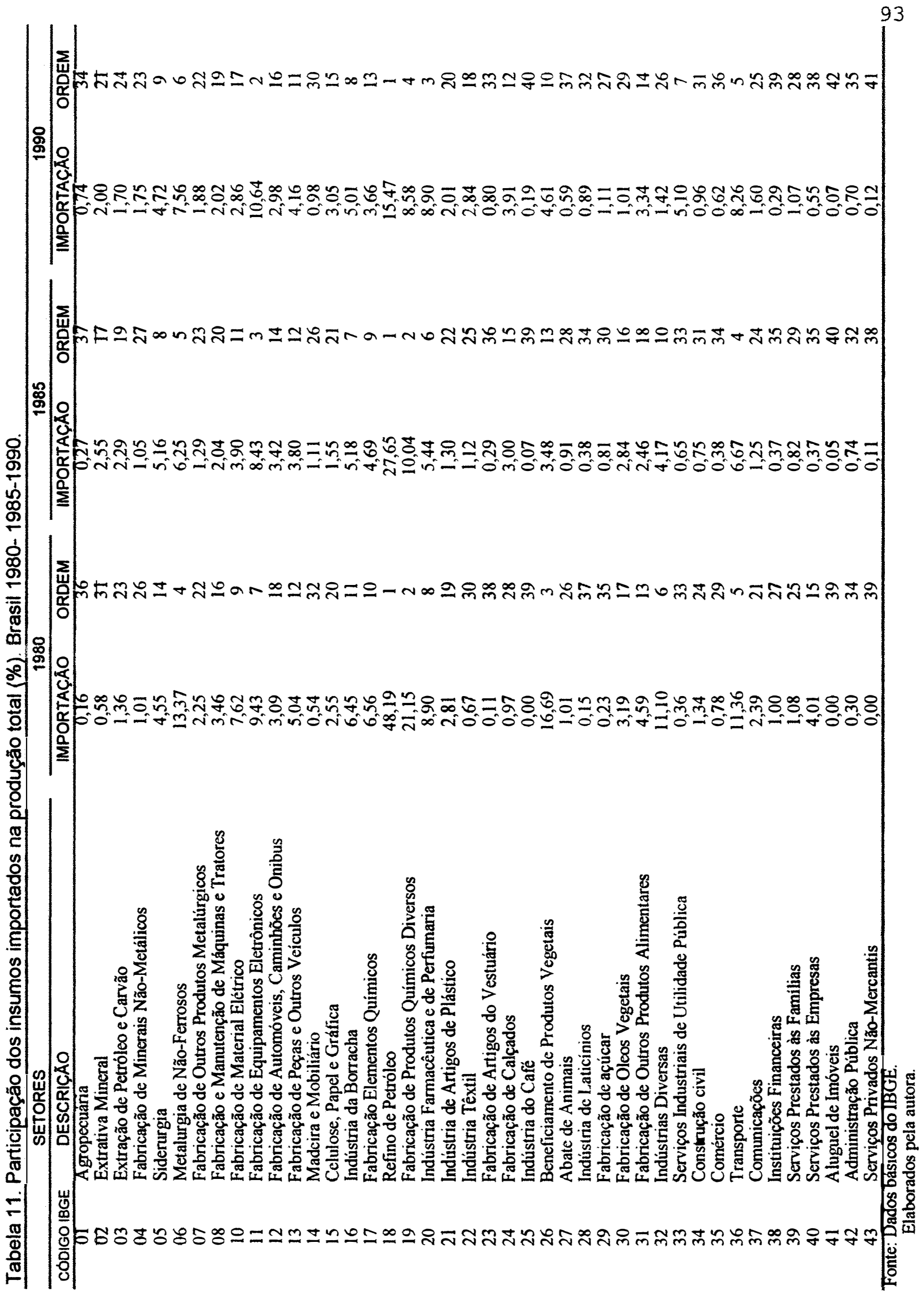




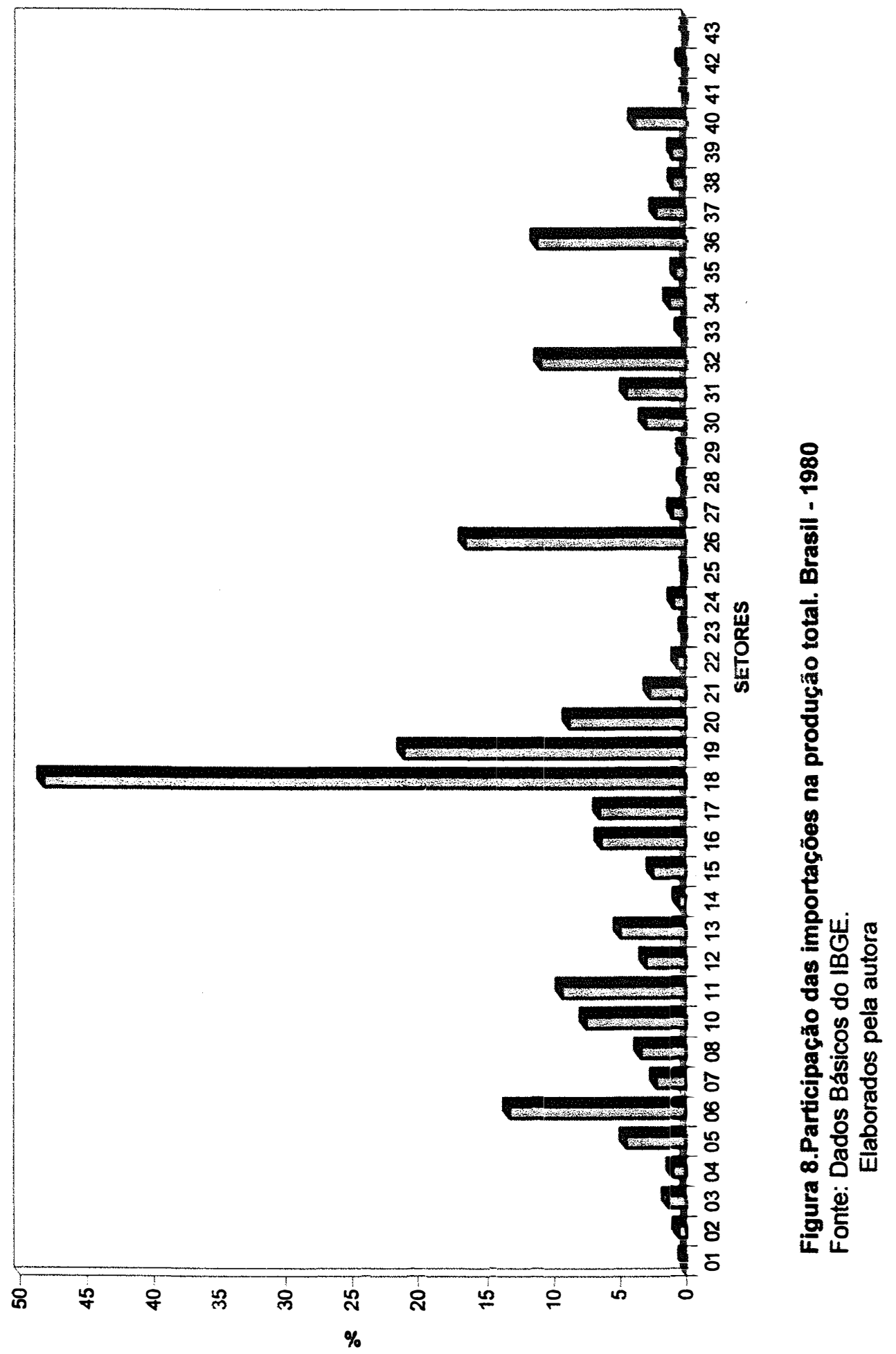




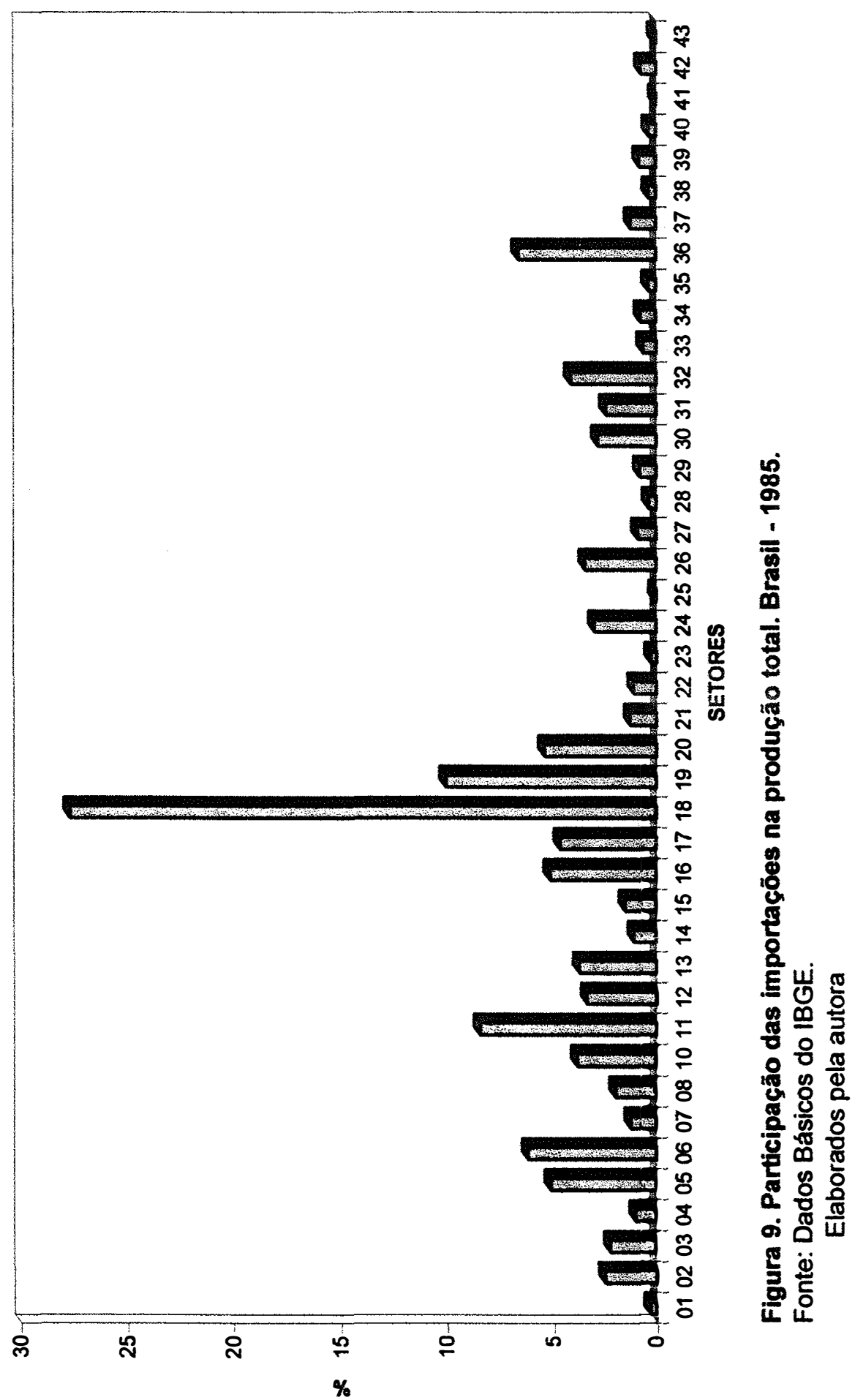




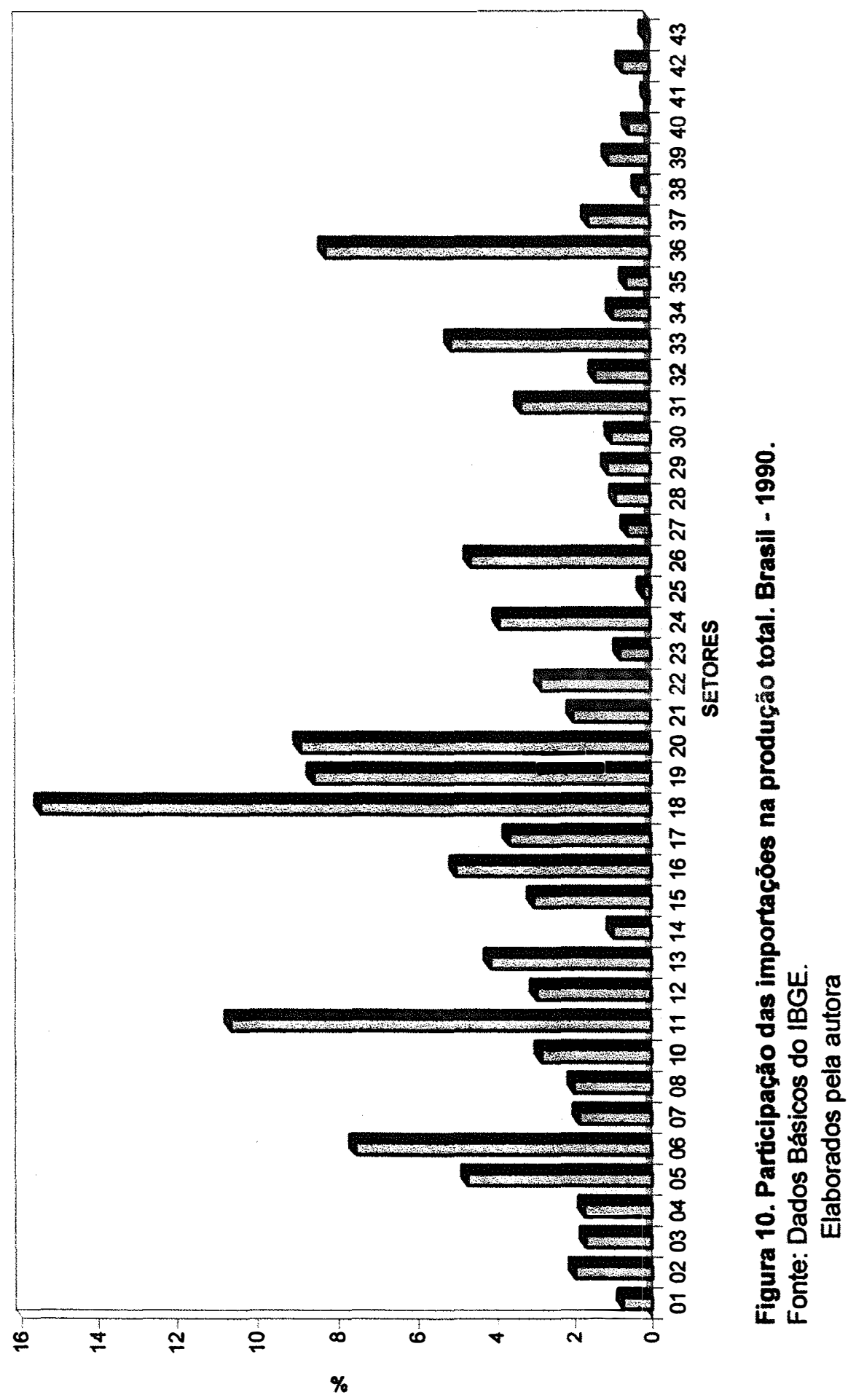




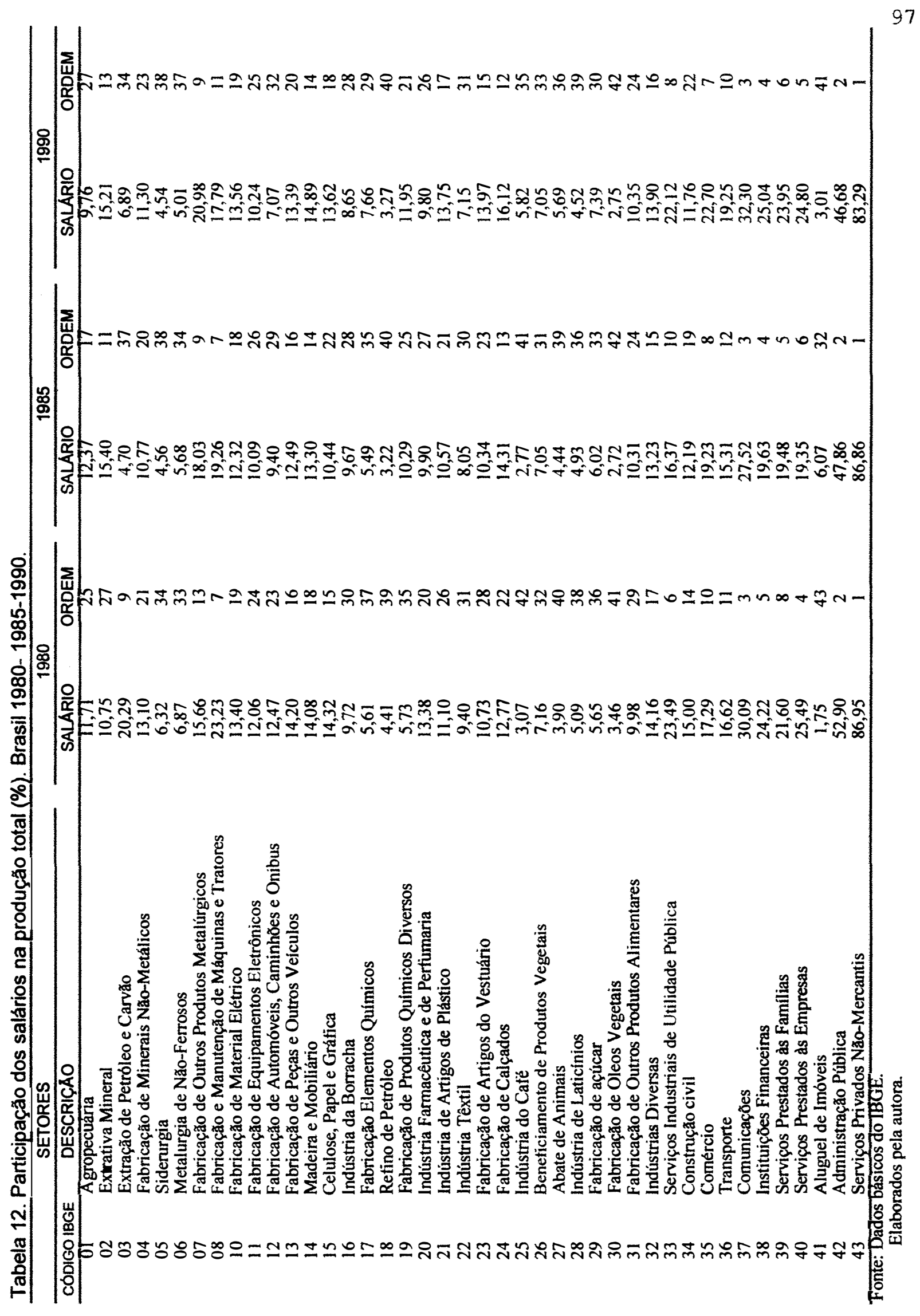




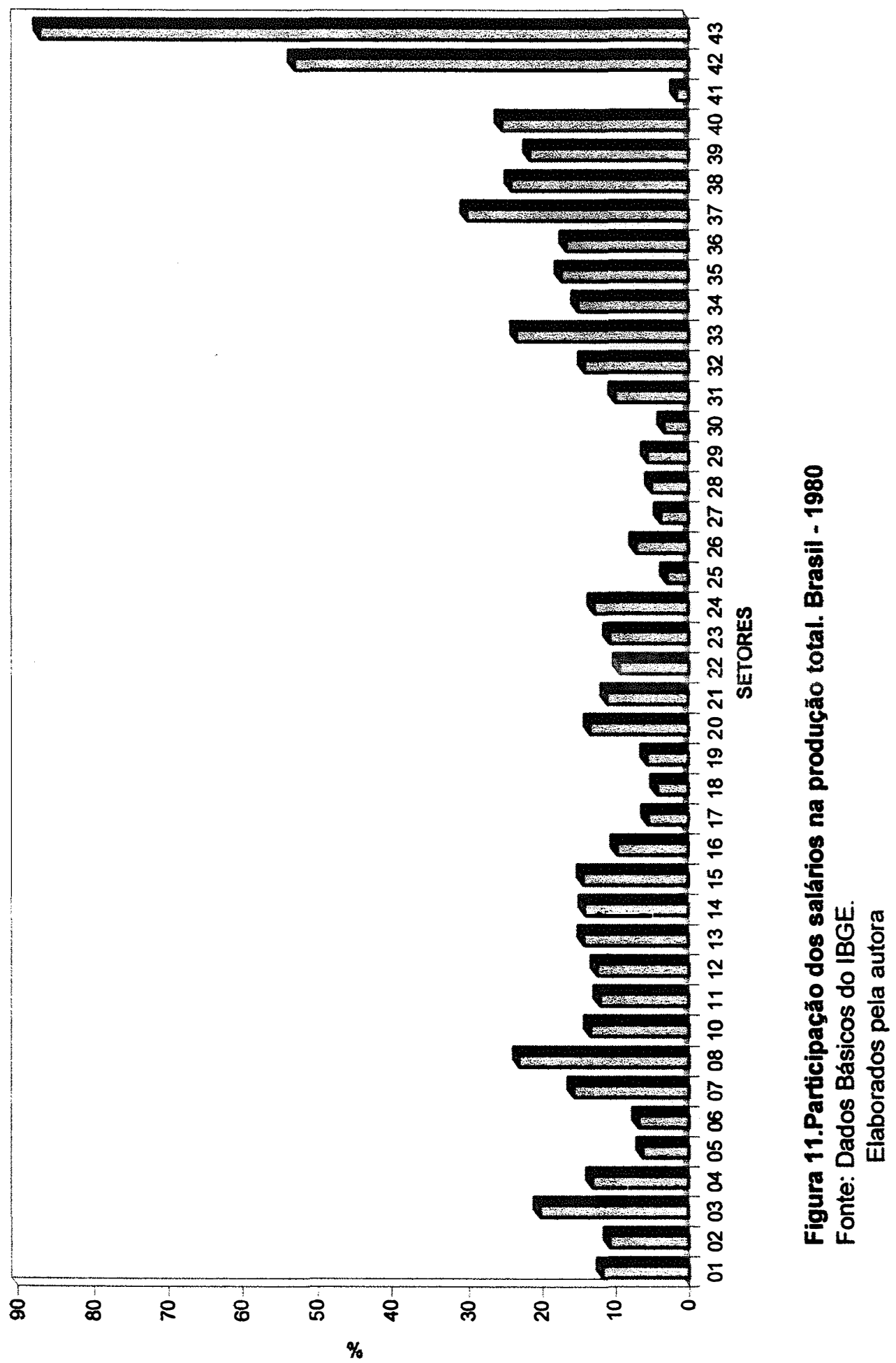




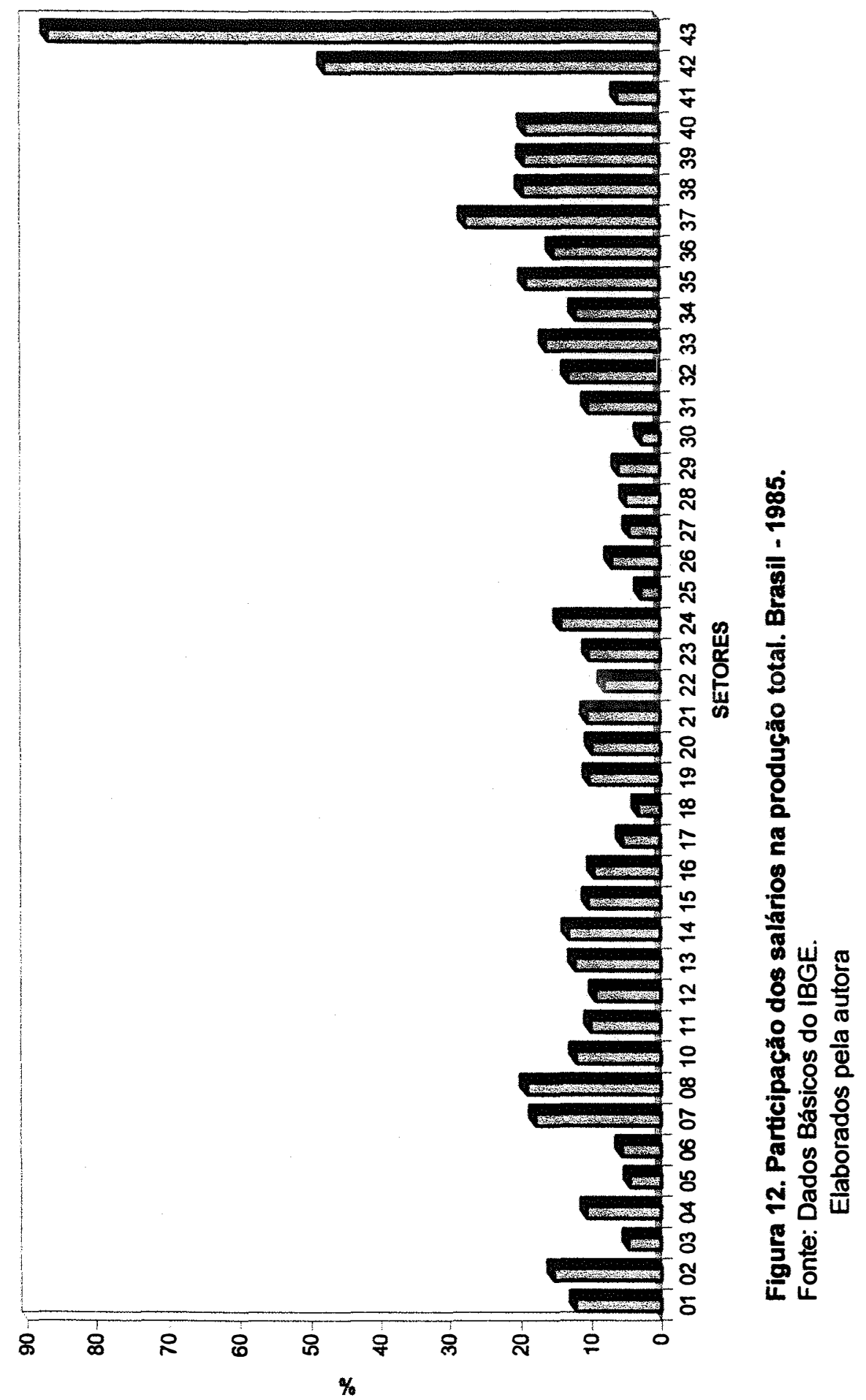




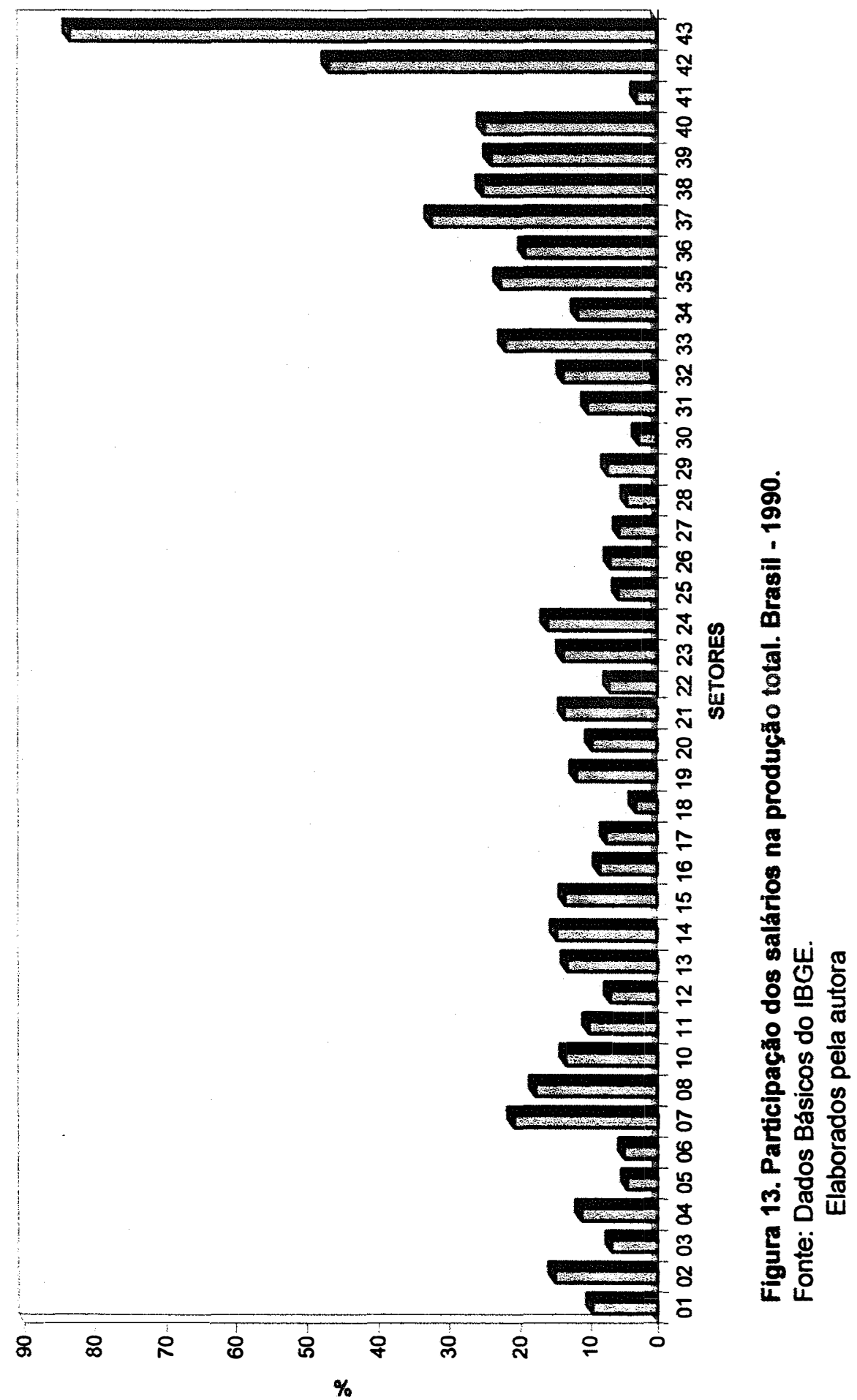




\subsection{2 Índices de ligaçōes interindustriais e setores-chave}

Conforme já mencionado anteriormente os índices de ligação para trás, segundo Rasmussen (1956) e Hirschman (1958), retratam a importância dos diferentes setores como demandantes de insumos dos outros setores da economia. Por sua vez, os indices de ligação para frente revelam os setores cujas produções são altamente utilizadas pelos demais setores no processo produtivo. Este enfoque é utilizado para se determinar os setores com maior poder de encadeamento dentro de uma economia, sendo que valores maiores que 1 indicam setores acima da média.

As Tabelas 13 e 14 apresentam os índices de ligação para trás e para frente em 1980, 1985 e 1990. Considerandose os cinco setores com os maiores indices de ligação para trás tem-se os setores 5 - Siderurgia, 12 - Fabricação de Automóveis, Caminhões e Ônibus, 25 - Indústria do Café, 28 - Indústria de Laticínios, e 30 - Eabricação de óleos Vegetais ocupando as cinco primeiras posições para os três períodos. Vê-se que entre esses segmentos os de produtos alimentares têm um peso importante nas relações da economia brasileira compondo três das cinco principais atividades. Com relação aos indices de ligação para frente destacam-se os setores 1 - Agropecuária, 5 - Siderurgia, 18 - Refino do Petróleo, 35 - Comércio, e 36 - Transporte ocupando posições chave nos três períodos. Deve-se mencionar a relevância da Agropecuária que apresenta índice de ligação superior a 3 referindo-se a primeira posição tanto em 80 como em 85 e 90. É interessante observar ainda que, a ordem dos setores entre os períodos analisados não sofreu maiores alterações. 


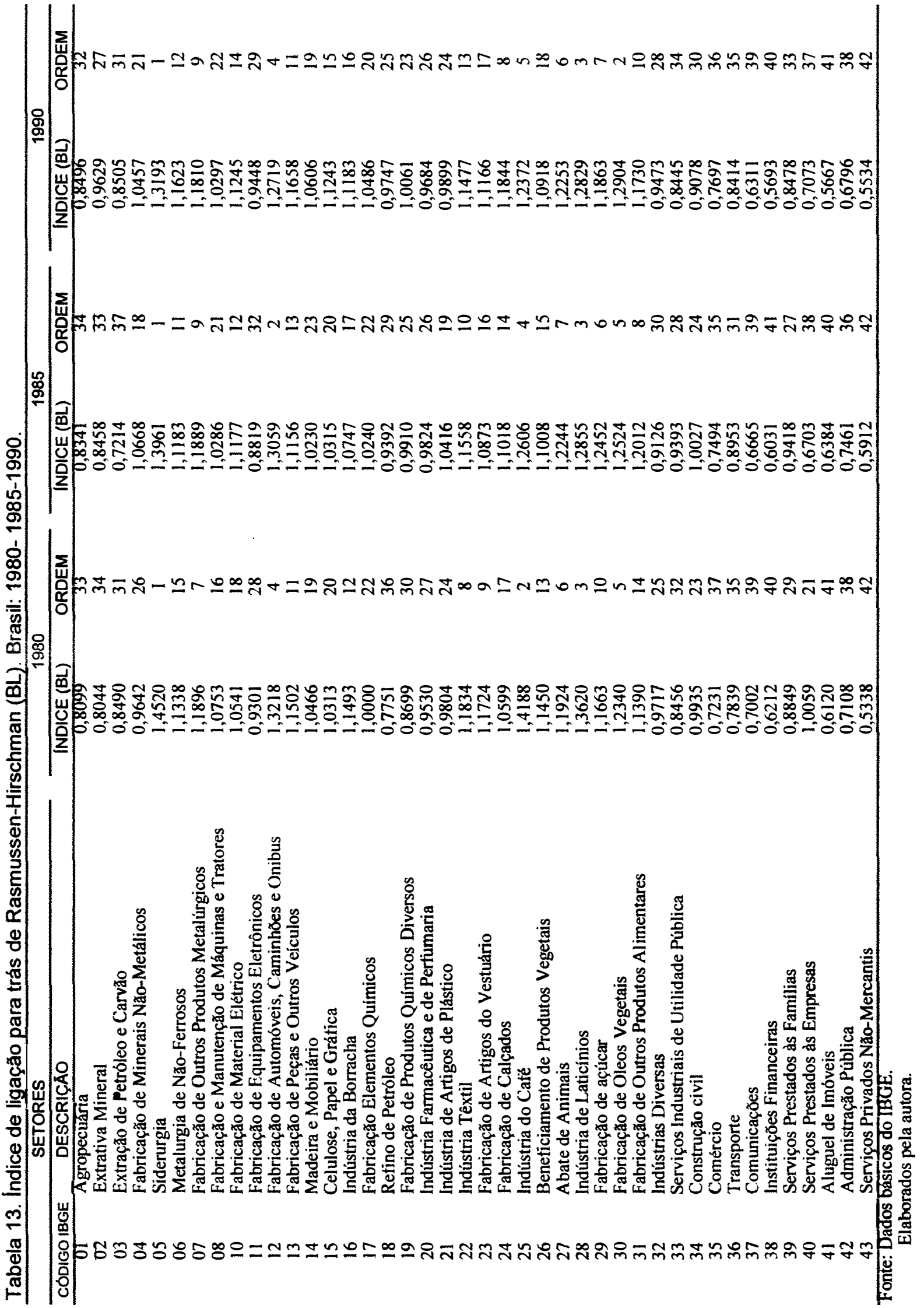




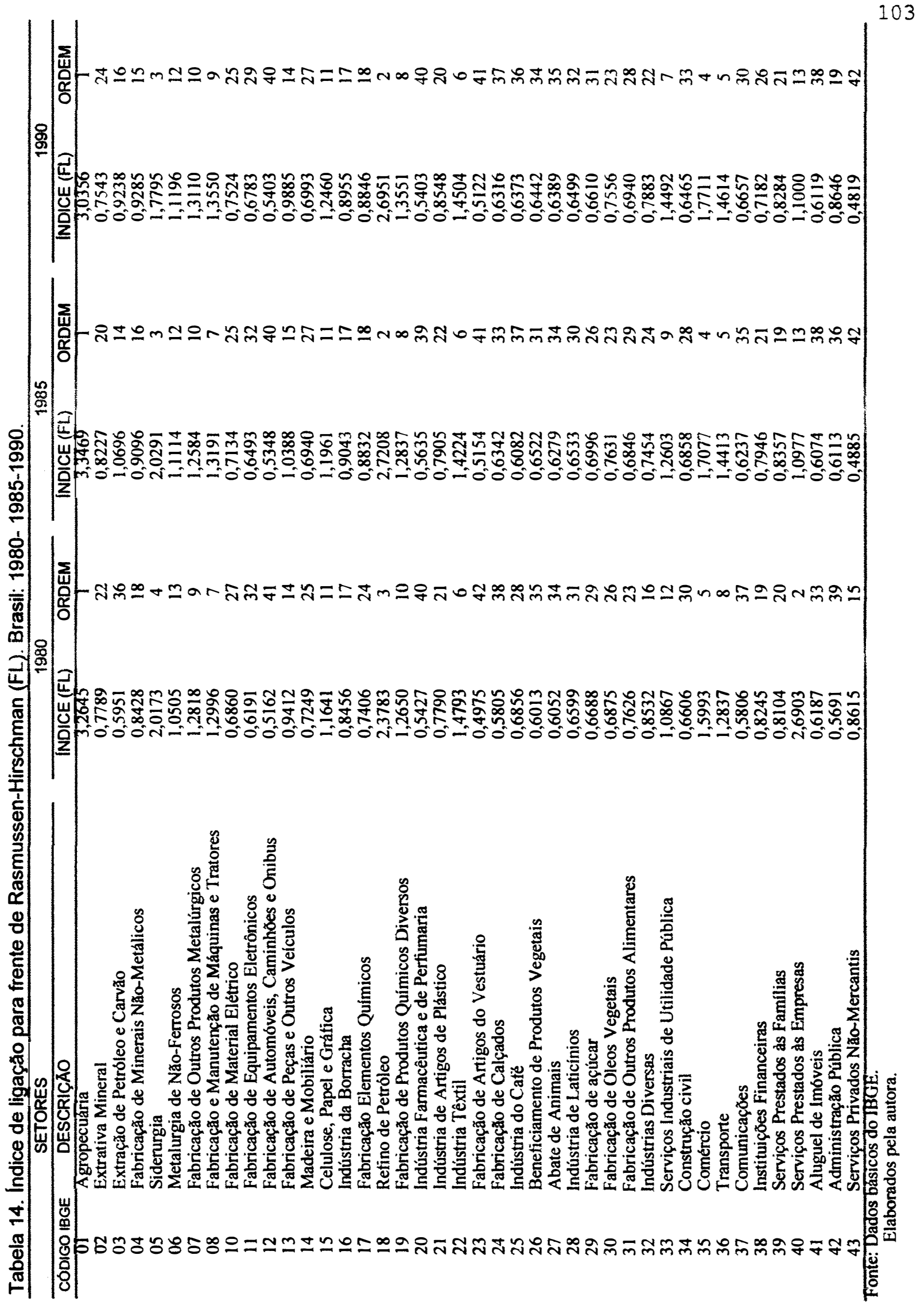


Por sua vez, os coeficientes de dispersão dos indices de ligação para trás (Tabela 15) mostram-se mais elevados para os segmentos do grande agregado serviços: 37 - Comunicações, 38 - Instituições Einanceiras, 41 - Aluguel de Imóveis; 43 - Serviços Privados Não Mercantis e para o setor 33 - Serviços Industriais de Utilidade Pública. O setor 1 - Agricultura apresenta, também, valor relativamente alto de dispersão. Desta feita, um impacto de uma variação de produção nestes setores estimularia os demais de maneira desigual se concentranoio em policos setores. Em relaçăo a Agroindústria (Versão 3) observa-se que na quase totalidade dos setores componentes os coeficientes de variação dos índices são relativamente baixos, indicando um ramo bem articulado domesticamente (Para detalhamento da composição de agroindústria ver seção 3.4.3).

No que respeita aos coeficientes de dispersão dos índices de ligação para frente (Tabela 16), observa-se que tanto o setor 1 - Agricultura como os setores 19 - Eabricação de Produtos Químicos Diversos - adubos e fertilizantes e 18 Refino do Petróleo, importantes setores componentes do Agregado Indústria Para a Agricultura, apresentam valores relativamente baixos de dispersão, significando que a demanda por estes setores ocorre de maneira uniforme, indicando assim ramos altamente interligados.

Usando como base a conceituação de índices de ligação para trás e para frente pode-se definir o conceito de setores chave. Segundo McGilvray (1977) são considerados setores chave aquelas atividades com ambos coeficientes (índices para trás e para frente) maiores do que 1 . Pelas Eiguras 14,15 e 16 podemos observar que, no caso brasileiro, para os períodos em análise temos as seguintes 


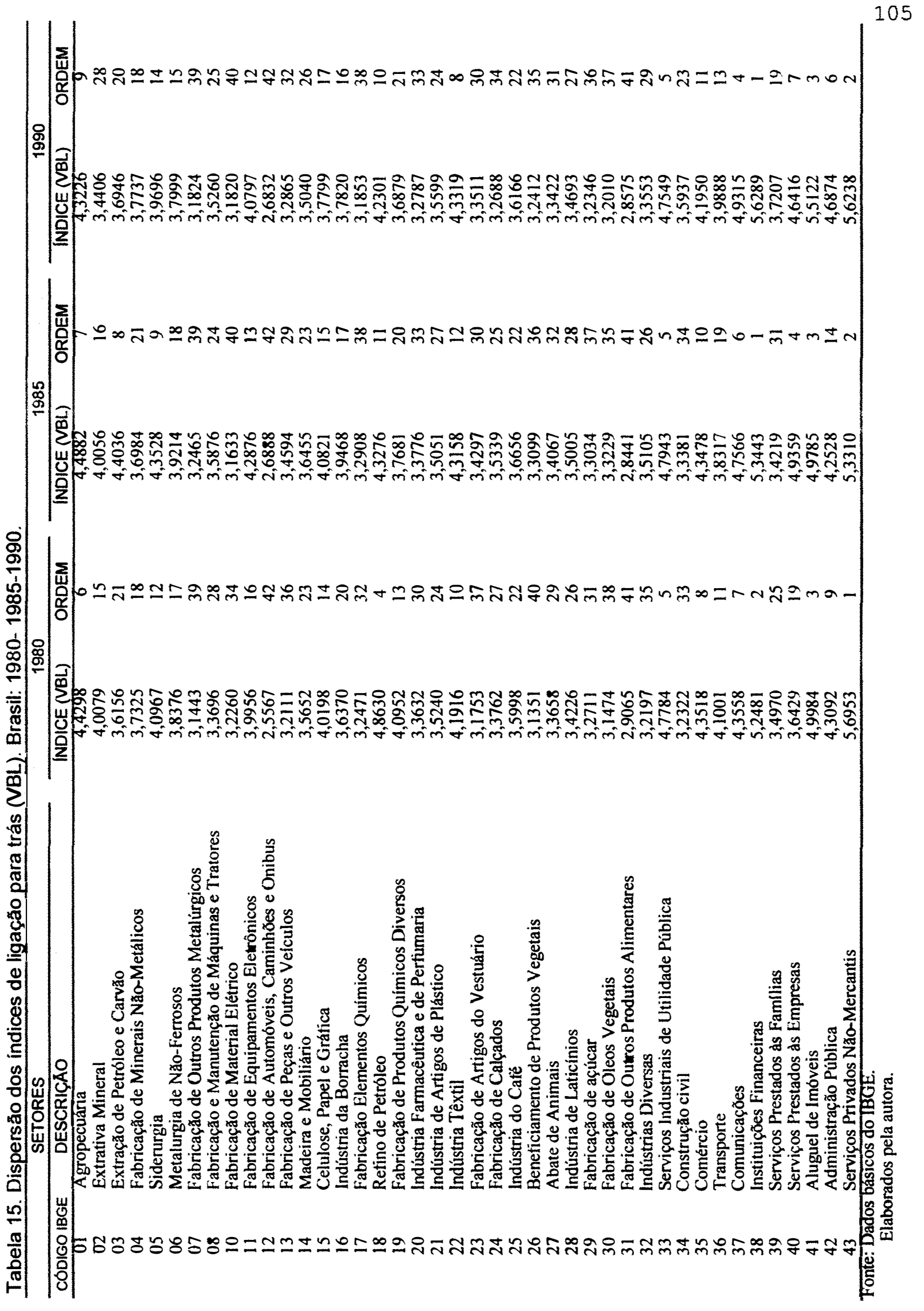




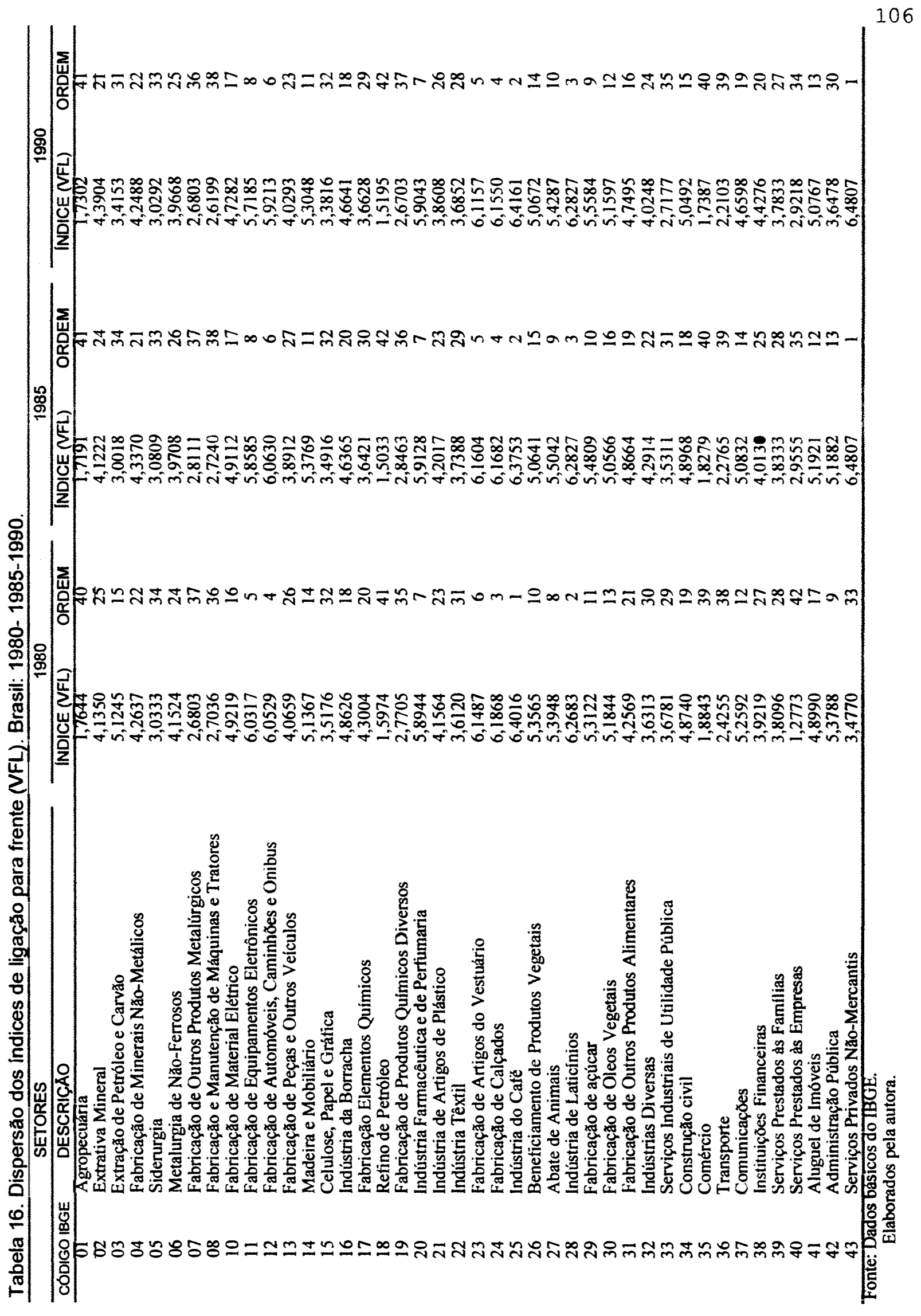




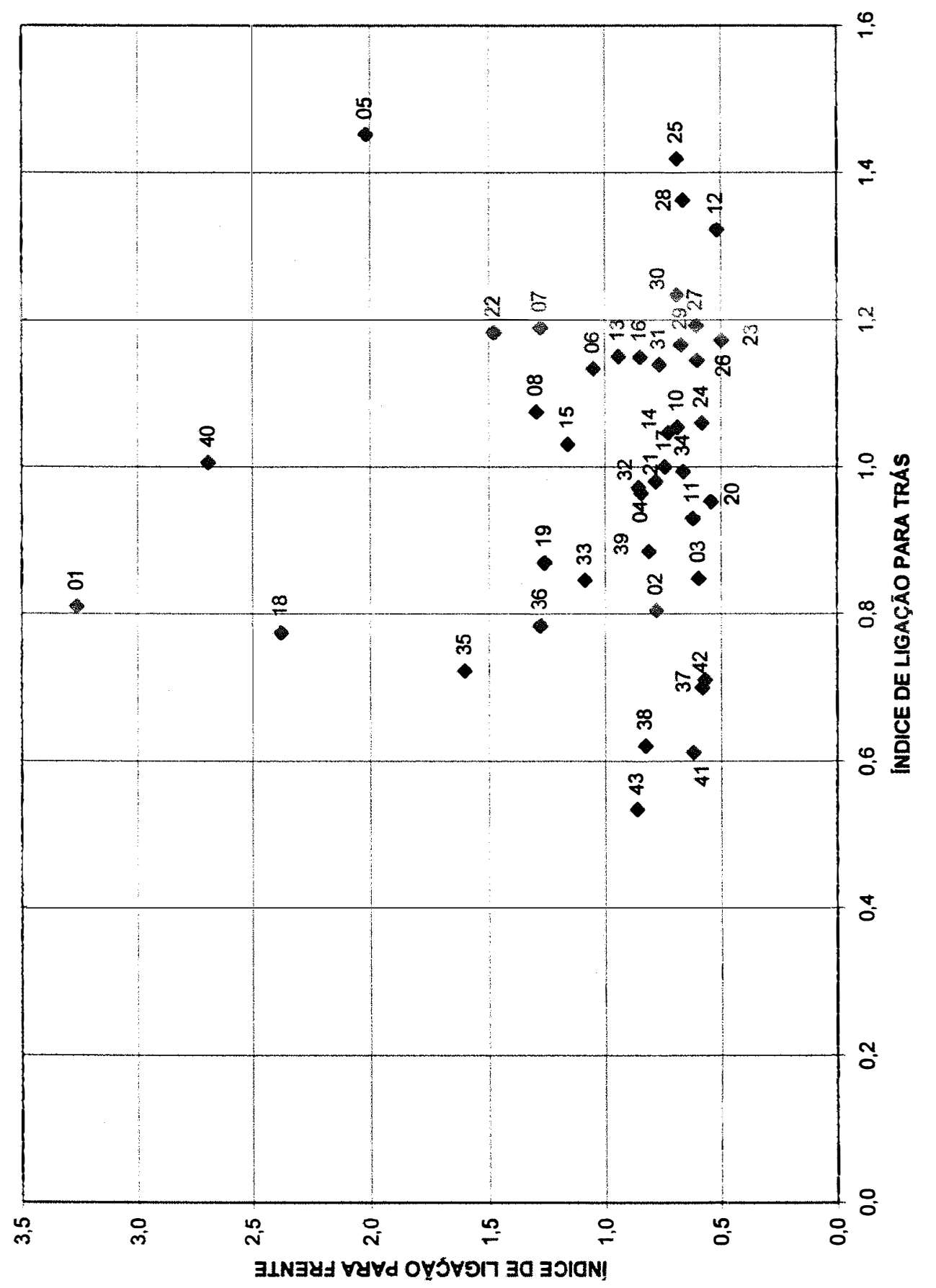

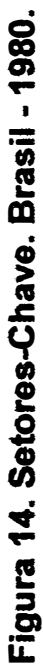




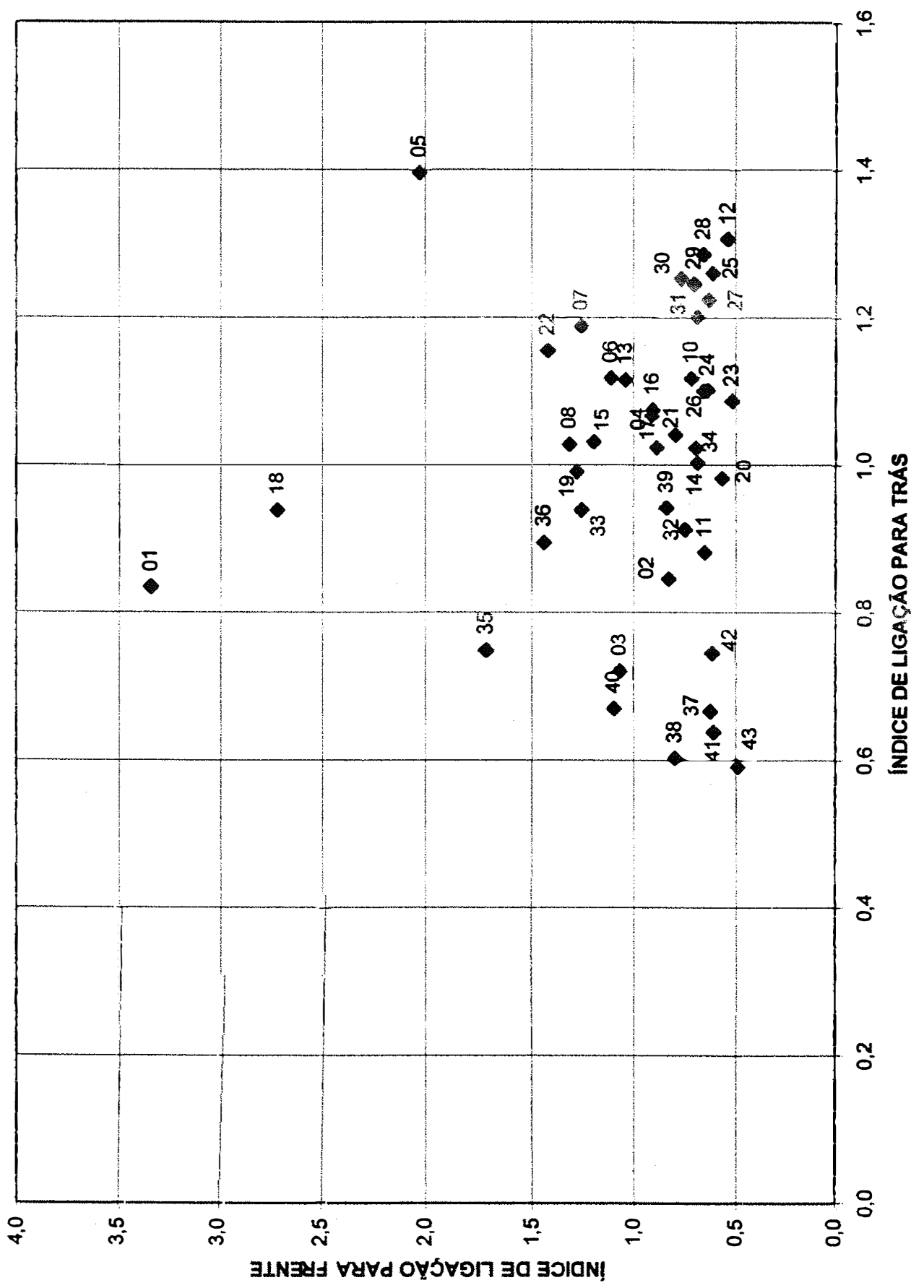

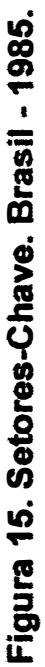




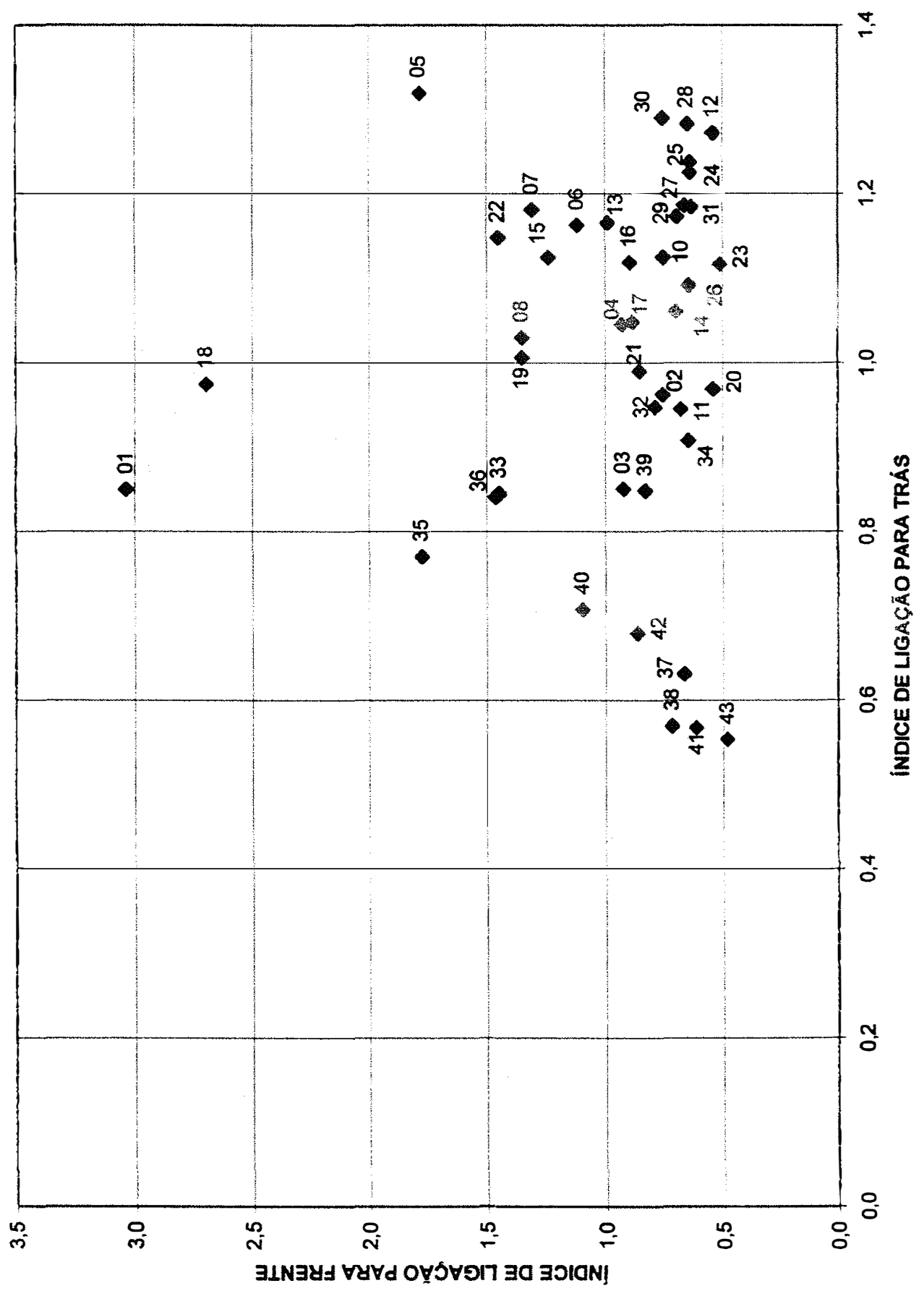

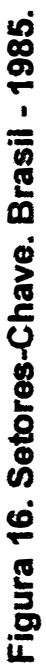


coincidências: 5 - Siderurgia, 6 - Metalurgia de não ferrosos, 7 - Eabricação de outros produtos metalúrgicos, 8 Fabricação e Manutenção de máquinas e tratores, 15 - Celulose, Papel e Gráfica e 22 - Indústria Têxtil. O problema desta definição é o de ser um critério mais restrito deixando de lado setores que apresentam altos valores em apenas um dos indices.

Para o caso de se adotar um conceito menos limitativo e estabelecer setores chave como aqueles que apresentam ou o índice de Iigaçăo para trás ou o indice de Lgaçăo para frente com valores maiores do que 1, corre-se o risco dessa classificação ser demasiadamente extensa.

Como hipótese alternativa para determinação dos setores chave há uma definição menos restrita, sugerida por Guilhoto e Picerno (1995), onde definem-se setores chave como sendo aqueles que apresentam os maiores índices de ligação para trás e para frente, assim como aqueles que satisfazem o conceito mais restrito de setor chave. Utilizando-se essa definição para selecionar os principais setores da economia, e estabelecendo como ponto de corte os cinco maiores índices, temos as seguintes coincidências entre 80-85 e 90: 1 - Agropecuária; 5 - Siderurgia; Metalurgia (6 - Metalurgia de não ferrosos; 7 - Fabricação de outros produtos metalúrgicos); Mecânica (8 - Fabricação e Manutenção de Máquinas e tratores; 12 - Fabricação de automóveis, caminhões e ônibus); 15 - Celulose, Papel e Gráfica; 18 - Refino do Petróleo; 22 - Indústria Têxtil; Produtos Alimentares 125 - Indústria do Café; 28 Indústria de Laticínios; 30 - Fabricação de óleos Vegetais): 35 - Comércio, 36 - Transporte.

Para 0 caso dos indices puros, os índices de ligações para trás e para frente são somados, de modo a gerar o 
índice total de ligações (Tabelas 17, 18 e 19) onde a agregação possibilita uma nova base para determinação de setores chave na economia. ${ }^{27}$

Os setores chave, no caso do enfoque dos índices puro total, em todos os anos de análise, são: 1 - Agropecuária; 18 - Refino do Petróleo; 34 - Construção Civil; 35 - Comércio e, em adição a estes, 40 - Serviços Prestados às Empresas em 1980, 36 - Transporte em 1985 e 39 - Serviços Prestados às Famílias em 1990. O setor agricultura perde posição relativa, passando do primeiro lugar em 1985 para o terceiro em 1990, enquanto o setor comércio avança para o primeiro lugar no mesmo período (Ver Tabela 19).

Quando se considera os cinco setores com os maiores indices de ligações para frente ao longo do tempo, tem-se que, para o indice puro, os setores mais importantes são: 1 - Agropecuária, 18 - Refino do Petróleo, 35 - Comércio, 36 - Transporte em 1980, 1985 e 1990 e, complementando a Iista, 40 - Serviços Prestados às Empresas para os anos de 1980 e 1990 e 3 - Extração de Petróleo e Carvão para 1985 (Ver Tabela 18). Do lado do enfoque de Rasmussen-Hirschamn, com exceção do setor 5 - Siderurgia, os resultados são idênticos aos obtidos no enfoque puro para os quatro setores coincidentes nos três períodos (Ver Tabela 14).

\footnotetext{
2? trabalho de Guilhoto, Sonis, Hewings e Martins (1994) que apresenta uma análise da estrutura produtiva da economia brasileira, respectivamente em 1959, 1970, 1975 e 1980, introduz o conceito de indice de ligação puro e faz um paralelo com as metodologias mais tradicionais oferecendo uma visão ampla do papel dos indices de ligaçōes interindustriais nas análises de insumo-produto.
} 


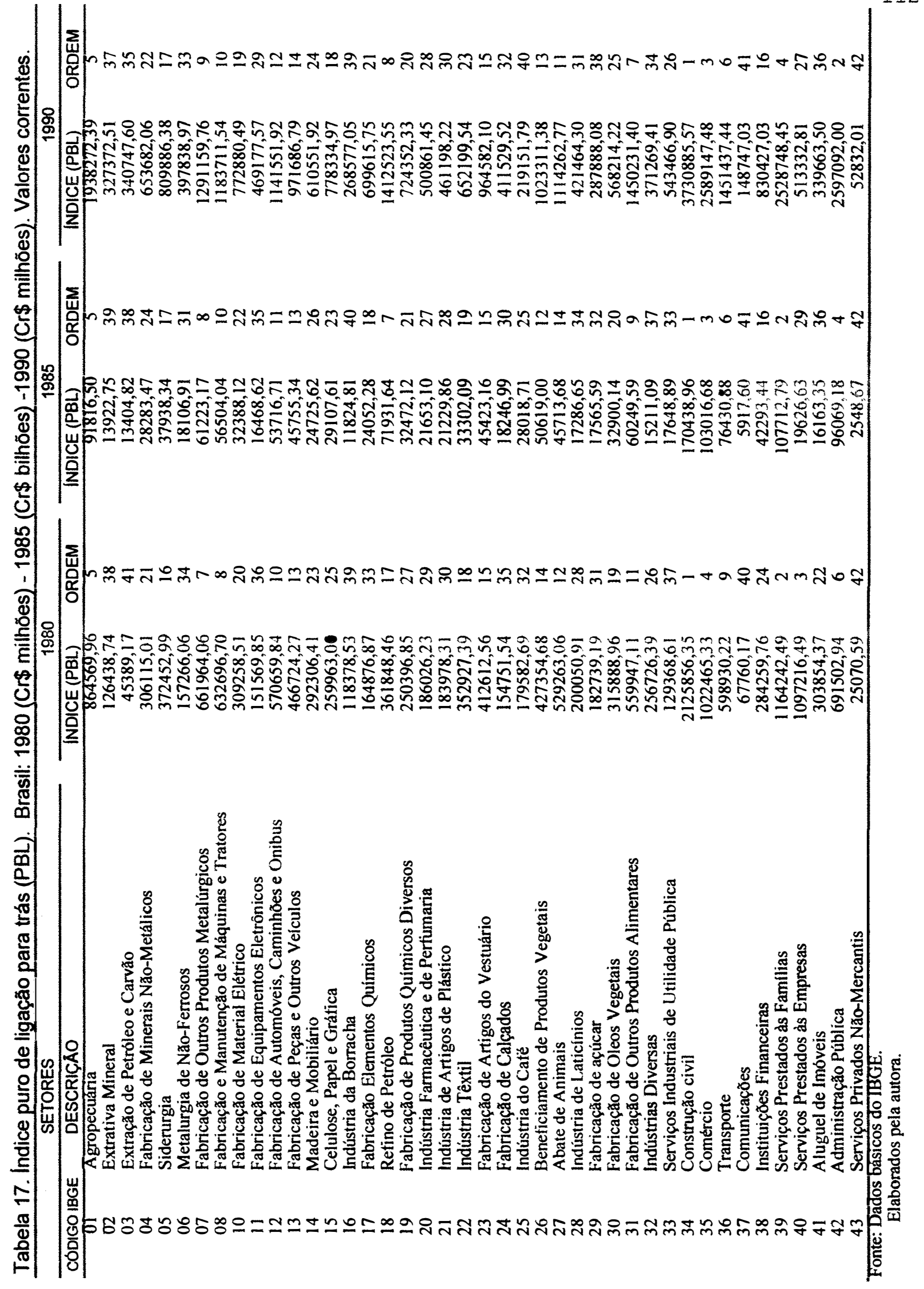




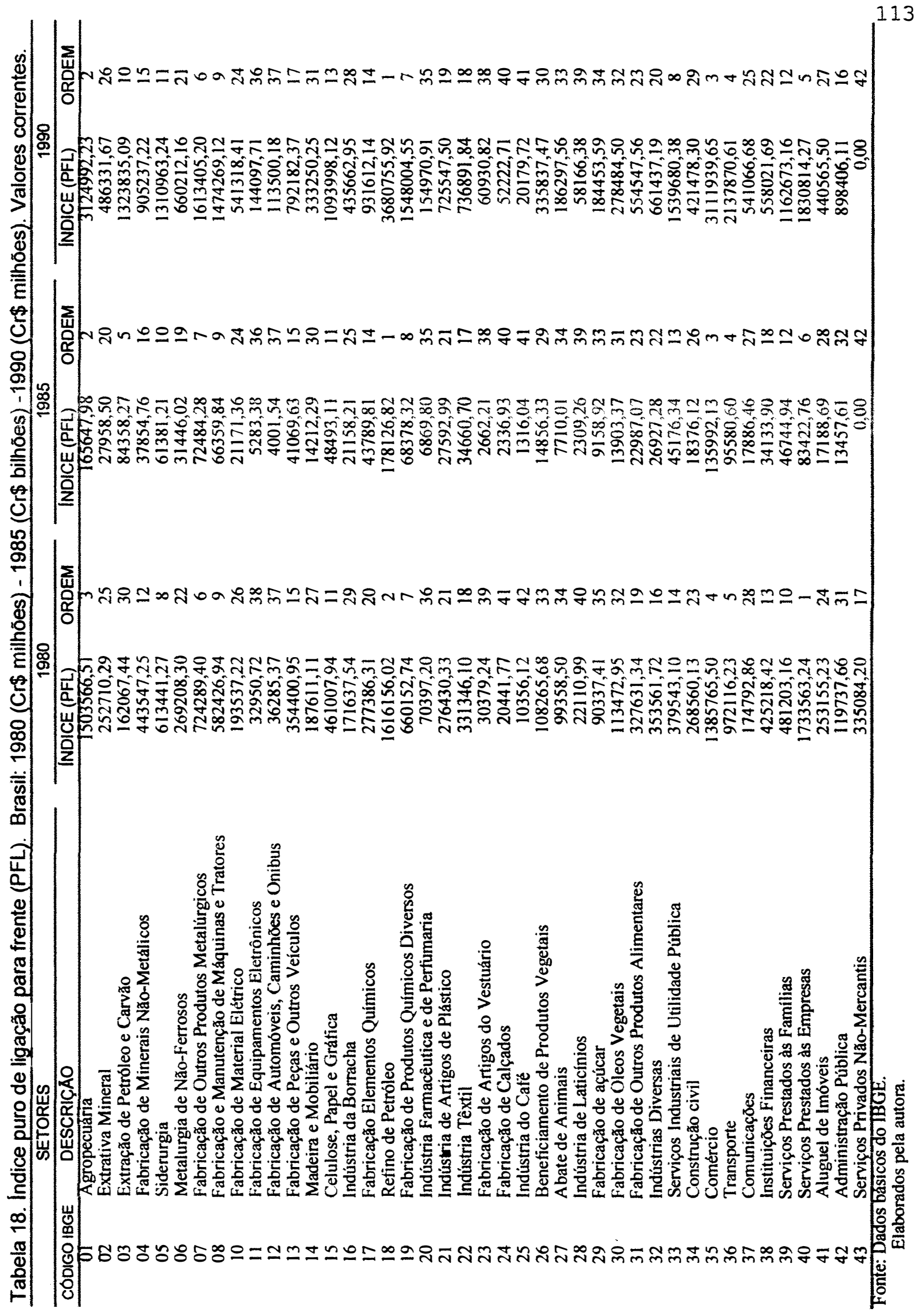




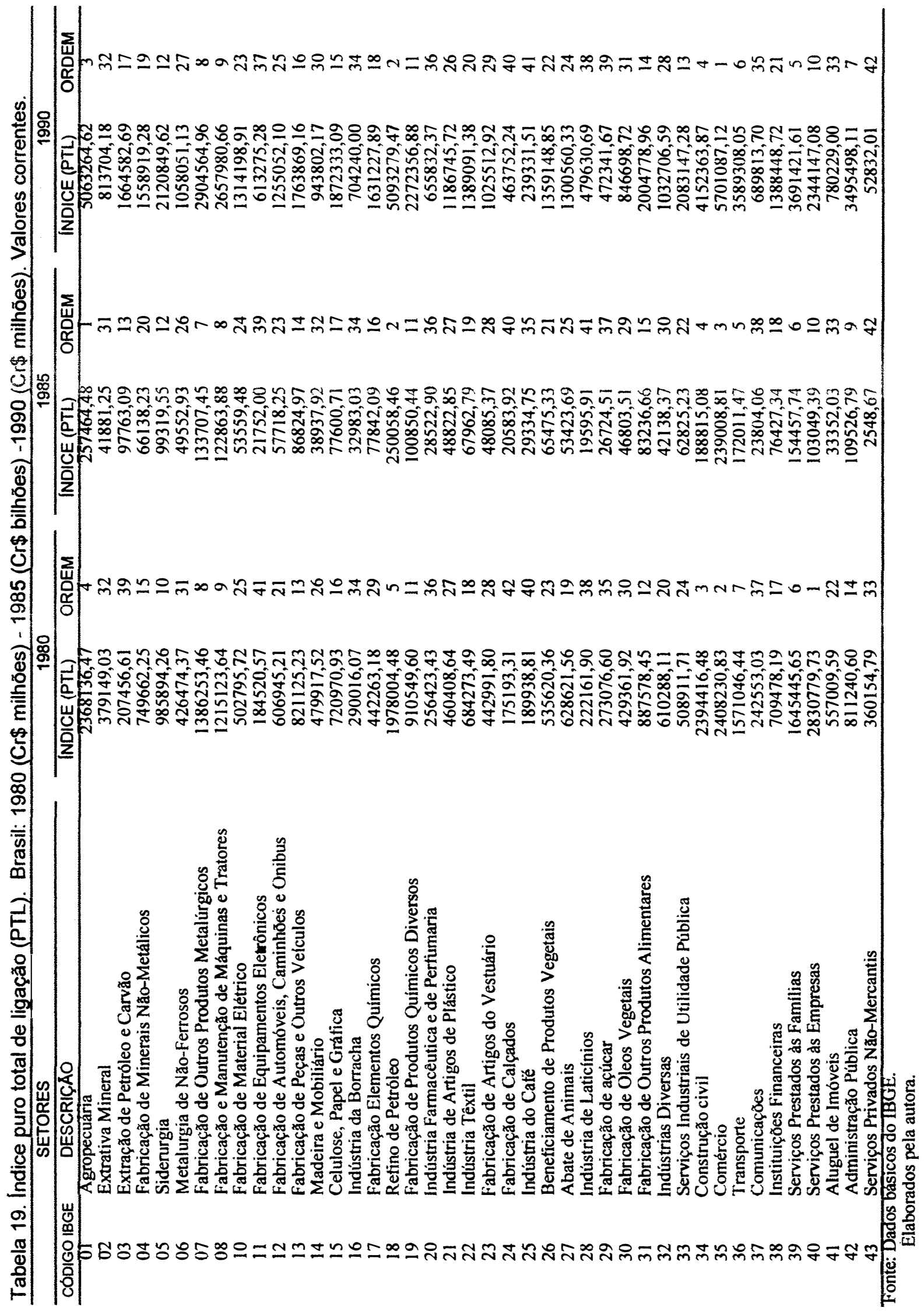


Na abordagem introduzida por Hewings et al. (1989), através da análise com a utilização da noção de campo de Influência, os resultados para os anos de 1980, 1985 e 1990 mostram que as relações na economia são dominadas basicamente pelos setores 5 - Siderurgia e 1 Agropecuária, enquanto o setor 22 - Indústria Têxtil aparece como o terceiro setor influente (Figuras 17, 18 e 19). Uma vez que esse conceito fornece o grau com que pequenas mudanças nos coeficientes de produção podem afetar - resto do sistema, os resultados apontam para a importância dos setores Siderurgia e Agropecuária nas relações de comercialização na economia brasileira, sendo capazes de gerar um grande impacto sobre o resto do sistema, conclusão em grande parte semelhante à encontrada por Guilhoto et al. (1994) que comprovou a mudança de estrutura produtiva brasileira entre 1959 e anos 70 onde 0 predomínio passa do setor duímica para o setor Metalurgia. Cabe ressaltar que a presente análise utiliza um grau de desagregação muito maior nas matrizes e o nível de agregação afeta o resultado dos índices.

Uma comparação dos resultados dos diversos índices mostra que, embora a metodologia de determinação de setores chave entre os diferentes enfoques apresentem diferenças básicas, podem e devem ser vistos como complementares entre si, propiciando uma visão mais ampla do sistema econômico. Como observa Guilhoto et al. (1994), a abordagem de Rasmussen-Hirschman e a de Campo de Influência levam em conta o comportamento da estrutura interna da economia, independente do valor da produção total, enquanto o Índice Puro analisa a estrutura produtiva levando em consideração os níveis de produção setorial. Para o autor, quando a 


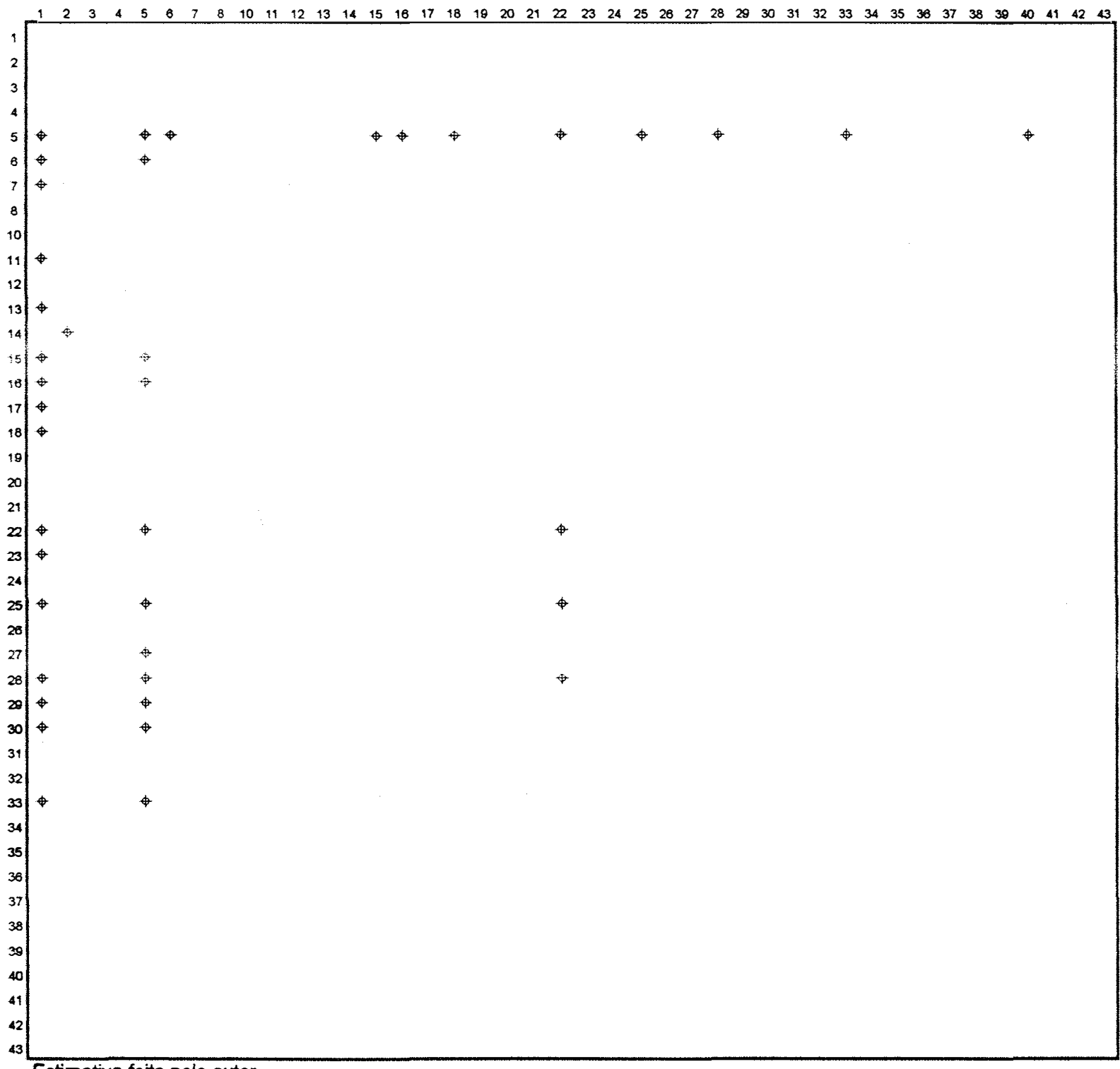

Estimativa feita pelo autor.

Figura 17. Coeficientes com o maior Campo de Influência. BRASIL - 1980. 


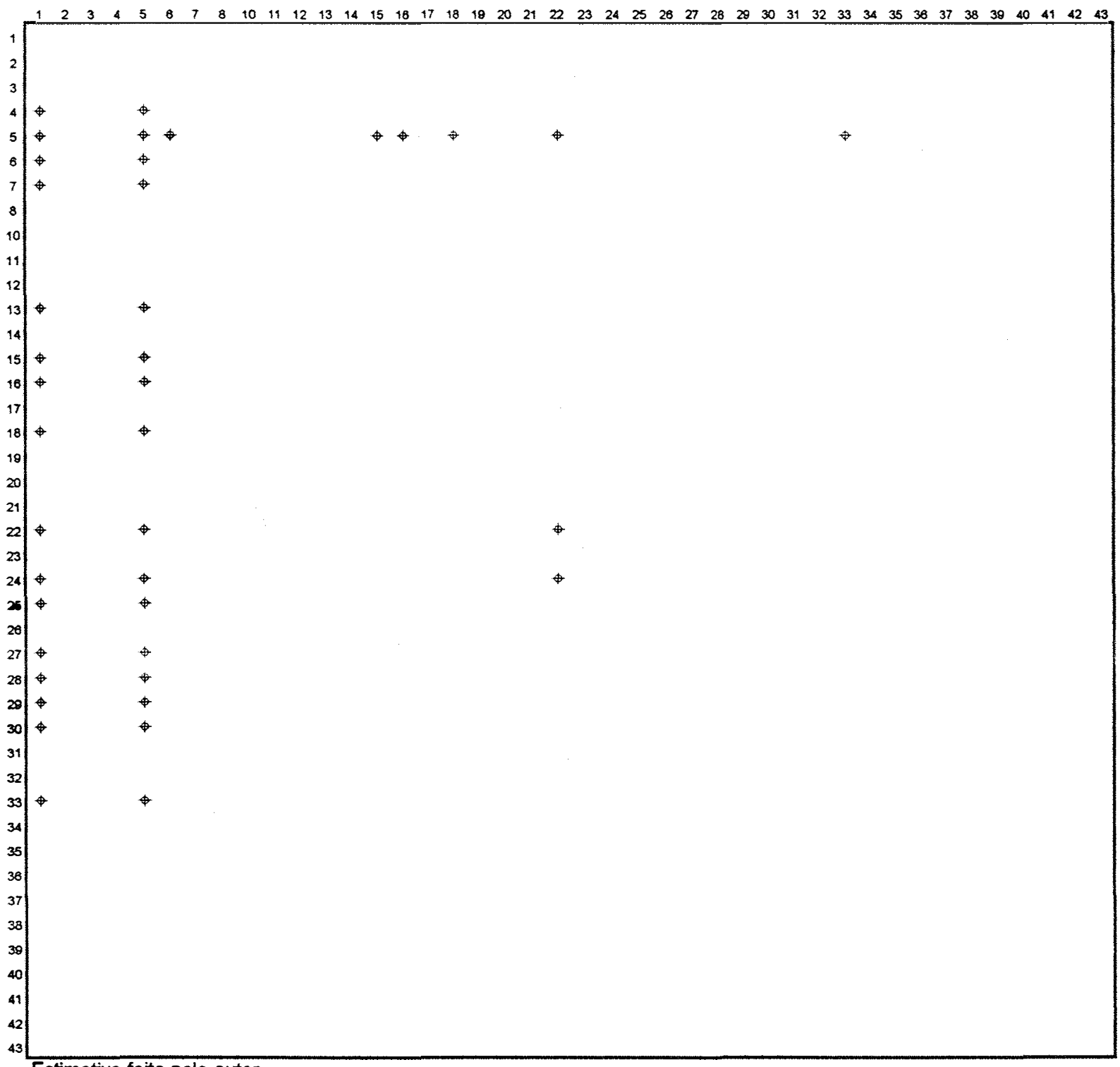

Estimativa feita pelo autor.

Figura 18. Coeficientes com o maior Campo de Influência. BRASIL - 1985. 


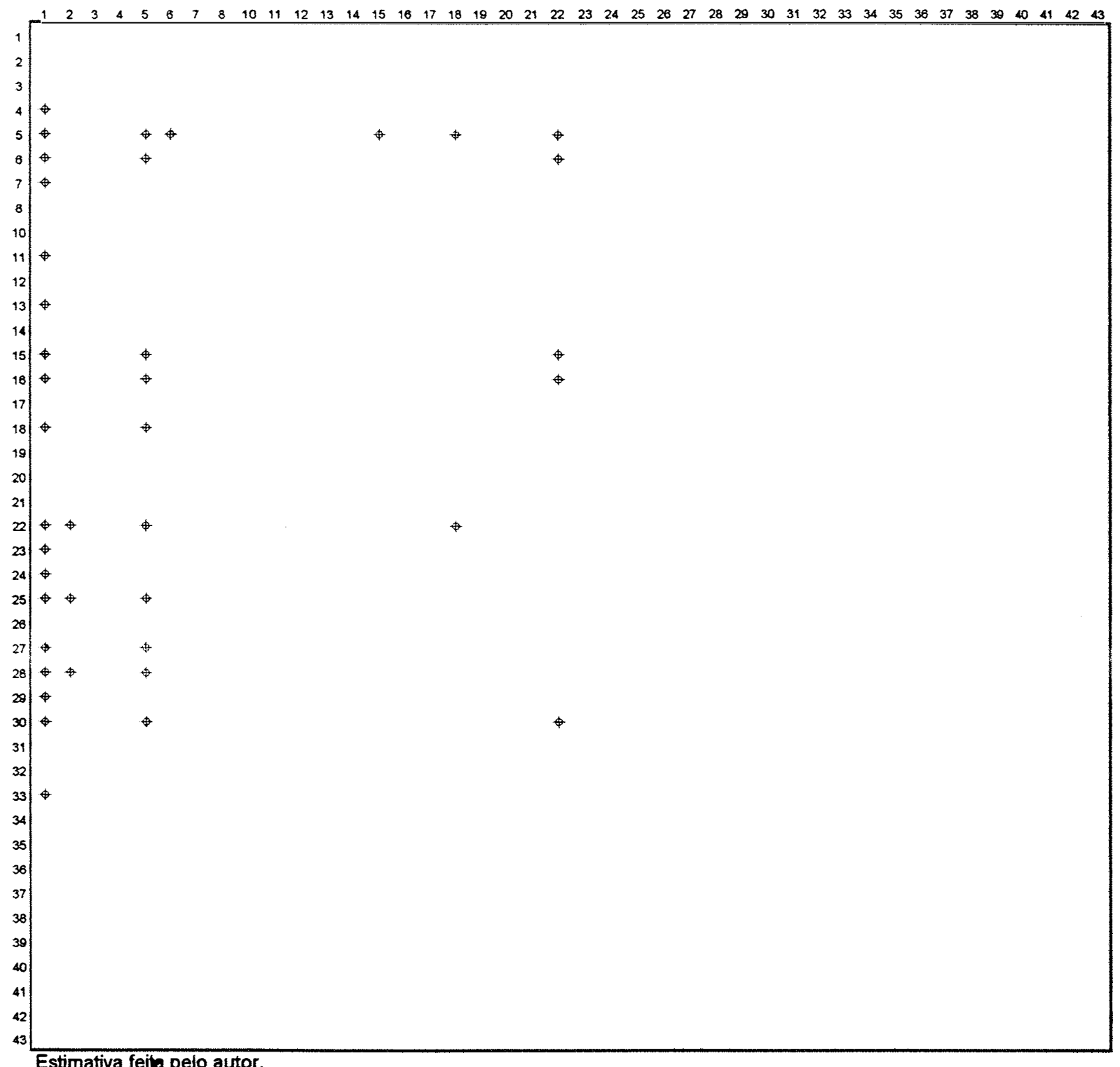

Estimativa feita pelo autor.

Figura 19. Coeficientes com o maior Campo de Influência. BRASIL - 1990. 
estrutura interna da economia não é levada em conta ao se delinearem setores chave, podem surgir gargalos que restrinjam 0 seu crescimento. No entanto, o nível de produção setorial é, também, fator importante uma vez que auxilia na identificação dos principais setores que respondem por alterações nos níveis do PIB e de outras variáveis macroeconômicas. Como resultado temos que os setores chave podem diferir entre os índices de determinação, onde os enfoques de Rasmussen-Hirschman e de Campo de Influência mostram o potencial dos impactos de mudanças em um setor específico, enquanto o índice puro avalia o impacto realizado através da consideração do volume de atividade.

É importante chamar a atenção para o fato de que nas diferentes análises realizadas para os anos de 1980, 1985 e 1990 existe um predomínio dos setores Siderurgia, Metalurgia e Agropecuária em quase todos os enfoques. Alguns setores que compõem os Produtos Alimentares também assumem papel de importância dentro das relações intersetoriais, no que diz respeito ao encadeamento para trás. Por outro lado, a importância de setores como Papel Papelão e Têxtil é captada pelo enfoque de RasmussenHirschman. Ao mesmo tempo, os resultados mostram uma crescente importância do setor Serviços dentro da economia, seguindo a tendência deste segmento dentro de economias mais desenvolvidas.

Em suma, da análise dos dados das matrizes de insumo-produto, pode-se inferir que vem aumentando a complexidade da economia brasileira apresentando um estágio avançado de estrutura produtiva com um alto grau de interligação entre os setores produtivos nacionais. 


\title{
4.2 Composição do Complexo Agroindustrial Brasileiro
}

\begin{abstract}
A partir das estimativas da matriz $A G R(41$ x 42) (Apêndice 2), para os anos 80,85 e 90, pode-se selecionar os grupos de indústrias, a partir da classificação das Matrizes de Insumo-Produto, que comporão os setores formadores do CAI. Essa composição constitui fonte de subsídios importantes para a análise das tendências do CAI ao longo do tempo.
\end{abstract}

As Tabelas 20, 21 e 22 apresentam as interligações da atividade agropecuária com os setores produtivos do pais, em termos de compra de produtos e insumos. Em outras palavras, são analisados os efeitos diretos e indiretos para trás da cadeia produtiva agrícola. Selecionando as atividades que respondem por cêrca de $80 \%$ dos impactos diretos e indiretos ocasionados pela agropecuária, temos as seguintes coincidências nos três períodos considerados: 8 - Eabricação e Manutenção de Máquinas e Tratores; 17 - Fabricação de Elementos Químicos; 18 - Refino do Petróleo; 19 - Fabricação de Produtos Químicos Diversos; 30 Fabricação de óleos Vegetais; 31 - Fabricação de Outros Produtos Alimentares; 35 - Comércio; 36 - Transporte; 40 - Serviços Prestados às Empresas. Note que a ligação para trás da agropecuária com os setores 30 e 31 se explica pelo fato desses ramos abrangerem, respectivamente, tortas, farelos e rações balanceadas (Ver composição dos setores p. 132). Desta forma, esses resultados mostram que a agropecuária tem uma maior interligação para trás com os setores que fornecem "máquinas e tratores", "adubos e fertilizantes", "óleos combustíveis", "tortas e farelos", "rações balanceadas" e "serviços". ${ }^{28}$

28 A relação das classificações das atividades do IBGE com os correspondentes produtos constam do Apêndice 1. 
Tabela 20. Setores ofertantes de insumos para a agropecuária. Valores correntes setoriais (impacto direto e indireto) e participação percentual de cada setor sobre o valor total (impacto total). Brasil: 1980. (Cr\$ milhőes).

\begin{tabular}{|c|c|c|c|c|}
\hline \multicolumn{2}{|r|}{ SETORES } & \multirow[b]{2}{*}{ VALOR } & \multirow[b]{2}{*}{$\%$} & \multirow[b]{2}{*}{ ORDEM } \\
\hline CODIGOIBGE & DESCRIÇAOO & & & \\
\hline$\overline{02}$ & Extrativa Mineral & $6.098,82$ & 0,705 & 24 \\
\hline 03 & Extração de Petróleo e Carvão & $4.081,15$ & 0,472 & 28 \\
\hline 04 & Fabricação de Minerais Não-Metálicos & $5.533,71$ & 0,640 & 25 \\
\hline 05 & Siderurgia & $13.513,22$ & 1,563 & 15 \\
\hline 06 & Metalurgia de Não-Ferrosos & $3.885,33$ & 0,449 & 29 \\
\hline 07 & Fabricação de Outros Produtos Metalúrgicos & $15.045,85$ & 1,740 & 12 \\
\hline 08 & Fabricação e Manutenção de Máquinas e Tratores & $15.145,25$ & 1,752 & 11 \\
\hline 10 & Fabricação de Material Elétrico & $1.648,21$ & 0,191 & 36 \\
\hline 11 & Fabricaçåo de Equipamentos Eletrônicos & 499,49 & 0,058 & 39 \\
\hline 12 & Fabricaça de Automoveis, Caminhões e Onibus & 596,54 & 0,069 & 38 \\
\hline 13 & Fabricação de Peças e Outros Veículos & $4.859,93$ & 0,562 & 26 \\
\hline 14 & Madeira e Mobiliário & $3.633,91$ & 0,420 & 30 \\
\hline 15 & Celulose, Papel e Gráfica & $15.797,34$ & 1,827 & 10 \\
\hline 16 & Indústria da Borracha & $2.952,39$ & 0,341 & 32 \\
\hline 17 & Fabricação Elementos Químicos & $17.074,32$ & 1,975 & 7 \\
\hline 18 & Refino do Petróleo & $96.980,45$ & 11,217 & 3 \\
\hline 19 & Fabricação de Produtos Químicos Diversos & $193.913,84$ & 22,429 & 1 \\
\hline 20 & Indústria Farmacêutica e de Perfumaria & $8.134,87$ & 0,941 & 20 \\
\hline 21 & Indústria de Artigos de Plástico & $9.749,10$ & 1,128 & 18 \\
\hline 22 & Indústria Têxtil & $11.740,94$ & 1.358 & 17 \\
\hline 23 & Fabricação de Artigos do Vestuario & 488,33 & 0,056 & 40 \\
\hline 24 & Fabricação de Calçados & 919,90 & 0,106 & 37 \\
\hline 25 & Indústria do Café & 389,73 & 0,045 & 41 \\
\hline 26 & Beneficiamento de Produtos Vegetais & $13.241,75$ & 1,532 & 16 \\
\hline 27 & Abate de Animais & $3.202,52$ & 0,370 & 31 \\
\hline 28 & Indústria de Laticínios & $1.744,83$ & 0,202 & 35 \\
\hline 29 & Fabricação de Açúcar & $7.261,29$ & 0,840 & 22 \\
\hline 30 & Fabricação de Óleos Vegetais & $16.393,48$ & 1,896 & 9 \\
\hline 31 & Fabricação de Outros Produtos Alimentares & $121.595,63$ & 14,064 & 2 \\
\hline 32 & Indústrias Diversas & $6.900,20$ & 0,798 & 23 \\
\hline 33 & Serviços Industriais de Utilidade Pública & $14.384,90$ & 1,664 & 13 \\
\hline 34 & Construção Civil & $2.470,55$ & 0,286 & 34 \\
\hline 35 & Comércio & $79.226,90$ & 9,164 & 4 \\
\hline 36 & Transporte & $50.600,94$ & 5,853 & 6 \\
\hline 37 & Comunicaçðes & $2.796,99$ & 0,324 & 33 \\
\hline 38 & Instituiçð̃es Financeiras & $16.407,14$ & 1,898 & 8 \\
\hline 39 & Serviços Prestados às Famílias & $14.156,72$ & 1,637 & 14 \\
\hline 40 & Serviços Prestados às Empresas & $60.765,44$ & 7,028 & 5 \\
\hline 41 & Aluguel de Imóveis & $4.241,94$ & 0,491 & 27 \\
\hline 42 & Administração Pública & $8.375,58$ & 0,969 & 19 \\
\hline 43 & Serviços Privados Não Mercantis & $8.120,53$ & 0.939 & 21 \\
\hline & Total & $864.569,95$ & 100,00 & \\
\hline
\end{tabular}

Fonte: Dados básicos doTBGE. 
Tabela 21. Setores ofertantes de insumos para a agropecuária. Valores correntes setoriais (impacto direto e indireto) e participação percentual de cada setor sobre o valor total (impacto total). Brasil: 1985. (Cr\$ bilhões).

\begin{tabular}{|c|c|c|c|c|}
\hline \multicolumn{2}{|r|}{ SETORES } & \multirow[b]{2}{*}{ VALOR } & \multirow[b]{2}{*}{$\%$} & \multirow[b]{2}{*}{ ORDEM } \\
\hline CODIGO IBGE & DESCRIÇAO & & & \\
\hline 02 & Extrativa Mineral & $1.393,95$ & 1,518 & 17 \\
\hline 03 & Extraçāo de Petróleo e Carvão & $2.881,92$ & 3,139 & 6 \\
\hline 04 & Fabricaçāo de Minerais Não-Metálicos & 809,05 & 0,881 & 23 \\
\hline 05 & Siderurgia & $1.438,03$ & 1,566 & 15 \\
\hline 06 & Metalurgia de Não-Ferrosos & 494,64 & 0,539 & 27 \\
\hline 07 & Fabricação de Outros Produtos Metalúrgicos & $1.481,42$ & 1,613 & 14 \\
\hline 08 & Fabricação e Manutenção de Máquinas e Tratores & $1.967,45$ & 2,143 & 10 \\
\hline 10 & Fabricação de Material Elétrico & 216,13 & 0,235 & 33 \\
\hline 11 & Fabricação de Equipamentos Eletrônicos & 96,80 & 0,105 & 36 \\
\hline 12 & Fabricação de Automóveis. Caminnões e Ônibus & 75,51 & 0,082 & 38 \\
\hline 13 & Fabricação de Peças e Outros Veículos & 723,84 & 0,788 & 24 \\
\hline 14 & Madeira e Mobiliário & 343,06 & 0,374 & 31 \\
\hline 15 & Celulose, Papel e Gráfica & $1.580,23$ & 1,721 & 13 \\
\hline 16 & Indústria da Borracha & 455,46 & 0,496 & 28 \\
\hline 17 & Fabricação Elementos Químicos & $2.808,99$ & 3,059 & 7 \\
\hline 18 & Refino do Petróleo & $14.016,41$ & 15,266 & 2 \\
\hline 19 & Fabricaçăo de Produtos Químicos Diversos & $20.974,71$ & 22,844 & 1 \\
\hline 20 & Indústria Farmacêutica e de Perfumaria & $1.000,58$ & 1,090 & 22 \\
\hline 21 & Indústria de Artigos de Plástico & $1.082,68$ & 1,179 & 21 \\
\hline 22 & Indústria Têxtil & $1.274,51$ & 1,388 & 19 \\
\hline 23 & Fabricação de Artigos do Vestuário & 54,84 & 0,060 & 39 \\
\hline 24 & Fabricação de Calçados & 148,67 & 0,162 & 35 \\
\hline 25 & Indústria do Café & 42,02 & 0,046 & 40 \\
\hline 26 & Beneficiamento de Produtos Vegetais & $1.218,40$ & 1,327 & 20 \\
\hline 27 & Abate de Animais & 207,26 & 0,226 & 34 \\
\hline 28 & Indústria de Laticínios & 93,86 & 0,102 & 37 \\
\hline 29 & Fabricaçăo de Açúcar & 514,25 & 0,560 & 26 \\
\hline 30 & Fabricação de Óleos Vegetais & $2.672,13$ & 2,910 & 8 \\
\hline 31 & Fabricação de Outros Produtos Alimentares & $6.559,21$ & 7,144 & 5 \\
\hline 32 & Indústrias Diversas & 602,76 & 0,656 & 25 \\
\hline 33 & Serviços Industriais de Utilidade Pública & $1.953,35$ & 2,127 & 11 \\
\hline 34 & Construção Civil & 254,20 & 0,277 & 32 \\
\hline 35 & Comércio & $7.995,08$ & 8,708 & 3 \\
\hline 36 & Transporte & $6.634,16$ & 7,225 & 4 \\
\hline 37 & Comunicações & 356,25 & 0,388 & 29 \\
\hline 38 & Instituiçðes Financeiras & $1.424,41$ & 1,551 & 16 \\
\hline 39 & Serviços Prestados ds Famílias & $1.585,68$ & 1,727 & 12 \\
\hline 40 & Serviços Prestados às Empresas & $2.663,52$ & 2,901 & 9 \\
\hline 41 & Aluguel de Imóveis & 350,78 & 0,382 & 30 \\
\hline 42 & Administração Pública & $1.370,31$ & 1,492 & 18 \\
\hline \multirow[t]{2}{*}{43} & Serviços Privados Não Mercantis & 0,00 & 0,000 & 41 \\
\hline & Total & $91.816,50$ & 100,00 & \\
\hline
\end{tabular}


Tabela 22. Setores ofertantes de insumos para a agropecuária. Valores correntes setoriais (impacto direto e indireto) e participação percentual de cada setor sobre o valor total (impacto total). Brasil: 1990. (Cr\$ milhōes).

\begin{tabular}{|c|c|c|c|c|}
\hline \multicolumn{2}{|r|}{ SETORES } & \multirow[b]{2}{*}{ VALOR } & \multirow[b]{2}{*}{$\%$} & \multirow[b]{2}{*}{ ORDEM } \\
\hline CODIGO IBGE & DESCRIÇAOO & & & \\
\hline 02 & Extrativa Mineral & $24.427,07$ & 1,260 & 20 \\
\hline 03 & Extração de Petróleo e Carvão & $45.446,77$ & 2,345 & 11 \\
\hline 04 & Fabricação de Minerais Não-Metálicos & $17.084,32$ & 0,881 & 23 \\
\hline 05 & Siderurgia & $31.140,94$ & 1,607 & 16 \\
\hline 06 & Metalurgia de Não-Ferrosos & $10.713,97$ & 0,553 & 26 \\
\hline 07 & Fabricação de Outros Produtos Metalúrgicos & $33.378,49$ & 1,722 & 14 \\
\hline 08 & Fabricação e Manutenção de Máquinas e Tratores & $42.641,10$ & 2,200 & 12 \\
\hline 10 & Fabricação de Material Elétrico & $5.733,41$ & 0,296 & 32 \\
\hline 11 & Fabricação de Equipamentos Eletrônicos & $2.572,70$ & 0,133 & 36 \\
\hline 12 & Fabricą̧āo de Automóveis, Caminhỏes e Ônibus & $2.225,61$ & 0,115 & 37 \\
\hline 13 & Fabricação de Peças e Outros Veículos & $13.167,93$ & 0,679 & 25 \\
\hline 14 & Madeira e Mobiliário & $8.601,99$ & 0,444 & 30 \\
\hline 15 & Celulose, Papel e Gráfica & $36.035,52$ & 1,859 & 13 \\
\hline 16 & Indústria da Borracha & $9.230,18$ & 0,476 & 29 \\
\hline 17 & Fabricação Elementos Químicos & $57.870,35$ & 2,986 & 7 \\
\hline 18 & Refino do Petróleo & $287.465,39$ & 14,831 & 2 \\
\hline 19 & Fabricação de Produtos Químicos Diversos & $417.442,89$ & 21,537 & 1 \\
\hline 20 & Indústria Farmacêutica e de Perfumaria & $20.156,20$ & 1,040 & 22 \\
\hline 21 & Indústria de Artigos de Plástico & $27.281,22$ & 1,408 & 17 \\
\hline 22 & Indústria Têxtil & $26.182,13$ & 1,351 & 18 \\
\hline 23 & Fabricação de Artigos do Vestuário & $1.274,57$ & 0,066 & 39 \\
\hline 24 & Fabricação de Calçados & $3.088,55$ & 0,159 & 35 \\
\hline 25 & Indústria do Café & 680,44 & 0,035 & 40 \\
\hline 26 & Beneficiamento de Produtos Vegetais & $26.007,14$ & 1,342 & 19 \\
\hline 27 & Abate de Animais & $5.282,16$ & 0,273 & 34 \\
\hline 28 & Indústria de Laticínios & $2.193,49$ & 0,113 & 38 \\
\hline 29 & Fabricaçăo de Açúcar & $9.556,17$ & 0,493 & 28 \\
\hline 30 & Fabricação de Óleos Vegetais & $49.812,37$ & 2,570 & 9 \\
\hline 31 & Fabricação de Outros Produtos Alimentares & $153.723,01$ & 7,931 & 4 \\
\hline 32 & Indústrias Diversas & $14.724,96$ & 0,760 & 24 \\
\hline 33 & Serviços Industriais de Utilidade Pública & $59.521,51$ & 3,071 & 6 \\
\hline 34 & Construção Civil & $5.349,88$ & 0,276 & 33 \\
\hline 35 & Comércio & $169.154,55$ & 8,727 & 3 \\
\hline 36 & Transporte & $143.421,56$ & 7,399 & 5 \\
\hline 37 & Comunicaçס̃es & $10.311,12$ & 0,532 & 27 \\
\hline 38 & Instituiçðes Financeiras & $22.133,72$ & 1,142 & 21 \\
\hline 39 & Serviços Prestados às Famílias & $32.418,06$ & 1,673 & 15 \\
\hline 40 & Serviços Prestados às Empresas & $55.924,73$ & 2,885 & 8 \\
\hline 41 & Aluguel de Imóveis & $8.103,32$ & 0,418 & 31 \\
\hline 42 & Administração Pública & $46.792,93$ & 2,414 & 10 \\
\hline \multirow[t]{2}{*}{43} & Serviços Privados Não Mercantis & 0,00 & 0,000 & 41 \\
\hline & Total & $1.938 .272,39$ & 100,00 & \\
\hline
\end{tabular}

Fonte: Dados básicos do IBGE.

Elaborados pela autora 
A Tabela 23 apresenta a estrutura do consumo intermediário do setor agrícola brasileiro nos anos considerados nos fornecendo a participação percentual de cada produto no consumo intermediário total dessa atividade. Os dados referendam os resultados obtidos nas matrizes $A G R$ onde mostram que, do total dos insumos não agrícolas utilizados na produção rural $4 / 5$ correspondem aos itens "adubos", "rações", "óleos combustíveis", "comércio", "transporte" e "mecânica".

Comparando a nível de setores demandantes de produtos agrícolas, observa-se que as coincidências entre os períodos analisados se concentram em 11 setores, os quais juntos representam cêrca de $80 \%$ dos efeitos diretos e indiretos das atividades econômicas sobre a agropecuária. Assim, têm-se os seguintes setores compondo o conjunto da Indústria de Base Agrícola: 14 - Madeira e Mobiliário; 17 Fabricação de Elementos Químicos; 22 - Indústria Têxtiı; 25 - Indústria do Café, 26 - Beneficiamento de Produtos Vegetais; 27 - Abate de Animais; 28 - Indústria de Laticínios; 29 - Fabricação de açúcar; 30 - Fabricação de Óleos Vegetais; 31 - Fabricação de Outros Produtos Alimentares; 39 - Serviços Prestados às Familias (Tabelas 24,25 e 26).

Para uma confirmação desses segmentos pode-se observar o percentual de insumos agropecuários adquiridos pelos diferentes setores agroindustriais sobre o valor total dos insumos utilizados em suas unidades produtivas (Tabela 27). Os mais baixos percentuais de insumos agrícolas são apresentados pelos setores: 15 - Celulose Papel e Gráfica; 16 - Indústria da Borracha e 24 Fabricação de Calçados; que nos anos 80/85/90, em média, utilizam respectivamente $2,28 \%, 4,12 \%$ e $0,25 \%$ de produtos agropecuários ou seus subprodutos não manufaturados em suas unidades produtivas. 
Tabela 23. Estrutura do consumo intermediário da agricultura segundo os diferentes produtos. Brasil: 1980-1985-1990. (Distribuição percentual)

\begin{tabular}{|c|c|c|c|c|c|c|c|}
\hline \multicolumn{2}{|r|}{ SETORES } & \multicolumn{2}{|c|}{1980} & \multicolumn{2}{|c|}{1985} & \multicolumn{2}{|c|}{1990} \\
\hline CODDIGO IBGE & DESCRIÇĀO & $\%$ & ORDEM & $\%$ & ORDEM & $\%$ & ORDEM \\
\hline \multicolumn{8}{|c|}{ - Origem agricola } \\
\hline 0101 & Café em coco & 0,59 & 20 & 6,63 & 5 & 2,49 & 10 \\
\hline 0102 & Cana-de-açúcar & 0,99 & 15 & 1,17 & 17 & 0,86 & 21 \\
\hline 0103 & Arroz em casca & 0,57 & 22 & 0,67 & 24 & 0,42 & 28 \\
\hline 0104 & Trigo em grão & 0,58 & 21 & 3,64 & 10 & 1,35 & 15 \\
\hline 0105 & Soja em grão & 0,76 & 17 & 0,59 & 27 & 0,44 & 27 \\
\hline 0106 & Algodão em caroço & 0,12 & 32 & 0,09 & 33 & 0,06 & 35 \\
\hline 0107 & Milho em grão & 7,48 & 4 & 5,65 & 6 & 5,75 & 5 \\
\hline 0108 & Bovinos e Suínos & 3,18 & 9 & 2,59 & 12 & 2,33 & 11 \\
\hline 0109 & Leite natural & 2,35 & 10 & 3,56 & 11 & 2,83 & 9 \\
\hline 0110 & Aves vivas & 2.10 & 11 & 2,09 & 13 & 1,84 & 13 \\
\hline 0199 & Outros Produtos Agropecuarios & 15.35 & 3 & 9.93 & 2 & 12.90 & 2 \\
\hline Sub-total & & 34,07 & & 36,61 & & 31,27 & \\
\hline 0201 & Mineral ferroso & 0,00 & & 0,00 & & 0,00 & \\
\hline 0202 & Outros minerais & 0,33 & 28 & 1,37 & 16 & 1,13 & 17 \\
\hline 0301 & Petróleo e gás & 0,00 & & 0,00 & & 0,00 & \\
\hline 0302 & Carvão e outros & 0,00 & & 0,00 & & 0,00 & \\
\hline 0401 & Prod. minerais não metálicos & 0,00 & & 0,00 & & 0,00 & \\
\hline 0501 & Prod. siderúrgicos básicos & 0,00 & & 0,00 & & 0,00 & \\
\hline 0502 & Laminados de aço & 0,00 & & 0,00 & & 0,00 & \\
\hline 0601 & Prod. metalúrg. não ferrosos & 0,00 & & 0,00 & & 0,00 & \\
\hline 0701 & Outros produtos metalúrgicos & 0,34 & 27 & 0,41 & 28 & 0,41 & 29 \\
\hline 0801 & Fabric e manut. máq. e equip. & 0.57 & 22 & 0,66 & 25 & 0,57 & 24 \\
\hline 0802 & Tratores e máq. terraplanagem & 0,00 & & 0,00 & & 0,00 & \\
\hline 1001 & Material elétrico & 0,00 & & 0,01 & 37 & 0,01 & 39 \\
\hline 1101 & Equip. eletrônicos & 0,00 & & 0,00 & & 0,00 & \\
\hline 1201 & Autom., Caminhões e ônibus & 0,00 & & 0,00 & & 0,00 & \\
\hline 1301 & Outros veículos e peças & 0,03 & 40 & 0,02 & 36 & 0,02 & 38 \\
\hline 1401 & Madeira e mobiliário & 0,16 & 31 & 0,16 & 30 & 0,17 & 31 \\
\hline 1501 & Papel, celul. papelão e artef. & 0,07 & 36 & 0,13 & 31 & 0,15 & 32 \\
\hline 1601 & Produtos da borracha & 0,00 & & 0,00 & & 0,00 & \\
\hline 1701 & Elem. quím. não petroquimicos & 0,00 & & 0,00 & & 0,00 & \\
\hline 1702 & Alcool de cana e cereais & 0,00 & & 0,00 & & 0,00 & \\
\hline 1801 & Gasolina pura & 0,00 & & 0,00 & & 0,00 & \\
\hline 1802 & Oleos combustiveis e óleo diesel & 3,98 & 8 & 5,64 & 7 & 5,07 & 8 \\
\hline 1803 & Outros prod. do refino & 0,62 & 19 & 0,89 & 20 & 0,94 & 18 \\
\hline 1804 & Prod. petroquímicos básicos & 0,09 & 34 & 0,17 & 29 & 0,18 & 30 \\
\hline 1805 & Resinas & 0,00 & & 0,00 & & 0,00 & \\
\hline 1806 & Gasoalcool & 2,10 & 11 & 0,91 & 19 & 0,87 & 20 \\
\hline 1901 & Adubos & 17,64 & 1 & 15,50 & 1 & 14,16 & 1 \\
\hline 1902 & Tintas & 0,00 & & 0,00 & & 0,00 & \\
\hline 1903 & Outros prod. químicos & 5,11 & 6 & 8,42 & 3 & 7,83 & 4 \\
\hline 2001 & Prod. farm. e de perfumaria & 0,66 & 18 & 0,79 & 21 & 0,81 & 22 \\
\hline 2101 & Artigos de plástico & 0,48 & 24 & 0,59 & 27 & 0,69 & 23 \\
\hline 2201 & Fios têxteis naturais & 0,01 & 41 & 0,01 & 37 & 0,01 & 39 \\
\hline 2202 & Tecidos naturais & 0,00 & & 0,00 & & 0,00 & \\
\hline 2203 & Fios têxteis artificiais & 0,00 & & 0,00 & & 0,00 & \\
\hline 2204 & Tecidos artificiais & 0,00 & & 0,00 & & 0,00 & \\
\hline 2205 & Outros prod. têxteis & 0,55 & 23 & 0,61 & 26 & 0,56 & 25 \\
\hline 2301 & Artigos do vestuário & 0,00 & & 0,00 & & 0,00 & \\
\hline 2401 & Prod. couro e calçados & 0,05 & 38 & 0,09 & 33 & 0,08 & 34 \\
\hline
\end{tabular}


Tabela 23. continuação

\begin{tabular}{|c|c|c|c|c|c|c|c|}
\hline \multicolumn{2}{|r|}{ SETORES } & \multicolumn{2}{|c|}{1980} & \multicolumn{2}{|c|}{1985} & \multicolumn{2}{|c|}{1990} \\
\hline COOIGO IBGE & DESCRICYĀO & $\%$ & ORDEM & $\%$ & ORDEM & $\%$ & ORDEM \\
\hline 2501 & Prochitos do café & 0,01 & 41 & 0,02 & 36 & 0,02 & 38 \\
\hline 2601 & Arroz beneficiado & 0,07 & 36 & 0,11 & 32 & 0,06 & 35 \\
\hline 2602 & Farinha de trigo & 0,00 & & 0,00 & & 0,00 & \\
\hline 2603 & Outros prod. vegetais beneficiados & 0,00 & & 0,00 & & 0,00 & \\
\hline 2701 & Carne bovina & 0,00 & & 0,00 & & 0,00 & \\
\hline 2702 & Came de aves abatidas & 0,00 & & 0,00 & & 0,00 & \\
\hline 2801 & Leite beneficiado & 0,00 & & 0,00 & & 0,00 & \\
\hline 2802 & Outros laticínios & 0,00 & & 0,00 & & 0,00 & \\
\hline 2901 & Açúcar & 0,01 & 41 & 0,01 & 37 & 0,01 & 39 \\
\hline 3001 & Oleos vegetais em bruto & 0,32 & 29 & 1,78 & 14 & 1,46 & 14 \\
\hline 3002 & Oleos vegetais refinados & 0,00 & & 0,00 & & 0,00 & \\
\hline 3101 & Raçzes e outros alimentares & 15,62 & 2 & 7,77 & 4 & 8,53 & 3 \\
\hline 3102 & Bebidas & 0,00 & & 0,00 & & 0,00 & \\
\hline 3201 & Produtos diversos & 0,08 & 35 & 0,09 & 33 & 0,09 & 33 \\
\hline 3301 & Serv. indust. de util. pública & 0,58 & 21 & 0,76 & 22 & 1,22 & 16 \\
\hline 3401 & Prod. da construção civil & 0,01 & 41 & 0,01 & 37 & 0,01 & 39 \\
\hline 3501 & Margem de comércio & 5,51 & 5 & 5,58 & 8 & 5,54 & 6 \\
\hline 3601 & Margem de transporte & 4,36 & 7 & 5,15 & 9 & 5,25 & 7 \\
\hline 3701 & Comunicaçes & 0,03 & 40 & 0,03 & 35 & 0,05 & 36 \\
\hline 3801 & Seguros & 0,10 & 33 & 0,05 & 34 & 0,03 & 37 \\
\hline 3802 & Serviços Financeiros & 1,11 & 14 & 0,72 & 23 & 0,52 & 26 \\
\hline 3901 & Alojamento e alimentação & 0,04 & 39 & 0,02 & 36 & 0,02 & 38 \\
\hline 3902 & Outros serviços & 0,82 & 16 & 1,16 & 18 & 0,90 & 19 \\
\hline 3903 & Saúde e educ. mercantis & 0,00 & & 0,00 & & 0,00 & \\
\hline 4001 & Serv. prest. às empresas & 2,08 & 12 & 1,76 & 15 & 2,12 & 12 \\
\hline 4101 & Aluguel de imóveis & 0,03 & 40 & 0,02 & 36 & 0,03 & 37 \\
\hline 4102 & Aluguel imputado & 0,00 & & 0,00 & & 0,00 & \\
\hline 4201 & Administração pública & 0,00 & & 0,00 & & 0,00 & \\
\hline 4202 & Saúde pública & 0,00 & & 0,00 & & 0,00 & \\
\hline 4203 & Educação pública & 0,00 & & 0,00 & & 0,00 & \\
\hline 4301 & Serv. não mercantis privados & 0,00 & & 0,00 & & 0,00 & \\
\hline Sub-total & & 63,6 & & 61,42 & & 59,52 & \\
\hline Prod. Imp. e Ir & 0 ao 80.000$)$ & 2,33 & & 1,97 & & 9,21 & \\
\hline
\end{tabular}

Fonte: Dados básicos do IBGE.

Elaborados pela autora 
Tabela 24. Setores demandantes de produtos agrícolas. Valores correntes setoriais (impacto direto e indireto) e participação percentual de cada setor sobre o valor total (impacto total). Brasil: 1980. (Cr\$ milhőes).

\begin{tabular}{|c|c|c|c|c|}
\hline \multicolumn{2}{|r|}{ SETORES } & \multirow[b]{2}{*}{ VALOR } & \multirow[b]{2}{*}{$\%$} & \multirow[b]{2}{*}{ ORDEM } \\
\hline CODIGOIBGE & DESCRIÇĀO & & & \\
\hline 02 & Extrativa Mineral & $1.382,96$ & 0,091 & 39 \\
\hline 03 & Extraçåo de Petróleo e Carvão & 518,09 & 0,034 & 41 \\
\hline 04 & Fabricação de Minerais Não-Metálicos & $6.966,47$ & 0,459 & 28 \\
\hline 05 & Sidenurgia & $24.872,29$ & 1,637 & 14 \\
\hline 06 & Metalurgia de Não-Ferrosos & $2.838,08$ & 0,187 & 34 \\
\hline 07 & Fabricaçăo de Outros Produtos Metalúrgicos & $12.860,04$ & 0,846 & 19 \\
\hline 08 & Fabricação e Manutenção de Máquinas e Tratores & $9.344,69$ & 0,615 & 23 \\
\hline 10 & Fabricação de Material Elétrico & $3.552,56$ & 0,234 & 32 \\
\hline 11 & Fabricação de Equipamentos Eletrônicos & $2.283,91$ & 0,150 & 36 \\
\hline 12 & Fabricação de Automóveis, Caminhð̃es e Ônibus & $7.195,16$ & 0,474 & 27 \\
\hline 13 & Fabricação de Peças e Outros Veículos & $7.352,47$ & 0,484 & 26 \\
\hline 14 & Madeira e Mobiliário & $43.791,91$ & 2,883 & 10 \\
\hline 15 & Celulose, Papel e Gráfica & $11.545,07$ & 0,760 & 20 \\
\hline 16 & Indústria da Borracha & $6.806,11$ & 0,448 & 29 \\
\hline 17 & Fabricação Elementos Químicos & $36.581,86$ & 2,408 & 11 \\
\hline 18 & Refino do Petróleo & $7.596,74$ & 0,500 & 25 \\
\hline 19 & Fabricação de Produtos Qúmicos Diversos & $11.131,00$ & 0,733 & 21 \\
\hline 20 & Indústria Farmacêutica e de Perfumaria & $8.917,67$ & 0,587 & 24 \\
\hline 21 & Indústria de Artigos de Plástico & $2.089,20$ & 0,138 & 37 \\
\hline 22 & Indústria Têxtil & $49.857,96$ & 3,282 & 9 \\
\hline 23 & Fabricação de Artigos do Vestuário & $17.235,16$ & 1,134 & 16 \\
\hline 24 & Fabricação de Calçados & $14.259,85$ & 0,939 & 18 \\
\hline 25 & Indústria do Café & $104.944,13$ & 6,908 & 6 \\
\hline 26 & Beneficiamento de Produtos Vegetais & $179.012,57$ & 11,783 & 2 \\
\hline 27 & Abate de Animais & $294.510,47$ & 19,386 & 1 \\
\hline 28 & Indústria de Laticínios & $100.495,55$ & 6,615 & 7 \\
\hline 29 & Fabricação de Açúcar & $72.263,75$ & 4,757 & 8 \\
\hline 30 & Fabricação de Óleos Vegetais & $123.255,28$ & 8,113 & 3 \\
\hline 31 & Fabricação de Outros Produtos Alimentares & $113.280,14$ & 7,457 & 5 \\
\hline 32 & Indústrias Diversas & $4.572,66$ & 0,301 & 30 \\
\hline 33 & Serviços Industriais de Utilidade Pública & $1.697,70$ & 0,112 & 38 \\
\hline 34 & Construção Civil & $33.906,74$ & 2,232 & 12 \\
\hline 35 & Comércio & $18.139,80$ & 1,194 & 15 \\
\hline 36 & Transporte & $9.411,47$ & 0,619 & 22 \\
\hline 37 & Comunicaçðes & 662,04 & 0,044 & 40 \\
\hline 38 & Instituiçð̋es Financeiras & $4.325,40$ & 0,285 & 31 \\
\hline 39 & Serviços Prestados às Famílias & $114.243,20$ & 7,520 & 4 \\
\hline 40 & Serviços Prestados às Empresas & $17.022,04$ & 1,120 & 17 \\
\hline 41 & Aluguel de Imóveis & $2.463,45$ & 0,162 & 35 \\
\hline 42 & Administração Pública & $33.031,06$ & 2,174 & 13 \\
\hline \multirow[t]{2}{*}{43} & Serviços Privados Não Mercantis & $2.988,53$ & 0,197 & 33 \\
\hline & Total & $1.519 .205,23$ & 100,00 & \\
\hline
\end{tabular}


Tabela 25. Setores demandantes de produtos agricolas. Valores correntes setoriais (impacto direto e indireto) e participação percentual de cada setor sobre o valor total (impacto total). Brasil: 1985. (Cr\$ bilhōes).

\begin{tabular}{|c|c|c|c|c|}
\hline \multicolumn{2}{|r|}{ SETORES } & \multirow[b]{2}{*}{ VALOR } & \multirow[b]{2}{*}{$\%$} & \multirow[b]{2}{*}{ ORDEM } \\
\hline CODIGO IBGE & DESCRIÇÁO & & & \\
\hline 02 & Extrativa Mineral & 212,89 & 0,124 & 38 \\
\hline 03 & Extração de Petróleo e Carvão & 168,44 & 0,098 & 39 \\
\hline 04 & Fabricação de Minetais Não-Metálicos & 705,23 & 0,411 & 26 \\
\hline 05 & Siderurgia & $2.808,35$ & 1,639 & 14 \\
\hline 06 & Metalurgia de Não-Ferrosos & 557,72 & 0,325 & 30 \\
\hline 07 & Fabricação de Outros Produtos Metalúrgicos & $1.278,10$ & 0,746 & 22 \\
\hline 08 & Fabricação e Manutenção de Máquinas e Tratores & 974,20 & 0,568 & 24 \\
\hline 10 & Fabricação de Material Elétrico & 465,72 & 0,272 & 31 \\
\hline 11 & Fabricação de Equipamentos Eletrônicos & 264,63 & 0,154 & 36 \\
\hline 12 & Fabricação de Automóveis, Caminhð̃es e Ônibus & 705,09 & 0,411 & 27 \\
\hline 13 & Fabricação de Peças e Outros Veículos & 778,11 & 0,454 & 25 \\
\hline 14 & Madeira e Mobiliário & $3.836,86$ & 2,239 & 12 \\
\hline 15 & Celulose, Papel e Gráfica & $1.567,44$ & 0,915 & 20 \\
\hline 16 & Indústria da Borracha & 681,58 & 0,398 & 29 \\
\hline 17 & Fabricação Elementos Químicos & $11.092,10$ & 6,472 & 6 \\
\hline 18 & Refino do Petróleo & $1.588,15$ & 0,927 & 19 \\
\hline 19 & Fabricação de Produtos Quimicos Diversos & $1.926,04$ & 1,124 & 16 \\
\hline 20 & Indústria Farmacêutica e de Perfumaria & $1.506,65$ & 0,879 & 21 \\
\hline 21 & Indústria de Artigos de Plástico & 271,09 & 0,158 & 35 \\
\hline 22 & Indústria Têxtil & $4.503,29$ & 2,628 & 11 \\
\hline 23 & Fabricaçāo de Artigos do Vestuário & $1.821,75$ & 1,063 & 17 \\
\hline 24 & Fabricação de Calçados & $1.782,53$ & 1,040 & 18 \\
\hline 25 & Indústria do Café & $17.493,97$ & 10,208 & 3 \\
\hline 26 & Beneficiamento de Produtos Vegetais & $22.903,14$ & 13,364 & 2 \\
\hline 27 & Abate de Animais & $25.472,16$ & 14,863 & 1 \\
\hline 28 & Indústria de Laticínios & $8.449,83$ & 4,930 & 8 \\
\hline 29 & Fabricação de Açúcar & $7.068,58$ & 4,124 & 9 \\
\hline 30 & Fabricação de Óleos Vegetais & $13.531,32$ & 7,895 & 4 \\
\hline 31 & Fabricação de Outros Produtos Alimentares & $12.484,52$ & 7,285 & 5 \\
\hline 32 & Indústrias Diversas & 332,31 & 0,194 & 34 \\
\hline 33 & Serviços Industriais de Utilidade Pública & 237,15 & 0,138 & 37 \\
\hline 34 & Construção Civil & $2.716,19$ & 1,585 & 15 \\
\hline 35 & Comércio & $2.933,22$ & 1,712 & 13 \\
\hline 36 & Transporte & $1.144,79$ & 0,668 & 23 \\
\hline 37 & Comunicaçðes & 87,40 & 0,051 & 41 \\
\hline 38 & Instituições Financeiras & 701,71 & 0,409 & 28 \\
\hline 39 & Serviços Prestados às Familias & $10.106,28$ & 5,897 & 7 \\
\hline 40 & Serviços Prestados às Empresas & 354,99 & 0,207 & 32 \\
\hline 41 & Aluguel de Imóveis & 126,29 & 0,074 & 40 \\
\hline 42 & Administração Pública & $5.404,44$ & 3,153 & 10 \\
\hline \multirow[t]{2}{*}{43} & Serviços Privados Não Mercantis & 337,64 & 0,197 & 33 \\
\hline & Total & $171.381,89$ & 100,00 & \\
\hline
\end{tabular}


Tabela 26. Setores demandantes de produtos agrícolas. Valores correntes setoriais (impacto direto e indireto) e participação percentual de cada setor sobre o valor total (impacto total). Brasil: 1990. (Cr\$ milhões).

\begin{tabular}{|c|c|c|c|c|}
\hline \multicolumn{2}{|r|}{ SETORES } & \multirow[b]{2}{*}{ VALOR } & \multirow[b]{2}{*}{$\%$} & \multirow[b]{2}{*}{ ORDEM } \\
\hline CODIGO IBGE & DESCRIÇAO & & & \\
\hline 02 & Extrativa Mineral & $4.799,92$ & 0,149 & 38 \\
\hline 03 & Extração de Petróleo e Carvão & $4.188,46$ & 0,130 & 39 \\
\hline 04 & Fabricação de Minerais Não-Metálicos & $15.725,60$ & 0,489 & 28 \\
\hline 05 & Sidenurgia & $66.928,85$ & 2,080 & 13 \\
\hline 06 & Metalurgia de Não-Ferrosos & $10.212,29$ & 0,317 & 31 \\
\hline 07 & Fabricação de Outros Produtos Metalúrgicos & $31.627,26$ & 0,983 & 19 \\
\hline 08 & Fabricação e Manutenção de Máquinas e Tratores & $21.465,95$ & 0,667 & 24 \\
\hline 10 & Fabricação de Material Elétrico & $11.056,53$ & 0,344 & 30 \\
\hline 11 & Fabricação de Equipamentos Eletrônicos & $7.404,00$ & 0,230 & 35 \\
\hline 12 & Fabricação de Automóveis, Caminhð̃es e Ônibus & $15.965,19$ & 0,496 & 27 \\
\hline 13 & Fabricação de Peças e Outros Veículos & $17.213,55$ & 0,535 & 25 \\
\hline 14 & Madeira e Mobiliário & $103.235,89$ & 3,209 & 10 \\
\hline 15 & Celulose, Papel e Gráfica & $38.873,26$ & 1,208 & 16 \\
\hline 16 & Indústria da Borracha & $17.006,77$ & 0,529 & 26 \\
\hline 17 & Fabricação Elementos Químicos & $179.528,57$ & 5,580 & 7 \\
\hline 18 & Refino do Petróleo & $28.465,67$ & 0,885 & 21 \\
\hline 19 & Fabricação de Produtos Químicos Diversos & $37.325,84$ & 1,160 & 17 \\
\hline 20 & Indústria Farmacêutica e de Perfumaria & $27.518,22$ & 0,855 & 22 \\
\hline 21 & Indústria de Artigos de Plástico & $5.656,84$ & 0,176 & 37 \\
\hline 22 & Indústria Têxtil & $69.761,15$ & 2,168 & 12 \\
\hline 23 & Fabricação de Artigos do Vestuário & $30.601,19$ & 0,951 & 20 \\
\hline 24 & Fabricação de Calçados & $36.938,85$ & 1,148 & 18 \\
\hline 25 & Indústria do Café & $112.891,17$ & 3,509 & 9 \\
\hline 26 & Beneficiamento de Produtos Vegetais & $422.225,75$ & 13,124 & 2 \\
\hline 27 & Abate de Animais & $585.563,70$ & 18,201 & 1 \\
\hline 28 & Indústria de Laticínios & $199.038,36$ & 6,187 & 6 \\
\hline 29 & Fabricação de Açúcar & $96.145,30$ & 2,988 & 11 \\
\hline 30 & Fabricação de Óleos Vegetais & $201.242,36$ & 6,255 & 5 \\
\hline 31 & Fabricação de Outros Produtos Alimentares & $267.157,50$ & 8,304 & 3 \\
\hline 32 & Indústrias Diversas & $7.680,22$ & 0,239 & 33 \\
\hline 33 & Serviços Industriais de Utilidade Pública & $7.420,59$ & 0,231 & 34 \\
\hline 34 & Construção Civil & $61.071,51$ & 1,898 & 15 \\
\hline 35 & Comércio & $61.543,88$ & 1,913 & 14 \\
\hline 36 & Transporte & $21.523,54$ & 0,669 & 23 \\
\hline 37 & Comunicaçð̃es & $1.924,07$ & 0,060 & 41 \\
\hline 38 & Instituiçð̃es Financeiras & $12.409,91$ & 0,386 & 29 \\
\hline 39 & Serviços Prestados às Famílias & $221.742,03$ & 6,892 & 4 \\
\hline 40 & Serviços Prestados às Empresas & $8.841,98$ & 0,275 & 32 \\
\hline 41 & Aluguel de Imóveis & $2.507,00$ & 0,078 & 40 \\
\hline 42 & Administração Pública & $138.406,30$ & 4,302 & 8 \\
\hline \multirow[t]{2}{*}{43} & Servicos Privados Não Mercantis & $6.359,50$ & 0,198 & 36 \\
\hline & Total & $3.217 .194,52$ & 100,00 & \\
\hline
\end{tabular}

Fonte: Dados básicos do IBGE.

Elaborados pela autora 


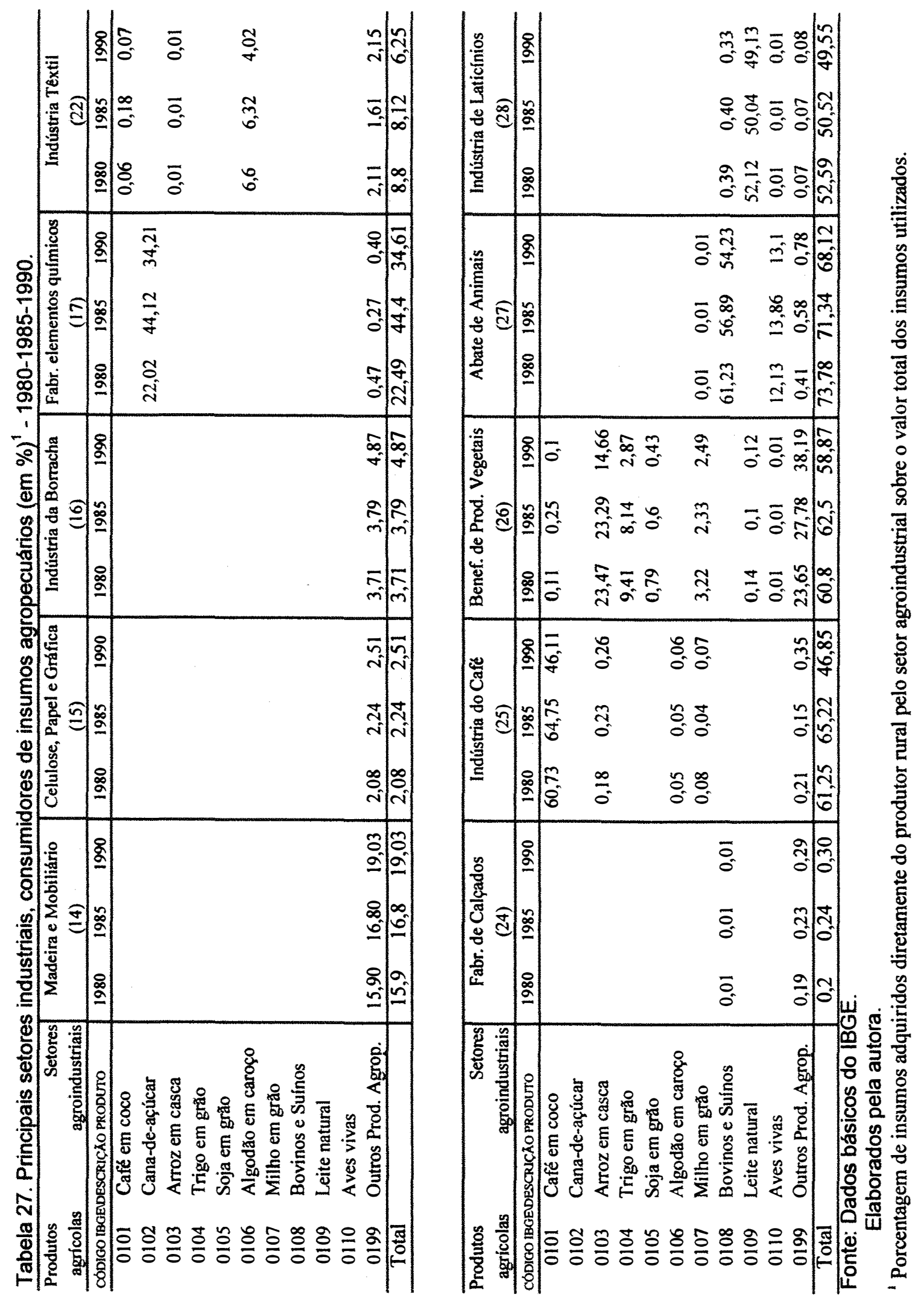




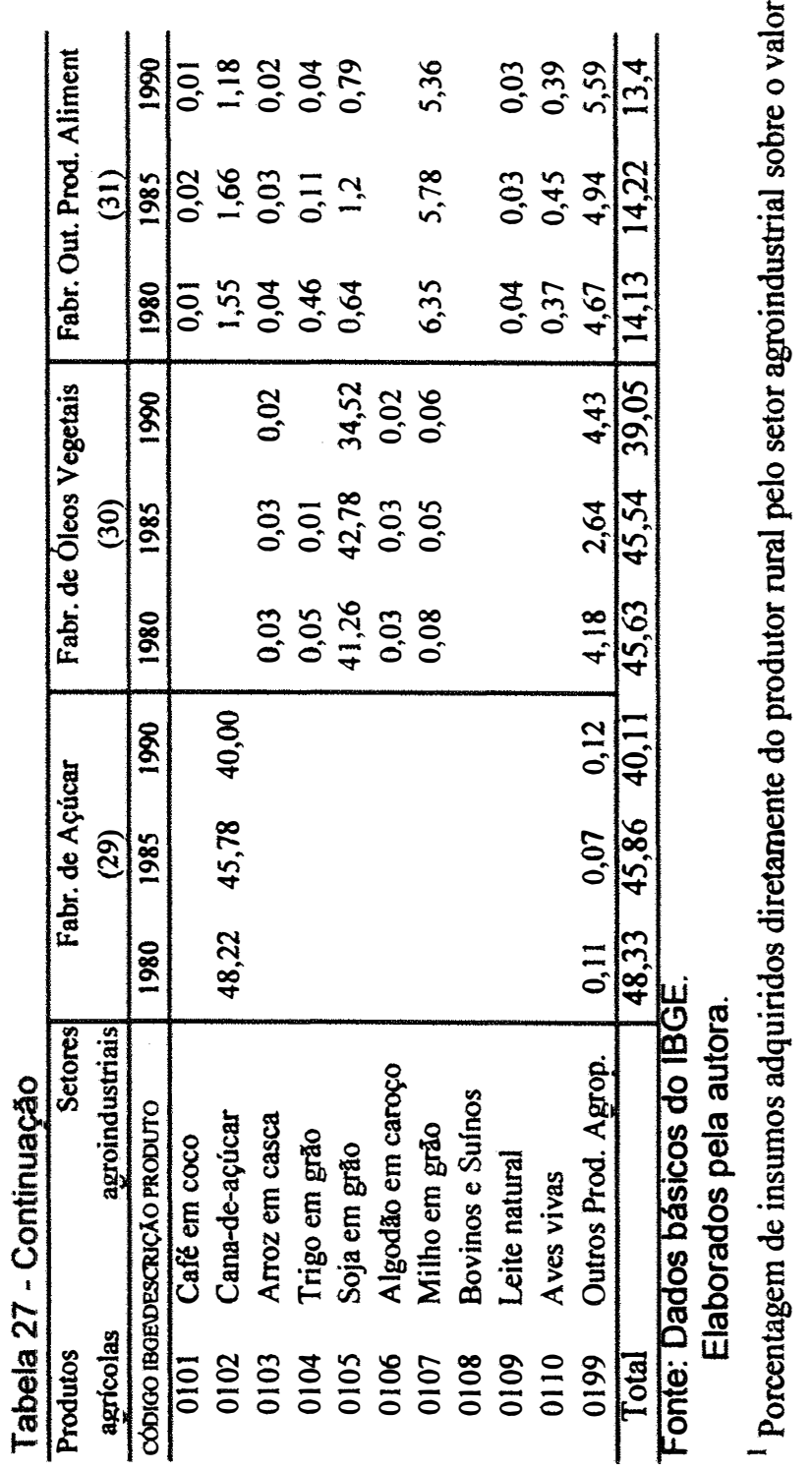


Considerando as análises feitas e os grupos de indústrias para os quais temos dados disponiveis nas Matrizes, propomos a seguinte "composição" para o Complexo Agroindustrial:

O Agregado "Indústria para a agrizultura"
compreenderá 0 grupo das principais indústrias abastecedoras de insumos e bens de capital da agricultura. O termo "Indústria de base agrícola", então, representará o conjunto das indústrias transformadoras e processadoras de matéria-prima de origem agropecuária (um sub-setor do CAI), enquanto a expressão Complexo Agroindustrial será usada para designar o conjunto: Indústria para a agricultura, a Agricultura propriamente dita, Indústria de base agricola, e o setor de Distribuição.

\section{INDÚSTRIA PARA A AGRICULTURA (indústrias a montante):}

\section{Mecânica}

- Fabricação e manutenção de - Fabricação e manutenção de máquimáquinas e tratores (08) nas e equipamentos (0801)

- máquinas industriais

- máquinas não-industriais

- peças para máquinas

- manutenção de máquinas

- Tratores e máquinas de terraplanagem (0802)

\section{Qúmica}

- Fabricação de elementos • químicos (17)

Elementos quimicos não-petroquímicos (1701)

- Álcool de cana e de cereais (1702)

- Refino do petróleo (18)

- Gasolina pura (1801)

- Óleos combustiveis e óleo diesel (1802)

- Outros produtos do refino (1803)

- Produtos petroquímicos básicos (1804) 
- Resinas (1805)

- Gasoálcool (1806)

- Fabricação de produtos qui- - Adubos (1901) micos diversos (19) - Tintas (1902)

- Outros produtos químicos (1903)

Tortas e Farelos

- Fabricação de óleos vege- - Óleos vegetais em bruto (3001) tais (30)

- óleos vegetais em bruto

- tortas e farelos

- Óleos vegetais refinados (3002)

\section{Rações Balanceadas e Alimentos Preparados para animais}

- Fabricação de outros pro- - Rações e outros produtos alimendutos alimentares (31) tares (3101)

- Bebidas (3102)

\section{AGRORECUÁRIA}

- Produtos agrícolas (01)

- Café em coco (0101)

- Cana-de-açúcar (0102)

- Arroz em casca (0103)

- Trigo em grão (0104)

- soja em grão (0105)

- Algodão em caroço (0106)

- Milho em grão (0107)

- Bovinos e suinos (0108)

- Leite natural (0109)

- Aves vivas (0110)

- Outros produtos agropecuários (0199)

- madeira

- carvão e lenha

- extrativa vegetal

- fumo

- reflorestamento

- outros agrícolas

- produtos animais

3. INDÚSTRIA DE BASE AGRÍCOLA (indústrias processadoras) indústrias a jusante)

- Madeira e Mobiliário (14) - Madeira e mobiliário (1401) 
- produtos da madeira

- mobiliário

\section{Química}

- Fabricação químicos (17) de elementos • Elementos químicos não-petroquímicos (1701)

- Álcool de cana e de cereais (1702)

\section{Têxtil}

- Indústria têxtil (22)

- Fios têxteis naturais (2201)

- Tecidos naturais (2202)

- Fios têxteis artificiais (2203)

- Tecidos artificiais (2204)

- Outros produtos têxteis (2205)

\section{Produtos Alimentares}

- Indústria do Café (25) vegetais (26)

- Abate de animais (27)

- Indústria de laticinios (28)

- Fabricação de açúcar (29)

- Fabricação de óleos vegetais (30)
- Beneficiamento de produtos

- Produtos do Café (2501)

- Arroz beneficiado (2601)

- Farinha de trigo (2602)

- Outros produtos beneficiados (2603)

- sucos e conservas

- vegetais beneficiados

- produtos do fumo

- Carne bovina (2701)

- carnes

- outros do abate

- Carne de aves abatidas (2702)

- Leite beneficiado (2801)

- Outros laticinios (2802)

- Açúcar (2901)

- Óleos vegetais em bruto (3001) - oleos vegetais em bruto

- tortas e farelos

- Óleos vegetais refinados (3002)

- Fabricação de outros pro- - Raçoes e outros produtos alimendutos alimentares (31) tares (3101)

- Bebidas (3102)

\section{DISTRIBUIÇÃO FINAI E SERVIÇOS}

- Comércio (35)

- Transporte (36)
- Margem de comércio (3501)

- Margem de transporte (3601) 


$$
\begin{aligned}
& \text { - transporte rodoviário } \\
& \text { - transporte ferroviário } \\
& \text { - transporte hidroviário } \\
& \text { - transporte aéreo }
\end{aligned}
$$

- Serviços prestados as familias (39)

- Serviços prestados às empresas (40)
- Alojamento e alimentação (3901)

- Outros serviços (3902)

- Saúde e educação mercantis (3903)

- Serviços prestados as empresas $(4001)$

No que se refere a indústria para a agricultura podemos observar alguns problemas. O primeiro refere-se ao segmento de mecânica, que engloba equipamentos agrícolas e industriais, não sendo possível isolá-los. O segundo diz respeito ao ramo Química, em que não é possível separar os itens como tintas, resinas e que não estão presentes na estrutura de consumo intermediário agrícola. Outro problema refere-se ao setor de fabricação de outros produtos alimentares por incluir tanto 0 item rações balanceadas como bebidas. A mesma dificuldade operacional ocorre em relação ao setor de fabricação de óleos vegetais que produz itens importantes tanto para o segmento a montante (tortas e farelos) como a jusante (óleos vegetais refinados).

o agrupamento Indústria de base agrícola representa, na maioria, as que efetuam a primeira e segunda transformação das matérias-primas agrícolas.

No âmbito da quantificação do Complexo Agroindustrial adotam-se três versões de agroindústria (para melhor detalhamento ver seção 3.4.3), o que refletirá também em três composições para o CAI. A primeira alternativa analisada (versão 1) engloba as atividades correspondentes aos setores: 17 - Eabricação de elementos químicos; 25 - Indústria do café; 26 - Beneficiamento de 
produtos vegetais; 27 - Abate de animais; 28 -Indústria de laticinios; 29 -Eabricação de açúcar; 30 -Eabricação de óleos vegetais. A segunda alternativa (versão 2) adiciona à versão 1 os segmentos 14 - Madeira e Mobiliário e 31 Eabricação de outros produtos alimentares. A versão 3 inclui à versão 2 o setor 22 -Indústria têxtil.

\subsection{Quantificação do Complexo Agroindustrial Brasileiro}

O novo padrão de produção agrícola, como já mencionado, leva a um crescente estreitamento da relação agricultura/indústria tanto a nível do setor rural como demandante de suprimentos quanto como ofertante de matérias-primas. A quantificação do complexo agroindustrial brasileiro tem como principal objetivo compreender e aprofundar a teoria sobre o mesmo. A hipótese implícita na análise da relação agricultura/indústria é a de que esse processo se dá através de padrões de crescimento diferenciado entre os setores envolvidos e que podem ser detectados pela análise da evolução do produto interno bruto (PIB) agrícola e industrial.

As Tabelas 28 e 29 mostram, em valores correntes e percentuais, a participação do complexo agroindustrial no produto interno bruto brasileiro (medido a custo de fatores). Em 1980, o completo agroindustrial brasileiro já respondia por 33\% do PIB (versão 3) e ainda hoje, após as mudanças estruturais da década de 90 que atingiram diferencialmente os vários setores da economia brasileira, responde por cerca de $32 \%$. É um segmento complexo que 


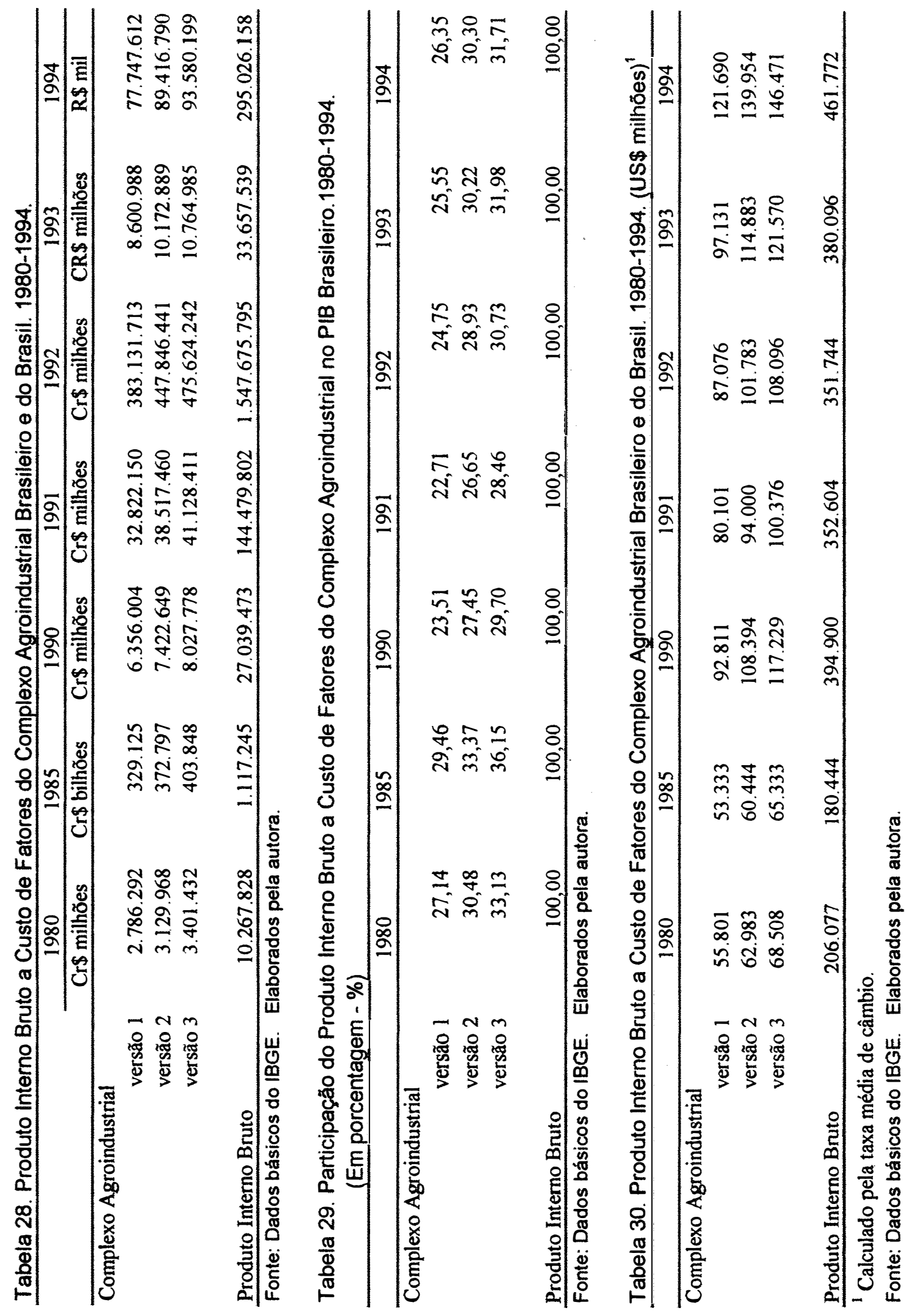


envolve os agentes dos setores primário (agricultura), secundário (indústria) e terciário (serviços). ${ }^{29}$

Ramalho (1988) afirma que os segmentos que compõem - complexo agroindustrial brasileiro respondem por cerca de $40 \%$ do Produto Interno Bruto. No entanto, sua análise toma como referencial as informações provenientes de associações e instituições patronais, sindicatos, industrias além de revistas especializadas em análises econômicas financeiras empresariais.

A análise da produção do complexo agroindustrial norte-americano e de outras economias desenvolvidas permitem compreender não só a conceituação de CAI como detectar algumas tendências históricas da evolução do "agribusiness". Como descreve Lauschner (1993) nesse processo ocorre a participação crescente dos insumos rurais onde esse ramo passa a ser sempre mais representativo no valor da produção vendida pelos agricultores; importância crescente da agroindústria onde $\bigcirc$ setor vai ganhando gradativamente em participação relativa, incrementando sua renda. Nesse processo, a agropecuária perde importância na composição da produção do CAI com diminuição relativa de renda do setor em relação ao do complexo agroindustrial.

O fenômeno citado também vem ocorrendo no Brasil como pode ser observado pelas Tabelas 31 a 39 que mostram a composição do produto interno bruto, a custo de fatores, do complexo agroindustrial brasileiro no período 1980/1994, em valores correntes e seus respectivos valores percentuais, segundo as três versões consideradas para o conceito de complexo agroindustrial (Ver seção 3.4.3).

29 As estimativas realizadas são também expressas em Dólares (U\$) para uma melhor visualização. 
O complexo agroindustrial aqui considerado é composto de quatro segmentos. A parte do CAI, anterior à agropecuária, que expressa o conjunto de setores que produzem insumos adquiridos pelos produtores rurais, denominada Indústria Para a Agricultura ou Montante (Agregado I). O agregado II é a agropecuária propriamente dita. Por sua vez, a parte que responde pelo armazenamento, processamento e distribuição da produção rural no mercado é chamada de Jusante e é formada pelos segmentos denominados de Indústria de Base Agrícola (Agregado III) e de Distribuição Einal (Agregado IV).

Tomando como base a versão 3 (Tabelas 37, 38), 0 complexo agroindustrial brasileiro, em 1980, vendia ao consumidores Cr\$3 3.401.432 milhões, dos quais Cr\$ 348.718 milhões eram as compras de insumos feito pelos produtores rurais ou as vendas da Indústria Para a Agricultura ou Agregado I do $\operatorname{CAI}(10,3 \%$ do total); Cr\$ 1.147 .902 milhões $(33,8 \%$ ) era a renda (ou valor agregado) do setor agropecuário (agregado II) e os que armazenavam, processavam e distribuíam a produção rural recebiam Cr\$ 1.904 .812 milhões $(56,0 \%)$. Dessa forma, do total da produção do CAI, 33,8\% era produzida no campo e 66,3\% na cidade.

Das mesmas Tabelas 37/38, vê-se que o Brasil, em 1990, contava com um CAI que vendia aos consumidores Cr\$ 8.027.778 milhões, dos quais Cr\$ 825.652 milhões lou $10,3 \%)$ correspondiam as compras de insumos do setor rural (agregado I), Cr\$ 2.261.619 milhões $(28,28)$ era o valor adicionado dos agricultores (agregado II) e Cr\$ 4.940.507 milhões $(61,5 \%$ ) como renda da jusante (agregado III e IV). Do valor total da jusante, a renda ou valor adicionado pelo segmento Indústria de Base Agrícola alcançava Cr\$ 1.770.211 

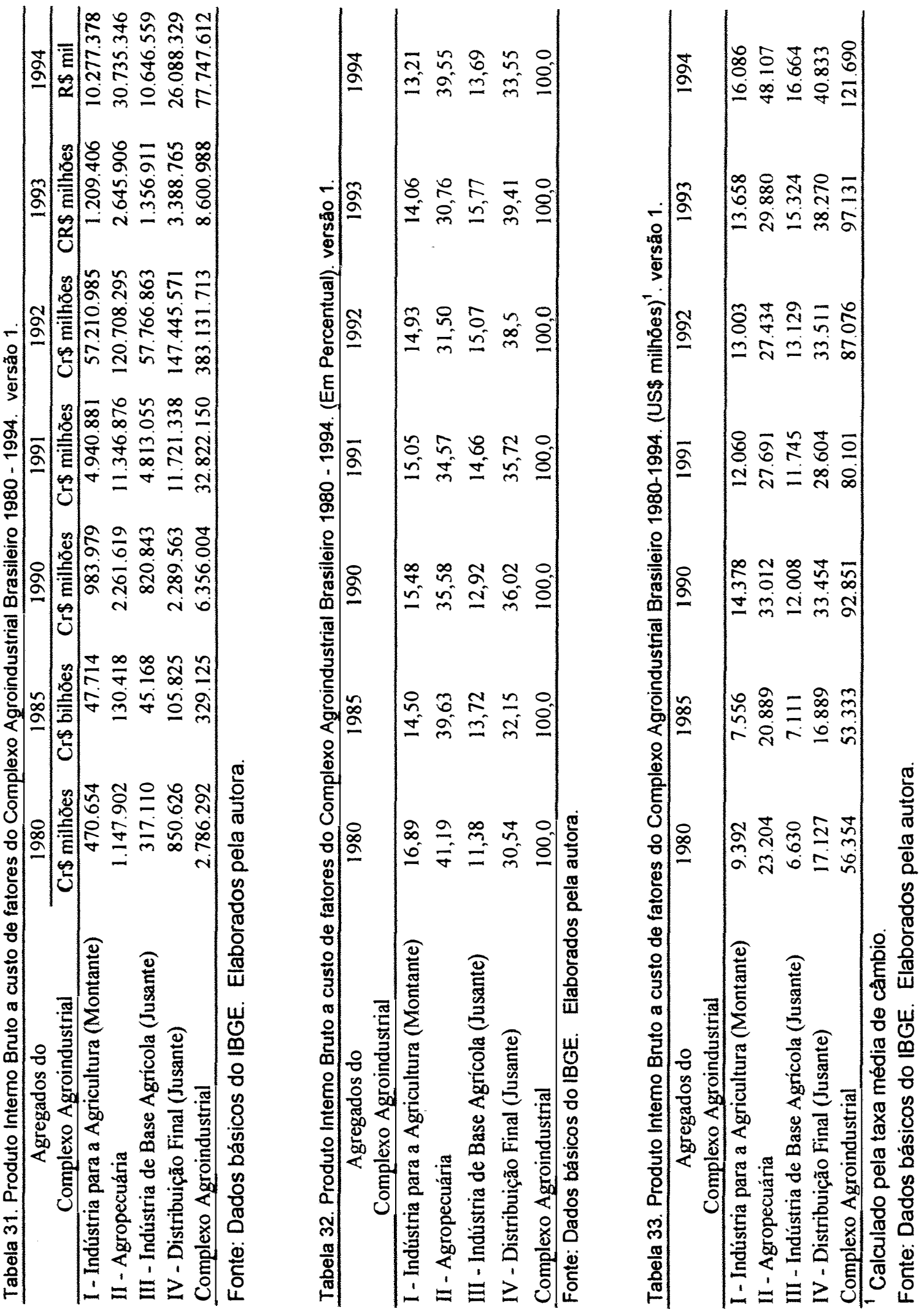


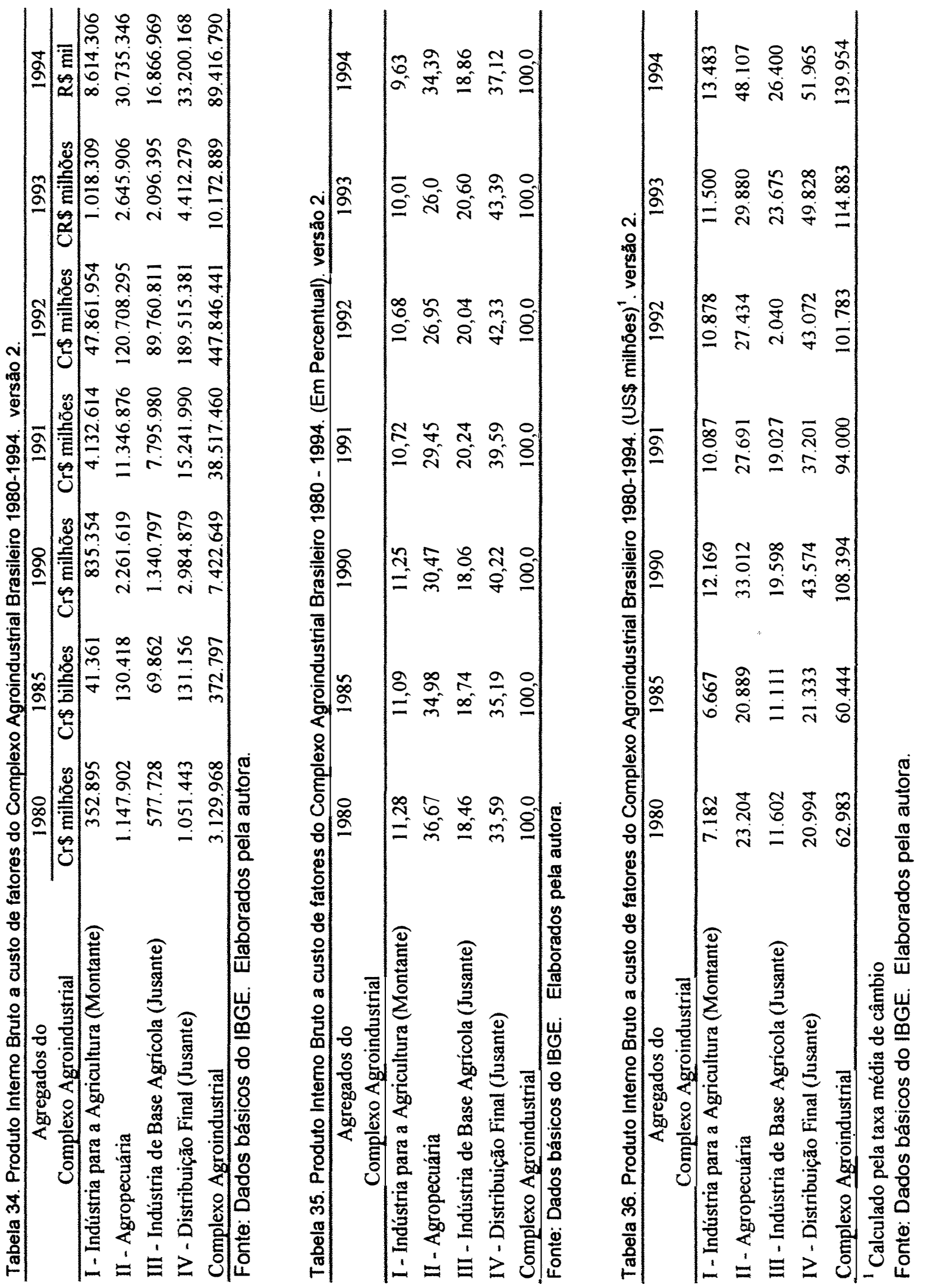




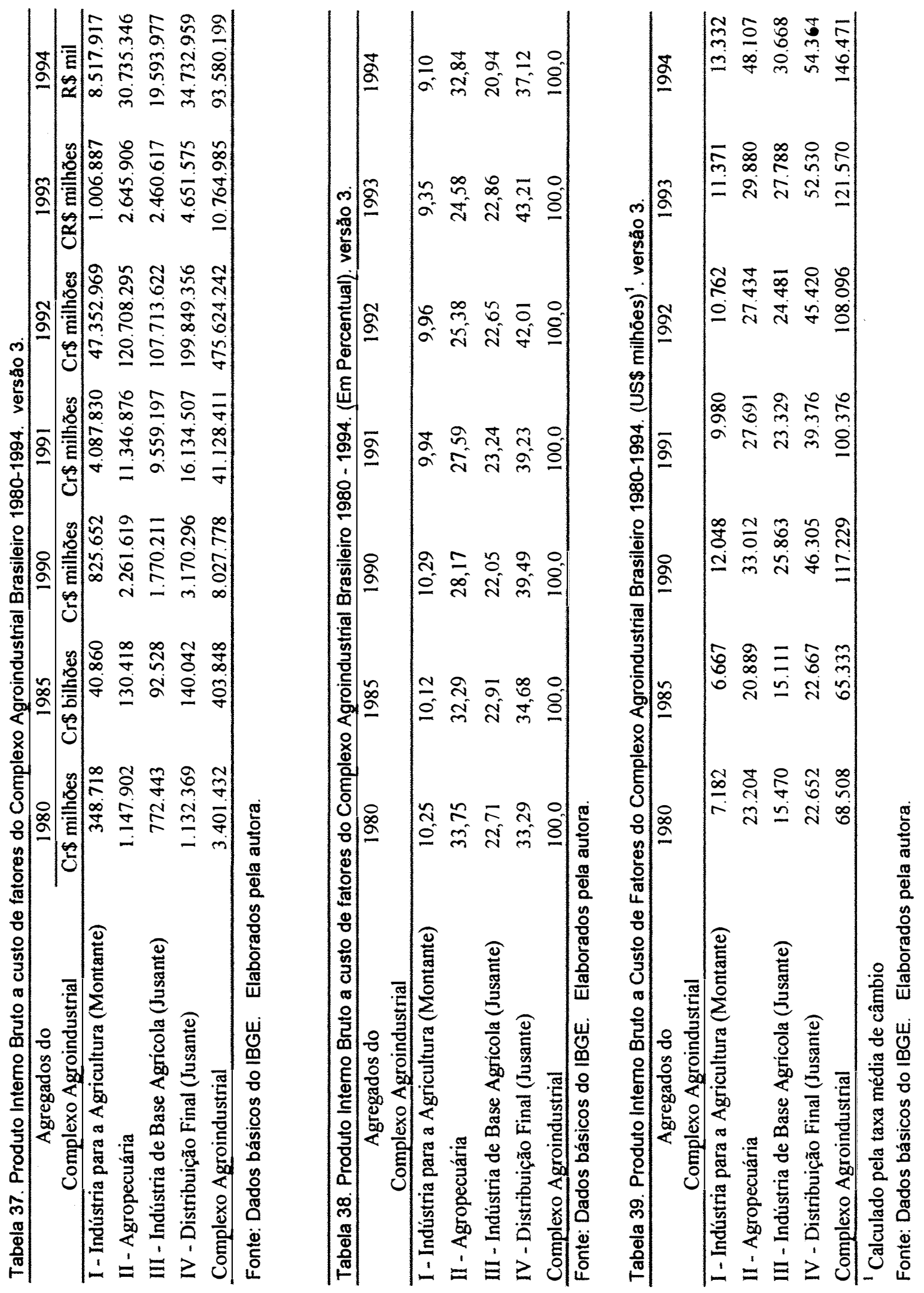


milhões (ou 22,1\% do valor do CAI) e o valor adicionado pelo segmento de Distribuição Final chegava a Cr\$3.170.296 milhões $(39,5 \%)$.

Pela análise dos dados observa-se que no período 1980 a 1993 a participação da agropecuária no PIB do Complexo Agroindustrial - versão 3 (medido a custo de fatores) caiu, passando de 33,8\% para 24,6\% (Tabela 38). Em contrapartida, a participação da jusante, composto pela Indústria de Base Agrícola e Distribuição Einal cresceu passando de 56,0\% para 66,1\%. Fenômeno oposto ao da jusante ocorreu com a Industria Para a Agricultura (Agregado I), que diminuiu gradativamente sua participação no PIB no mesmo período passando de 10,3\% em 1980 para 9,4\% em 1993. As mesmas tendências foram encontradas nas versões I e II do CAI (Tabelas 32 e 35).

A análise de Lauschner (1993) confirma a tendência de comportamento do CAI e complementa essas informações no sentido de que realiza 0 detalhamento das contas do complexo agroindustrial brasileiro referentes a 1970, chamado pelo autor de complexo rural, utilizando a Matriz de Relações Intersetoriais (IBGE) e o enfoque de Malassis. o Brasil, em 1970, contava com uma composição do CAI onde o setor a montante representava $11 \%$ do valor total, a jusante $55 \%$ e a produção rural 34\%. No cálculo do agregado I (setor a montante) $\circ$ autor considera $\circ$ valor total dos bens adquiridos pelo agregado II (produção rural), incluindo também os insumos do próprio setor rural, ou seja, os fatores de produção agropecuários e extrativo-vegetais.

Vê-se, pelos resultados apresentados, que a agricultura brasileira insere-se na atual tendência da economia mundial adaptando-se à situação dos consumidores, concentrados nas regiões urbanas com estrutura de consumo 
sofisticada onde exige sempre maior participação de produtos industrializados e diversificados.

Em suma, o "agribusiness" brasileiro adiciona valor sobre as matérias-primas agrícolas onde 0 setor de armazenamento, processamento e distribuição final tende a ser sempre mais representativo no valor total da produção vendida ao consumidor dominando as relações agricultural indústria. Para visualizar melhor a importância do setor agroindustrial, como grande intermediário entre o produtor rural e 0 consumidor, pode-se mostrar através das informações das matrizes insumo-produto - 80/85/90 que aproximadamente $70 \%$ da produção agropecuária são absorvidos como insumo em outros setores e desse total cerca de $3 / 4$ (72\% média dos anos 80/85/90) são destinados a insumos agroindustriais. O resultado da participação crescente da agroindústria é a maior concentração da renda na jusante, que segundo Goldberg (1990) pode atingir até $80 \%$ do valor do CAI.

Como salienta Lauschner (1993), o agregado I ou Indústria Para a Agricultura no início das transformações a que a agricultura se submete tende a uma participação crescente no valor da produção vendida pelos agricultores ocasionada pelo desenvolvimento tecnológico e da divisão de trabalho. No entanto, a tendência do setor de insumos, depois de totalmente tecnificada a estrutura do CAI, parece ser de declínio gradativo da sua participação relativa o que se justifica pela sempre maior participação da Indústria de Base Agrícola e de Distribuição final.

Em relação à agropecuária observa-se que a renda tende a diminuir sempre mais em relação aos outros agregados do CAI. Essa característica tem sido registrada 
nos países desenvolvidos e em vias de desenvolvimento e uma das causas apontadas por alguns analistas além dos aspectos já comentados, é a estrutura de mercado dos agregados do "agribusiness" onde a agricultura que possui uma estrutura atomizada se vê pressionada por segmentos altamente articulados entre si com estruturas econômicas altamente oligopólicas e monopólicas. Portanto, embora seja indiscutível a função essencial desempenhada pelo produtor rural numa economia, é ao mesmo tempo um desafio constante pois o desenvolvimento da estrutura do "agribusiness" leva a uma participação reduzida do valor gerado pelo mesmo.

A esse respeito vale lembrar o trabalho de Guimarães (1979), referindo-se a um macro-complexo, em que faz uma sinopse histórica da formação do CAI no Brasil, definido pela agricultura e indústrias a jusante e a montante, surgido a partir da internalização do $D_{1} e$ do processo de substituição de importações. Designa o crescente relacionamento da agricultura com o setor industrial de integração técnico-produtiva, onde a tônica é dada pelo setor industrial, por este apresentar maior capacidade de acumulação capitalista. O autor aprofunda-se no tema formulando a noção da "tesoura dos preços" onde a integração intersetorial ocorre com a agricultura se localizando entre dois segmentos de mercado extremamente fortes. Enquanto a indústria para a agricultura consegue impor preços aos insumos adquiridos pelos seus compradores, a agroindústria processadora mantém uma relação oligopsônica com o setor rural, na compra de matéria-prima, tanto no que se refere aos preços como ao tipo e padrão dos produtos. 
Segundo Santana (1994) "o processo de organização da agricultura em cooperativas e outros gêneros de associações correlatas pode afetar favoravelmente as oportunidades de comportamento que envolvem a coordenação e o desenvolvimento do CAI, assim como melhorar sua vantagem competitiva". Enfatiza que este tipo de organização é inclusive tão importante para dinamizar $\circ \mathrm{CAI}$ quanto a influência das estruturas de mercado, da produção, e da informação tecnológica.

Por sua vez, Lauschner (1993) destaca a importância da agroindústria cooperativa como modelo ideal de organização para o pequeno produtor rural. Para isso analisou a experiência prática de uma agroindústria pecuária cooperativa - Cooperativa Central Gaúcha de Leite Ltda. (CCGL) - cujo objetivo principal era apoiar o pequeno produtor rural. Para esse autor, "O estudo da CCGL, quando olhada numa perspectiva de desenvolvimento rural, que pode ser projetado parcialmente a outras regiões e paises, mostra dois aspectos fundamentais: a agroindústria cooperativa, quando bem viabilizada, pode maximizar o apoio aos agricultores; e a integração do produtor na agroindústria cooperativa, mediante contratos de produção e integração, pode significar racionalização empresarial que, longe de explorar, maximiza os beneficios do produtor (não assegurando benefício monopsônico ao capital, como nos outros modelos de empresas agroindustriais" (Lauschner, 1993).

Em suma, há toda uma literatura, na economia agrária, concentrada no esforço de mostrar que a operacionalização do CAI leva a uma exploração do produtor, 
visto que há uma compressão entre preços e custos ("costprice squeeze").

É patente, porém, a importância que assume as organizações e associações para os produtores, por meio dos quais podem superar essas dificuldades operacionais, inserindo-se ativamente no processo de integração econômica entre a agricultura e a indústria e unificando os interesses econômicos dos produtores, da indústria para a agricultura e da indústria de base agrícola, o que sem dúvida, refletirá num real crescimento e fortalecimento do conjunto de todos os setores envolvidos nessa dinâmica.

De fato, à medida que o processo integrativo avança, o papel e o próprio "modus operandi" do setor rural vai se transformando. No entanto, se observarmos a tradicional dicotomia entre agricultura e indústria, constata-se que surgiram oportunidades bastante positivas para o setor agrícola. Vale notar, outrossim, que o PIB da agropecuária passa de U\$23.204 em 1980 para U\$29.880 em 1993 e U\$48.107 em 1994. Portanto, aumenta para uma população de produtores que tende a ser decrescente, o que pode estar levando um acréscimo na renda dos produtores (Tabela 39).

Dessa forma, é importante também frisar que a articulação agricultura/indústria fatalmente levará com que os produtores adotem a racionalidade empresarial nos seus negócios e a inovação tecnológica, o que sem dúvida redundará na modernização do setor e em ganhos para os produtores.

Malassis (1968) define uma economia alimentar como pré-industrial quando o Agregado I participa em torno de 5\% do valor da mesma, o Agregado III e IV (jusante) em torno de $20 \%$ e o produtor rural 75\%. Passa a considerar a 
economia alimentar como industrializada quando o complexo agroindustrial é composto por cerca de $17 \%$ do Agregado I (Montante), $30 \%$ do Agregado II e acima de $50 \%$ do Agregado III e IV (Jusante). A condição básica para essa transformação é a redução da participação da renda dos agricultores em menos de $1 / 3$ na renda global do complexo agroindustrial (citado por Lauschner, 1993). Segundo esse critério de avaliação, o caso brasileiro, no período em análise, indica um Agregado III e IV dinâmico e diversificado (em torno de 60\%), porém um Agregado I relativamente pouco desenvolvido (em torno de 9\%). O Agregado II apresenta variações na sua participação com tendências a redução até 1993 (25\%). Portanto, pela classificação de Malassis a economia agroindustrial brasileira pode ser descrita como uma economia em franco processo de industrialização mostrando seu potencial para galgar o patamar de uma economia industrial.

Araújo et al. (1990), a partir dos dados censitários de 1980, faz estimativas decompostas do Complexo Agroindustrial brasileiro. O procedimento dos autores para a montagem de um quadro da participação do "agribusiness" na composição da Renda Nacional foi o de computar os valores da produção dos agregados componentes do CAI. Apesar dos resultados não serem comparáveis com os da presente pesquisa, pois partem de uma base metodológica e de construção de dados diferentes, observa-se na repartição do valor adicionado do CAI a tendência de menor participação do setor rural no valor total e a maior participação do segmento "após a porteira" da fazenda, mostrando seu comportamento altamente dinâmico nesse ramo de negócios. 
Contudo, cabe assinalar que o ano de 1994 traz uma perspectiva nova para a evolução do CAI. A agropecuária registra um aumento de participação no PIB, passando de 24,58\% em 1993 para 32,84\% em 1994 (Tabela 38). Trata-se de uma recuperação da agropecuária não esperada retornando aos níveis praticados no início dos anos 80. Em contrapartida, - segmento a jusante apresenta redução da participação no PIB, passando de $66,1 \%$ para 58,1\% (versão 3). Enquanto 0 ramo Indústrias de Base Agrícola permanece praticamente estável, o setor de Distribuição apresenta uma tendência de queda na participação do PIB passando de 43,21\% em 1993 para 37,12\% em 1994. Já 0 ramo Indústrias para A Agricultura mantém a sua tendência de queda atingindo 9,1\% do total do PIB (versão 3). Entretanto, a interpretação destes dados exige cautela, pois são resultados aparentemente contraditórios, cabendo lembrar dos riscos metodológicos usuais em levantamentos estatisticos que podem acarretar distorções nos resultados.

Trata-se de uma reação importante da agropecuária às mudanças no contexto nacional. Contudo, os fatores explicativos desse fenômeno devem ainda ser melhor estudados para se compreender as tendências emergentes no "agribusiness" brasileiro.

- Produto Interno Bruto da economia brasileira segundo as grandes classes de atividade econômica mostra a dinâmica dos países capitalistas no processo de desenvolvimento econômico que concentram as atividades nos setores urbano-industriais e gradativamente a agropecuária perde importância relativa na composição do Produto Interno Bruto (PIB), colaborando no processo de crescimento econômico via transferência de capital e de mão-de-obra (Tabelas 40 a 43 ). 
Com efeito, as estimativas do PIB a preços correntes e em percentuais, mostram que no período de 1980 a 1991 a participação da agropecuária no PIB, medido a custo de fatores, caiu, passando de $11,2 \%$ para 7,8\%. No entanto, essa dinâmica sofreu uma interrupção a partir de então, sendo que entre os anos de 1991 a 1993 registra-se uma relativa estabilidade e um avanço na participação relativa da agropecuária no PIB em 1994, passando de 7,9\% em 1993 para 10,4\% em 1994 (Tabelas 40 e 42).

Buscando interpretar essa mudança de padrão de comportamento da agropecuária brasileira no período 91/94 analisar-se-á a evolução de algumas variáveis que podem estar impactando positivamente no desempenho agricola.

A Eigura 20 permite observar a trajetória de evolução da relação preços recebidos/preços pagos para a agropecuária mostrando a evolução do valor adicionado por unidade de produto gerado. Durante 90/94 esse indice teve uma tendência de alta evidenciando claramente um movimento de crescimento do valor adicionado no segmento agrícola. 


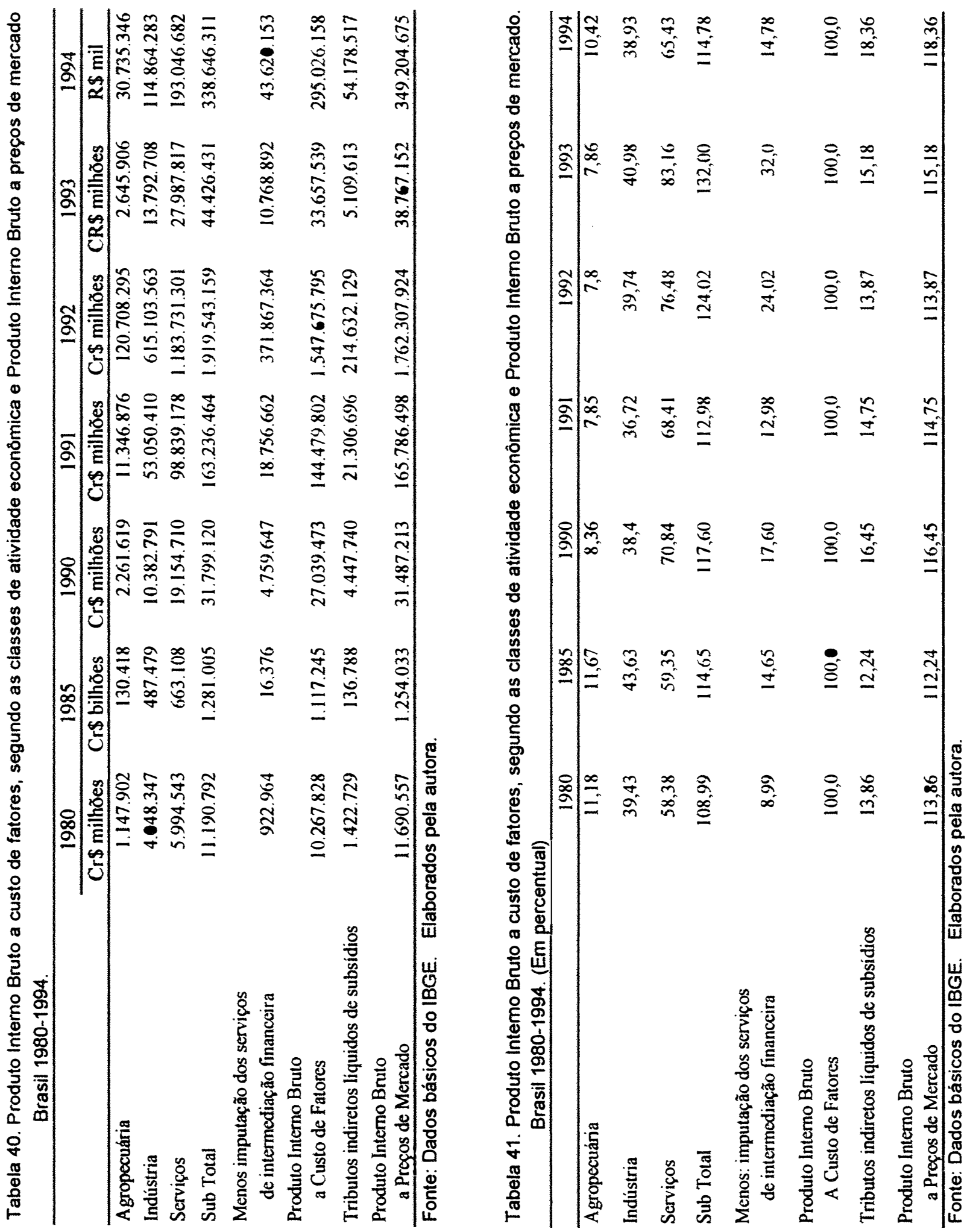




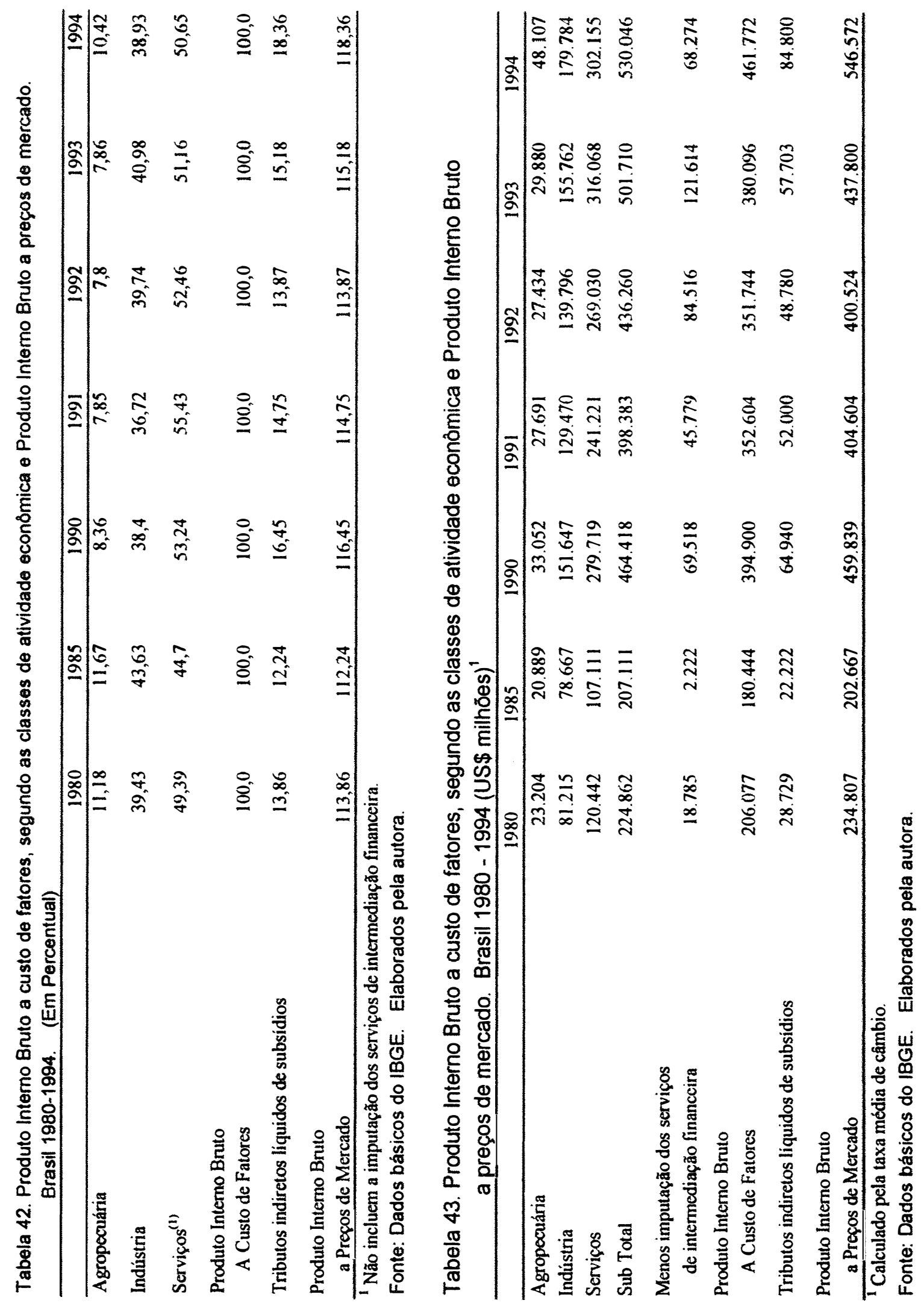


Por outro lado, a Figura 21 referente a evolução da relação entre preços agrícolas e industriais, ambos ao nível de atacado mostra expressiva melhoria nos preços relativos agrícolas/industriais, no período 89/96.

o comportamento desses índices podem ter contribuido, conjuntamente, para uma melhora da participação da agropecuária na composição relativa do PIB total e do complexo agroindustrial brasileiro.

A terceira variável causadora dessa melhora do desempenho agrícola possivelmente foi $\bigcirc$ aumento físico da quantidade produzida na agropecuária, principalmente em 94. A Tabela 44, elaborada por Melo (1997), mostra os dados da evolução das áreas cultivadas, produção e produtividade de um subconjunto de oito produtos agrícolas importantes na economia brasileira. Nota-se que houve um crescimento, embora modesto, na quantidade produzida com expressivo declínio da área cultivada total e significativo crescimento da produtividade da terra, com aumento de 13,1\% no período analisado.

É importante ressaltar que essas três variáveis, associadas entre si, possivelmente provocaram a recuperação de importância da agropecuária na composição do Produto Interno Bruto (PIB) brasileiro. 


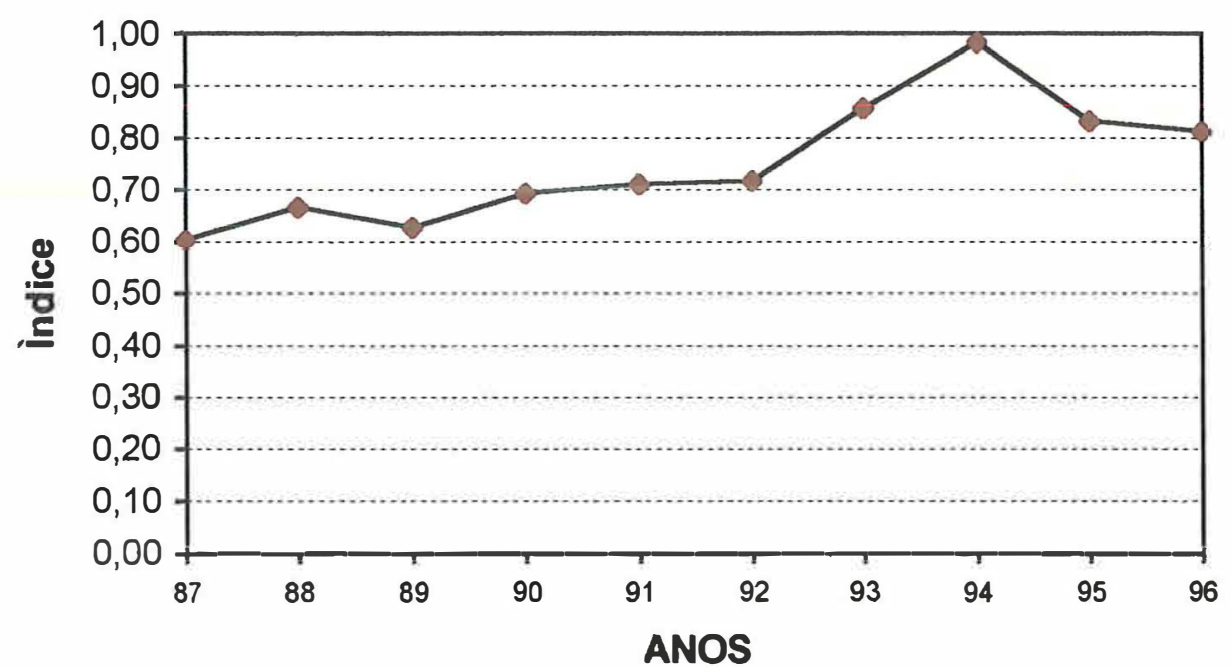

Eonte: Revista Conjuntura Econômica e Agroanalysis. Elaborado pela autora.

Nota: O ano-base do índice é agosto/1994.

Figura 20. Relação de preços recebidos/pagos da agropecuária.

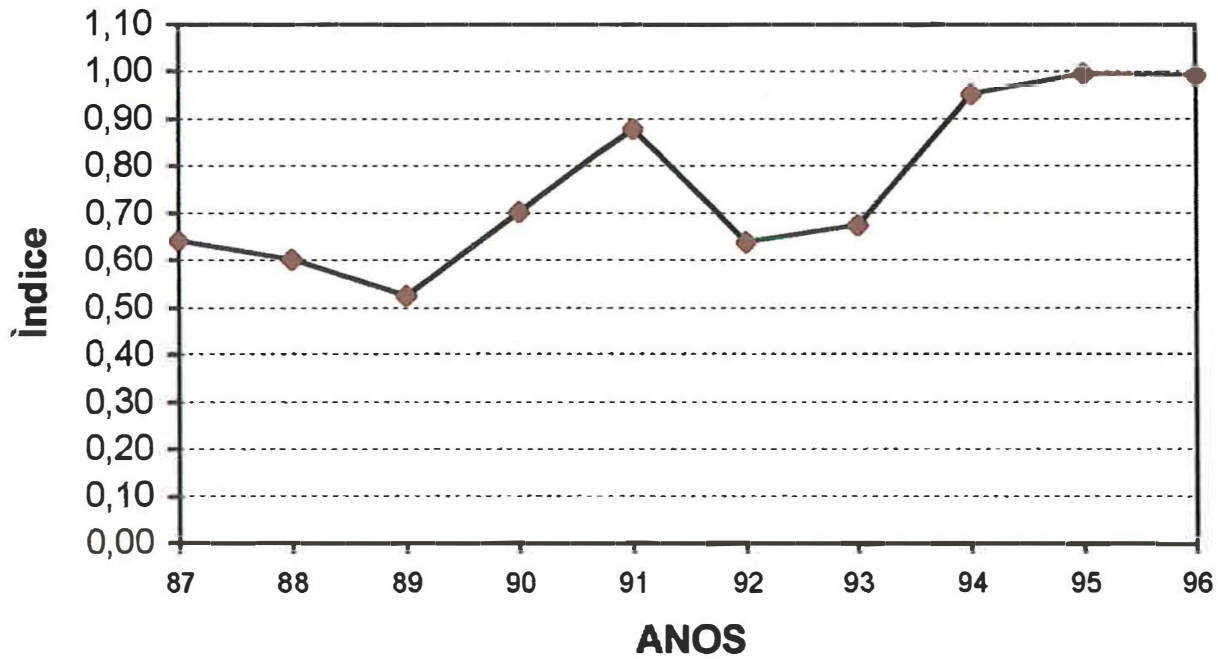

Fonte: Revista Conjuntura Econômica. Elaborado pela autora. Nota: O ano-base do índice é agosto/1994.

Figura 21. Relação de preços no atacado agricultural indústria 
Tabela 44. Evolução dos indices de área cultivada, guantidade produzida e produtividade na agricultura brasileira, 1989/96. $(1989=100)^{a}$

\begin{tabular}{crrc}
\hline ANOS & ÁREA & PRODUÇÃO & PRODUTIVIDADE \\
\hline $\mathbf{1 9 8 9}$ & 100,0 & 100,0 & 100,0 \\
$\mathbf{1 9 9 0}$ & $\mathbf{8 9 , 5}$ & 85,8 & 96,0 \\
$\mathbf{1 9 9 1}$ & 93,3 & 87,0 & 93,2 \\
$\mathbf{1 9 9 2}$ & 94,3 & 95,7 & 101,5 \\
$\mathbf{1 9 9 3}$ & 89,3 & 96,2 & 107,7 \\
$\mathbf{1 9 9 4}$ & 97,3 & 105,5 & 108,4 \\
$\mathbf{1 9 9 5}$ & 95,8 & 105,4 & 110,0 \\
$\mathbf{1 9 9 6}$ & $\mathbf{8 8 , 8}$ & 100,4 & 113,1 \\
\hline
\end{tabular}

Fonte: Mello, F. H. in Preços agricolas, $\mathrm{n}^{0} 131$, set. 97

(a) café, laranja, algodão, soja, milho, batata, feijão e arroz.

Em contrapartida, a participação da indústria no PIB cresceu de 1980 a 1985, caiu entre 1985 a 1991 passando de 43,68 para 36,78 e a partir de 1992 começou a dar sinais de recuperação (Tabela 42). No Brasil como em muitos outros países em desenvolvimento, a indústria foi a força motriz do rápido crescimento econômico no período 1965/80. Entretanto, isso deixou de ocorrer com a crise dos anos 80, quando o crescimento industrial sofreu um colapso. Dados recentes da produção industrial indicam que $\circ$ Brasil está dando sinais de uma mudança de patamar nesse segmento. Comparando dados provenientes dos principais indicadores industriais percebe-se uma convergência das informações no sentido desta mudança (Tabela 45). Segundo o IBGE (1996), O fato de se registrar uma queda na participação da Indústria em 1994, afora o grande crescimento do produto industrial, é explicado pelos ganhos de produtividade do setor.

Fenômeno oposto ao da indústria ocorreu com o setor serviços que diminuiu sua participação no PIB no período de 1980 a 1985, elevou entre 1985 a 1991 atingindo o patamar 


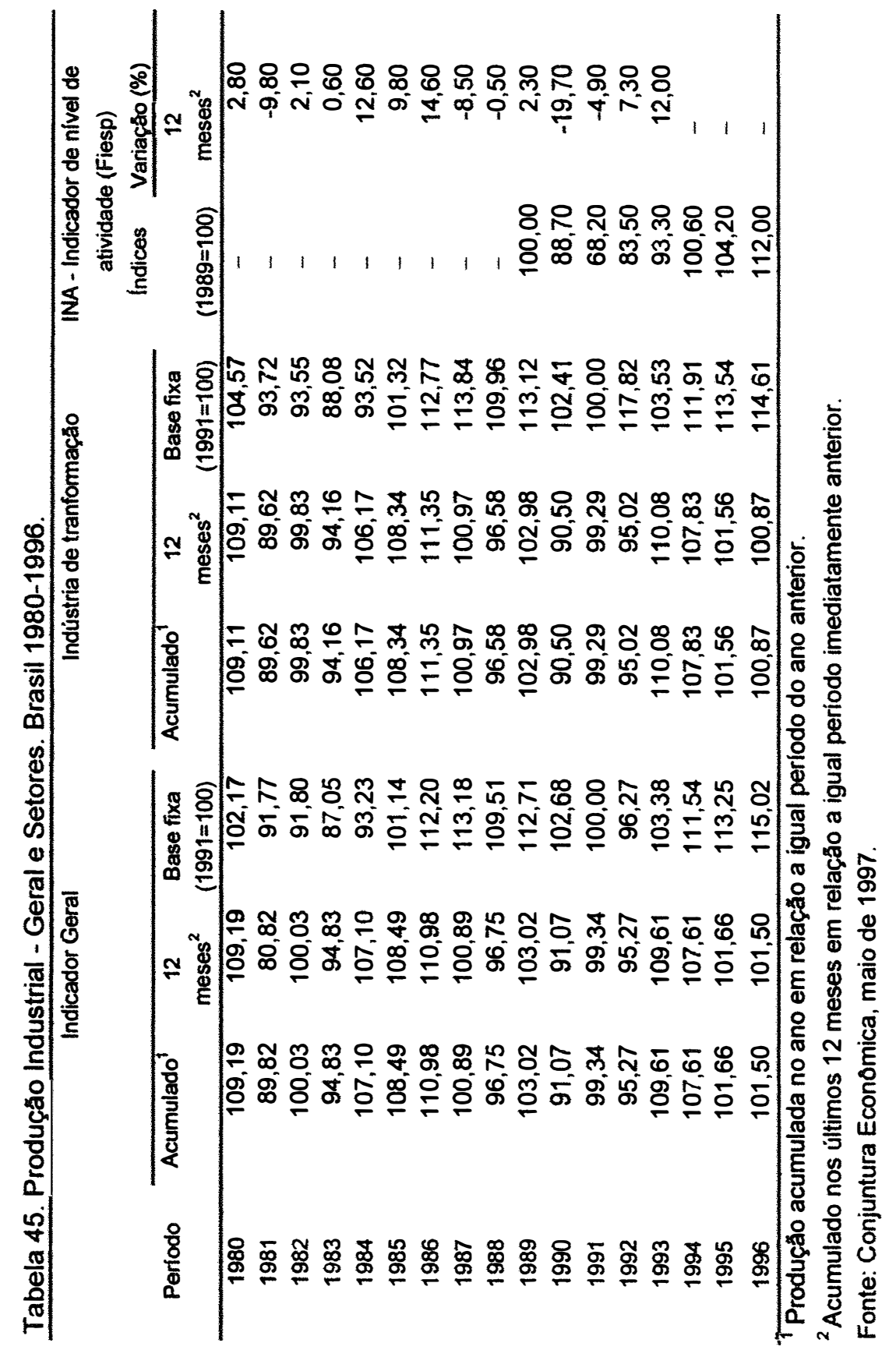




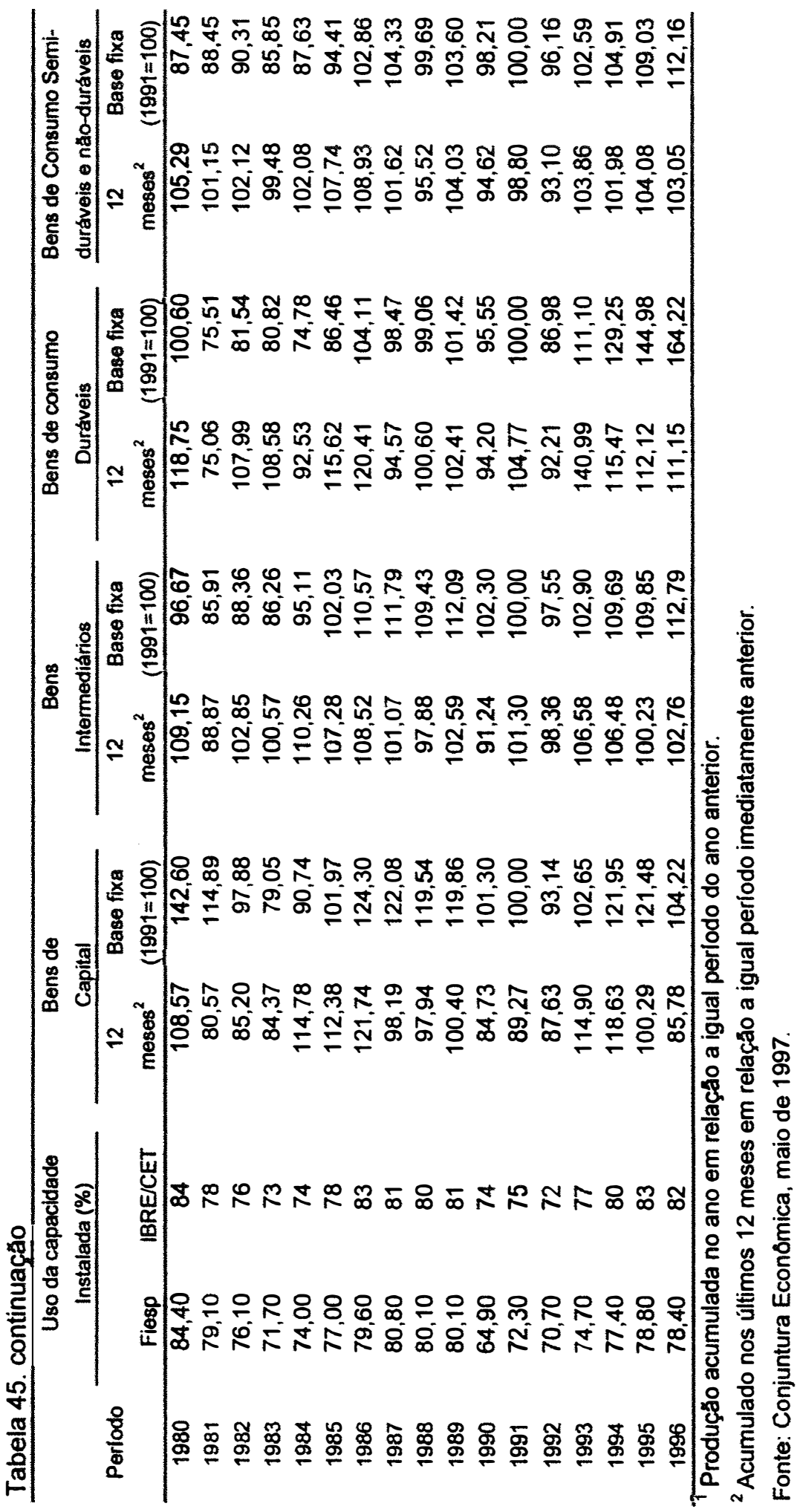


de 55,4\% e vem reduzindo essa participação a partir de então ${ }^{30}$ (Tabela 42).

Se considerarmos a imputação dos serviços de intermediação financeira na participação dos setores no PIBcf, pode-se afirmar que o setor Serviços vem apresentando tendência altista desde 1980 atingindo o nível de 83,2\% em 1993 e caindo drasticamente para 65,4\% em 1994 (Tabela 41). Segundo 0 IBGE (1996) a queda da participação do segmento serviços em 1994 pode ser explicada pela perda de peso das Instituições Financeiras devido à redução dos ganhos a partir da estabilização monetária de julho de 1994. No entanto, os dados devem ser considerados com cautela lembrando sempre de possíveis problemas metodológicos.

É importante chamar a atenção para o fato de que se confrontarmos as estimativas do Produto Interno Bruto da economia brasileira obtidas através das Matrizes InsumoProduto com as do PIB calculados a partir dos censos e divulgados oficialmente pelo IBGE, vamos perceber que os valores em uma e outra ótica são diferentes. Essas diferenças dizem respeito tanto no que se refere ao PIB Global a preços de mercado como a custo de fatores e ficam mais acentuadas quando os resultados são desagregados por classes de atividade econômica, principalmente para a agropecuária. ${ }^{31}$ Se tomarmos o ano de 1994, para comparação, nota-se que para o setor rural o valor estimado através dos dados da matriz de insumo-produto corresponde a 70,76\% da outra estimativa (ver Tabelas 40 e 46 ).

\footnotetext{
${ }^{30}$ Participações dos setores no $\mathrm{PIB}_{\mathrm{cf}}$ calculadas retirando as "imputações dos serviços de intermediação financeira", distribuídas proporcionalmente aos produtos dos setores.

31 As estimativas convertidas para representação em reais (R\$) constam do Apêndice 4.
} 


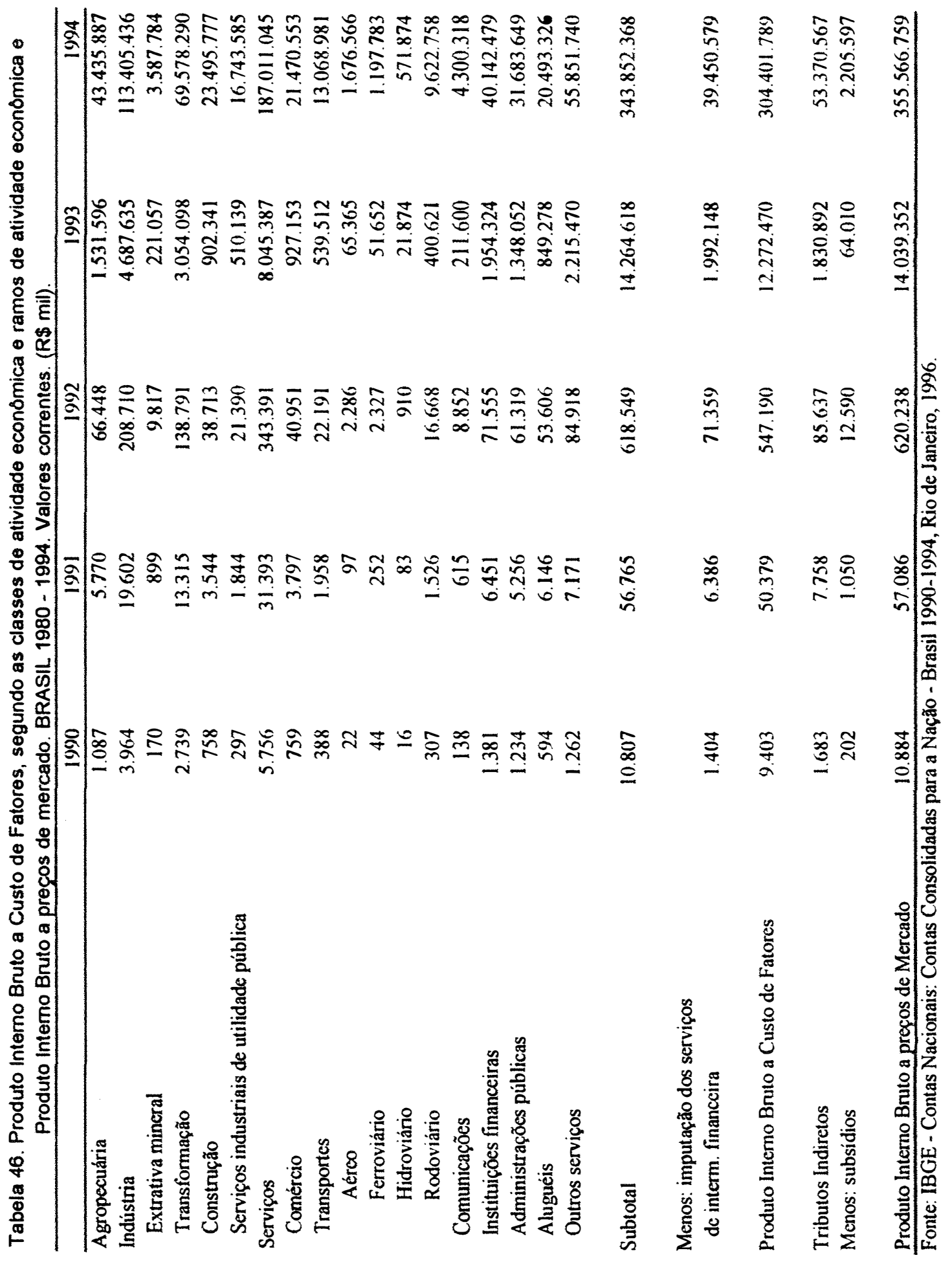


Os resultados do Produto Interno Bruto que têm sido divulgados até o presente momento pelo DECNA referem-se às Contas Consolidadas para a Nação que utilizam metodologia desenvolvida pela Fundação Getúlio vargas (FGV), que era até 1986 o Instituto responsável pelo cálculo das Contas Nacionais do Brasil. Cabe lembrar que a FGV é uma instituição que não realiza levantamentos estatísticos de dados primários se dedicando essencialmente a pesquisa de preços e sondagens conjunturais. Embora esta metodologia tenha sido aperfeiçoada pelo IBGE, quando assumiu a responsabilidade pelas estimativas das Contas Nacionais do País, as formas de cálculos dos agregados econômicos são adaptações da proposta de contas padrão das Nações Unidas (SNA, 1952), não adotando completamente as concepções formuladas na proposta de 1968 das Nações Unidas (IBGE, 1988).

As Nações Unidas, órgão internacional responsável pela normatização dos métodos e procedimentos do Sistema Estatístico de Contas Nacionais, em 1968 realizou uma revisão na metodologia incorporando avanços onde recomendase a substituição do modelo tradicional de mensuração dos agregados macroeconômicos para um sistema amplo e articulado de informações que evidenciam suas relações recíprocas. (IBGE, 1988).

Paralelamente, O IBGE através do Departamento de Contas Nacionais (DECNA), setor responsável pelo cálculo das Contas Nacionais do Brasil, vem desenvolvendo a implantação de um Novo Sistema de Contas Nacionais (NSCN) que irá substituir ao longo do tempo o Sistema de Contas Nacionais Consolidadas (SCNC) .

O Novo Sistema de Contas Nacionais (NSCN) apresenta as vantagens de ser mais abrangente e de ser levantado com 
um nível maior de desagregação em perfeita articulação com a Matriz de Insumo-Produto. Além disso, sua base conceitual e concepção ampla está apoiada nas recomendações das Nações Unidas. Quanto à sua base metodológica vem sendo desenvolvida em consonância com a experiência do sistema Erancês de Contas Nacionais - Systeme Elargi de Comptabilité Nationale, base 1980, Méthodes(IBGE, 1988).

- Sistema integra as Tabelas de Insumo-Produto e Contas dos Setores Institucionais, incluindo contas Financeiras.

No Sistema de Contas Nacionais Consolidadas (SCNC) estimam-se os agregados econômicos com detalhamento do Produto Interno Bruto por atividade econômica.

Resta, afinal, ressaltar que a Matriz de InsumoProduto é a base para a nova estrutura do PIB que permitirá a melhor mensuração das relações sócio-econômicas brasileiras, dotando o País de um sistema de Contas Nacionais Moderno e gerando um quadro de informações dos fluxos de produção e consumo dando condições para estudos de interdependência setoriais.

\subsection{A evolução do complexo agroindustrial e da agricultura nos anos $80 / 94$}

$\mathrm{Na}$ tentativa de quantificar a evolução do complexo agroindustrial no período $80 / 94$ foram calculados o PIB a preços constantes, através de duas formas alternativas, entre as diferentes possibilidades recomendadas para obtenção do Valor Adicionado a preços constantes. ${ }^{32}$

32 Ver Fundação IBGE Sistema de Contas Nacionais Consolidadas. Brasil. Rio de Janeiro, 1990 (Série Relatórios Metodológicos, nº 8). 
A primeira alternativa adota o método denominado de dupla deflação na qual o Valor Adicionado é obtido por saldo entre o Valor da Produção e o Consumo Intermediário deflacionados individualmente. Já, a segunda alternativa realiza a deflação do valor corrente do Valor Adicionado, com índices de preços da produção específicos para as diferentes atividades.

No Sistema de Contas Nacionais Consolidadas (SCNC) - método adotado para cálculo do Produto Interno Bruto das atividades em termos constantes é uma combinação da extrapolação dos valores correntes do valor adicionado, do ano-base, com índices de volume da produção e índices de volume dos insumos.

Define-se formalmente como deflação, o processo de redução de valores monetários de diversas épocas ao valor monetário de uma determinada época tomada como base, utilizando para tal indices de preços selecionados. Por sua vez, denomina-se extrapolação a aplicação de índices de volume que reflitam o crescimento do volume entre dois períodos considerados.

Os resultados dessas estimativas encontram-se nos Apêndices 5 e 6 .

Os cálculos obtidos através da dupla deflação traz limitações, uma vez que apresentam valores negativos para algumas atividades. Esses valores negativos podem estar sinalizando um desequilíbrio nas relações produtivas ocasionado, possivelmente, por alterações na estrutura de preços relativos, referentes ao período 1980 a 1994. Também, é possível uma influência da variação de estoques. É importante mencionar que os indices de preços utilizados para o deflacionamento apresentam uma sistemática de cálculo onde a base permanece inalterada por 
um período de tempo considerável, 0 que pode acarretar distorções na mensuração dos agregados econômicos a preços constantes, principalmente em épocas em que o ritmo da inflação se acelera. Note-se que 0 Índice de Preços ao Atacado - IPA e o Índice Geral de Preços - IGP permanecem com a mesma base de cálculo (1977=100) até maio de 1986, com mudanças de base em dezembro/1989 - dezembro/1992 e agosto/1994. É possível uma interferência técnica devido à forma de cálculo dos índices, por não refletir a nova estrutura de pesos dos insumos produtivos.

Os Índices de Preços por Atacado (IPA) estão organizados para medir a evolução de preços segundo o destino que se atribui aos bens componentes, isto é, tanto para consumo como para produção. O levantamento de preços para os produtos industriais são realizados através de consultas diretas às empresas informantes e referem-se a valores líquidos de vendas à vista, deduzidos os descontos eventuais e acrescidos dos impostos incidentes (FGV, 1994).

$\mathrm{Na}$ sistemática para apuração do Índice de Preços Recebidos pelos produtores Rurais - IPR - as informações de preços recebidos pelos agricultores são coletadas para um conjunto amplo de produtos na maioria dos municípios do território nacional junto as redes estaduais de extensão rural. Com base nas médias aritméticas dos preços coletados, para cada produto, são obtidas as médias estaduais de preços em um dado período $t$. Numa segunda etapa, os relativos desses preços médios estaduais e os apurados no levantamento anterior são ponderados pela participação do valor de cada produto em cada estado, em relação ao valor total da produção agrícola brasileira, de 
acordo com o Censo Agropecuário de 1980 (Agroanalysis, março 87).

Como o tratamento aplicado para o ajuste dos indices é em função de uma avaliação pelo comportamento dos preços da produção média do setor, naturalmente os índices refletem melhor a situação relativa da evolução da produção do que da evolução dos insumos do setor.

Ressalte-se, ainda, que a publicação histórica dos preços recebidos pelos agricultores foi interrompida em dezembro de 1986 e reiniciada com nova composição em janeiro de 1987. Desta forma, o encadeamento realizado da nova série à anterior apresenta riscos metodológicos e devem ser considerados com cautela.

Cabe salientar que $O$ ano de 1980 é o que mais apresenta problemas, sendo que dos 42 setores estimados 11 apresentam sinais negativos do valor adicionado. Para o ano 1985 e 1990 o problema restringe-se a 2 setores somente.

É preciso considerar, também, que os dados da matriz de insumo-produto de 1980 e 1985 baseiam-se em levantamentos realizados (anos censitários) e as matrizes de 1990/95 são projeções anuais que trabalham com a estrutura básica de 1985. O fato dos resultados a partir de 1990 não apresentarem as interferências citadas sugere que com as projeções anuais que $O$ IBGE vem realizando ocorre a superação do problema, com um equilíbrio da estrutura de preços relativos.

Tais problemas podem estar sendo agravados devido a série de tempo considerada ser relativamente longa e o período econômico de grandes oscilações (instabilidades) podendo acarretar uma desarticulação dos dados utilizados. Em relação à segunda forma de deflacionamento adotada observa-se que embora as estimativas obtidas não 
apresentem valores negativos, esse critério não segue as recomendações internacionais de deflacionamento de matrizes. Dessa forma optou-se pelas estimativas através do deflacionamento duplo. Contudo, as informações apresentadas relativas aos valores adicionados a preços constantes devem ser analisadas com reservas.

Fazendo um paralelo com os critérios utilizados pelo IBGE, observa-se que dentro da sistemática de trabalho estabelecida no Novo Sistema de Contas Nacionais (NSCN), "as construções da série corrente das contas de Produção e de Oferta e Demanda de Bens e Serviços, em volume e valor são estimadas, por projeções do ano anterior, utilizando índices de volume e valor. Essas projeções geram planilhas de produtos equilibradas pelo uso da variação de estoque como variável de saldo. São realizados equilíbrios nos resultados baseados nas cadeias de produção e dossiês de cada produto. Nesse equilíbrio são consideradas as relações "valor adicionado/valor da produção" e "consumo intermediário por produto/valor da produção da atividade". A projeção da Tabela de produção, em volume, é feita por produto, utilizando os índices da Pesquisa Industrial Mensal, Pesquisa Agrícola Municipal, Pesquisa de Pecuária Municipal e um conjunto adicional de informações exterior ao IBGE. Por sua vez, a projeção da Tabela de consumo intermediário por atividade, em volume, é feita através dos índices de volume por atividade obtidas das projeções de produção, adotando-se a hipótese de constância dos coeficientes "consumo intermediário/valor da produção". Para a obtenção das Tabelas em valor (preços do ano correntel são utilizados os índices de preços ao atacado/FGV e outras fontes complementares" (IBGE, 1991). 
Os dados sobre o complexo agroindustrial, composto pelo setor agrícola e setores industriais vinculados à agricultura, mostram que o setor expandiu a uma taxa de 9,2\% em média, entre o período 80/85 (Apêndice 7.4), resultado nitidamente inferior aos $22,2 \%$ registrados pela indústria de uma maneira geral (indústria extrativa e de transformação). Esses resultados podem ser melhor visualizados na Figura 22.

Cabe lembrar que a análise realizada adota três versoes para o setor Indústria de base agrícola, assim composto:

Versão $1: 17$ - Eabricação de elementos químicos; 25 Indústria do café; 26 - Beneficiamento de produtos vegetais; 27 - Abate de animais; 28 Indústria de laticínios; 29 - Fabricação de açúcar; 30 -Eabricação de óleos vegetais.

Versão 2 : incluem todas as atividades referentes a Versão 1 mais os setores 14 - Madeira e Mobiliário e 31 Fabricação de outros produtos alimentares.

Versão 3 : incluem todas as atividades da versão 2 mais o setor 22 - Indústria Textil.

Dessa forma, excetuando o setor Agropecuária, tem-se três versões para o total do Complexo Agroindustrial Brasileiro e para os segmentos Indústria para agricultura e Distribuição. 


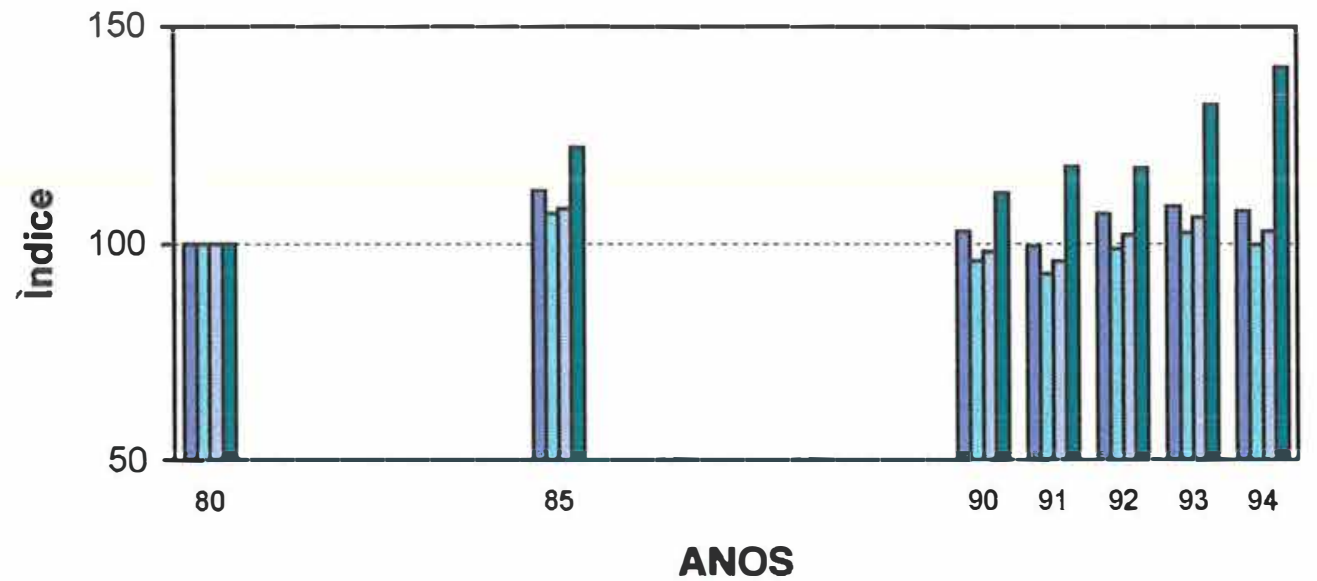

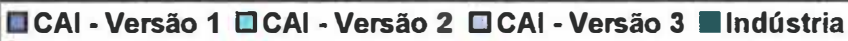

Figura 22. Evolução do Valor Adicionado

Complexo Agroindustrial x Indústria.

Brasil - 1980/94. Base (média $1980=100$ ).

Considerando-se a média das três versões do CAI, os dados mostram que esse ritmo de crescimento no período 80/85 foi sustentado pela agropecuária e pelo setor de distribuição que apresentaram os melhores desempenhos nesse período, entre os segmentos formadores do CAI, 26,8\% e 24,1\%, respectivamente (Apêndice 7.4). No período 1985/90 registra-se um decréscimo de 9,3\% (média), no total do valor adicionado do complexo agroindustrial. Este desempenho negativo, entretanto, é fortemente atrelado ao comportamento do PIB da agropecuária que recuou 19,8\% no mesmo período. Após 1990, o comportamento do CAI foi positivo registrando no período 1991/94 um crescimento de 7,4\% (em média). Essa menor oscilação deve-se a uma relativa estagnação do valor adicionado da agropecuária entre 1990/92, sendo que a queda registrada em 1993 $(-10,1 \%$ foi compensada pelo desempenho positivo do 
segmento de Distribuição Final que entre 1980/93 cresceu, em média, 39,2\% (Apêndice 7.1). No ano de 1994 embora a agropecuária apresente um crescimento do PIB de 14,0\%, os ramos ligados a serviços do CAI contrapõem esse movimento com uma queda de $18,6 \%$, 0 que resultou numa relativa estabilidade do PIB do complexo agroindustrial (Figura 23).

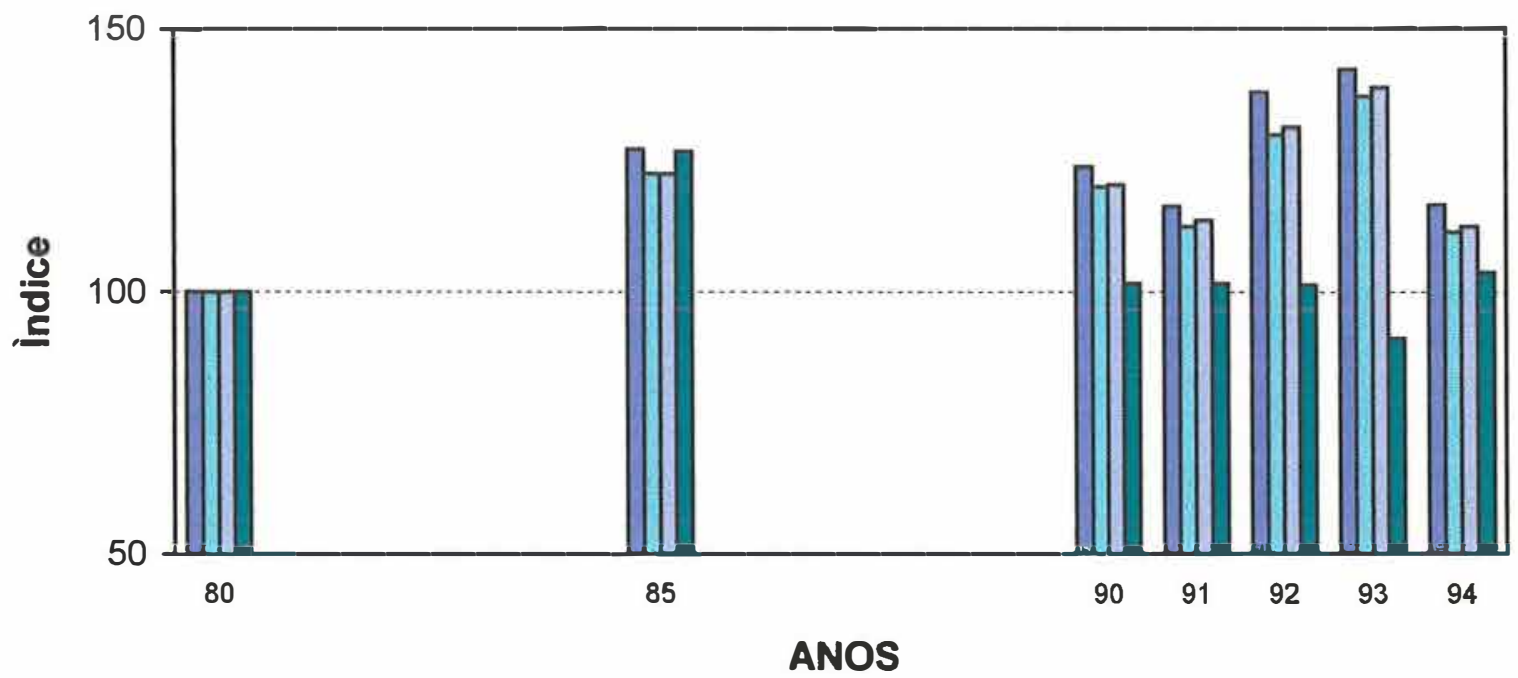

口Versão 1 पVersão 2 पVersão 3 Agropecuária

Figura 23. Evolução do Valor Adicionado Agropecuária x Distribuição Final. Brasil - 1980/94. Base (média $1980=100$ ).

Já do lado da agroindústria, podemos destacar, em primeiro lugar seu movimento descendente ao longo da década de 80, que entretanto foi interrompido no período 1993/94 com um salto de 40,8\% (em média) no PIB, índice bastante superior ao apresentado pelo conjunto da indústria (indústria extrativa e de transformação) cuja taxa de crescimento foi de 19,7\% (Eigura 24). 


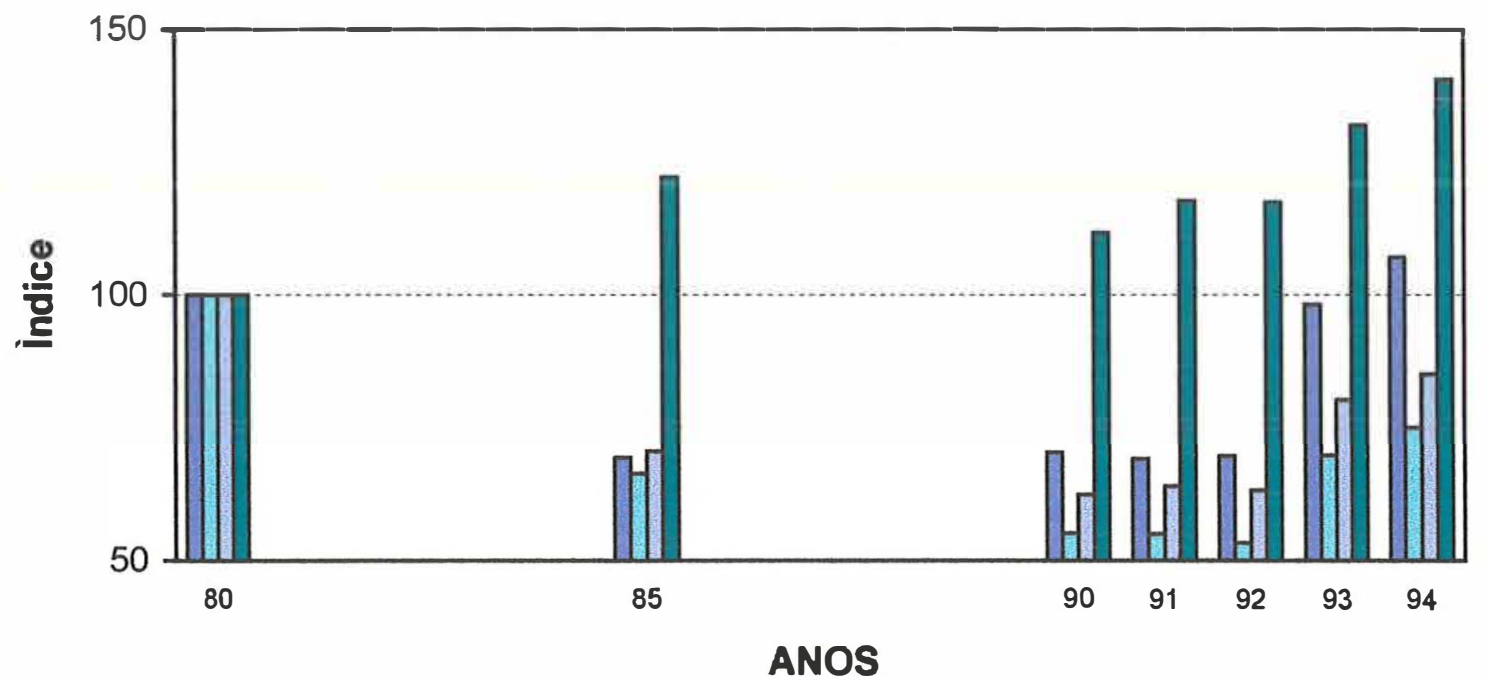

QVersão 1 पVersão 2 पVersão 3 Indústria

Figura 24. Evolução do Valor Adicionado Indústria de Base Agrícola x Indústria.

Brasil - 1980/94. Base (média $1980=100$ ).

Por fim, podemos analisar a evolução do valor adicionado da Indústria para Agricultura, que engloba o conjunto de setores fornecedores de equipamentos e insumos agrícolas, na Eigura 25. Nota-se no período 1980/94, excetuando a versão 1 nos primeiros anos da série (80-85) e do ano de 91, que o nível do valor adicionado desse ramo mostrou uma trajetória suavemente positiva. 


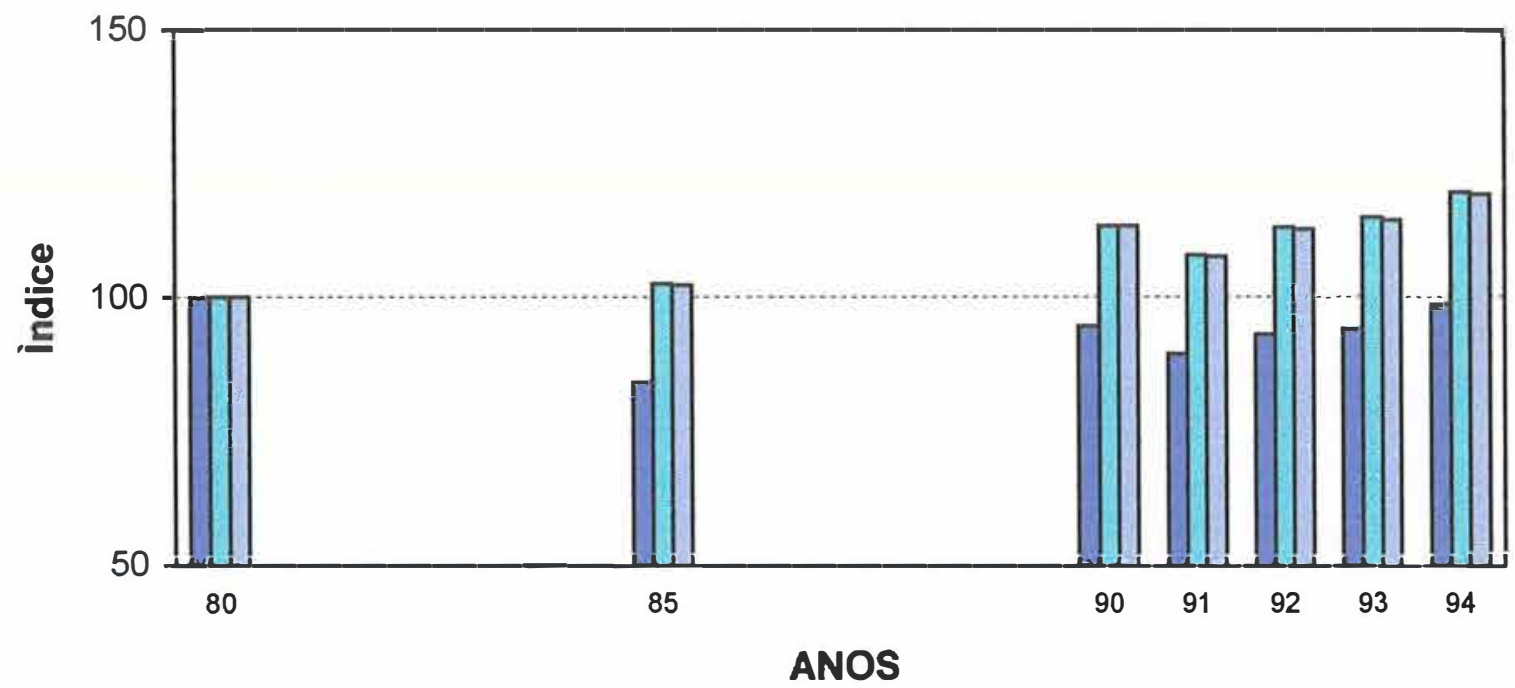

पVersão 1 पVersão 2 पVersão 3

Figura 25. Evolução do Valor Adicionado

Indústria para Agricultura.

Brasil - 1980/94. Base (média $1980=100$ ).

Este comportamento pode ser explicado pelo fato de que a demanda por insumos agrícolas está associada fortemente a evolução dos índices de preços reais de insumos que apresenta expressiva redução no período (Tabela 47 ). 
Tabela 47. Evolução dos indices de preços reais de insumos agricolas no Brasil, 1987/97. (1994=100).

\begin{tabular}{ccccc}
\hline \multicolumn{1}{c}{ INSUMOS } & FERTILIZANTES & AGROTÓXICOS & COMBUSTIVEIS & IPP-BRASIL \\
\hline $\mathbf{1 9 N O}$ & 147,28 & 103,09 & 95,24 & 113,90 \\
$\mathbf{1 9 8 8}$ & 131,35 & 96,14 & 86,78 & 100,63 \\
$\mathbf{1 9 8 9}$ & 120,85 & 95,16 & 56,38 & 91,97 \\
$\mathbf{1 9 9 0}$ & 109,13 & 85,67 & 64,65 & $\mathbf{8 8 , 9 1}$ \\
$\mathbf{1 9 9 1}$ & 100,26 & 89,92 & 64,47 & 88,58 \\
$\mathbf{1 9 9 2}$ & 93,70 & 90,26 & 84,29 & 88,07 \\
$\mathbf{1 9 9 3}$ & $\mathbf{7 6 , 7 5}$ & 79,81 & 81,73 & $\mathbf{7 8 , 0 4}$ \\
$\mathbf{1 9 9 4}$ & 69,59 & 69,66 & 69,38 & $\mathbf{7 1 , 4 4}$ \\
$\mathbf{1 9 9 5}$ & 66,41 & 62,82 & 60,81 & $\mathbf{7 5 , 1 5}$ \\
$\mathbf{1 9 9 6}$ & $\mathbf{7 0 , 3 8}$ & 61,22 & 59,41 & $\mathbf{7 7 , 4 7}$ \\
$\mathbf{1 9 9 7}$ & 69,56 & 60,83 & 61,73 & $\mathbf{7 7 , 7 6}$ \\
\hline
\end{tabular}

Base: agosto de $1994=100$

Deflator: IGP/DI.

Fonte: Dados básicos do IBGE.

Elaborados pela autora.

$\mathrm{Na}$ Eigura 26 pode-se observar a evolução da trajetória da produção de alguns produtos componentes do setor Indústria para Agricultura. 


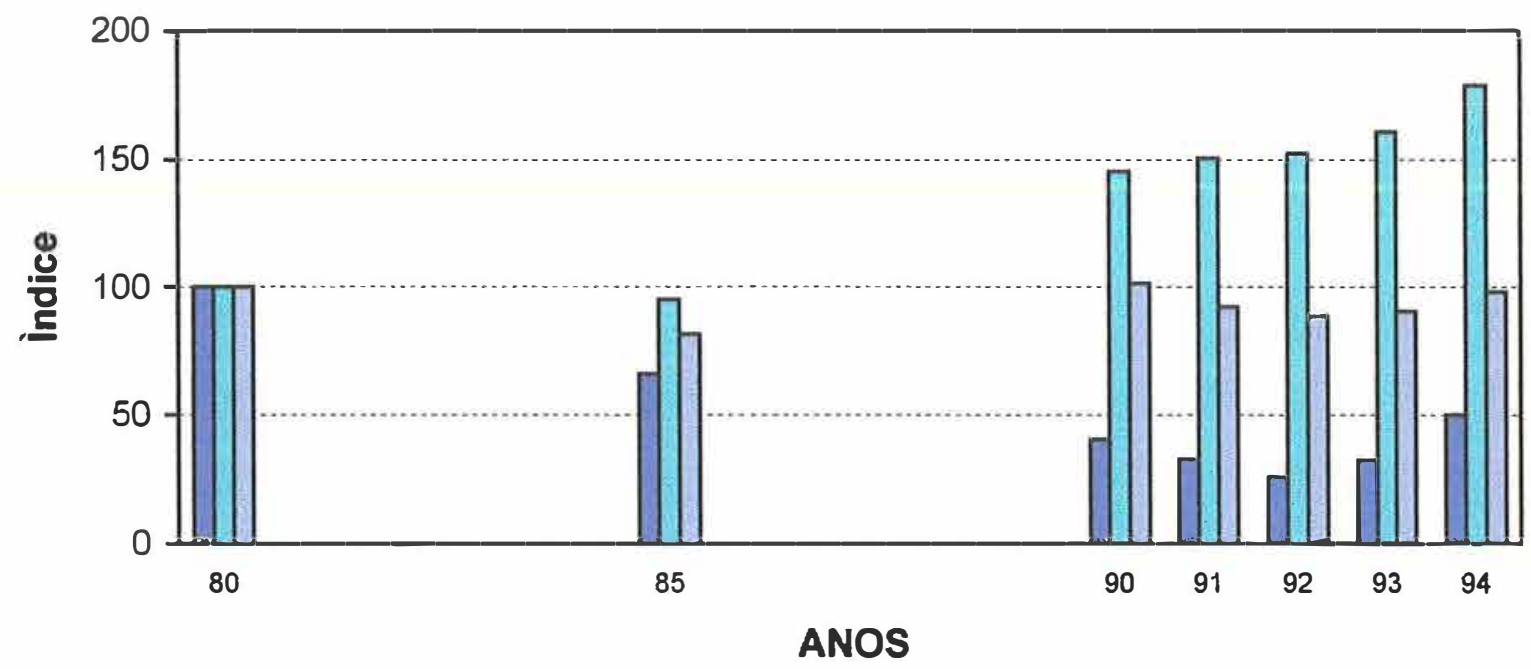

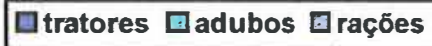

Figura 26. Evolução do Nivel de Produção de Produtos Vinculados a Agropecuária.

Brasil - 1980/94. Base (média $1980=100$ ).

Vale destacar que o comportamento da indústria de tratores cresceu basicamente nos dois últimos anos (93/94). Em relação a produção de adubos e fertilizantes, pode-se dizer que ao longo do período analisado (80/94) a tendência da produção foi crescente, 79,0\% (Apêndice 10.3).

Comparando-se a "performance" dos produtos agrícolas com os produtos animais da agropecuária (Figura 27), nota-se que no caso dos produtos agrícolas a produção teve acentuado aumento durante 1980/85 apresentando relativa estagnação no período $1990 / 92$ e expansão em 1994. Já para a produção animal o resultado é uma tendência de aumento até 1992 com redução em 93 e 94 (Apêndice 9.3). 


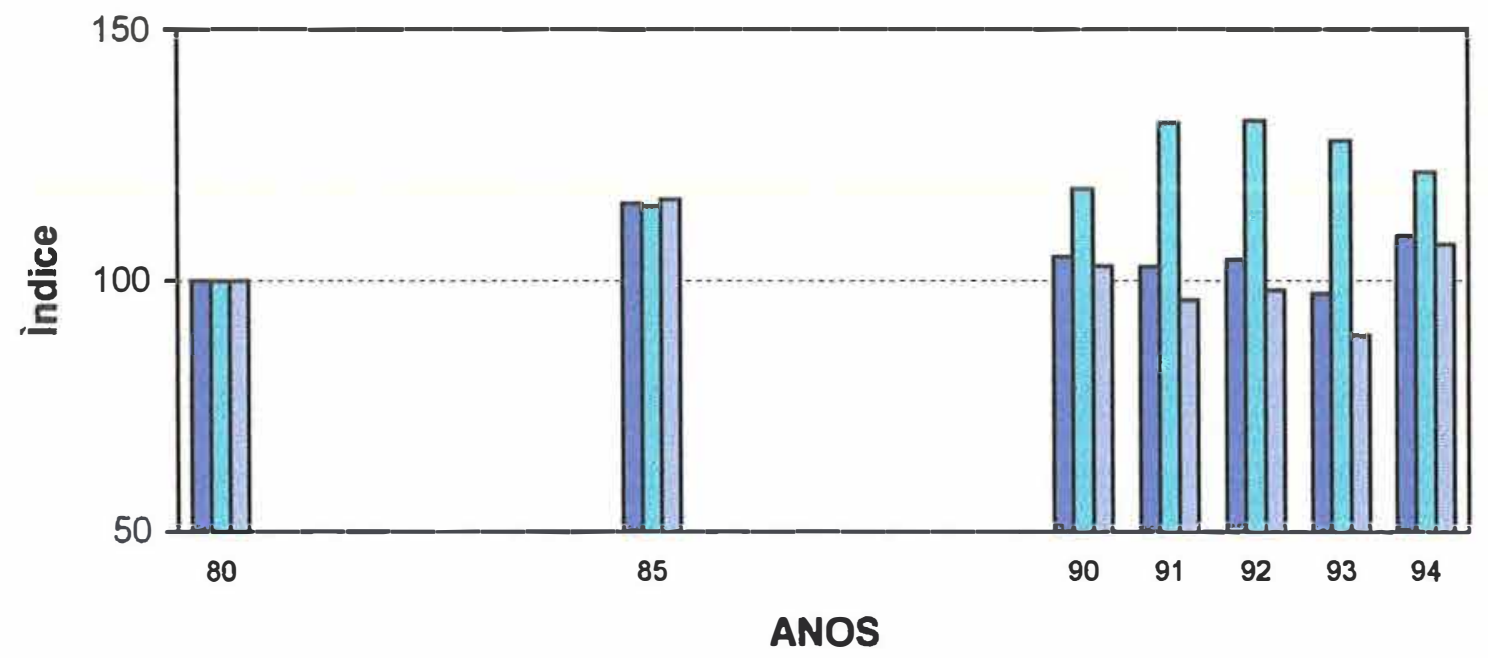

口Agropecuária DProd. animal total $\square$ Prod. agrícola total

Figura 27. Evolução do Nível de Produção da Agropecuária Brasil - 1980/94. Base (média $1980=100$ ).

Conforme argumentam Bacha e Rocha (1997), o comportamento ascendente da pecuária brasileira se deve tanto ao aumento do número de animais abatidos como a elevação do "rendimento de carne por animal abatido".

Finalmente, $\quad$ confronto entre os agregados formadores do CAI, através da evolução do PIB, mostra que entre 1980/94 o agregado IV (Distribuição Final) foi o setor com melhor desempenho, totalizando um incremento de 13,5\% (Apêndice 7). Nesse sentido os resultados sugerem a tendência da sempre maior participação do segmento a jusante no CAI, isto é, o setor de armazenamento, processamento e distribuição final que passa a ser o grande intermediário entre o produtor e o consumidor. Contudo, é importante perceber que o produtor rural exerce função essencial nesse processo e participa em cerca de 30\% do valor gerado pelo mesmo. 


\section{CONCLUSŌES}

Da análise dos dados das matrizes de insumoproduto, no período 1980-85-90, pode-se inferir que vem aumentando a complexidade da economia brasileira apresentando um estágio avançado de estrutura produtiva com um alto grau de interligação entre os setores produtivos nacionais.

A análise dos índices de encadeamento da economia brasileira, para os anos 80,85 e 90, através de diferentes técnicas, mostra o predomínio dos setores Siderurgia, Metalurgia e Agropecuária em quase todos os enfoques. Alguns setores que compõem 0 segmento de Produtos alimentares, também, assumem papel de importância dentro das relações intersetoriais, no que diz respeito ao encadeamento para trás. Ademais, a influência de setores como Papel - Papelão e Têxtil é captada pelo enfoque de Rasmussen-Hirschman. Os resultados apontam para uma crescente importância do segmento Serviços dentro da economia, seguindo a tendência deste ramo em economias desenvolvidas.

$\mathrm{Na}$ abordagem de Campo de Influência, conceito que fornece o grau com que pequenas mudanças nos coeficientes de produção podem afetar o resto do sistema, os resultados indicam que as relações da economia brasileira são dominadas essencialmente pelos setores siderurgia e 
Agropecuária, enquanto a Indústria Têxtil aparece como o terceiro setor influente.

Para o procedimento analítico alternativo de delimitação dos componentes do Complexo Agroindustrial, estimam-se as matrizes AGR que permitem identificar as interrelações entre as atividades agropecuárias e os demais setores da economia, em termos dos impactos diretos e indiretos.

As interligações da atividade agropecuária com os setores produtivos do país, em termos de compra de produtos e insumos, ou seja, os efeitos diretos e indiretos para trás da cadeia produtiva agrícola, mostram que cerca de $80 \%$ dos impactos englobam os seguintes setores, nos três períodos analisados: 8 - Eabricação e Manutenção de máquinas e tratores; 17 - Fabricação de elementos químicos; 18 - Refino do petróleo; 19 - Eabricação de produtos químicos diversos; 30 - Fabricação de óleos vegetais; 31 -Fabricação de outros produtos alimentares; 35 - Comércio; 36 - Transporte; 40 - Serviços prestados às empresas. Esses resultados apontam uma maior interligação para trás da agropecuária com os segmentos fornecedores de "máquinas e tratores", "adubos e fertilizantes", "óleos combustíveis", "tortas e farelos", "rações balanceadas" e "serviços".

Quando se considera os setores demandantes de produtos agrícolas, observa-se que as coincidências entre os períodos analisados se concentram em 11 setores, os quais juntos representam aproximadamente $80 \%$ dos efeitos diretos e indiretos das atividades econômicas sobre a agropecuária. Assim, têm-se os seguintes setores compondo o conjunto da Indústria de Base Agrícola: 14 - Madeira e 
mobiliário; 17 - Fabricação de elementos químicos; 22 Indústria têxtil; 25 - Indústria do café; 26 Beneficiamento de produtos vegetais; 27 - Abate de animais; 28 - Indústria de laticínios; 29 - Fabricação de açúcar; 30 - Fabricação de óleos vegetais; 31 - Fabricação de outros produtos alimentares; 39 - Serviços prestados às famílias.

Esses resultados confirmam a grande articulação entre os setores componentes do CAI, refletindo a importância da atividade agrícola como setor de grande influência na estrutura produtiva da nação através dos altos efeitos de encadeamento a montante e a jusante.

Uma comparação da composição dos setores formadores do CAI a partir das estimativas da matriz AGR com outros procedimentos usualmente utilizados mostra que a abordagem matricial é uma ferramenta adequada como método de delinear - CAI, podendo ser utilizada tanto isoladamente como de forma complementar a outros procedimentos. Desta forma, o método seguido neste trabalho pode ser de utilidade em futuros estudos, norteando pesquisas sobre 0 complexo agroindustrial brasileiro.

Em relação aos resultados do CAI, os dados empíricos mostram $\bigcirc$ papel fundamental que o "agribusiness" brasileiro tem desempenhado na economia nacional respondendo por cerca de $32 \%$ do produto interno bruto.

A análise da composição do Complexo Agroindustrial Brasileiro reafirmou as tendências históricas observadas na evolução do "agribusiness" em economias desenvolvidas, sendo um fenômeno que ocorre também em países em desenvolvimento. No caso brasileiro, tem sido um processo muito intenso. 
Vistos de uma perspectiva desagregada, os resultados mostram a expressiva perda de peso da Agropecuária no PIB do Complexo Agroindustrial, medido a custo de fatores, no período $1980 / 93$ enquanto a Indústria de Base agrícola e o segmento responsável pela Distribuição dos produtos sobressaem-se como pólos mais dinâmicos, liderando esse processo de transformação agrária.

Fenômeno oposto ao da Indústria de Base agrícola e de Distribuição Final ocorre com a Indústria para Agricultura que diminui gradativamente sua participação no PIB no mesmo período. O menor dinamismo do setor de insumos, depois de totalmente tecnificada a estrutura do CAI, se justifica pela sempre maior participação da Indústria de Base Agrícola e de Distribuição Final.

A evolução da composição do Complexo Agroindustrial Brasileiro são confirmadores de que $\bigcirc$ "agribusiness" adiciona valor às matérias primas agrícolas onde o setor de armazenamento, processamento e distribuição final tende a ser sempre mais representativo no valor total da produção vendida ao consumidor.

Nesse sentido, é fundamental levar em conta a necessária organização dos produtores rurais em associações, cooperativas ou outras formas alternativas de apoio ao produtor rural, na medida em que possibilita ao trabalhador rural enfrentar os desafios desse novo padrão agrário, que leva a uma redução relativa do setor rural em relação aos outros componentes do CAI.

Apesar dessas evidencias caracterizarem as tendências do setor agroindustrial brasileiro cabe ressaltar que o ano de 1994 trouxe uma perspectiva nova para a composição do CAI. A agropecuária registra um aumento de participação no PIB retornando aos níveis 
praticados no início dos anos 80 . Os fatores explicativos desse comportamento podem ser encontrados na trajetória de evolução da relação preços recebidos/preços pagos para a agropecuária e dos preços relativos agrícolas/industriais que no periodo apresentaram tendência altista. Outra variável que pode estar causando essa melhora no desempenho agrícola, possivelmente, é o aumento físico da quantidade produzida no setor rural, ocasionada em grande parte pelo crescimento da produtividade da terra. Além disso, cabe salientar o tipo de ajustamento estrutural pelo qual passou a economia brasileira a partir dos anos 80. Deve-se mencionar, também, a possibilidade de problemas metodológicos ocasionando esses resultados.

Os cálculos do PIB a preços constantes obtidos através da dupla deflação trazem limitações, uma vez que apresentam valores negativos para algumas atividades em alguns periodos. Esses valores negativos podem estar sinalizando um desequilíbrio nas relações produtivas ocasionado, possivelmente, por alterações na estrutura de preços relativos, referentes ao período 1980/94. Também, é perfeitamente possível influência da variação de estoques.

Tais problemas podem estar sendo ocasionados devido a série de tempo considerada relativamente longa e o período econômico de grandes oscilações, podendo acarretar uma desarticulação dos dados utilizados. O fato dos resultados a partir de 1990 não apresentarem as interferências citadas sugere que com as projeções anuais que $\bigcirc$ IBGE vem realizando ocorre a superação do problema, com um equilíbrio da estrutura de preços relativos.

Em relação à segunda forma de deflacionamento adotada para a quantificação da evolução do CAI observa-se que embora as estimativas obtidas não apresentem valores 
negativos, esse critério não segue as recomendações internacionais de deflacionamento de matrizes. Dessa forma optou-se pelas estimativas através do deflacionamento duplo.

De uma maneira geral, os dados sobre o complexo agroindustrial mostram que o setor expandiu, na primeira metade dos anos 80, sustentado pela agropecuária e pelo setor de distribuição que apresentaram os melhores desempenhos. No período 85/90 registra-se um decréscimo de cerca de 9,3\% no total do valor adicionado do CAI. Após a década de 80 , seu movimento apresentou menor variabilidade.

Finalmente, $O$ confronto entre os agregados formadores do CAI, através da evolução do PIB, mostra que entre 1980/94 O agregado IV (Distribuição Final) foi o setor com melhor desempenho. Nesse sentido os resultados sugerem a tendência da sempre maior participação do segmento a jusante no CAI, isto é, o setor de armazenamento, processamento e distribuição final que passa a liderar as relações produtor-consumidor. Contudo, é importante frisar que $\circ$ produtor rural exerce função essencial nesse processo e participa em cerca de 30\% do valor gerado pelo mesmo.

$\mathrm{Na}$ presente pesquisa considera-se o cálculo do Produto Interno Bruto (PIB) para o sistema agroindustrial como um todo. As limitações impostas pela metodologia adotada referem-se ao fato de se estimar indiretamente tanto o valor adicionado do agregado I (Indústria para a agricultura) como $\circ$ do agregado IV (setor de Distribuição Final), o que na verdade reflete um problema da estrutura dos dados básicos.

É preciso lembrar, também, as dificuldades operacionais de avaliação impostas pela agregação de alguns 
setores importantes na cadeia agroindustrial e que englobam atividades muito heterogêneas.

Não constituiu objetivo do trabalho a averiguação da contribuição por produto dentro de cada um desses subsetores os quais poderiam ser analisados em novas pesquisas nesta área. Também seria de interesse 0 desenvolvimento de metodologia para o cálculo do PIB trimestral do complexo agroindustrial brasileiro. 


\section{REFERÊNCIAS BIBLIOGRÁFICAS}

AGROANALYSIS. Rio de Janeiro: Fundação Getúlio Vargas. Instituto Brasileiro de Economia, Março 87.

ALVES, E. Transformações da agricultura brasileira. BraSilia: CODEVASE/M.A., 1989.

AMARO, A.A. et al. Agroindústria e desenvolvimento no Estado de São Paulo: aspectos conceituais. Relatório de Pesquisa. IEA, n. 31, 1987.

ARAÚJO, N. B.; WEDEKIN, I.; PINAZZA, L. A. Complexo agroindutrial: 0 agribusiness brasileiro. São Paulo: Agroceres, 1990. $238 \mathrm{p}$.

BACHA, C. J. C.; ROCHA, M. T. Aumenta a participação da agropecuária no PIB brasileiro. Preços Agrícolas, v. 11, n. 124, p. 3-5, 1997.

CASTRO, A. B. Agricultura e desenvolvimento no Brasil. In:

7 Ensaios sobre economia brasileira. Rio de Janeiro: Forense, 1969. P. 81-146.

BARROS, G. S. de C. Agroindústria e comercialização. In: CONGRESSO BRASILEIRO DE ECONOMIA E SOCIOLOGIA RURAL, 23, São Paulo, 1985. Anais. Brasília: SOBER, 1985. V. 1 BARROS, J. R. M. de et al. Perfil técnico-econômico do setor de fertilizantes. São Paulo: IPT/Centro de Estudos de Fertilizantes, 1980.

BARROS, J. R. M. de. Transição e descontinuidade no crescimento agrícola. In: DIAS, G. L. da S.; BARROS, J. R. M. de. Fundamentos de uma nova politica agrícola. Bra- 
Sília: Companhia de Einanciamento da Produção, 1983. (Coleção Análise e Pesquisa, 26).

BARROS, J. R. M. de; MANOEL, A. Insumos agrícolas: evolução recente e perspectivas. In: BRANDÃO, A. S. P. Os principais problemas da agricultura brasileira: análise e sugestões. Rio de Janeiro: IPEA, 1992. (Série PNPE. IPEA, n. 18).

BAUM, M. Substituição de importações. Uma nova fase da indústria de fertilizantes. São Paulo, 1997. 244 p. Tese (Mestrado) - Universidade de São Paulo/Instituto de Pesquisas Econômicas.

BULMER-THOMAS, $V$. Input-output analysis in developing countries: source, methods and application. New York: Wiley, 1982 .

CELLA, G. The input-output measurement of interindustry linkages. Oxford Bulletin of Economics and Statistics, v. 46, p. 73-84, 1984 .

CONJUNTURA ECONÔMICA. Rio de Janeiro: FGV. dez./83 fev./86 - set./88 - abr./90 - dez./92 - ago./93 Nov./94 - jun./96.

CONTADOR, C. R.; EERREIRA, L. R. Insumos modernos na agricultura brasileira. Rio de Janeiro:IPEA/INPES, 1984 (Textos para Discussão Interna, 65).

DAVIS, J. H.; GOLDBERG, R. A. A concept of agribusiness. Boston: Harvard University, 1957. $135 \mathrm{p}$.

DELGADO, G. Capital financeiro e agricultura no Brasil. São Paulo: Ícone, 1985. 240 p.

DIAS, G. L. S. O papel da agricultura no processo de ajustamento. In: CONGRESSO BRASILEIRO DE ECONOMIA E SOCIOLOGIA RURAL, 27., Piracicaba, 1989. Anais. Brasília: SOBER, 1989. p. 310-17 (nota adicional).

EARINA, E. M. M. Q. O Sistema agroindustrial de alimentos. In: ENCONTRO NACIONAL DE ECONOMIA, 16., Belo Horizonte, 
1988. Arais. Rio de Janeiro: ÄNPEC, 1988. v. 3, p. 292315.

FARINA, E. Q. M. \& ZYLBERSTAJN, D. Relações tecnológicas e organização dos mercados no sistema agroindustrial de alimentos. In: TEIXEIRA, E. C. Politica agricola e desenvolvimento. Viçosa: UEV - EAPEMIG, 1992. p. 73-94. FERREIRA Fo. J. B. S. Ajustamento estrutural e crescimento agricola na década de oitenta: notas adicionais, 1997. FONSECA, M. da G. D. Trajetórias tecnológicas, investimentos e padrões técnicos na agricultura. Uma investigação sobre relações intersetoriais. Campinas: IE/UNICAMP, 1987. (mimeo).

FRANK, A. G. Capitalism and under development in Iatin American: historical studies of Chile and Brazil. New York: Monthly Review Press, 1967.

FUNDAÇÃO GETÚLIO VARGAS. Índice Geral de Precos - Disponibilidade Interna: Metodologia. Rio de Janeiro: IBE/CEP, 1994.

FUNDAÇÃO INSTITUTO BRASILEIRO DE GEOGRAFIA E ESTATÍSTICA. Novo Sistema de Contas Nacionais: Metodologia e resultados provisórios. ano-base 1980. Rio de Janeiro: IBGE, 1988 (Texto para discussão, n. 10).

FUNDAÇÃO INSTITUTO BRASILEIRO DE GEOGRAFIA E ESTATÍSTICA.

Matriz de Relações Intersetoriais: Brasil 1980. Rio de Janeiro:IBGE, 1989. (Texto para discussão, n. 14). FUNDAÇÃO INSTITUTO BRASILEIRO DE GEOGRAFIA E ESTATÍSTICA.

Sistema de Contas Nacionais Consolidadas - Brasil. Rio de janeiro: IBGE, 1989. (Texto para discussão, n. 17). FUNDAÇÃO INSTITUTO BRASILEIRO DE GEOGRAFIA E ESTATÍSTICA. Sistema de Contas Nacionais Consolidadas - Brasil. Rio de Janeiro: IBGE, 1990. (Série Relatórios Metodológicos, v. 8). 
FUNDAÇÃO INSTITUTO BRASILEIRO DE GEOGRAFIA E ESTATÍSTICA.

Produto Interno Bruto - Brasil. Rio de Janeiro: IBGE, 1990. (Série Relatórios Metodológicos, v. 9).

FUNDAÇÃO INSTITUTO BRASILEIRO DE GEOGRAFIA E ESTATÍSTICA.

Novo Sistema de Contas Nacionais. Séries Correntes:

1981-85. Metodologia, resultados provisórios e avaliação do projeto. Rio de Janeiro: IBGE, 1991. (v. 1, n. 51). FUNDAÇÃO INSTITUTO BRASILEIRO DE GEOGRAFIA E ESTATÍSTICA.

Contas Nacionais - Contas Consolidadas para a Nação -

Brasil 1990-1994. Rio de Janeiro: IBGE, 1996.

FUNDAÇÃO INSTITUTO BRASILEIRO DE GEOGRAFIA E ESTATÍSTICA.

Matriz de Insumo-Produto: Brasil 1990. Rio de Janeiro: FIBGE, 1996.

FUNDAÇÃO SISTEMA ESTADUAL DE ANALLISE DE DADOS (SEADE).

Agroindústria Paulista. São Paulo: SEADE, 1990. 59 p. (Coleção Economia Paulista, v. 3).

FURTADO, C. Dialética do desenvolvimento. 2. ed. Rio de Janeiro: Fundo de Cultura, 1964.

FURTADO, C. Formação Econômica do Brasil. 4. ed. São Paulo: Nacional, 1976.

GOLDBERG, R. A. Agribusiness coordination. Boston: Harvard University, 1968. 256 p.

GOLDBERG, R. Agribusiness deve crescer, diz Goldberg. 0

Estado de São Paulo, Så Paulo, 9 dez. 1990. p. 16. (Caderno de Economia).

GUAZIROLE, C. E. Diretrizes de politica agrária e desenvolvimento sustentado. Brasilia: INCRA/FAO, 1994. 25 p. GUILHOTO, J. J. M. Mudanças estruturais e setores-chave na economia brasileira, 1960-1990. In: ENCONTRO BRASILEIRO DE ECONOMETRIA, 14., Campos do Jordão, 1992. Anais, Rio de Janeiro, Sociedade Brasileira de Econometria, 1992. v. 1, p. 293-310. 
GUILHOTO, J. J. M.; PICERNO, A. E. Estrutura produtiva, setores-chave e multiplicadores setoriais: Brasil e Uruguai comparados. Revista Brasileira de Economia, v. 49, n. 1, p. 35-61, 1995.

GUILHOTO, J. J. M. et al. Indices de ligações e setoreschave na economia brasileira: 1959/80. Pesquisa Planejamento Econômico, v. 24, n. 2, p. 287-314, 1994.

GUILHOTO, J. J. M. et al. Linkages and mutipliers in a multiregional framework: integration of alternative approaches. Regional Economics Applications Laboratory. Discussion paper. 96-T-8, 1996.

GUIMARÃES, A. P. Quatro séculos de latifúndio. São Paulo: Fulgor, 1977. 362 p.

GUIMARÃES, A. P. A crise agrária. Rio de Janeiro: Paz e Terra, 1979.

HEWINGS, G. J. D. The empirical identification of key sectors in an economy: a regional perspective. The Developing Economies, v. 20, p. 173-195, 1982.

HEWINGS, G. J. D. et al. Key sectors and structural change in the Brazilian economy: a comparison of alternative approaches and their policy implications. Journal of Policy Modeling, v. 11, p. 67-90, 1989.

HIRSCHMAN, A. $O$. The strategy of economic development. New Haven: Yale University Press, 1958.

JANK, M. S. Mudanças no padrão de crescimento e dinâmica de ajuste externo do setor agroindustrial. In: CONGRESSO BRASILEIRO DE ECONOMIA E SOCIOLOGIA RURAL, 28., Florianópolis, 1990. Arais. Brasília: SOBER, 1990, p. 297307.

JANK, M. S. et al. Introdução ao agribusiness. Apostila de Economia e Administração Agroindustrial. Série didática. DESR.esALQ, n. 96, 1995. 
KAGEYAMA, A. Modernização, produtividade e emprego na agricultura - Uma análise regional. 1985. 463 p. Tese (Doutorado) - Universidade de Campinas.

KAGEYAMA, A. et al. O novo padrão agrícola brasileiro: do complexo rural aos complexos agroindustriais. In: DELGADO, G. et al. (orgs.). Agricultura e Politicas Públicas. Brasilia: IPEA, 1990. (Relatório, n. 127).

LAMBERT, J. Os Dois Brasis. 3. ed. São Paulo: Brasiliana, 1967.

LAUCHNER, R. Agribusiness cooperativa e produtor rural. Rio Grande do Sul -São Leopoldo: Editora da Universidade do Vale do Rio dos Sinos, 1993. 296 p.

LEITE, S. Agricultura. Relações intersetoriais e encadeamentos produtivos. In: CONGRESSO BRASILEIRO DE ECONOMIA E SOCIOLOGIA RURAL, 28. Florianópolis, 1990. Anais. Brasilia, sociedade Brasileira de Economia e Sociologia Rural, 1990, v. 1. p. 61-84.

LEONTIEF, W. Exports, imports, domestic output, and employment. The Quarterly Journal of Economics, v. 60, n.2, p. 171-93, 1946.

LEONTIEF, $W$. The structure of the American economy. 2. ed. New York: Oxford University Press, 1951.

LOPES, M. R. As politicas macroeconômicas e o setor agricola. In: SEMINÁRIO SOBRE PROBLEMAS E PERSPECTIVAS DA AGRICULTURA BRASILEIRA, 3. Piracicaba, 1987. Anais. Piracicaba: ESALQ/FEALQ, 1987. p. 66-78.

MALASSIS, L. Developpement economique et industrialisation de l'agriculture. Economie Appliquée, t. $21, \mathrm{n} .1$, 1968 .

MALASSIS, L. La structure et l'évolution du complexe agriindustriel d'aprés la comptabilité nationale française. Économies et Sociétés, v. 3, n. 9, p. 1667-1687, 1969. 
MALASSIS, L.; PADILLA, M. Traité d'économie agroalimentaire, Paris: Cuyas, 1986.

MANOEL, A.; BARROS, J. R. M. de. Agricultura brasileira: transformação e perspectiva na década de 80 . In: ENCONTRO NACIONAL DE ECONOMIA, 15., Salvador, 1987. Anais. Salvador: ANPEC, $1987 . \mathrm{V} .2$.

MELO, F. H. de. Efeitos negativos da politica cambial sobre a produção agrícola. Preços Agrícolas, v. 11, n. 131, p. 4-6, 1997.

MCGILVRAY, J. Linkages, key sectors and development strategy. In: LEONTIEF, W. (ed.). structure, system and economic policy. Cambridge: Cambridge University Press, 1977 .

MILLER, R. E.; BLAIR, P.D. Input-output analysis: foundations and extensions. Englewood cliffs: Prentice Hall, 1985 .

MÜLLER, G. Agricultura e Industrialização do Campo no Brasil. Revista de Economia Politica, v. 2, n. 6, p. 4777, abr./jun. 1982.

MÚLLER, G. Complexo agroindustrial e modernização agrária. São Paulo: Hucitec, 1989. 148 p.

NETTO, D. Agricultura e desenvolvimento no Brasil. Estudos ANPES, $\mathrm{n} .5,1966$.

OLIVEIRA, A. L. B. de. O desenvolvimento planificado da economia brasileira. Rio de Janeiro: Fundação Getúlio Vargas, 1946.

OMETTO, A. M. H.; FuRTuOso, M. C. O.; SilVA, M. V. da. Economia Brasileira na década de oitenta e seus reflexos nas condições de vida da população. Revista de saúde Pública, vol. 29, n. 5, p. 403-14, 1995.

PAIM, G. Industrialização e economia natural. Rio de Janeiro: Iseb, 1957 . 
PEEIFER FILHO, A. Agricultura e o ajuste do setor externo: Brasil - décadas de 70 e 80. Piracicaba, 1990. 116 p. Tese (Mestrado) - Escola Superior de Agricultura Luiz de Queiroz da Universidade de São Paulo.

PINAZZA, L. A. Aspectos do agribusiness no Brasil. Conjuntura Econômica, v. 40, n. 11, nov. 1986.

PINAZZA, L. A \& ARAÚJO, N. B. Agricultura brasileira no século XX: uma visão de agribusiness. Rio de Janeiro: Globo, 1993. $130 \mathrm{p}$.

PINHO, D. B. Manual de Economia. São Paulo: Saraiva, 1988. $443 \mathrm{p}$.

RAMALHO, Y. M. M. et al. Mudanças estruturais nas atividades agrárias: uma análise das relações intersetoriais no complexo agroindustrial brasileiro. Rio de Janeiro: BNDES/DEEST, 1988 .

RASMUSSEN, P. Studies in intersectoral relations. Amsterdam: North Holland, 1956.

RESENDE, G. C. Ajuste externo e agricultura no Brasil, 1981-86. Revista Brasileira de Economia, V. 42, n. 2, p. 101-37, abr./jun. 1988 .

RIBEIRO, S. W. \& GHEVENTER, B. Consumo intermediário na agricultura. Revista Brasileira de Economia, v. 37 , n. $1, p .77-109,1983$.

SANTANA, A. C. de. A Dinâmica do complexo agroindustrial e - crescimento econômico no Brasil. Viçosa, 1994. 302 p. Tese (Doutorado) - Universidade Federal de Viçosa. SILBER, S. D. O comércio exterior brasileiro. In: ROCCA, C. A.; BRAGA, C. A. P.; CACCIAMALI, M. C.; CASTRO, N. C. de Brasil 1980: os desafios da crise econômica. São Paulo: IPE/USP, 1988 .

SILVA, J. G. da. Complexos agroindustriais e outros complexos. Revista Associação Brasileira Reforma Agrária ABRA, V. 21, n. 3, p. 5-34, 1991. 
SILVA, J. G. A industrialização e a urbanização da agricultura brasileira. São Paulo em Perspectiva, v. 7, n. 3, p. 2-10, jul./set. 1993.

SIMONSEN, R. C. Bistória econômica do Brasil (1500/1820). 6. ed. São Paulo: Companhia Editora Nacional, 1969. (Coleção brasiliana, v. 10) .

SONIS, M.; HEWINGS, G. J. D. Error and sensitivity inputoutput analysis: a new approach. In: MILLER, R. E.; POLENSKE, K. R.; ROSE, A. Z. (eds.). Frontiers of inputoutput analysis. New York: Oxford University Press, 1989.

SONIS, M.; HEWINGS, G. J. D. Hierarchies of regional substructures and their multipliers within input-output systems: Miyazawa revisited. Bitotsubashi Journal of Economics, v. 34, p. 33-44, 1993.

SONIS, M.; HEWINGS, G. J. D. Fields of influence in inputoutput systems. Urbana: University of Illinois. Regional Economics Applications Laboratory, 1994. (mimeo).

SONIS, M. et al. Linkages, key sectors, and structural change: some new perspectives. The Developing Economics, v. 33, n. 3, p. 233-269, 1995.

SORJ, B. Estado e classes sociais na agricultura brasileira. Rio de Janeiro: Zahar, 1980. 152 p.

STREETER, D. H.; SONKA, S. T.; HUDSON, M. A. Information technology, coordination, and competitiveness in the food and agribusiness sector. American Journal of Agricultural Economics, v. 73, n. 5, p. 1465-71, 1991.

SYRQUIN, M. Patterns of structural change. In: CHENERY, H.; SRINIVASAN, T. N. (eds.). Bandbook of development economics. Amsterdam: North-Holland, 1988, v. 1, p. 203-73. 
SZMRECSANYI, T. Pequena história da agricultura no Brasil. São Paulo: Contexto, 1990. 102 p. (Coleção Repensando a história).

TOLEDO, G. L.; OVALLE, I.I. Estatistica básica. 2. ed. São Paulo: Atlas, 1983.

VALENTE, E.; SILVA, J. A.; SILVA; L. F. PIB Trimestral das Lavouras - Uma proposta Metodológica. Indicadores IBGE, v. 7, n. 4, abr. 1988 .

VALENTE, E.; SILVA, J. A.; SILVA, L. F. Ensaios sobre o produto real da agropecuária. Textos para discussão, v. 1, n. 9, set. 1988 .

WEDEKIN, I. Reestruturação competitiva do agribusiness. Agroanalysis, V. 14, n. 4, dez. 1994. 


\section{APÊNDICES}




\section{APÊNDICE 1}

Compatibilização da classificação de atividades das matrizes de 1980 e 1985-90...... 193 


\section{COMPATIBILIZAÇÃO DA CLASSIFICAÇÃO DE ATIVIDADES DAS}

\section{MATRIZES DE 1980 E $1985-90$}

\begin{tabular}{|c|c|c|c|}
\hline \multicolumn{2}{|c|}{ MATRIZ 1980} & \multicolumn{2}{|c|}{ MATRIZ 1985-90 } \\
\hline $\begin{array}{l}\text { Código } \\
\text { IBGE }\end{array}$ & Descrição & $\begin{array}{l}\text { Código } \\
\text { IBGE }\end{array}$ & Descrição \\
\hline 0100 & AGROPECUARIA & 01 & AGROPECUÁRIA \\
\hline 0210 & EXTRAÇAO MINERAIS METÁLICOS & 02 & $\begin{array}{l}\text { EXTRATTVA MINERAL (EXCETO } \\
\text { COMBUSTIVEIS) }\end{array}$ \\
\hline 0220 & EXIRAÇÃO MINERAIS NÃO METÁLICOS & 02 & $\begin{array}{l}\text { EXTRATIVA MINERAL (EXCETO } \\
\text { COMBUSTIVEIS) }\end{array}$ \\
\hline 0310 & EXTRAÇĀO DE PETRÓLEO & 03 & EXTRAÇÃO DE PETRÓLEO E CARVÃO \\
\hline 0320 & EXTRAÇÃO DE CARVÃO MINERAL & 03 & EXTRAÇÃO DE PETRÓLEO E CARVÃO \\
\hline 0410 & FAB. DE CMENTO & 04 & FAB. DE MINERAIS NẢO METÁLICOS \\
\hline 0420 & FAB. DE ESTRUTURA DE CIMENTO & 04 & FAB. DE MINERAIS NÃO METÁLICOS \\
\hline 0430 & FAB. DE VIDRO & 04 & FAB. DE MINERAIS NÃO METÁLICOS \\
\hline 0440 & FAB. DE MINERAIS NÃO METALIICOS & 04 & FAB. DE MINERAIS NÃO METÁLICOS \\
\hline 0510 & SDERURGLA & 05 & SIDERURGIA \\
\hline 0610 & METALURGLA DE NÃO FERROSOS & 06 & METALURGIA DE NÃO FERROSOS \\
\hline 0710 & FUNDDDOS E FORJADOS DE AÇO & 07 & $\begin{array}{l}\text { FAB. DE OUTROS PRODUTOS } \\
\text { METALÚRGICOS }\end{array}$ \\
\hline 0720 & FAB. DE OUTROS METALURGICOS & 07 & $\begin{array}{l}\text { FAB. DE OUTROS PRODUTOS } \\
\text { METALÚRGICOS }\end{array}$ \\
\hline 0810 & FAB. DE MAQUINAS RNCLUSIVE PEÇAS & 08 & $\begin{array}{l}\text { FAB. E MANUIENÇÃO DE MÁQUINAS E } \\
\text { TRATORES }\end{array}$ \\
\hline 0820 & $\begin{array}{l}\text { FAB. TRATORES E MAQUUNAS } \\
\text { RODOVIARIAS }\end{array}$ & 08 & $\begin{array}{l}\text { FAB. E MANUTENÇÃO DE MÁQUINAS E } \\
\text { TRATORES }\end{array}$ \\
\hline 0910 & $\begin{array}{l}\text { MANUTENÇÃO E REPARAÇÃO DE } \\
\text { MÁQUINAS }\end{array}$ & 08 & $\begin{array}{l}\text { FAB. E MANUTENÇÃO DE MÁQUINAS E } \\
\text { TRATORES }\end{array}$ \\
\hline 1010 & FAB. DE EQUTPAM DE ENERGIA ELETRICA & 10 & FAB. DE MATERIAL ELÉTRICO \\
\hline 1020 & FAB. DE MATERIAL ELEIRICO & 10 & FAB. DE MATERIAL ELÉTRICO \\
\hline 1030 & $\begin{array}{l}\text { FAB. DE APARELHOS } \\
\text { ELETRODOMÉSTICOS }\end{array}$ & 10 & FAB. DE MATERIAL ELÉTRICO \\
\hline 1110 & FAB. DE APARELHOS ELETRÔNICOS & 11 & FAB. DE EQUIPAMENTOS ELETRÔNICOS \\
\hline 1120 & FAB. DE TV. RÁDIO E SOM & 11 & FAB. DE EQUIPAMENTOS ELETRÔNICOS \\
\hline 1210 & $\begin{array}{l}\text { FAB. AUTOMÓVEIS, CAMINHỎES E } \\
\text { ONIBUS }\end{array}$ & 12 & $\begin{array}{l}\text { FAB. DE AUTOMÓVEIS, CAMINHŌES E } \\
\text { ÔNIBUS }\end{array}$ \\
\hline 1310 & FAB. DE PECAS E OUTROS VEICULOS & 13 & FAB. DE PEÇAS E OUTROS VEICULOS \\
\hline 1320 & INDÚSTRIA NAVAL & 13 & FAB. DE PEÇAS E OUTROS VEICULOS \\
\hline 1330 & FAB. DE VEICULOS FERROVIÁRIOS & 13 & FAB. DE PEÇAS E OUTROS VEICULOS \\
\hline 1340 & FAB. DE OUTROS VEICULOS & 13 & FAB. DE PEÇAS E OUTROS VEICULOS \\
\hline 1410 & INDÚSTRIA DA MADEIRA & 14 & MADEIRA E MOBLIÁRIO \\
\hline 1420 & INDÚSTRIA DO MOBLIÁRIO & 14 & MADEIRA E MOBILLÁRIO \\
\hline 1510 & FAB. DE CELULOSE & 15 & CELULOSE, PAPEL E GRÁFICA \\
\hline 1520 & FAB. DE PAPEL E ARTEFATOS & 15 & CELULOSE, PAPEL E GRÁFICA \\
\hline 1530 & EDTIORIAL E GRÁFICA & 15 & CELULOSE, PAPEL E GRÁFICA \\
\hline 1610 & INDÚSTRIA DA BORRACHA & 16 & INDÚSTRIA DA BORRACHA \\
\hline 1710 & FAB. DE ELEMENTOS QUTMICOS & 17 & FAB. ELEMENTOS QUUMMICOS \\
\hline 1720 & DESTILAÇÃO DO ÁLCOOL & 17 & FAB. ELEMENTOS QUIMICOS \\
\hline
\end{tabular}




\section{COMPATIBILIZAC̣ÃO DA CLASSIFICAÇÃO DE ATIVIDADES DAS}

MATRIZES DE 1980 E $1985-90$

\begin{tabular}{|c|c|c|c|}
\hline $\begin{array}{l}\text { MATRI } \\
\text { Código } \\
\text { IBGE } \\
\end{array}$ & $\begin{array}{l}\text { Z } 1980 \\
\text { Descrição }\end{array}$ & $\begin{array}{c}\text { MATRIZ } \\
\text { Código } \\
\text { IBGE }\end{array}$ & $\begin{array}{l}\text { 1985-90 } \\
\text { Descrição }\end{array}$ \\
\hline 1810 & REFINO DO PETROEEO & 18 & REFINO DO PETRÓLEO \\
\hline 1820 & PEIROQUTMCA & 18 & REFINO DO PETRÓLEO \\
\hline 1830 & FAB. DE RESNAS E FIBRAS & 18 & REFINO DO PETRÓLEO \\
\hline 1910 & FAB DE ADUBOS E FERTLZANTES & 19 & FAB. DE PRODUTOS QUTMICOS DIVERSOS \\
\hline 1920 & FAB DE PRODUTOS QUIMICOS DIVERSOS & 19 & FAB. DE PRODUTOS QUIMICOS DIVERSOS \\
\hline 2010 & INDUSTRIA FARMACĖUTICA & 20 & $\begin{array}{l}\text { NDUUSTRIA FARMACÊUTICA E DE } \\
\text { PERFUMARIA }\end{array}$ \\
\hline 2020 & NDUSTRLA DE PERFUMARIA & 20 & $\begin{array}{l}\text { INDUUSTRIA FARMACÊUTICA E DE } \\
\text { PERFUMARIA }\end{array}$ \\
\hline 2110 & FAB. DE LALINADOS PLÁSTICOS & 21 & INDÚSTRIA DE ARTIGOS DE PLÁSTICO \\
\hline 2120 & FA. DE ARTGOS DE PLASTICO & 21 & INDÚSTRIA DE ARTIGOS DE PLÁSTICO \\
\hline 2210 & FIACAAO DE TECIDOS E FIBRAS NATURAIS & 22 & INDÚSTRIA TEXTL \\
\hline 2220 & $\begin{array}{l}\text { FIACAO TECIDOS E FIRRAS ART. E } \\
\text { SNTETCAS }\end{array}$ & 22 & INDÚSTRIA TĖXTL \\
\hline 2230 & OUTRAS INDUSTRIAS TEXXTEIS & 22 & INDÚSTRIA TÊXTL \\
\hline 2310 & FAB. DE ARTIGOS DO VESTUARIO & 23 & FAB. DE ARTIGOS DO VESTUÁRIO \\
\hline 2410 & NDUSTRLA DE COUROS E PELES & 24 & FAB. DE CALÇADOS \\
\hline 2420 & FAB DE CALCADOS & 24 & FAB. DE CALCADOS \\
\hline 2510 & NUSTRIA DO CAFE & 25 & INDÚSTRIA DO CAFÉ \\
\hline 2610 & BENEFICLAMENTO DE ARROZ & 26 & $\begin{array}{l}\text { BENEFICIAMENTO DE PRODUTOS } \\
\text { VEGETAIS }\end{array}$ \\
\hline 2620 & MOAGEM DE TRIGO & 26 & $\begin{array}{l}\text { BENEFICLAMENTO DE PRODUTOS } \\
\text { VEGETAIS }\end{array}$ \\
\hline 2630 & PREPARACAAO DE CONSERVAS E SUCOS & 26 & $\begin{array}{l}\text { BENEFICLAMENTO DE PRODUTOS } \\
\text { VEGETAIS }\end{array}$ \\
\hline 2640 & $\begin{array}{l}\text { BENEFCLIAMENTO DE PRODUTOS } \\
\text { VEGETAIS }\end{array}$ & 26 & $\begin{array}{l}\text { BENEFICIAMENTO DE PRODUTOS } \\
\text { VEGETAIS }\end{array}$ \\
\hline 2650 & NDÜSTRIA DO FUMO & 26 & $\begin{array}{l}\text { BENEFICIAMENTO DE PRODUTOS } \\
\text { VEGETAIS }\end{array}$ \\
\hline 2710 & ABATE E PREPARAÇÃO DE CARNE & 27 & ABATE DE ANIMAIS \\
\hline 2720 & ABATE E PREPARAÇÃO DE AVES & 27 & ABATE DE ANIMAIS \\
\hline 2810 & NDUUSTRIA DE LATICINIOS & 28 & INDÚSTRIA DE LATICÍNIOS \\
\hline 2910 & DNUUSTRIA DO AÇUC.AR & 29 & FAB. DE AÇÚCAR \\
\hline 3010 & FAB. OLLEOS VEGETAIS EM BRUTO & 30 & FAB. DE ÓLEOS VEGETAIS \\
\hline 3020 & REFINO DE OLLEOS VEGETAIS & 30 & FAB. DE ÓLEOS VEGETAIS \\
\hline 3110 & FAB. DE RAÇỎES & 31 & $\begin{array}{l}\text { FAB. DE OUTROS PRODUTOS } \\
\text { ALIMENTARES }\end{array}$ \\
\hline 3120 & OUTRAS INDÚSTRIAS ALIMENTARES & 31 & $\begin{array}{l}\text { FAB. DE OUTROS PRODUTOS } \\
\text { ALIMENTARES }\end{array}$ \\
\hline 3130 & NDÜSTRIA DE BEBIDAS & 31 & $\begin{array}{l}\text { FAB. DE OUTROS PRODUTOS } \\
\text { ALIMENTARES }\end{array}$ \\
\hline
\end{tabular}


COMPATIBILIZAÇÃO DA CLASSIFICAÇÃO DE ATIVIDADES DAS

MATRIZES DE 1980 E $1985-90$

\begin{tabular}{|c|c|c|c|}
\hline \multicolumn{2}{|c|}{ MATRIZ 1980} & \multicolumn{2}{|c|}{ MATRIZ 1985-90 } \\
\hline $\begin{array}{l}\text { Código } \\
\text { IBGE }\end{array}$ & Descrição & $\begin{array}{l}\text { Código } \\
\text { IBGE }\end{array}$ & Descrição \\
\hline 3210 & FAB. DE PRODUTOS DIVERSOS & 32 & INDÚSTRIAS DIVERSAS \\
\hline 3310 & ENERGIA ELÉTRICA & 33 & $\begin{array}{l}\text { SERVIÇOS INDUSTRIAIS DE UTLIDADE } \\
\text { PÚBLICA }\end{array}$ \\
\hline 3320 & UTLIDADE PÚBLICA & 33 & $\begin{array}{l}\text { SERVICCOS INDUSTRIAIS DE UTILDADE } \\
\text { PÚBLICA }\end{array}$ \\
\hline 3410 & CONSTRUÇÃO CIVIL & 34 & CONSTRUÇÃO CIVL \\
\hline 3510 & COMÉRCIO & 35 & COMÉRCIO \\
\hline 3610 & TRANSPORTE RODOVIÁRIO & 36 & TRANSPORTE \\
\hline 3620 & TRANSPORTE FERROVIÁRIO & 36 & TRANSPORTE \\
\hline 3630 & TRANSPORTE HERROVIARIO & 36 & TRANSPORTE \\
\hline 3640 & TRANSPORTE AEREO & 36 & TRANSPORTE \\
\hline 3710 & COMUNICAÇÕES & 37 & COMUNICAÇÕES \\
\hline 3810 & INSTTTUÇÕES DE SEGUROS & 38 & INSTITUIÇÕES FINANCEIRAS \\
\hline 3820 & INSTTTUIÇÕES FINANCEIRAS & 38 & INSTITUIÇOEES FINANCEIRAS \\
\hline \multirow[t]{2}{*}{3910} & SERVIÇO DE ALOJAMENTO E & 39 & SERVIÇOS PRESTADOS ȦS FAMILIAS \\
\hline & ALIMENTAÇĀO & & \\
\hline 3920 & SERVIÇO DE REPARAÇÕES & 39 & SERVIÇOS PRESTADOS ȦS FAMULIAS \\
\hline 3930 & SERVIÇOS PRESTADOS ÀS FAMÍLIAS & 39 & SERVIÇOS PRESTADOS ÀS FAMILIAS \\
\hline 3940 & SAÚDE MERCANTIL & 39 & SERVIÇOS PRESTADOS ÀS FAMILIAS \\
\hline 3950 & EDUCAÇÃO MERCANTIL & 39 & SERVIÇOS PRESTADOS AS FAMILIAS \\
\hline 4010 & SERVIÇOS PRESTADOS ÀS EMPRESAS & 40 & SERVIÇOS PRESTADOS AS EMPRESAS \\
\hline 4020 & ALUGUEL DE BENS MÓVEIS & 40 & SERVIÇOS PRESTADOS ÀS EMPRESAS \\
\hline 4110 & ALUGUEL MMÓVEIS & 41 & ALUGUEL DE IMÓVEIS \\
\hline 4210 & ADMINISTRAÇÃO PÚBLICA & 42 & ADMINISTRAÇĀO PÚBLICA \\
\hline 4220 & SAÚDE PÚBLICA & 42 & ADMINISTRAÇÃO PÚBLICA \\
\hline 4230 & EDUCAÇÃO PÚBLICA & 42 & ADMINISTRAÇÃO PÚBLICA \\
\hline 4310 & SERVIÇOS PRIVADOS NÃO MERCANTIS & 43 & SERVIÇOS PRIVADOS NÃO MERCANTIS \\
\hline 4610 & DUMMY FINANCEIRO & 46 & DUMMY FINANCEIRO \\
\hline
\end{tabular}


COMPATIBILIZAÇÃO DA CLASSIFICAÇÃO DE PRODUTOS DAS

MATRIZES DE 1980 E 1985-90

\begin{tabular}{|c|c|c|c|}
\hline \multicolumn{2}{|c|}{ MATRIZ 1980} & \multicolumn{2}{|c|}{ MATRIZ 1985-90 } \\
\hline $\begin{array}{l}\text { Código } \\
\text { IBGE }\end{array}$ & Descriçāo & $\begin{array}{c}\text { Código } \\
\text { IBGE }\end{array}$ & Descrição \\
\hline 01001 & MADEIRA & 0199 & OUTROS PRODUTOS AGROPECUÁRIOS \\
\hline 01002 & CARVAOO E LENHA & 0199 & OUTROS PRODUTOS AGROPECUÁRIOS \\
\hline 01003 & EXTRATTVA VEGETAL & 0199 & OUTROS PRODUTOS AGROPECUÁRIOS \\
\hline 01004 & CAFE & 0101 & CAFÉ EM COCO \\
\hline 01005 & CANA-DE-AÇU்CAR & 0102 & CANA-DE-AÇÚCAR \\
\hline 01006 & ARROZ & 0103 & ARROZ EM CASCA \\
\hline 01007 & TRIGO & 0104 & TRIGO EM GRÃO \\
\hline 01008 & SOJA & 0105 & SOJA EM GRĀO \\
\hline 01009 & ALGODÃO & 0106 & ALGODÃO EM CAROÇO \\
\hline 01010 & FUMO & 0199 & OUTROS PRODUTOS AGROPECUẢRIOS \\
\hline 01011 & MIIHO & 0107 & MIIHO EM GRÃO \\
\hline 01012 & OUTROS AGRICOLAS & 0199 & OUTROS PRODUTOS AGROPECUARIOS \\
\hline 01013 & REFLORESTAMENIO & 0199 & OUTROS PRODUTOS AGROPECUÁRIOS \\
\hline 01014 & AVES & 0110 & AVES VIVAS \\
\hline 01015 & BOVINOS E SUTNOS & 0108 & BOVINOS E SUINOS \\
\hline 01016 & LETIE & 0109 & LEITE NATURAL \\
\hline 01017 & PRODUTOS ANIMAIS & 0199 & OUIROS PRODUTOS AGROPECUÁRIOS \\
\hline 02101 & MINERIO DE FERRO & 0201 & MINÉRIO DE FERRO \\
\hline 02102 & MINERAIS METÁLICOS & 0202 & OUTROS MINERAIS \\
\hline 02201 & MINERAIS NÃO METÁLICOS & 0202 & OUTROS MINERAIS \\
\hline 03101 & PETRÓLEOE GÁS & 0301 & PETRÓLEO E GÁS \\
\hline 03201 & CARVÃO MINERAL & 0302 & CARVÃO E OUTROS \\
\hline 04101 & CIMENTO & 0401 & PRODUTOS MINERAIS NĀO METÁLICOS \\
\hline 04201 & ARTIGOS DE CIMENTO & 0401 & PRODUTOS MINERAIS NÃO METÁLICOS \\
\hline 04301 & VIDRO & 0401 & PRODUTOS MINERAIS NÃO METÁLICOS \\
\hline 04302 & ARTIGOS DE VIDRO & 0401 & PRODUTOS MINERAIS NÃO METÁLICOS \\
\hline 04401 & PRODUTOS NÃO METÁLICOS & 0401 & PRODUTOS MINERAIS NÃO METÁLICOS \\
\hline 05101 & SDERÚRGICOS BÁSICOS & 0501 & PRODUTOS SIDERÚRGICOS BÁSICOS \\
\hline 05102 & COQUE & 0501 & PRODUTOS SIDERÚRGICOS BÁSICOS \\
\hline 05103 & LAMINADOS DE AÇO & 0502 & LAMINADOS DE ACCO \\
\hline 06101 & METALUURGICOS NĀO FERROSOS & 0601 & PROD. METALÚRGICOS NÃO FERROSOS \\
\hline 07101 & FUNDIDOS DE AÇO & 0701 & OUTROS PRODUTOS METALÚRGICOS \\
\hline 07201 & OUTROS METALÚRGICOS & 0701 & OUTROS PRODUTOS METALÚRGICOS \\
\hline 07202 & SERVIÇOS METALÚRGICOS & 0701 & OUTROS PRODUTOS METALÚRGICOS \\
\hline 08101 & MÁQUINAS INDUSTRIAIS & 0801 & FAB. E MANUT. DE MÁQ./EQUIPAMENTOS \\
\hline 08102 & MAQUUINAS NÃO INDUSTRIAIS & 0801 & FAB. E MANUT. DE MÁQ./EQUIPAMENTOS \\
\hline 08103 & PEÇAS PARA MÁQUINAS & 0801 & FAB. E MANUT. DE MÁQ.EQUUPAMENTOS \\
\hline 08201 & TRATORES & 0802 & TRATORES E MÁQ. DE TERRAPLANAGEM \\
\hline 09101 & MANUTENÇÃO DE MAQUUNAS & 0801 & FAB. E MANUT. DE MÁQ./EQUIPAMENTOS \\
\hline 10101 & EQUIPAM. P/ENERGIA ELÉTRICA & 1001 & MATERIAL ELÉTRICO \\
\hline 10201 & CONDUTORES ELÉTRICOS & 1001 & MATERIAL ELÉTRICO \\
\hline 10202 & MATERIAL ELETRICO & 1001 & MATERIAL ELÉTRICO \\
\hline 10301 & ELEIRODOMESTTICOS & 1001 & MATERIAL ELÉTRICO \\
\hline
\end{tabular}


COMPATIBILIZAÇÃo dA CLASSIFICAÇÃO dE PRODUTOS dAS

MATRIZES DE 1980 E 1985-90

\begin{tabular}{|c|c|c|c|}
\hline \multicolumn{2}{|c|}{ MATRIZ 1980} & \multicolumn{2}{|c|}{ MATRIZ 1985-90 } \\
\hline $\begin{array}{c}\text { Código } \\
\text { IBGE }\end{array}$ & Descrição & $\begin{array}{l}\text { Código } \\
\text { IBGE }\end{array}$ & Descrição \\
\hline 10302 & APARELHOS ELEIRICOS & 1001 & MATERIAL ELÉTRICO \\
\hline 11101 & EIETRÔNICOS & 1101 & EQUIPAMENTOS ELETRÔNICOS \\
\hline 11102 & EQUIPAMENTOS ELEIRȮNICOS & 1101 & EQUIPAMENTOS ELETRÔNICOS \\
\hline 11201 & RADIO, TV & 1101 & EQUIPAMENTOS ELETRÔNICOS \\
\hline 12101 & AUTOMOVEIS E CAMINHOESS & 1201 & AUTOMÓVEIS, CAMINHÕES E ÔNIBUS \\
\hline 13101 & PECAS PARA VEICULOS & 1301 & OUTROS VEICULOS E PECAS \\
\hline 13201 & EMRARCAÇŌES & 1301 & OUTROS VEICULOS E PECAS \\
\hline 13202 & REPARAÇÃO NAVAL & 1301 & OUTROS VEICULOS E PEÇAS \\
\hline 13301 & VEICULOS FERROVIARIOS & 1301 & OUTROS VEICULOS E PEÇAS \\
\hline 13302 & REPARAÇĀO VEICULOS FERROV. & 1301 & OUTROS VEICULOS E PEÇAS \\
\hline 13401 & OUTROS VEICULOS & 1301 & OUTROS VEICULOS E PEÇAS \\
\hline 14101 & PRODUTOS DA MADEIRA & 1401 & MADERA E MOBILIARIO \\
\hline 14201 & MOBLIARIO & 1401 & MADEIRA E MOBILÁRIO \\
\hline 15101 & CELULOSE & 1501 & PAPEL, CELULOSE, PAPELÃO E ARTEF. \\
\hline 15201 & PAPEL & 1501 & PAPEL, CELULOSE, PAPELÃO E ARTEF. \\
\hline 15301 & PRODUTOS GRAFICOS & 1501 & PAPEL, CELULOSE, PAPELÃO E ARTEF. \\
\hline 15302 & SERVIÇOS GRÁFICOS & 1501 & PAPEL, CELULOSE, PAPELÃO E ARTEF. \\
\hline 16101 & PNEUS & 1601 & PRODUTOS DERIVADOS DA BORRACHA \\
\hline 16102 & PRODUTOS DA BORRACHA & 1601 & PRODUTOS DERIVADOS DA BORRACHA \\
\hline 17101 & ELEMENTOS QUIMICOS & 1701 & ELEM QUIMICOS NÃO PETROQUIMICOS \\
\hline 17201 & ALCOOL & 1702 & ÁLCOOL DE CANA E DE CEREAIS \\
\hline 18101 & GASOLINA & 1801 & GASOLINA PURA \\
\hline 18102 & OLEO COMBUSTIVEL & 1802 & ÓLEOS COMBUSTIVEIS E ÓLEO DIESEL \\
\hline 18103 & OUTROS PRODUTOS DO REFTNO & 1803 & OUTROS PRODUTOS DO REFINO \\
\hline 18104 & GASOALCOOL & 1806 & GASOÁLCOOL \\
\hline 18201 & PETROQUTMICOS BÁSICOS & 1804 & PRODUTOS PETROQUIMICOS BÁSICOS \\
\hline 18202 & PETROQUIMICOS INIERMEDIARIOS & 1804 & PRODUTOS PETROQUIMICOS BÁSICOS \\
\hline 18301 & RESINAS & 1805 & RESINAS \\
\hline 19101 & ADUBOS & 1901 & ADUBOS \\
\hline 19201 & TINTAS & 1902 & TINTAS \\
\hline 19202 & OUTROS QUTMICOS & 1903 & OUIROS PRODUTOS QUMMCOS \\
\hline 20101 & FARMACËUTICOS NẢO-DOSADOS & 2001 & PROD. FARMACÊUTICOS E PERFUMARIA \\
\hline 20102 & FARMACÊUTICOS DOSADOS & 2001 & PROD. FARMACÊUTICOS E PERFUMARIA \\
\hline 20201 & PERFUMARIA & 2001 & PROD. FARMACÊUTICOS E PERFUMARIA \\
\hline 21101 & LAMINADOS PLÁSTICOS & 2101 & ARTIGOS DE PLÁSTTCO \\
\hline 21201 & ARTIGOS DE PLASTIICOS & 2101 & ARTIGOS DE PLÁSTICO \\
\hline 22101 & FIOS NATURAIS & 2201 & FIOS TEXTEIS NATURAIS \\
\hline 22102 & TECIDOS NATURAIS & 2202 & TECDOS NATURAIS \\
\hline 22201 & FIOS ARTIFICLAIS & 2203 & FIOS TÊXTEIS ARTIFICIAIS \\
\hline 22202 & TECDOS ARTIFICIAIS & 2204 & TECIDOS ARTIFICIAIS \\
\hline
\end{tabular}




\section{COMPATIBILIZAÇÃO DA CLASSIFICAÇÃO DE PRODUTOS DAS}

MATRIZES DE 1980 E $1985-90$

\begin{tabular}{|c|c|c|c|}
\hline \multicolumn{2}{|c|}{ MATRIZ 1980} & \multicolumn{2}{|c|}{ MATRIZ 1985-90 } \\
\hline $\begin{array}{l}\text { Código } \\
\text { IBGE }\end{array}$ & Descrição & $\begin{array}{l}\text { Código } \\
\text { IBGE }\end{array}$ & Descrição \\
\hline 22301 & OUTROS TEXXTESIS & 2205 & OUTROS PRODUTOS TÊXTEIS \\
\hline 23101 & ARTIGOS DO VESTUARIO & 2301 & ARTIGOS DO VESTUÁRIO \\
\hline 24101 & PRODUTOS DO COURO & 2401 & PRODUTOS DE COURO E CALÇADOS \\
\hline 24201 & CALCADOS & 2401 & PRODUTOS DE COURO E CALÇADOS \\
\hline 25101 & CAFE & 2501 & PRODUTOS DOCAFÉ \\
\hline 26101 & ARROZ & 2601 & ARROZ BENEFICIADO \\
\hline 26201 & RRGO & 2602 & FARINHA DE TRIGO \\
\hline 26301 & SLCOS E CONSERVAS & 2603 & OUTROS PROD. VEGETAIS BENEFICIADOS \\
\hline 26401 & VEGETAIS BENEFICIADOS & 2603 & OUTROS PROD. VEGETAIS BENEFICLADOS \\
\hline 26501 & PRODUTOS DO FUMO & 2603 & OUTROS PROD. VEGETAIS BENEFICIADOS \\
\hline 27101 & CARNES & 2701 & CARNE BOVINA \\
\hline 27102 & OUTROS DO ABATE & 2701 & CARNE BOVINA \\
\hline 27201 & AVES ABATDAS & 2702 & CARNE DE AVES ABATIDAS \\
\hline 28101 & LETE BENEFICIADO & 2801 & LEITE BENEFICIADO \\
\hline 28102 & LATICINIOS & 2802 & OUTROS LATICINIOS \\
\hline 29101 & AÇUCAR & 2901 & AÇUCAR \\
\hline 30101 & OLEOS VEGETAIS EM BRUTO & 3001 & ÓLEOS VEGETAIS EM BRUTO \\
\hline 30102 & TORTAS E FARELOS & 3001 & ÓLEOS VEGETAIS EM BRUTO \\
\hline 30201 & OLEOS REFNADOS & 3002 & ÓLEOS VEGETAIS REFINADOS \\
\hline 31101 & RAÇÓES & 3101 & RAÇŐES E OUTROS PROD. ALIMENTARES \\
\hline 31201 & OUTROS ALMENTARES & 3101 & RAÇÕES E OUTROS PROD. ALIMENTARES \\
\hline 31301 & BEBIDAS & 3102 & BEBIDAS \\
\hline 32101 & PRODUTOS DIVERSOS & 3201 & PRODUTOS DIVERSOS \\
\hline 32901 & SUCATA & 3201 & PRODUTOS DIVERSOS \\
\hline 32902 & SERVIÇOS RDUSTRLAIS & 3201 & PRODUTOS DIVERSOS \\
\hline 32903 & RESIDUOS & 3201 & PRODUTOS DIVERSOS \\
\hline 33101 & ENERGLA ELETRICA & 3301 & SERV. INDUSTRIAIS UTLIDADE PÚBLICA \\
\hline 33201 & AGUA E ESGOTO & 3301 & SERV. INDUSTRIAIS UTILIDADE PÚBLICA \\
\hline 34101 & PRODUTOS DA CONSTRUÇÃO CIVIL & 3401 & PRODUTOS DA CONSTRUÇÃO CIVIL \\
\hline 35101 & MARGEM DE COMERCIO & 3501 & MARGEM DE COMÉRCIO \\
\hline 36101 & TRANSPORRTE RODOVIÁRIO & 3601 & MARGEM DE TRANSPORTE \\
\hline 36201 & IRANSPORTE FERROVIARIO & 3601 & MARGEM DE TRANSPORTE \\
\hline 36301 & IRANSPORTE HIDROVIARIO & 3601 & MARGEM DE TRANSPORTE \\
\hline 36401 & TRANSPORTE AEREO & 3601 & MARGEM DE TRANSPORTE \\
\hline 37101 & COMUNICAÇOESS & 3701 & COMUNICAÇÕES \\
\hline 38101 & SEGUROS & 3801 & SEGUROS \\
\hline 38201 & SERVIÇOS FINANCEIROS & 3802 & SERVIÇOS FINANCEIROS \\
\hline 39101 & ALOJAMENTO E ALIMENTAÇÃO & 3901 & ALOJAMENTO E ALIMENTAÇÃO \\
\hline 39201 & SERVIÇOS DE REPARAÇÃO & 3902 & OUTROS SERVIÇOS \\
\hline 39301 & SERVIÇOS PRESTADOS ÀS FAMTIIAS & 3902 & OUTROS SERVIÇOS \\
\hline 39401 & SAUUDE MERCANTIL & 3903 & SAÚDE E EDUCAÇÃO MERCANTIS \\
\hline
\end{tabular}




\section{COMPATIBILIZAÇÃO DA CLASSIFICAÇÃO DE PRODUTOS DAS}

MATRIZES DE 1980 E $1985-90$

\begin{tabular}{|c|c|c|c|}
\hline \multicolumn{2}{|c|}{ MATRIZ 1980} & \multicolumn{2}{|c|}{ MATRIZ 1985-90 } \\
\hline $\begin{array}{c}\text { Código } \\
\text { IBGE }\end{array}$ & Descrição & $\begin{array}{c}\text { Código } \\
\text { IBGE }\end{array}$ & Descrição \\
\hline 39501 & EDUCAÇȦO MERCANIIL & 3903 & SAÚDE E EDUCAÇÃO MERCANITS \\
\hline 40101 & PUBIICIDADE E PROPAGANDA & 4001 & SERVIÇOS PRESTADOS ÀS EMPRESAS \\
\hline 40102 & SERVIÇOS PRESTADOS AS EMPRESAS & 4001 & SERVIÇOS PRESTADOS ÀS EMPRESAS \\
\hline 40201 & ALUGUEL DE BENS MÓVEIS & 4001 & SERVIÇOS PRESTADOS ÀS EMPRESAS \\
\hline 41101 & ALUGUEI MMÓVEIS & 4001 & ALUGUEL DE IMÓVEIS \\
\hline 41102 & ALUGUEL MPUTADO & 4102 & ALUGUEL IMPUTADO \\
\hline 42101 & ADAINISTRAÇÃO PÚBLICA & 4201 & ADMINISTRAÇÃO PÚBLICA \\
\hline 42201 & SAÜDE PUBBLICA & 4202 & SAÚDE PÚBLICA \\
\hline 42301 & EDUCAÇÃO PÜBLICA. & 4203 & EDUCAÇÃO PÚBLICA \\
\hline 43101 & SERVIÇOS NÄO MERCANTIS & 4301 & SERVIÇOS PRIVADOS NÃO MERCANTIS \\
\hline 43102 & SERVIÇOS DOMESTICOS & 4301 & SERVIÇOS PRIVADOS NÃO MERCANTIS \\
\hline 99999 & AUUSTE EXTRA TERRTORIAL & 9999 & AUUSTE EXTRA TERRITORIAL \\
\hline
\end{tabular}




\section{APÊNDICE 2}

A 2.1. Estimativas em valores correntes da Matriz AGR - $1980 \ldots \ldots \ldots \ldots \ldots \ldots \ldots \ldots \ldots \ldots . . . . . . . . . . . . .201$

A 2.2. Estimativas em valores correntes da Matriz AGR - 1985........................... 207

A 2.3. Estimativas em valores correntes da Matriz AGR - $1990 \ldots \ldots \ldots \ldots \ldots \ldots \ldots \ldots \ldots \ldots \ldots . . .213$ 


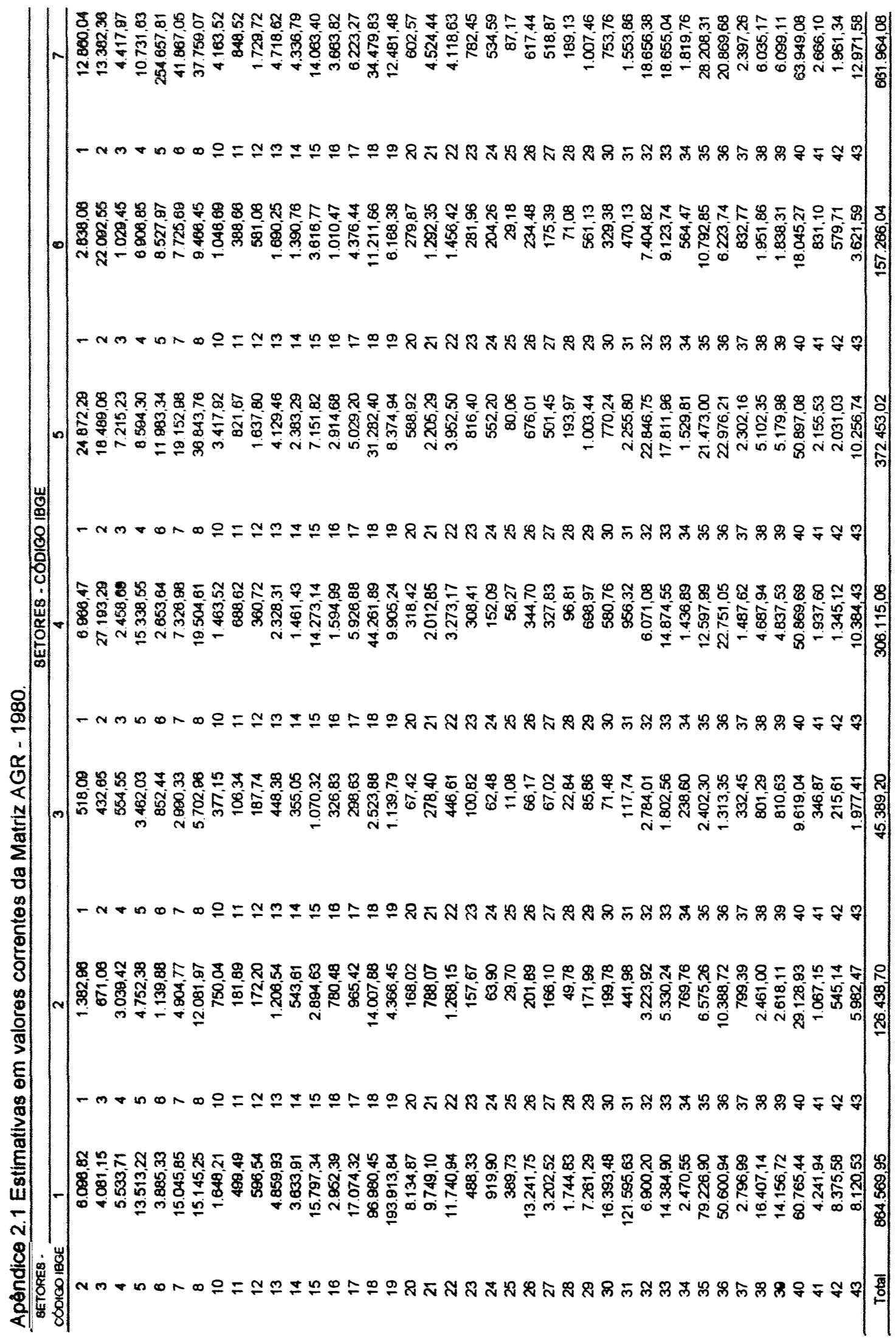




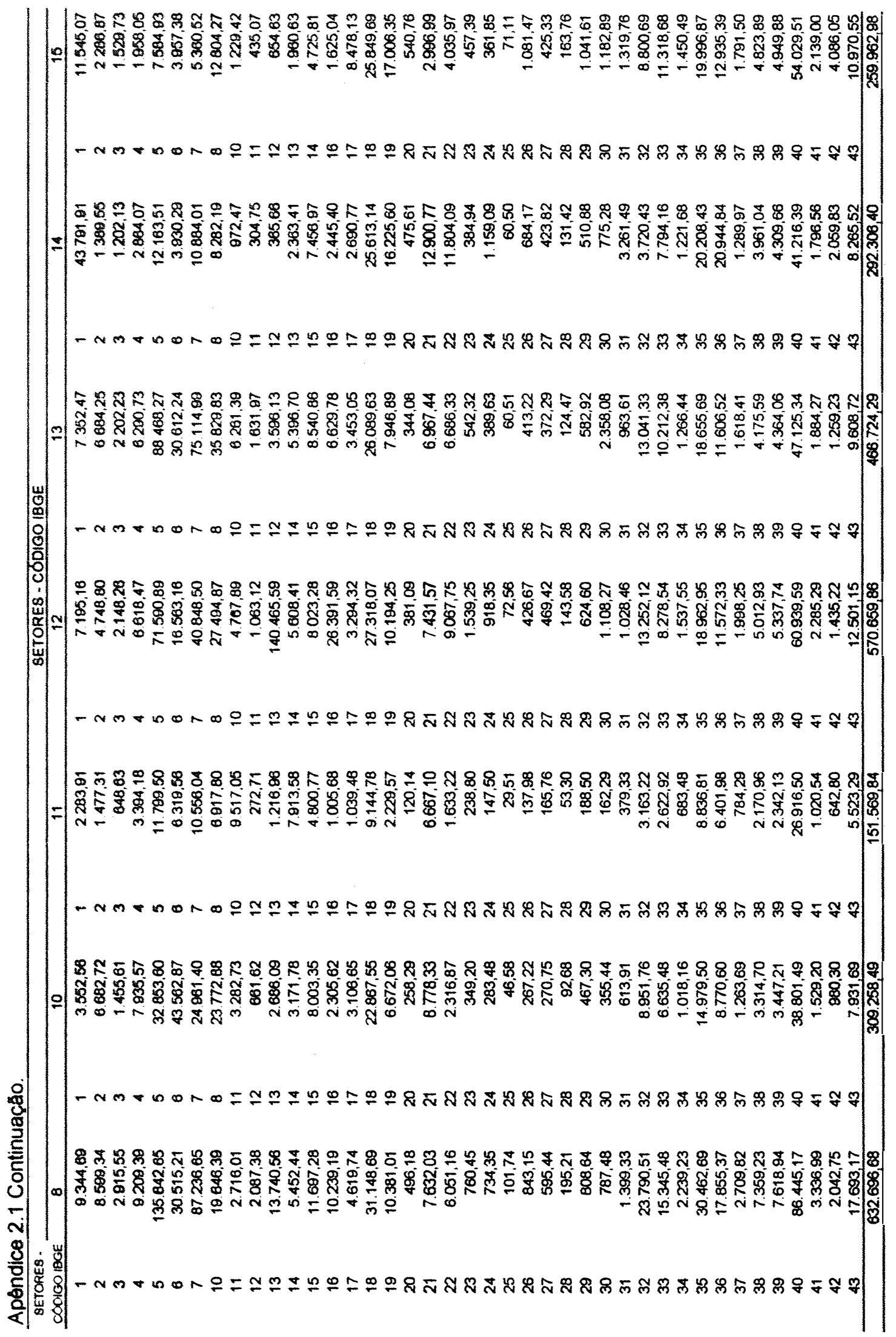




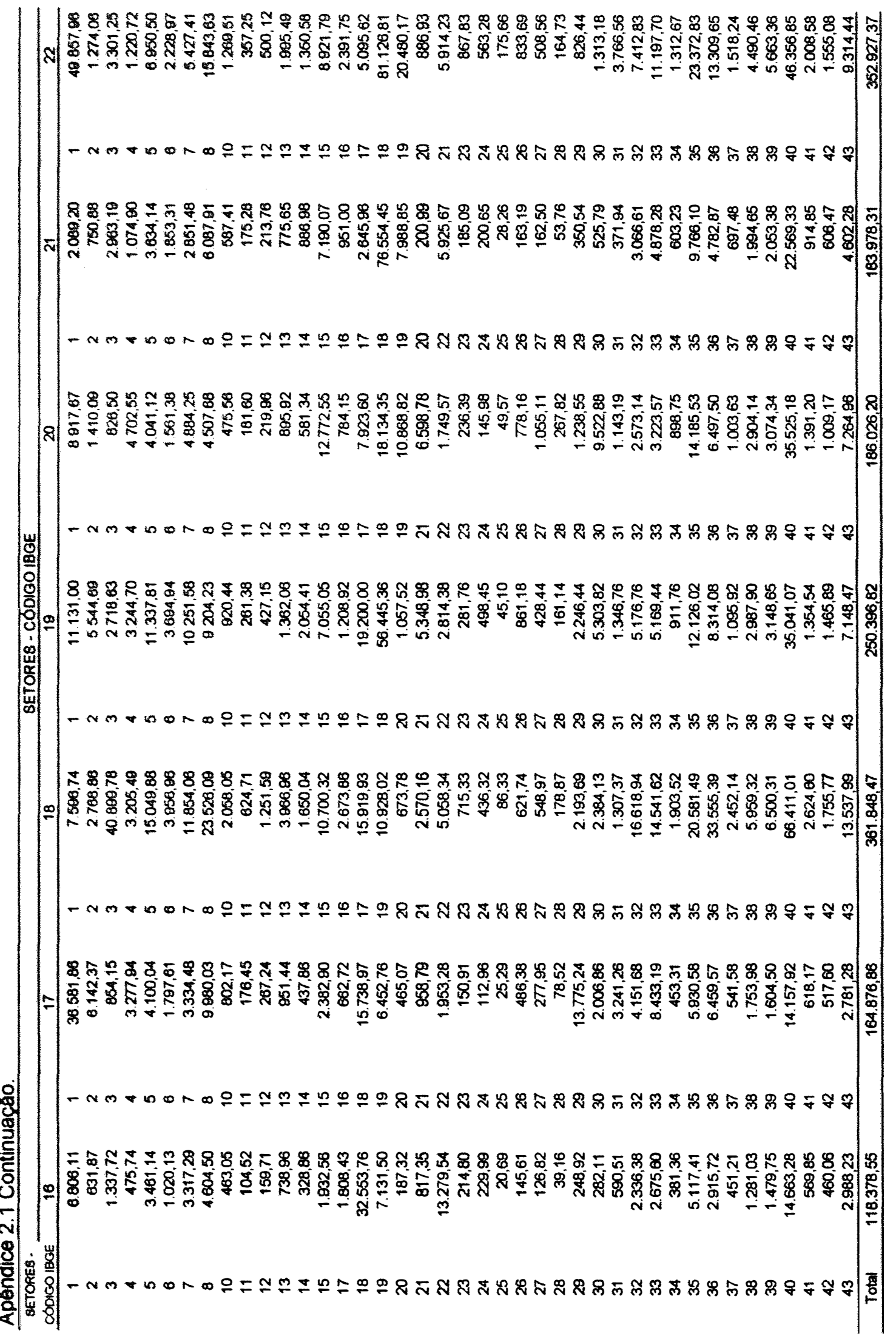




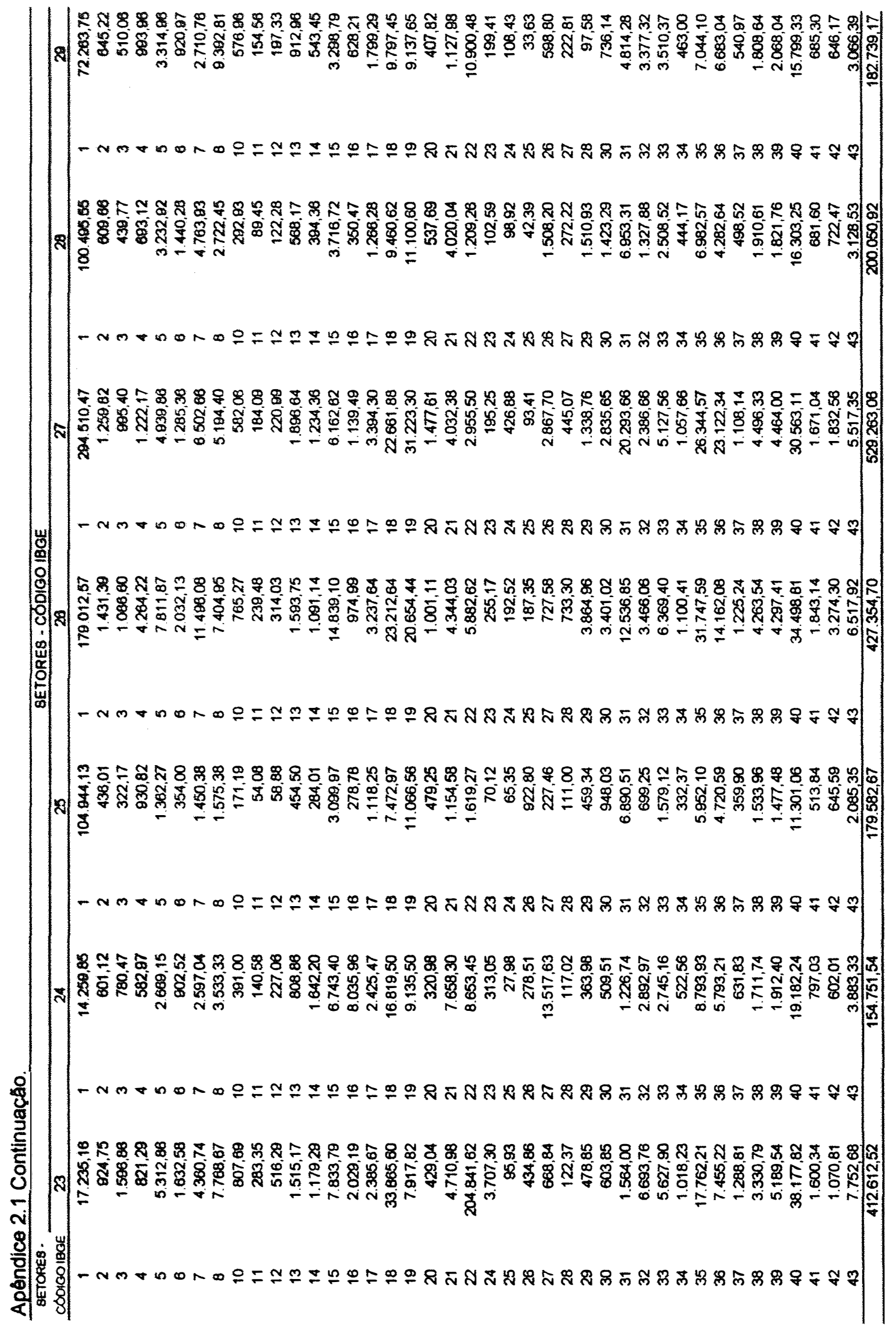




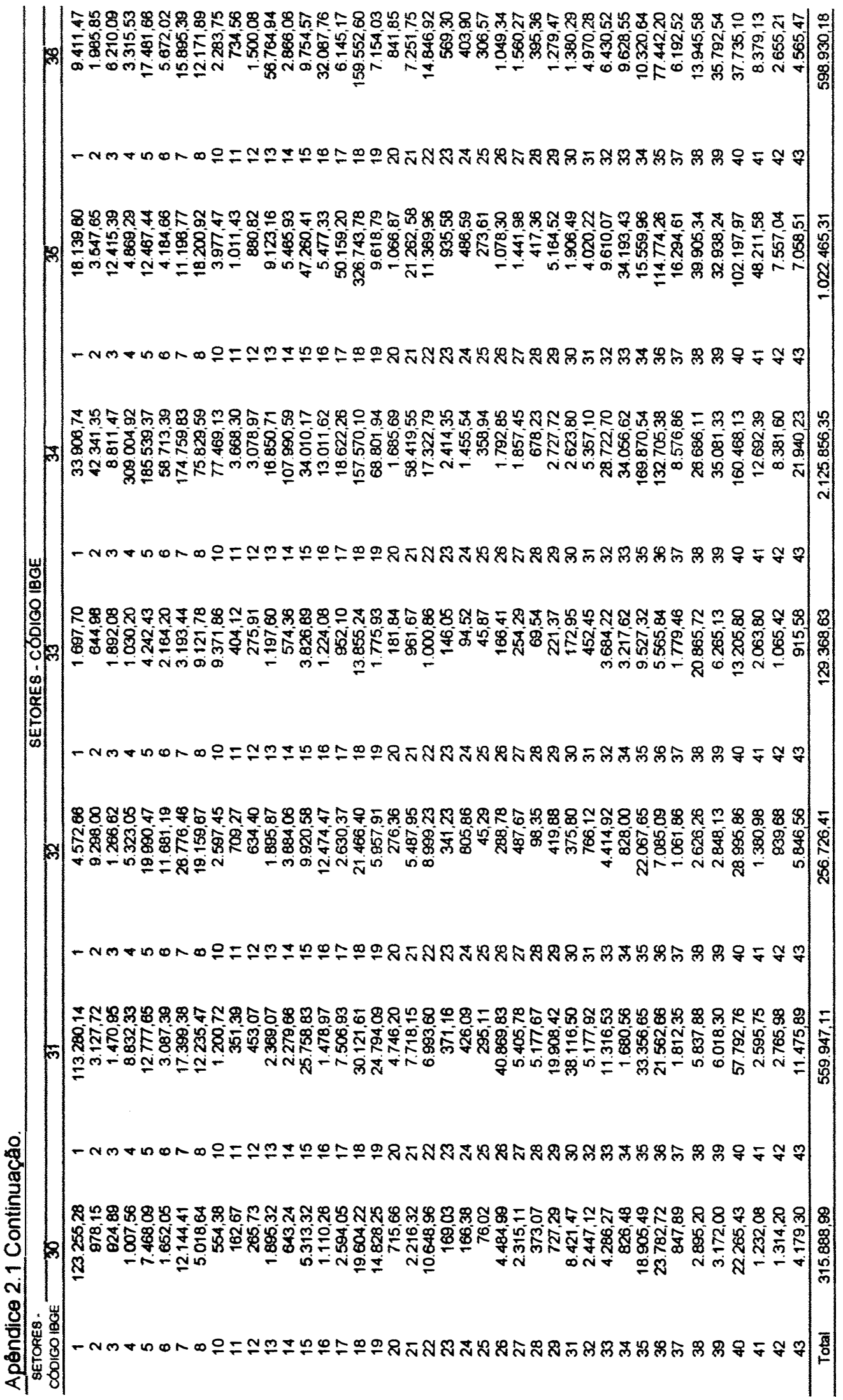




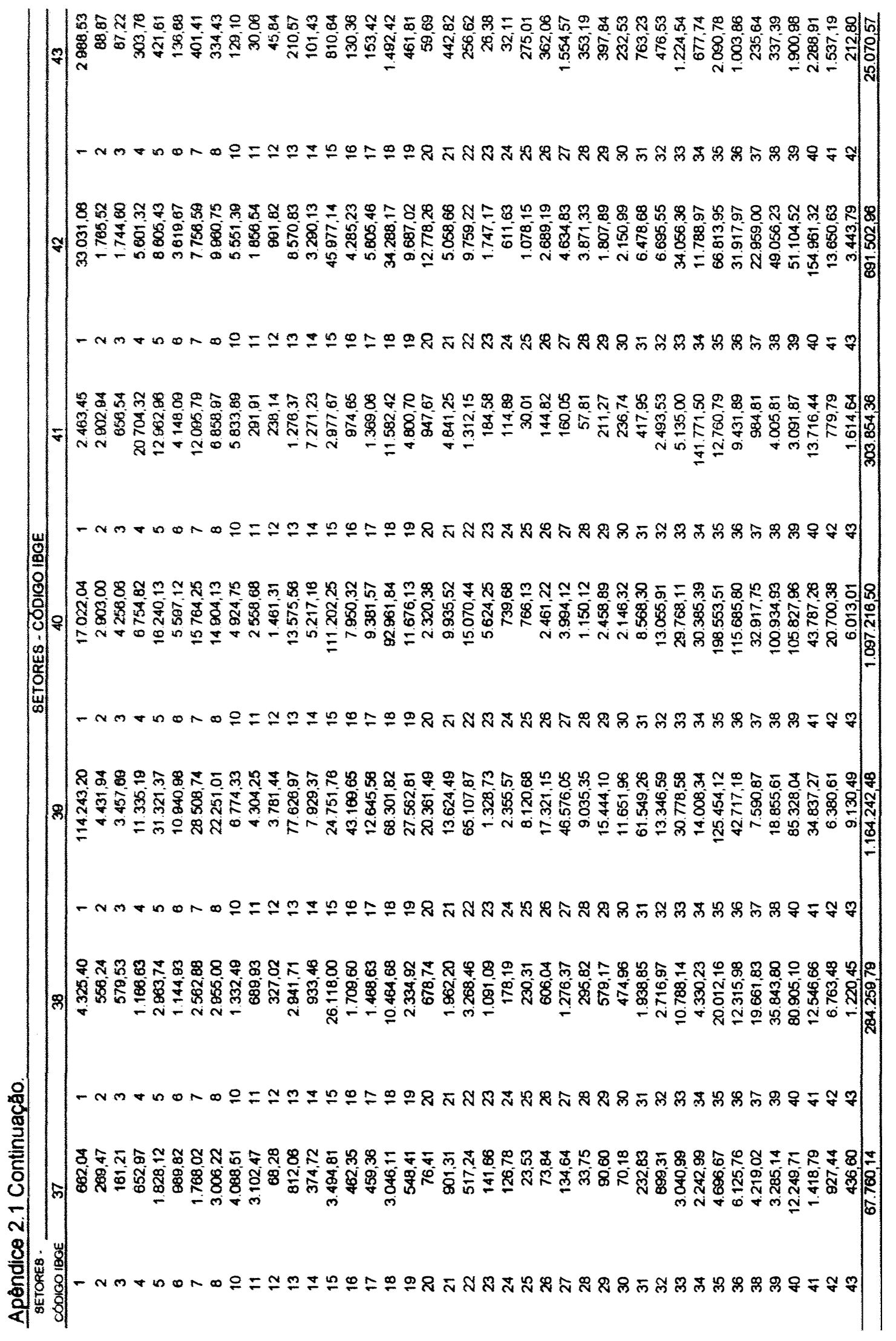




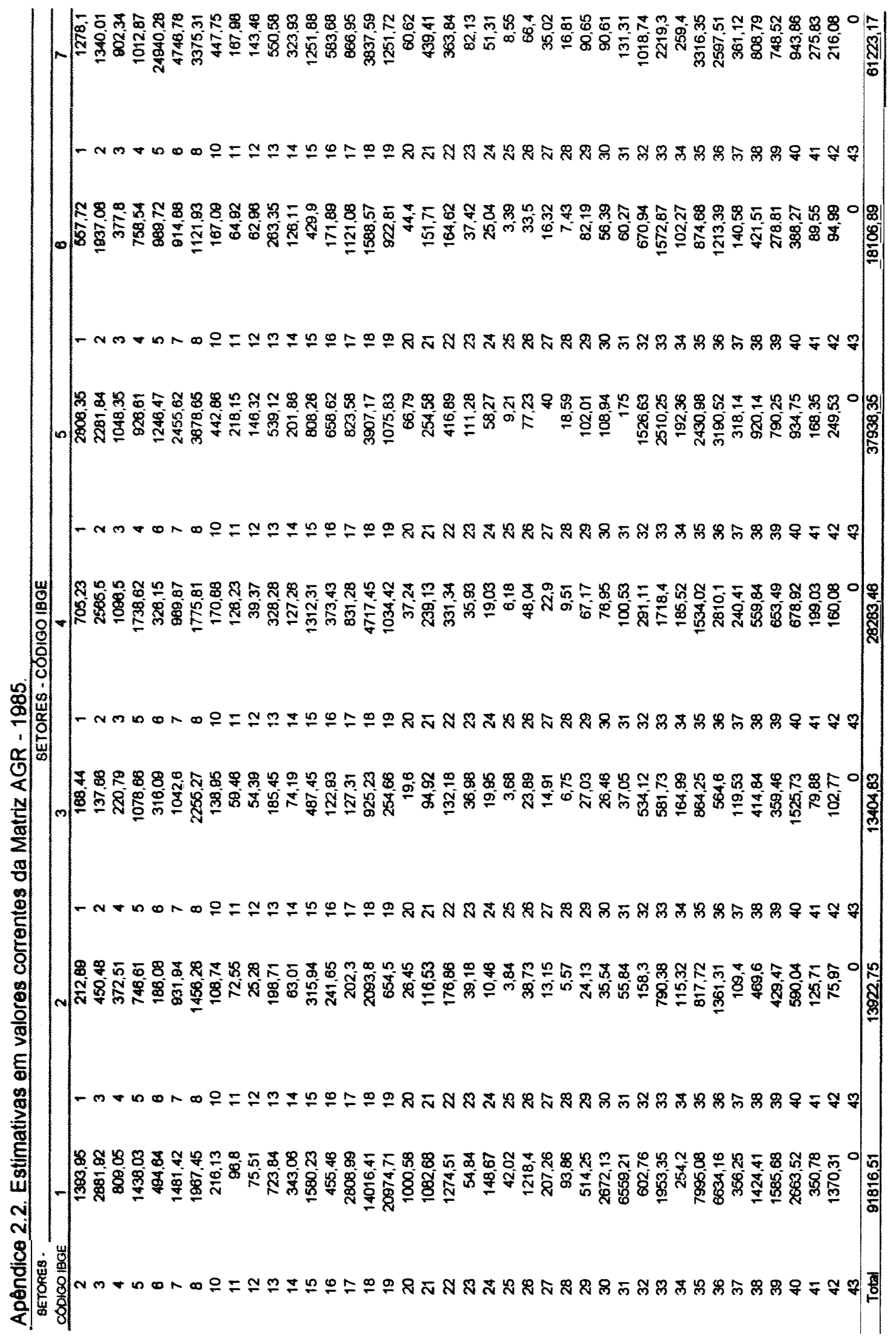




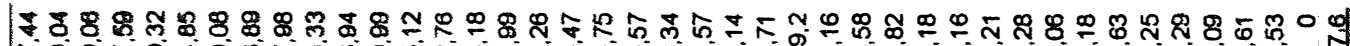

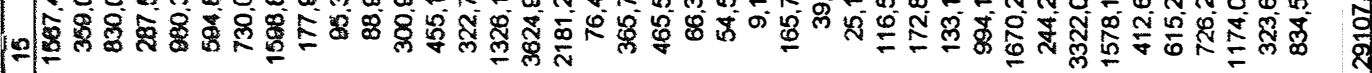

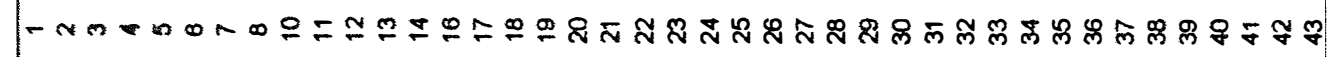

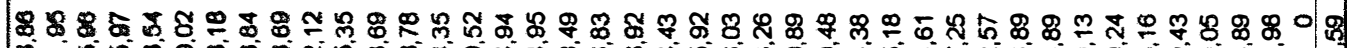

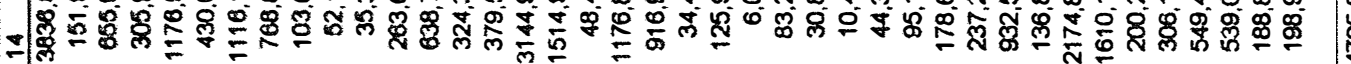

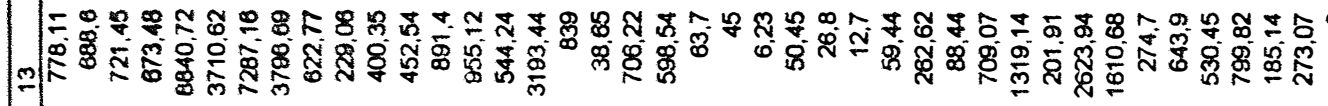

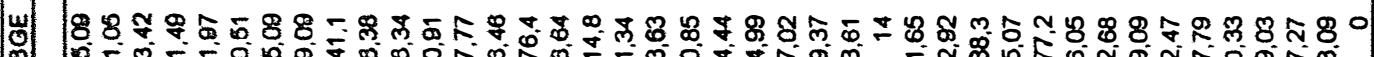

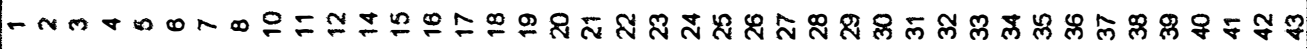

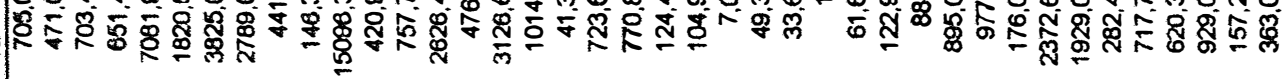

一 

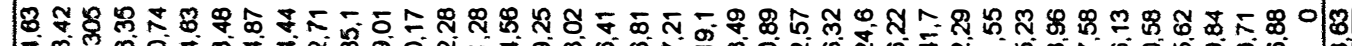

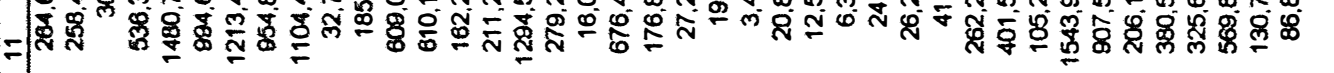

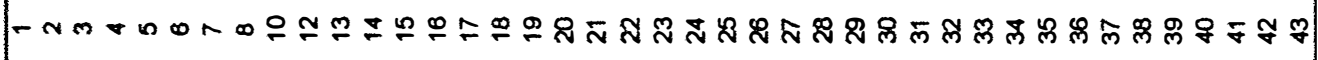

충ำ

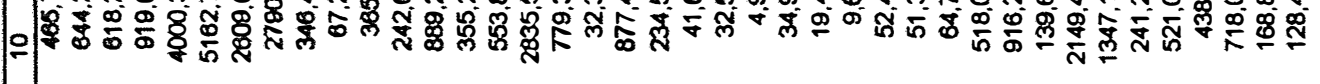

-

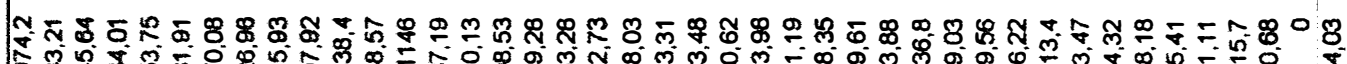

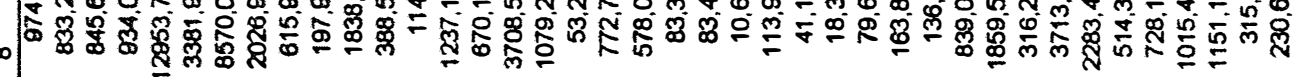
N 


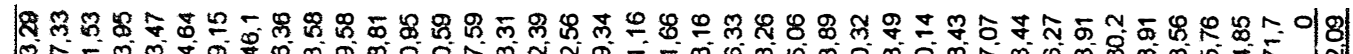
สে

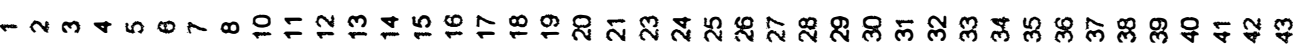

8: B స

-

8.

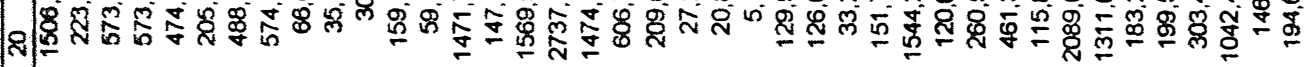

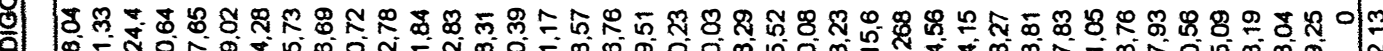

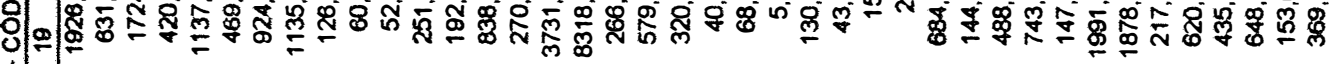

-

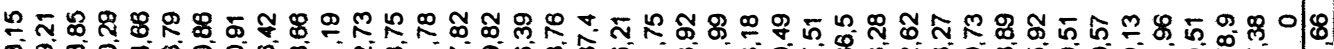

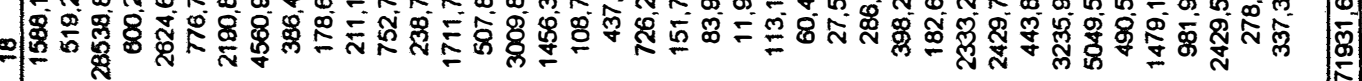

-

-

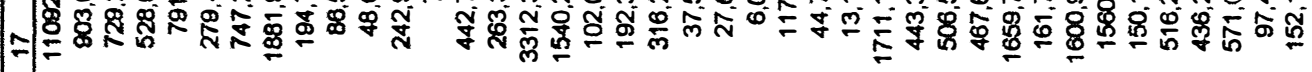

-

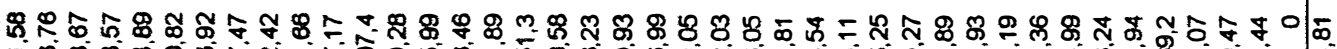

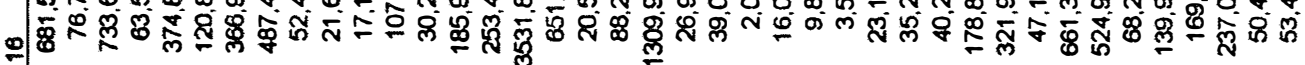




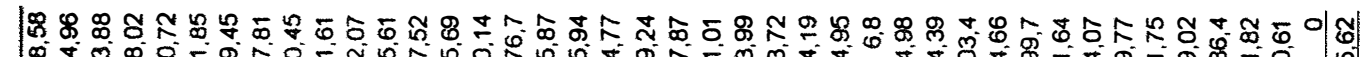

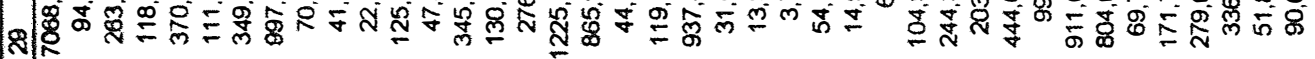

-

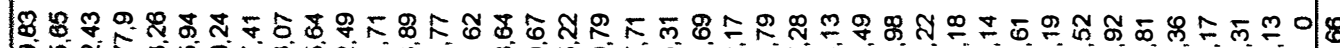

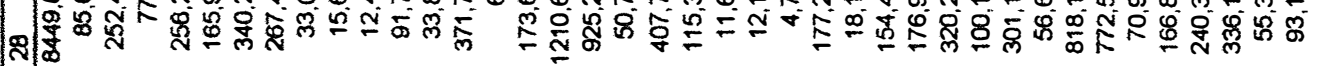

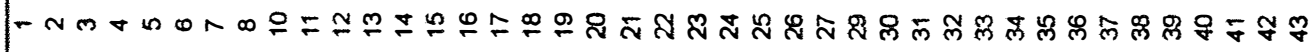

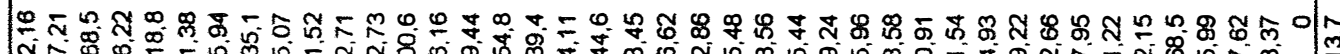

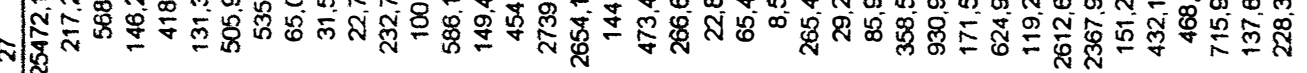

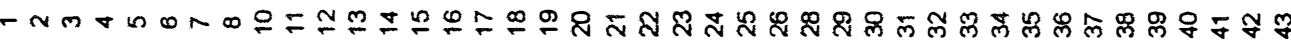

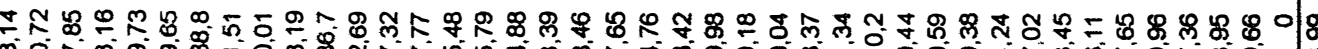

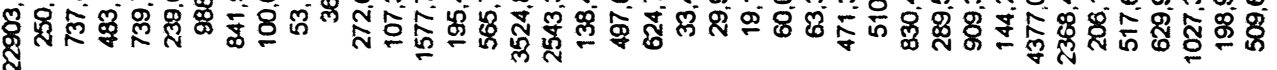

-

人

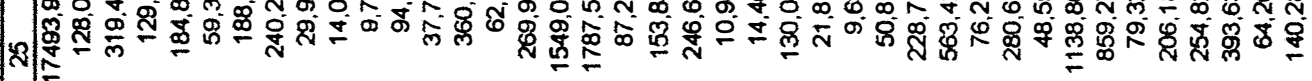

-

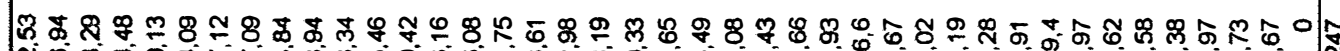

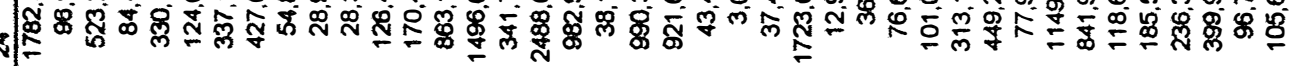

-

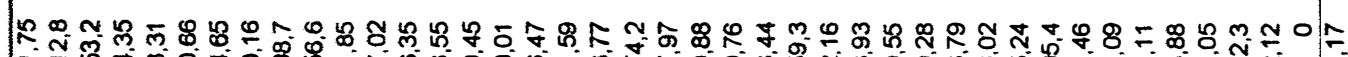
$\operatorname{sก}$

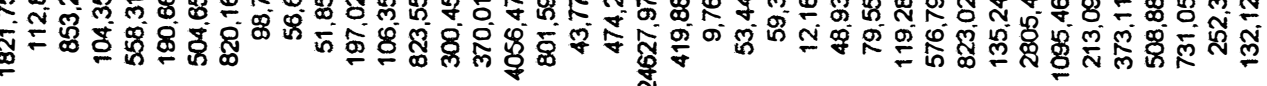
象

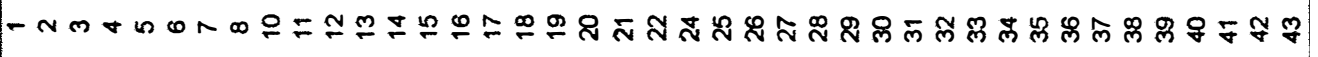




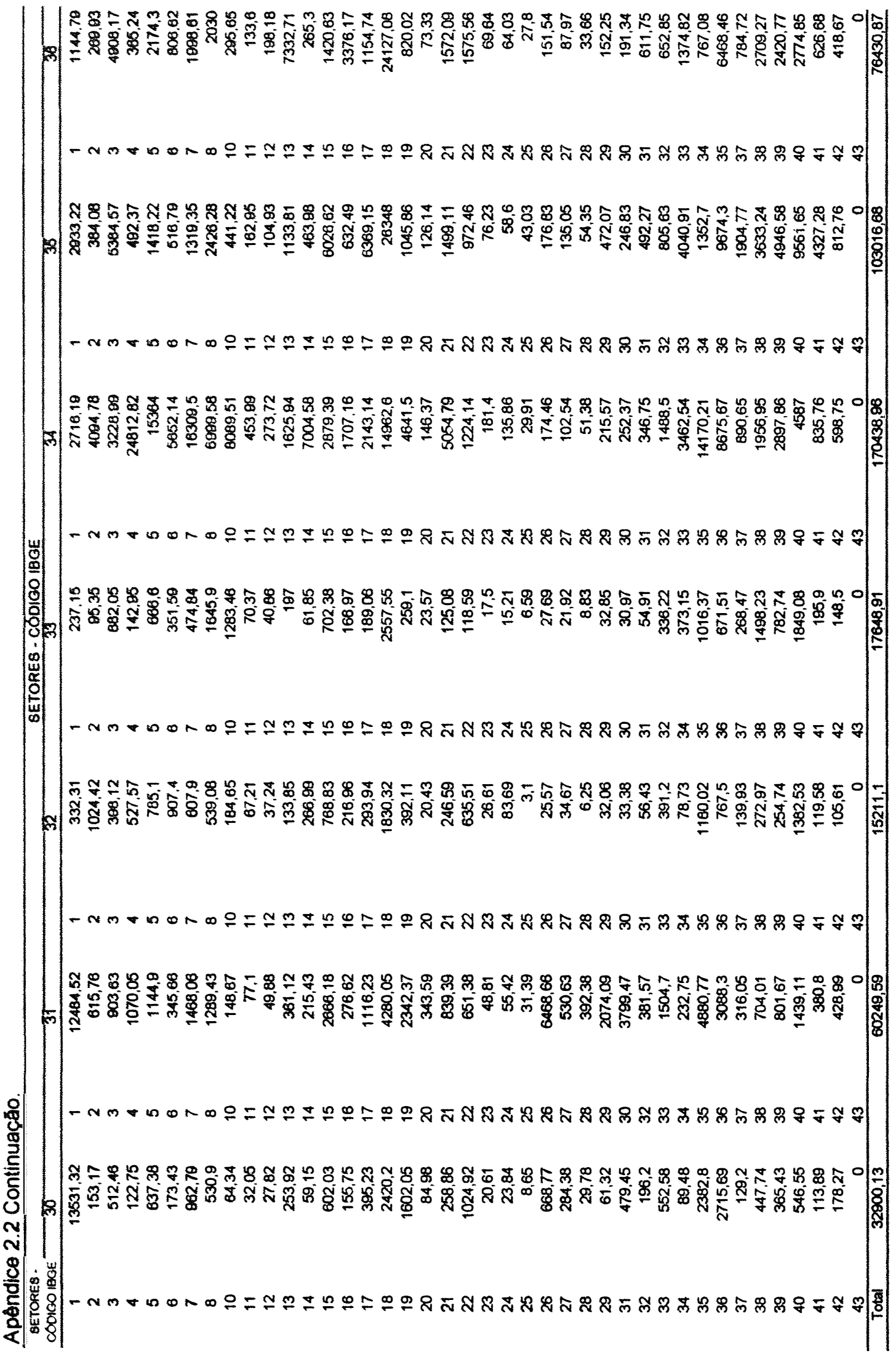


| केल्लि

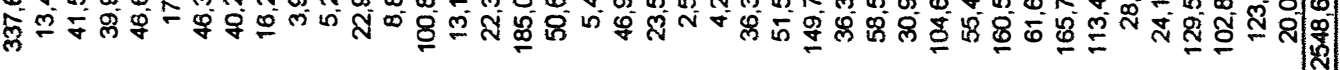

ー

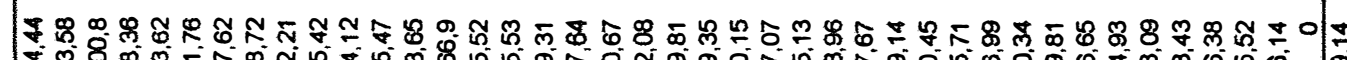

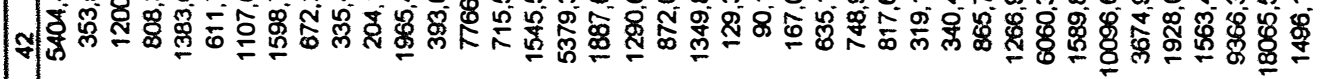

-

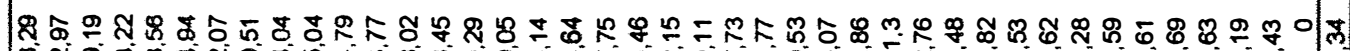
F

-

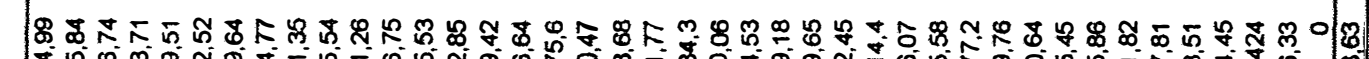

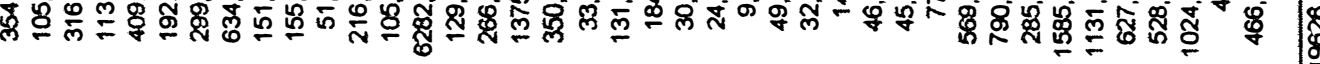

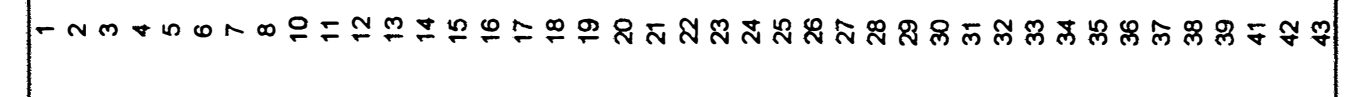

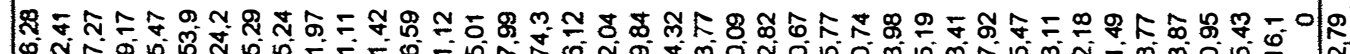

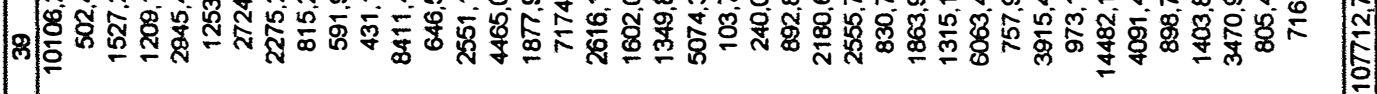

-

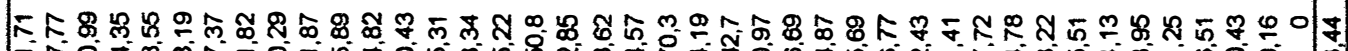
क

ー

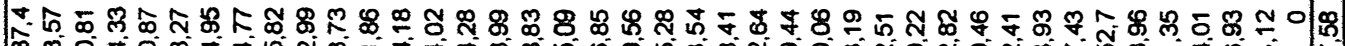
(m)

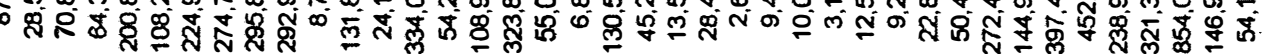

- 


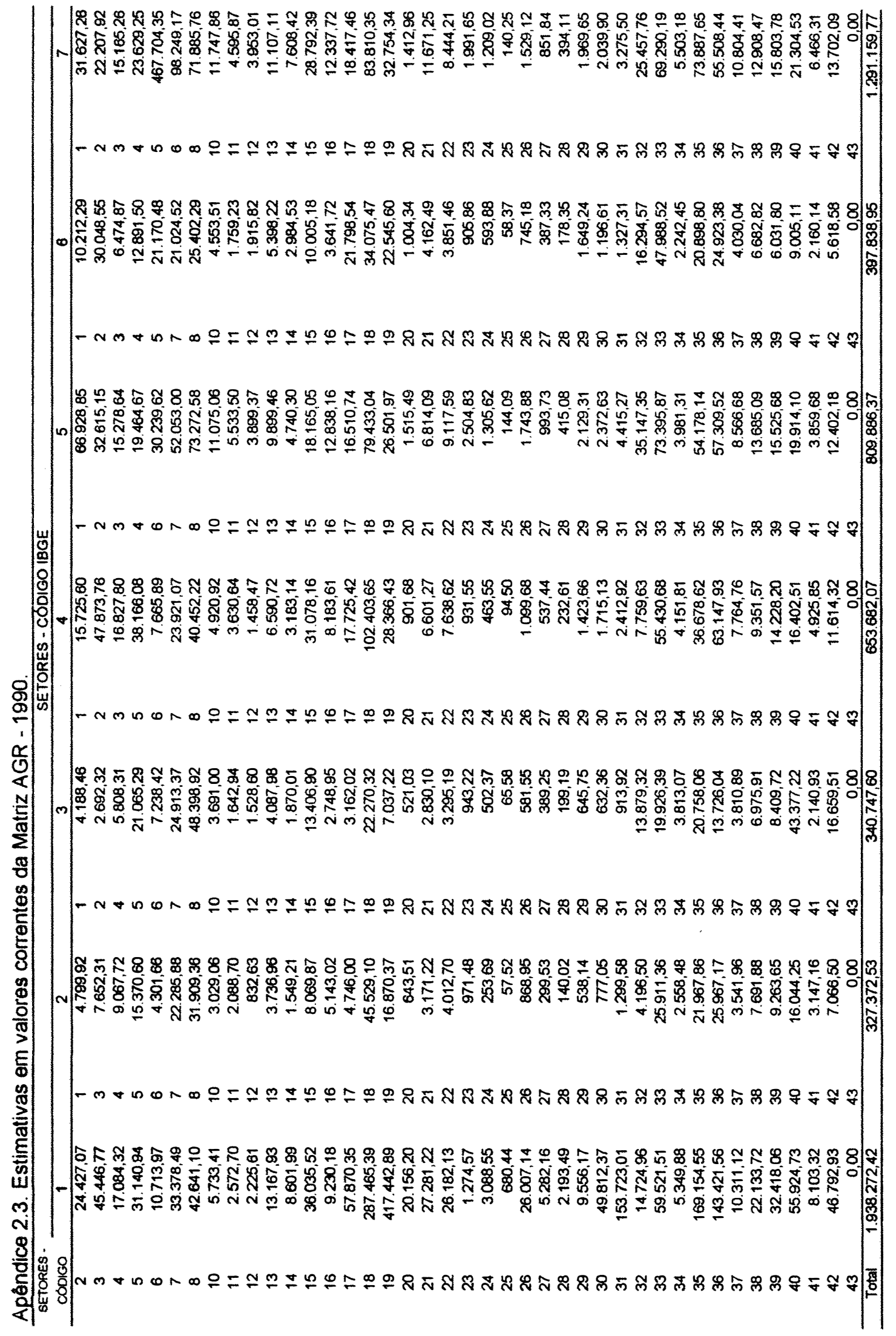




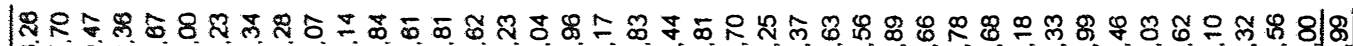

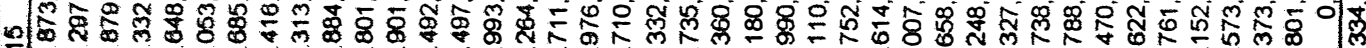

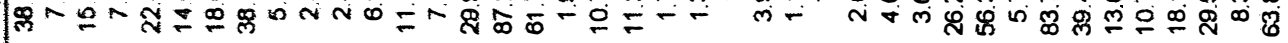

一ח

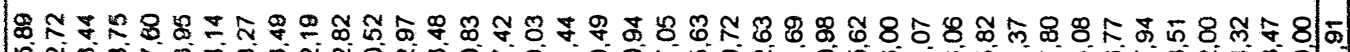

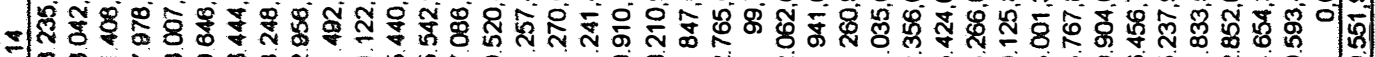

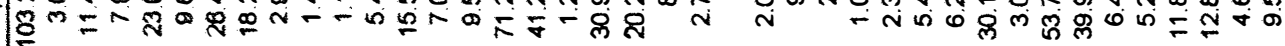

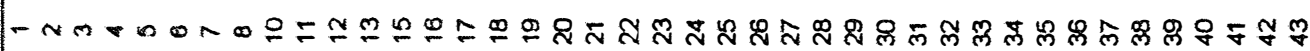

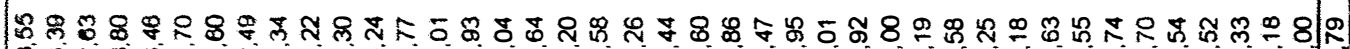

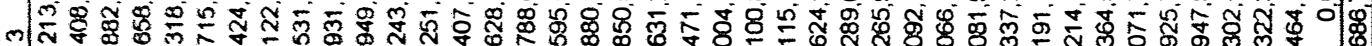

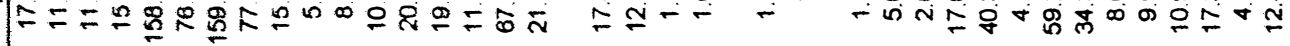

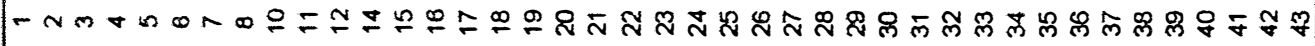

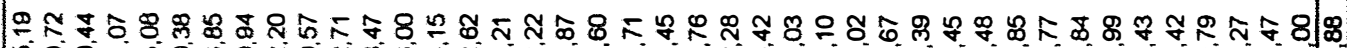

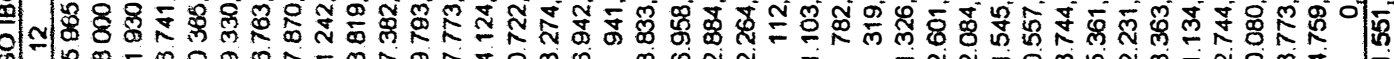

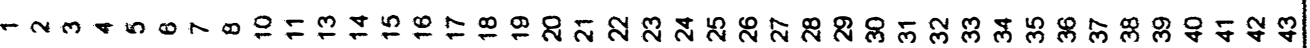

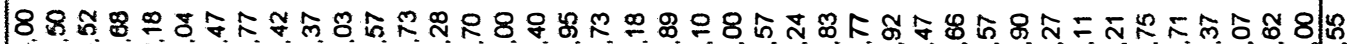

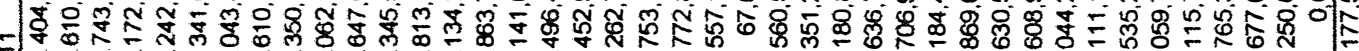

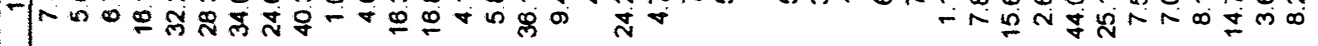

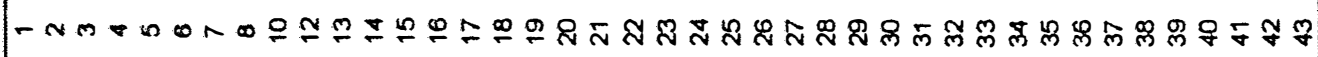

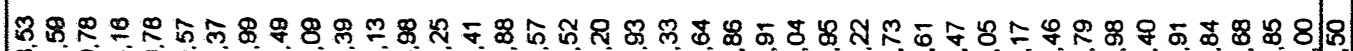

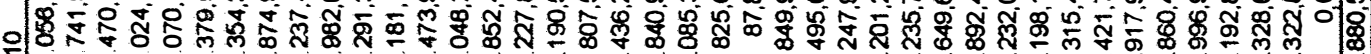

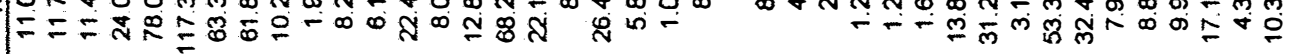

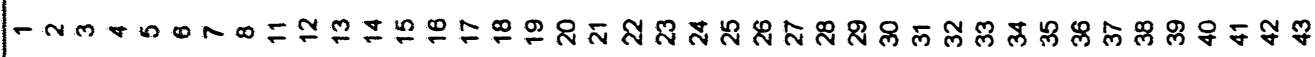

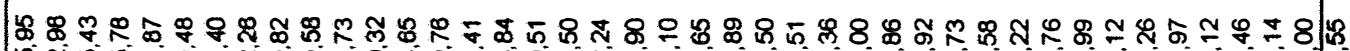

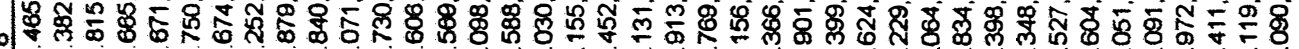

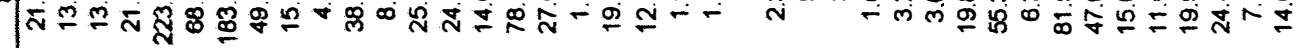
is

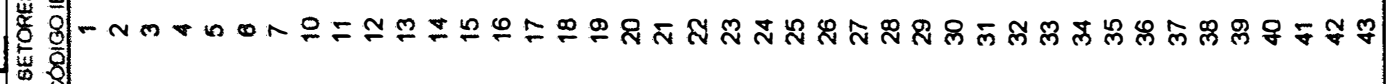




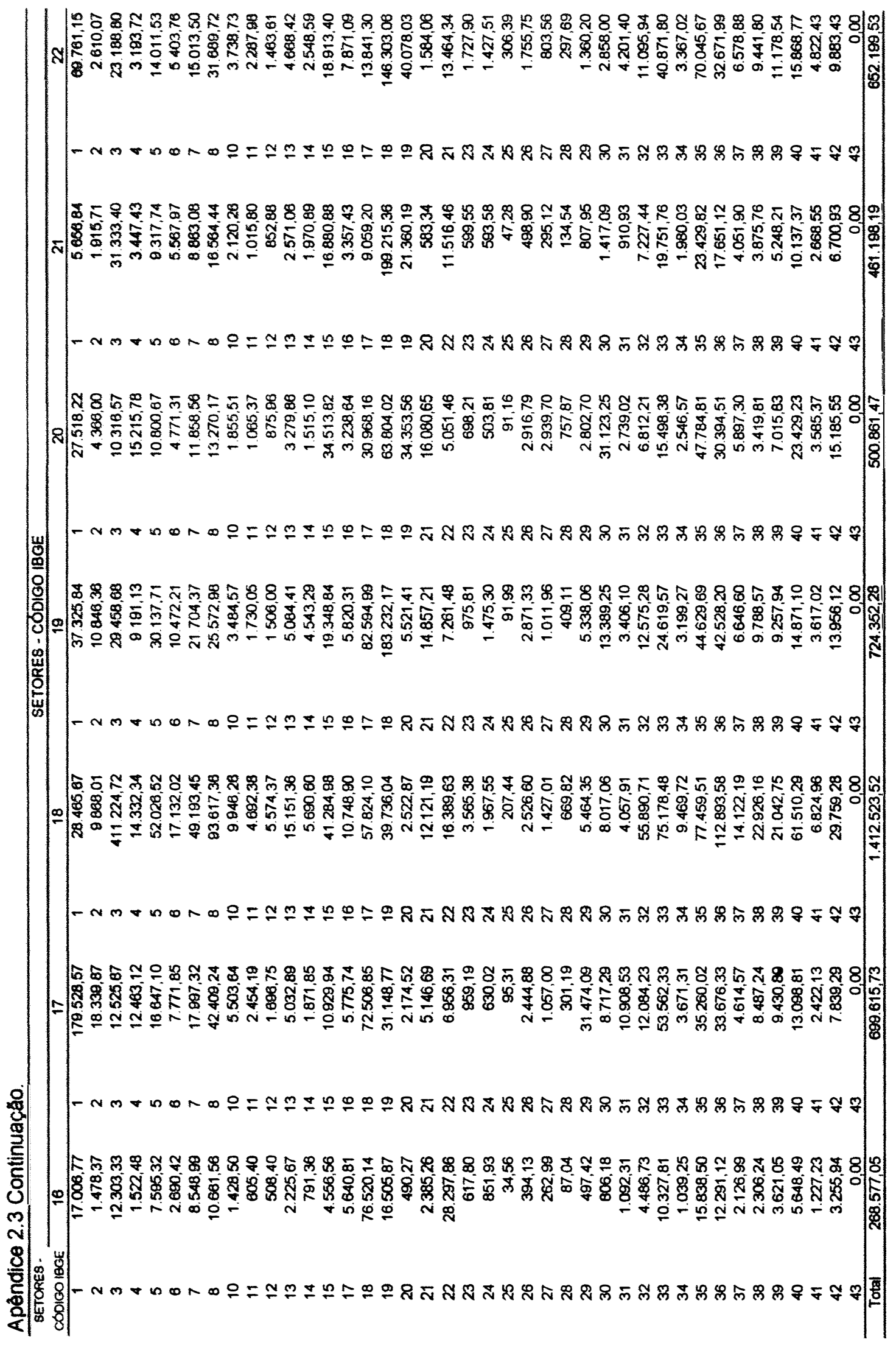




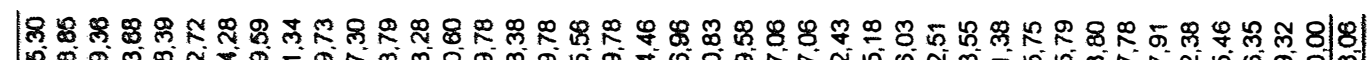

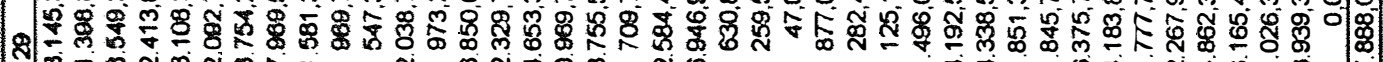

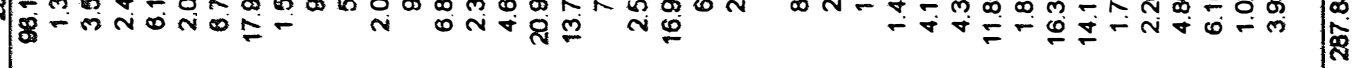

ー

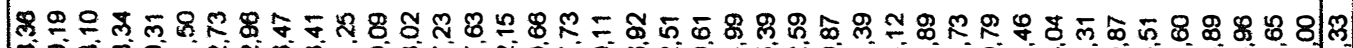

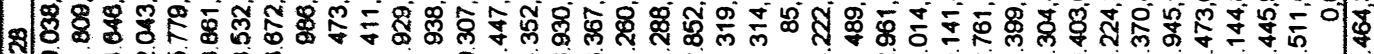

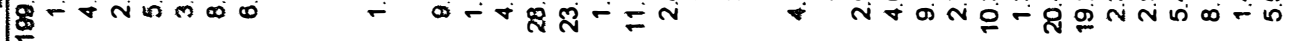

-

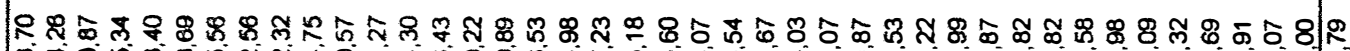

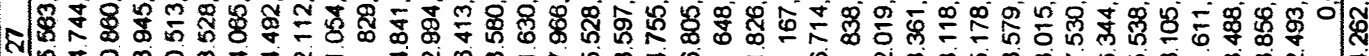

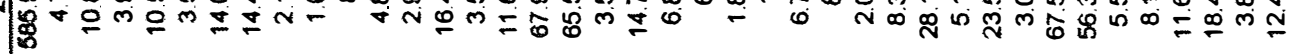

-

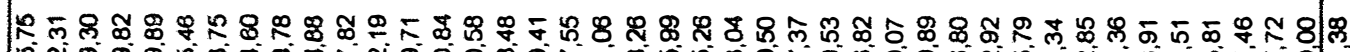

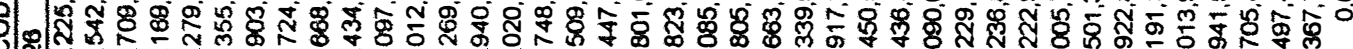

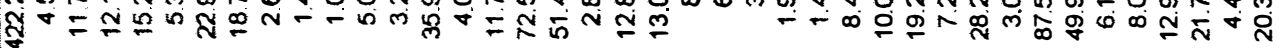

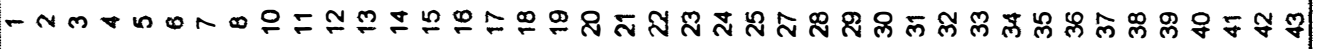

的

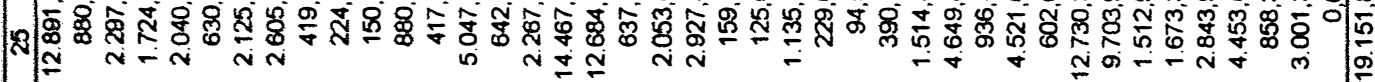
$=$

-

๘

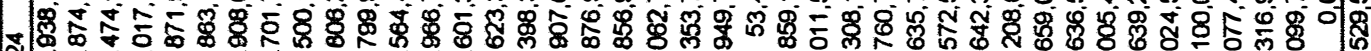

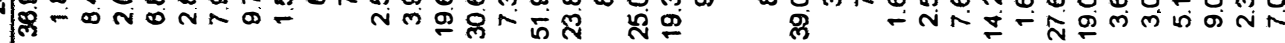

-

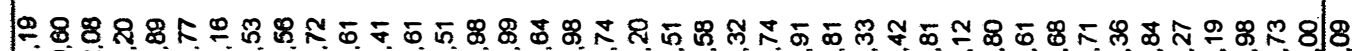

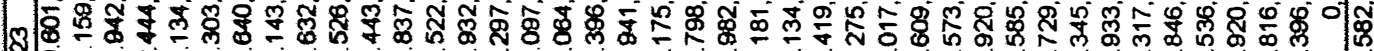

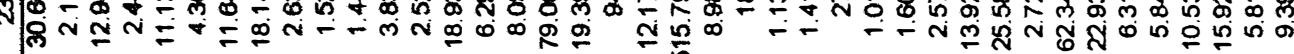




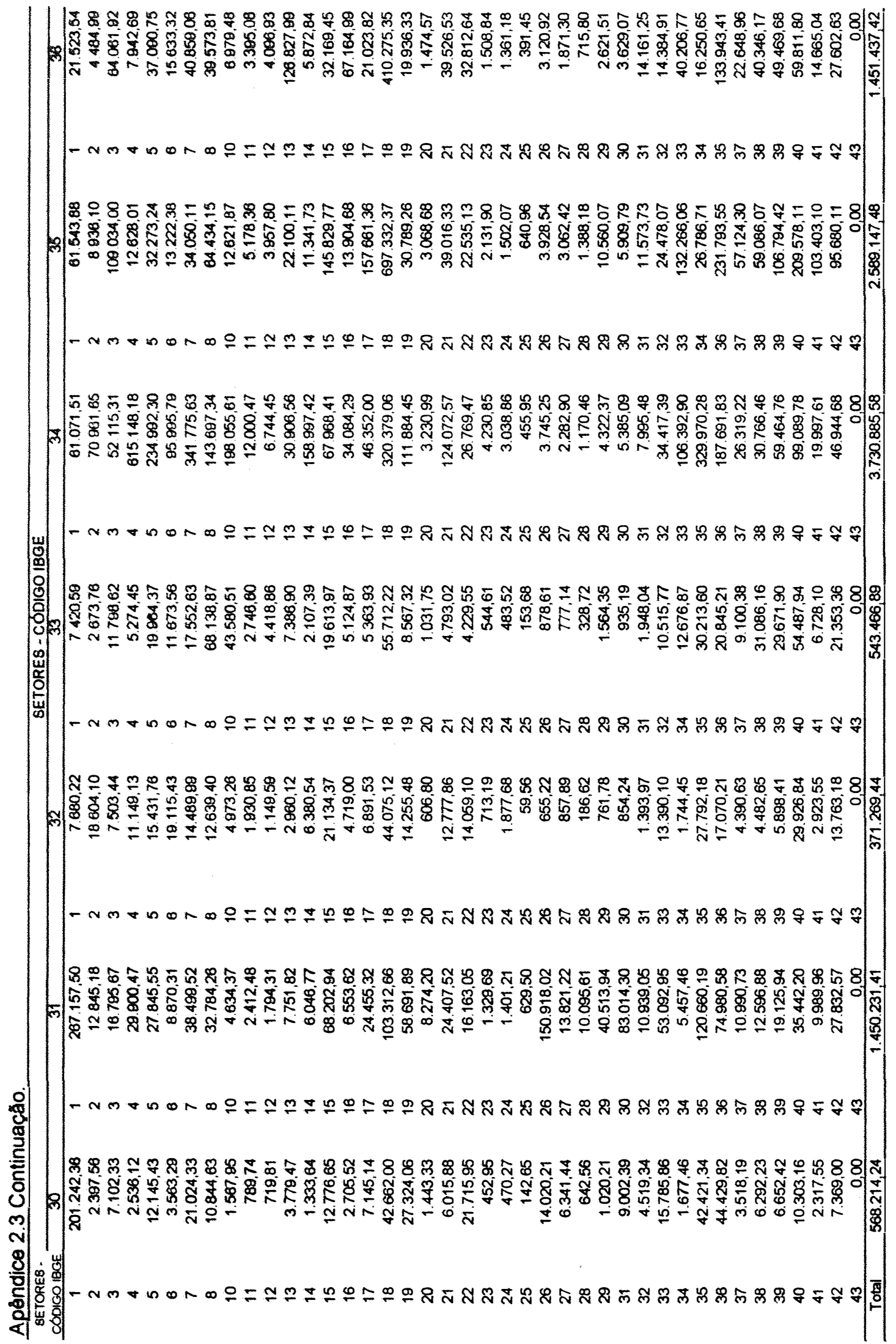




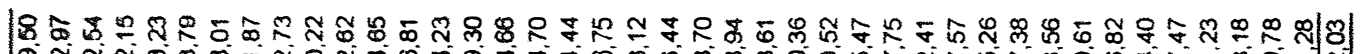
య

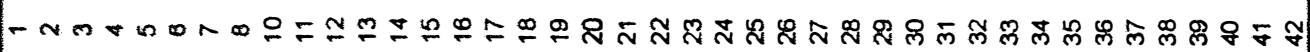

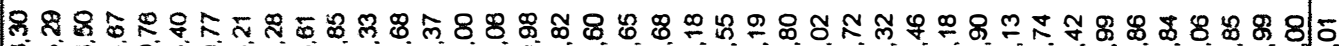

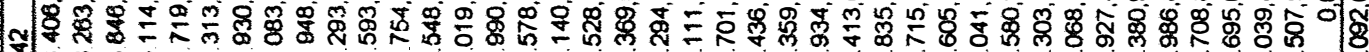

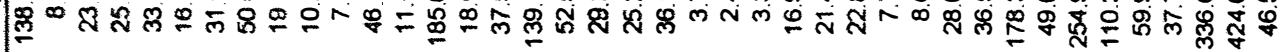

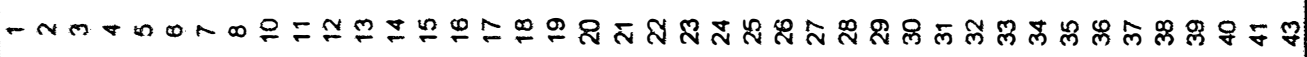

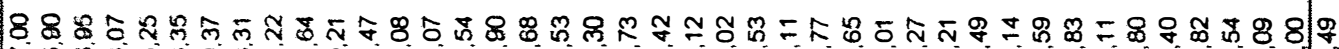

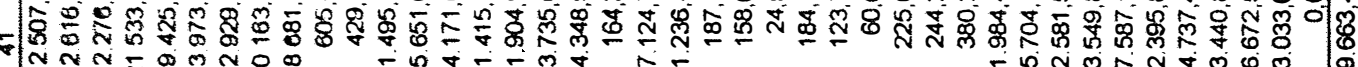

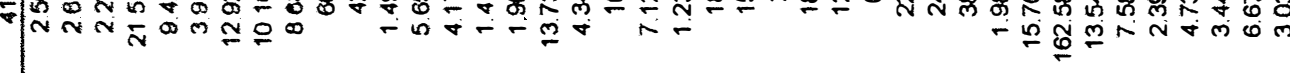

-

๑

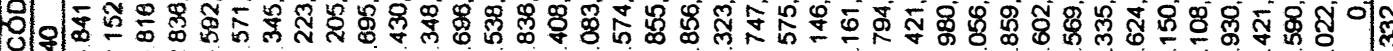

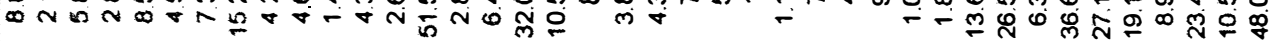

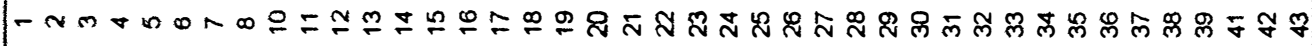

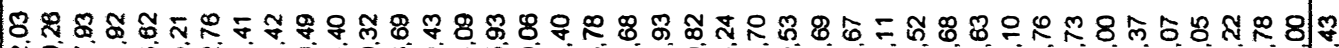

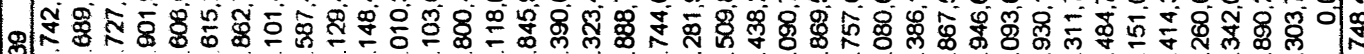

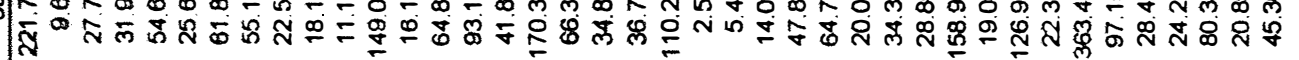

-

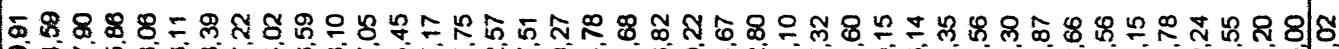

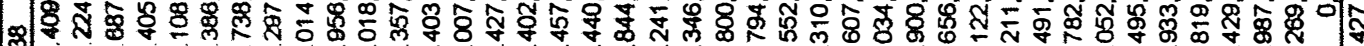

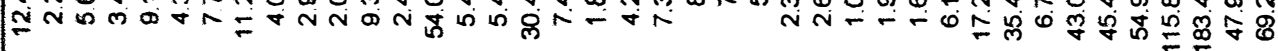

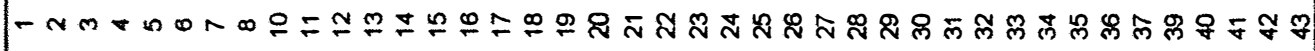

大 ल) 


\section{APÊNDICE 3}

Relação dos Índices de Preços utilizados no deflacionamento 


\begin{tabular}{|c|c|c|}
\hline \multicolumn{2}{|r|}{ Produto } & \multirow[b]{2}{*}{ Indice de Preços } \\
\hline $\begin{array}{l}\text { Código } \\
\text { IBGS }\end{array}$ & Descrição & \\
\hline 0101 & Café em Coco & $\begin{array}{l}\text { Produção Vegetal - Indice de preço pago } \\
\text { ao produtor }\end{array}$ \\
\hline 0102 & Cana-de-Açúcar & $\begin{array}{l}\text { Produção Vegetal - Indice de preço pago } \\
\text { ao produtor }\end{array}$ \\
\hline 0103 & Arroz em Casca & $\begin{array}{l}\text { Produção Vegetal - Indice de preço pago } \\
\text { ao produtor }\end{array}$ \\
\hline 0104 & Irigo em Grāo & $\begin{array}{l}\text { Produção Vegetal - Indice de preço pago } \\
\text { ao produtor }\end{array}$ \\
\hline 0105 & Soja em Grão & $\begin{array}{l}\text { Produção Vegetal - Indice de preço pago } \\
\text { ao produtor }\end{array}$ \\
\hline 0106 & Algodão em Grão & $\begin{array}{l}\text { Produção Vegetal - Indice de preço pago } \\
\text { ao produtor }\end{array}$ \\
\hline 0107 & Milho em Grão & $\begin{array}{l}\text { Produção Vegetal - Indice de preço pago } \\
\text { ao produtor }\end{array}$ \\
\hline 0108 & Bovinos e Suínos & $\begin{array}{l}\text { Produção Animal - Indice de preço pago } \\
\text { ao produtor }\end{array}$ \\
\hline 0109 & Leite Natural & $\begin{array}{l}\text { Produção Animal - Indice de preço pago } \\
\text { ao produtor }\end{array}$ \\
\hline 0110 & Aves Vivas & $\begin{array}{l}\text { Produção Animal - Indice de preço pago } \\
\text { ao produtor }\end{array}$ \\
\hline 0199 & $\begin{array}{l}\text { Outros Produtos } \\
\text { Agropecuários }\end{array}$ & $\begin{array}{l}\text { Agropecuária - Média das Atividades } \\
\text { mensuradas }\end{array}$ \\
\hline 0201 & Minério de Ferro & $\begin{array}{l}\text { IPA (Indice de Preço no Atacado) - } \\
\text { extrativa mineral }\end{array}$ \\
\hline 0202 & Outros Minerais & IPA - extrativa mineral \\
\hline 0301 & Petróleo e Gás & IPA - extrativa mineral \\
\hline 0302 & Carvăo e Outros & IPA - Extrativa mineral \\
\hline 0401 & $\begin{array}{l}\text { Produtos Minerais não } \\
\text { metálicos }\end{array}$ & IPA - Calcários e silicatos \\
\hline 0501 & $\begin{array}{l}\text { Produtos Siderúrgicos } \\
\text { básicos }\end{array}$ & IPA - Metalúrgica/Ferro/Aço \\
\hline 0502 & Laminados de Aço & IPA - Metalúrgica/Ferro/Aço \\
\hline 0601 & $\begin{array}{l}\text { Prod. Metalúrgicos não } \\
\text { Ferrosos }\end{array}$ & IPA - Metalúrgica não ferrosos \\
\hline 0701 & $\begin{array}{l}\text { Outros Produtos } \\
\text { Metalúrgicos }\end{array}$ & IPA - Metalúrgica total \\
\hline 0801 & $\begin{array}{l}\text { Eab. e Manut. de } \\
\text { Máq./Equipamentos }\end{array}$ & $\begin{array}{l}\text { IPA - Mecânica, Máquinas e Equipamentos } \\
\text { industriais }\end{array}$ \\
\hline 0802 & $\begin{array}{l}\text { Tratores e Máq. de } \\
\text { Terraplanagem }\end{array}$ & IPA - Mecânica, Máquinas agricolas \\
\hline 1001 & Material Elétrico & IPA - Total Material elétrico \\
\hline 1101 & Equip. Eletrônicos & IPA - Equipamentos eletrônicos \\
\hline 1201 & $\begin{array}{l}\text { Automóveis, Caminhões e } \\
\text { Ónibus }\end{array}$ & $\begin{array}{l}\text { IPA - Material de transporte - veículos } \\
\text { a motor }\end{array}$ \\
\hline 1301 & Outros Veiculos e Peças & IPA - Material transporte - outros \\
\hline 1401 & Madeira e Mobiliário & IPA - Total Mobiliário \\
\hline 1501 & $\begin{array}{l}\text { Papel, Celulose, } \\
\text { Papelão e Artef. }\end{array}$ & IPA - Papel, papelão \\
\hline 1601 & $\begin{array}{l}\text { Produtos Derivados da } \\
\text { Borracha }\end{array}$ & IPA - Borracha \\
\hline
\end{tabular}




\begin{tabular}{|c|c|c|c|}
\hline \multicolumn{2}{|r|}{ Produto } & \multirow{2}{*}{\multicolumn{2}{|c|}{ Índice de Preços }} \\
\hline $\begin{array}{l}\text { Código } \\
\text { IBGE }\end{array}$ & Descrição & & \\
\hline 1701 & $\begin{array}{l}\text { Elem. Quimicos não } \\
\text { Petroquimicos }\end{array}$ & $I P \bar{A}_{2}-$ & Quimica total \\
\hline 1702 & $\begin{array}{l}\text { Alcool de Cana e de } \\
\text { Cereais }\end{array}$ & $I P A-$ & Química total \\
\hline 1801 & Gasolina Pura & $I P A-$ & Química combustiveis/Iubrificantes \\
\hline 1802 & $\begin{array}{l}\text { Óleos Combustiveis e } \\
\text { óleo Diesel }\end{array}$ & IPA - & Quimica combustiveis/lubrificantes \\
\hline 1803 & $\begin{array}{l}\text { Outros Produtos do } \\
\text { Refino }\end{array}$ & $I P A-$ & Quimica combustiveis/lubrificantes \\
\hline 1804 & $\begin{array}{l}\text { Prod. Petroquímicos } \\
\text { Básicos }\end{array}$ & $I P A-$ & Quimica combustiveis/lubrificantes \\
\hline 1805 & Resinas & $I P A-$ & Quimica combustiveis/lubrificantes \\
\hline 1806 & Gasoálcool & IPA - & Quimica combustiveis/lubrificantes \\
\hline 1901 & Adubos & IPA - & Química fertilizantes \\
\hline 1902 & Tintas & $I P A-$ & Quimica tintas e vernizes \\
\hline 1903 & Outros Prod. químicos & $I P A-$ & Quimica total \\
\hline 2001 & $\begin{array}{l}\text { Prod. Earmacêuticos e } \\
\text { Perfumaria }\end{array}$ & IPA - & Química total \\
\hline 2101 & Artigos de Plástico & $I P A-$ & Quimica total \\
\hline 2201 & Fios Têxteis Naturais & IPA - & Tecidos naturais \\
\hline 2202 & Tecidos Naturais & IPA - & Tecidos naturais \\
\hline 2203 & $\begin{array}{l}\text { Eios Têxteis } \\
\text { Artificiais }\end{array}$ & IPA - & Tecidos artificiais \\
\hline 2204 & Tecidos Artificiais & IPA - & Tecidos artificiais \\
\hline 2205 & Outros Prod. Têxteis & IPA - & Total tecidos \\
\hline 2301 & Artigos do Vestuário & $I P A-$ & Vestuário \\
\hline 2401 & $\begin{array}{l}\text { Produtos de Couro e } \\
\text { Calçados }\end{array}$ & IPA - & Calçados \\
\hline 2501 & Produtos do Café & IPA - & Total origem vegetal \\
\hline 2601 & Arroz Beneficiado & IPA - & Total origem vegetal \\
\hline 2602 & Earinha de Trigo & IPA - & Farinha e derivados \\
\hline 2603 & $\begin{array}{l}\text { Outros Prod. Vegetais } \\
\text { Beneficiados }\end{array}$ & IPA - & Total origem vegetal \\
\hline 2701 & Carne bovina & $I P A-$ & Carnes e pescados \\
\hline 2702 & Carne de Aves Abatidas & $I P A-$ & Carnes e pescados \\
\hline 2801 & Leite Beneficiado & IPA - & Leite e derivados \\
\hline 2802 & Outros Laticínios & IPA - & Leite e derivados \\
\hline 2901 & Açúcar & $I P A-$ & Açúcar \\
\hline 3001 & Oleos vegetais em Bruto & IPA - & oleos e gorduras \\
\hline 3002 & $\begin{array}{l}\text { Oleos Vegetais } \\
\text { Refinados }\end{array}$ & $I P A-$ & Oleos e gorduras \\
\hline 3101 & $\begin{array}{l}\text { Rações e outros Prod. } \\
\text { Alimentares }\end{array}$ & IPA - & Sal, rações e outros \\
\hline 3102 & Bebidas & $I P A-$ & Total bebidas \\
\hline 3201 & Produtos Diversos & $I P A-$ & Total indústria transformação \\
\hline 3301 & $\begin{array}{l}\text { Serv. Industriais } \\
\text { Utilidade pública }\end{array}$ & IPA - & Total (disponibilidade interna) \\
\hline 3401 & $\begin{array}{l}\text { Produtos da Construção } \\
\text { Civil }\end{array}$ & $\begin{array}{l}\text { Indice } \\
\text { lmédia }\end{array}$ & $\begin{array}{l}\text { e Nacional Construção Civil } \\
\text { a) }\end{array}$ \\
\hline
\end{tabular}




\begin{tabular}{|c|c|c|}
\hline \multicolumn{2}{|r|}{ Prodiuto } & \multirow[b]{2}{*}{ Indice de Preços } \\
\hline $\begin{array}{l}\text { Código } \\
\text { IBGS }\end{array}$ & Descrigão & \\
\hline 3501 & Margem de Eomércio & $\begin{array}{l}\text { IGP - Indice Geral Preços - Conceito } \\
\text { disponibilidade interna }\end{array}$ \\
\hline 3601 & Margen de Transporte & IGP - Conceito disponibilidade interna \\
\hline 3701 & Comunicaçoes & IGP - Conceito disponibilidade interna \\
\hline 3801 & Seguros & IGP - Conceito disponibilidade interna \\
\hline 3802 & Servicos Einanceiros & IGP - Conceito disponibilidade interna \\
\hline 3901 & $\begin{array}{l}\text { Alojamento e } \\
\text { Alimentacào }\end{array}$ & IGP - Conceito disponibilidade interna \\
\hline 3902 & outros serviços & IGP - Conceito disponibilidade interna \\
\hline 3903 & $\begin{array}{l}\text { Saúde e Educação } \\
\text { Mercantis }\end{array}$ & IGP - Conceito disponibilidade interna \\
\hline 4001 & $\begin{array}{l}\text { Servicos Erestados às } \\
\text { Empresas }\end{array}$ & IGP - Conceito disponibilidade interna \\
\hline 4101 & Aluguei de Inoveis & IGP - Conceito disponibilidade interna \\
\hline$\div 102$ & Aluguel zmpucaco & IGP - Conceito disponibilidade interna \\
\hline 4201 & Administraçào füblica & IGP - Conceito disponibilidade interna \\
\hline 4202 & Saúde Pública & IGP - Conceito disponibilidade interna \\
\hline 4203 & Educaça Fública & IGP - Conceito disponibilidade interna \\
\hline 4301 & $\begin{array}{l}\text { Servicos Erivados não } \\
\text { mercantis }\end{array}$ & IGP - Conceito disponibilidade interna \\
\hline
\end{tabular}




\section{APÊNDICE 4}

\section{Representação em reais (RS) das estimativas do Produto Interno Bruto}

A 4.1. Produto Interno Bruto a Custo de Fatores do Complexo Agroindustrial

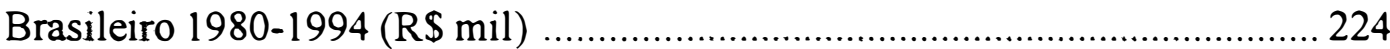

A 4.2. Produto Interno Bruto a Custo de Fatores do Complexo Agroindustrial Brasileiro 1980-1994 (R\$ mil). versão 1

A 4.3. Produto Interno Bruto a Custo de Fatores do Complexo Agroindustrial. Brasileiro 1980-1994 (R\$ mil). versão 2

A 4.4. Produto Intemo Bruto a Custo de Fatores do Complexo Agroindustrial. Brasileiro 1980-1994 (R\$ mil). versão 3

A4.5. Produto Interno Bruto a Custo de Fatores, segundo as classes de atividade econômica e Produto Interno Bruto a preços de mercado Brasil 1980-1994 (R\$ mil). 


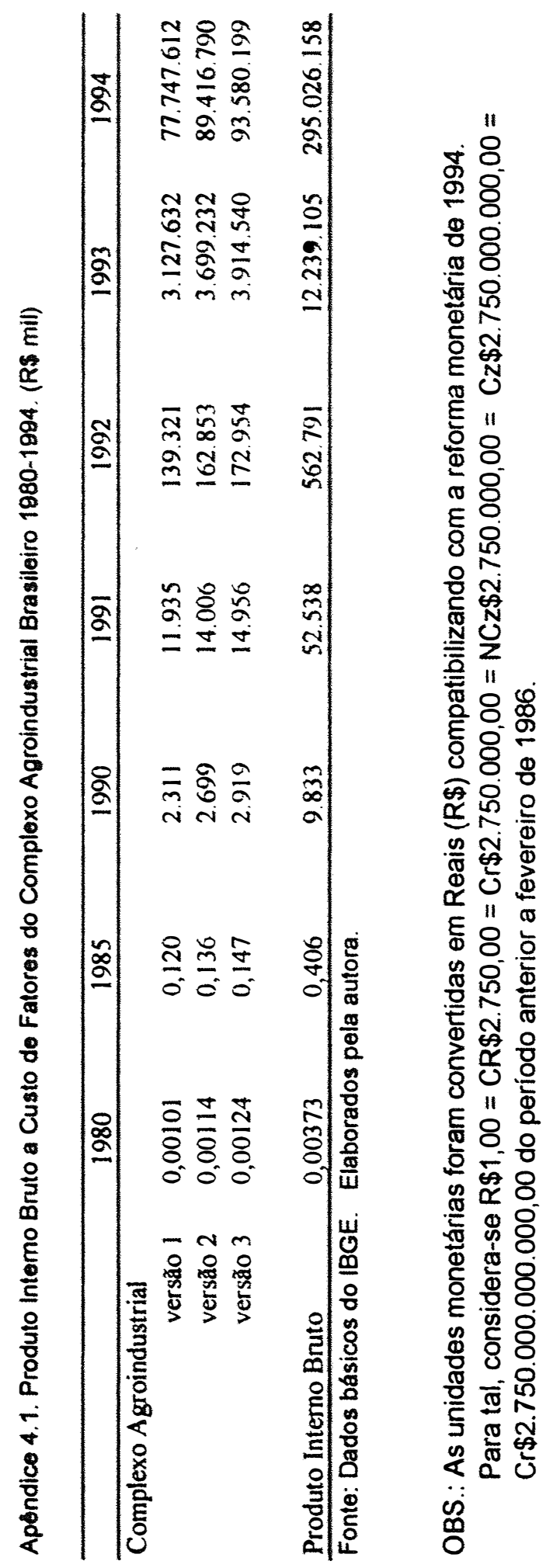




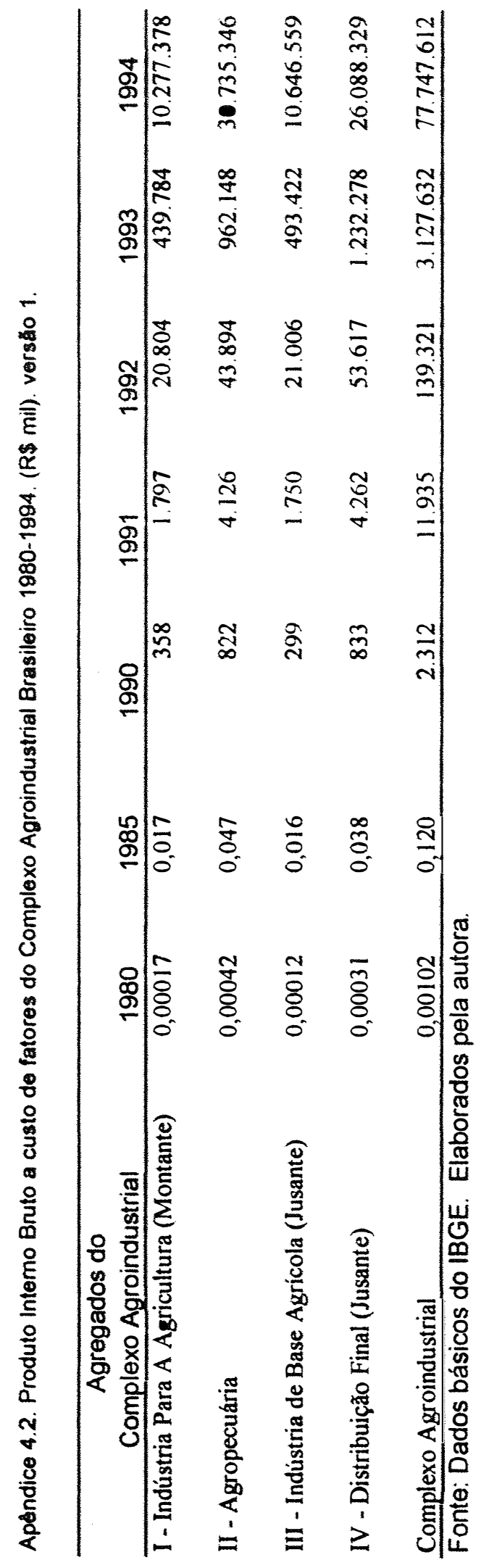




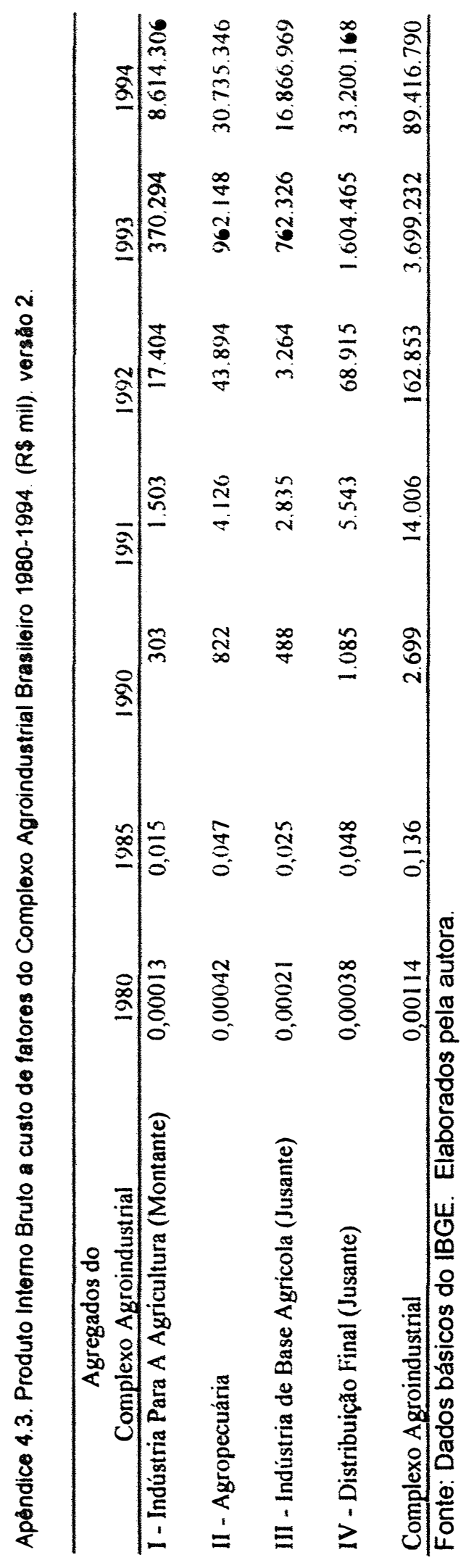




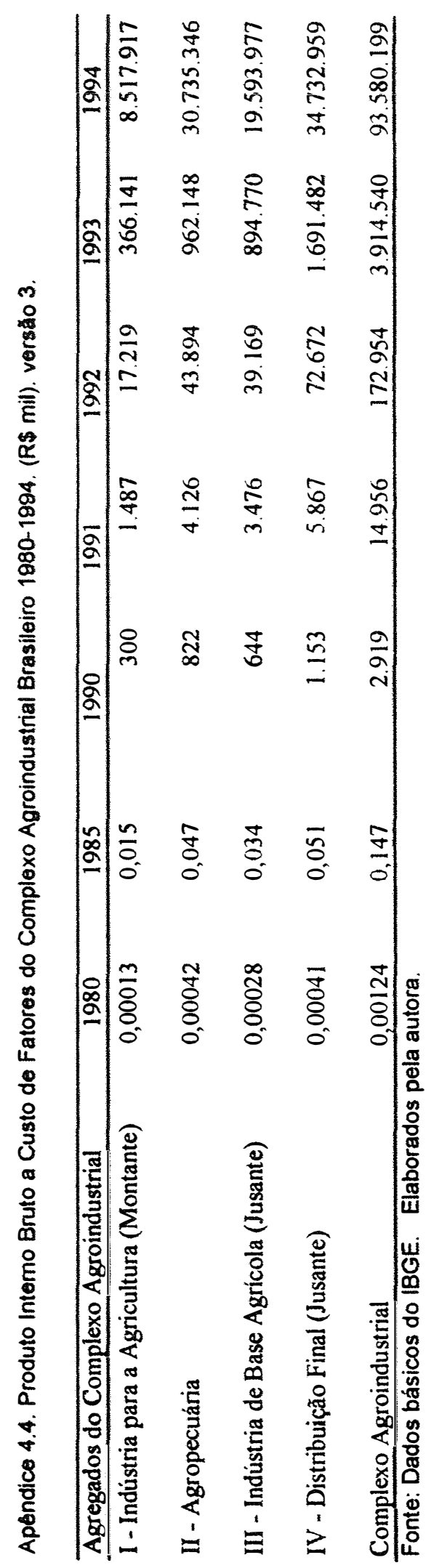




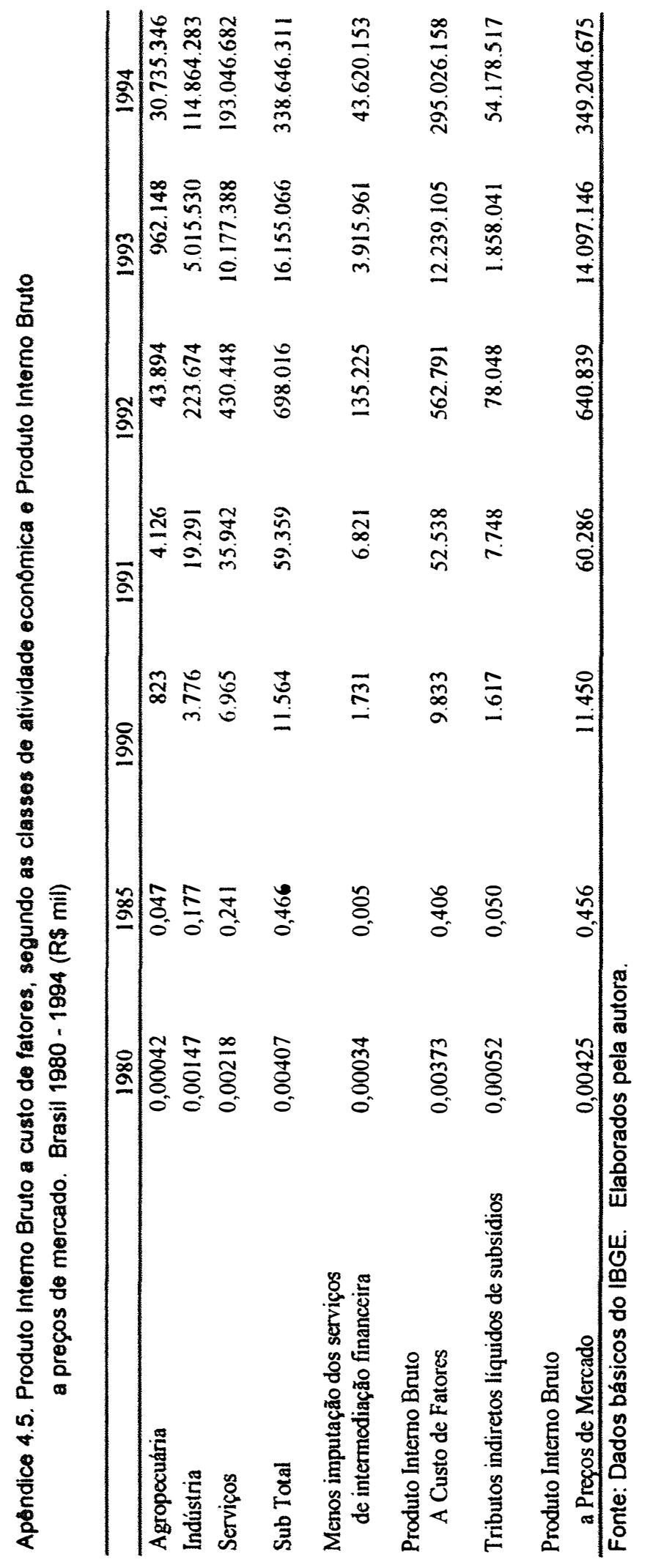




\section{APÊNDICE 5}

A 5.1 Estimativas a preços constantes do valor adicionado das diferentes atividades produtivas brasileiras, deflacionadas por produto $-1980 \ldots$

A 5.2 Estimativas a preços constantes do valor adicionado das diferentes atividades produtivas brasileiras, deflacionadas por produto - 1985 .....

A 5.3 Estimativas a preços constantes do valor adicionado das diferentes atividades produtivas brasileiras, deflacionadas por produto - $1990 \ldots$.

A 5.4 Estimativas a preços constantes do valor adicionado das diferentes atividades produtivas brasileiras, deflacionadas por produto $-1991 \ldots .$.

A 5.5 Estimativas a preços constantes do valor adicionado das diferentes atividades produtivas brasileiras, deflacionadas por produto $-1992 \ldots .$.

A 5.6 Estimativas a preços constantes do valor adicionado das diferentes atividades produtivas brasileiras, deflacionadas por produto $-1993 \ldots . .$.

A 5.7 Estimativas a preços constantes do valor adicionado das diferentes atividades produtivas brasileiras, deflacionadas por produto $-1994 \ldots . .$. 
Apêndice 5.1. Estimativas a preços constantes do valor adicionado das diferentes atividades produtivas brasileiras, deflacionadas por produto - 1980 .

\begin{tabular}{|c|c|c|c|c|c|}
\hline \multirow[b]{2}{*}{ cótico } & \multicolumn{5}{|c|}{ Descriça do Produto Nivel 80} \\
\hline & 01 & 02 & 03 & 04 & 05 \\
\hline PRODUTO & & EXTRATIVA & PETRÓLEO & MINERAL & \\
\hline NVEL 80 & AGROPECUÁRIA & MINERAL & E GAS & Ñ METÁLICO & SIDERURGIA \\
\hline Valor da Produçáo & 46241757,43 & 1739701,001 & 599477,5756 & 18392317,3 & 8076154,58 \\
\hline Consumo Intermediário & 16889532 & 1983657,179 & 609610,0778 & 6831035,952 & 9790954,505 \\
\hline Valor adic. ao preco básico & 29352225,43 & $-243956,1784$ & $-10132,5022$ & 11561281,35 & $-1714799,925$ \\
\hline
\end{tabular}

\begin{tabular}{|c|c|c|c|c|c|}
\hline \multirow[b]{2}{*}{ cóorGo } & \multicolumn{5}{|c|}{ Descriçąo do Produto Nivel 80} \\
\hline & 06 & 07 & 08 & 10 & 11 \\
\hline PRODUTO & METALÚRGLA & outros & MÁQUINAS E & MATERIAL & EQUIPAMENTOS \\
\hline NIVEL 80 & N FERROSOS & METALÚRGICOS & TRATORES & ELÉTRICO & ELETRÓNICOS \\
\hline Valor da Produçäo & 2732838,406 & 6749555,454 & 18661358,52 & 3995275,414 & 3201380,857 \\
\hline Consumo Intemediário & 3502091,276 & 6201176,189 & 9369443,317 & 4234788,061 & 3309762,118 \\
\hline Valor adic ao preço básico & $-769252,8702$ & 548379,265 & 9291915,201 & $-239512,6477$ & $-108381,2607$ \\
\hline
\end{tabular}

\begin{tabular}{|c|c|c|c|c|c|}
\hline \multirow[b]{2}{*}{ cóoigo } & \multicolumn{5}{|c|}{ Descricáo do Produto Nivel 80} \\
\hline & 12 & 13 & 14 & 15 & 16 \\
\hline PRODUTO & AUTOM.,ÓNIBUS & PEÇAS E OUTROS & MADEIRAE & CELUL, PAPEL & INDÚSTRIA \\
\hline MVEL 80 & E CAMINHÕES & VEICULOS & MOBILIÁRIO & E GRAFICA & DA BORRACHA \\
\hline Valor da Produção & 7236861,465 & 19896852,48 & 14864403,93 & 9093137,368 & 3452515,184 \\
\hline Consumo Intermedianio & 9062497,626 & 7966026,539 & 6855416,968 & 6772797,182 & 2666474,87 \\
\hline Valor adic. ao preco básico & $-1825636,161$ & 11930825,94 & 8008986,958 & 2320340,186 & 786040,3138 \\
\hline
\end{tabular}

\begin{tabular}{|c|c|c|c|c|c|}
\hline \multirow[b]{2}{*}{ COOAGO } & \multicolumn{5}{|c|}{ Descriçąo do Produto Nivel 80} \\
\hline & 17 & 18 & 19 & 20 & 21 \\
\hline PRODUTO & ELEMENTOS & REFINO DO & Quimicos & FARMACÊUTICA & ARTIGOS \\
\hline NNEL 80 & Quimkos & PETRÓLEO & DNERSOS & E VETERINARIA & PLASTICOS \\
\hline Valor da Produção & 3389869,533 & 19480379,71 & 9047208,648 & 4151591,396 & 4039763,132 \\
\hline Consumo Intermediáno & 2640651,928 & 23698806,51 & 7151825,072 & 3254191,797 & 2758520,019 \\
\hline Valor adic. ao preco básico & 749217,6052 & $-4218426,793$ & 1895383,575 & 897399,5989 & 1281243,113 \\
\hline
\end{tabular}

\begin{tabular}{|c|c|c|c|c|c|}
\hline \multirow{4}{*}{$\begin{array}{l}\text { CÓDIGO } \\
\text { PRODUTO } \\
\text { NNEL 80 }\end{array}$} & \multicolumn{5}{|c|}{ Descriçăo do Produto Nivel 80} \\
\hline & 22 & 23 & 24 & 25 & 28 \\
\hline & INDÚSTRIA & ARTIGOS DO & FABRICAÇĀO DE & INDÚSTRIA DO & $\begin{array}{l}\text { BENEFICIAM. } \\
\text { PROD VEGETAIS }\end{array}$ \\
\hline & TEXML & VESTUÁRIO & CALCCADOS & CAFÉ & PROD. VEGETAIS \\
\hline Valor da Produçāo & 9123265,194 & 4286506,961 & 1294992,31 & 6107716,475 & 12532851,31 \\
\hline Consumo Intermediári & 8678410,834 & 3104333,718 & 2018291,328 & 4505517,026 & 6762374,063 \\
\hline Valor adic. ao preço básico & 444854,3593 & 1182173,243 & $-723299,0176$ & 1602199,449 & 5770477,247 \\
\hline
\end{tabular}

\begin{tabular}{|c|c|c|c|c|c|}
\hline \multirow[b]{2}{*}{ COOOHGO } & \multicolumn{5}{|c|}{ Descriçăo do Produto Nivel 80} \\
\hline & 27 & 28 & 29 & 30 & 31 \\
\hline PRODUTO & ABATE DE & INDÚSTRIA DE & FABRICAÇĀO DE & FABRICAÇÃO DE & OUT. PRODUTOS \\
\hline NNEL 80 & ANIMALS & LATCINIOS & AÇÚCAR & ÓLEOS VEGETAIS & AUMENTARES \\
\hline Produçäo & 8760467,816 & 6702299,084 & 2674526,9 & 3914147,91 & 14792260,17 \\
\hline Consumo Intermediár & 6541639,915 & 3908868,925 & 3086269,533 & 5554548,642 & 8964813,005 \\
\hline Valor adic. ao preço básico & 2218827,901 & 2793430,159 & $-411742,6329$ & $-1640400,732$ & 5827447,161 \\
\hline
\end{tabular}


Apêndice 5.1. Continuacão

\begin{tabular}{|c|c|c|c|c|c|}
\hline \multirow[b]{2}{*}{ codfas } & \multicolumn{5}{|c|}{ Descriçăo do Produto Nivel 80} \\
\hline & 32 & 33 & 34 & 35 & 36 \\
\hline PROOUTO & INDÚSTRIAS & & CONSTRUÇÃO & & \\
\hline NIVEL 80 & DIVERSAS & S.I.U.P. & $\mathrm{CML}$ & COMÉRCIO & TRANSPORTES \\
\hline Valor da Produção & 6318466,544 & 10484100,67 & 61498908,89 & 57546088,42 & 31476374,37 \\
\hline Consumo Intermediário & 4460248,448 & 4846436,717 & 38574110,85 & 21452913,58 & 14969144,75 \\
\hline \multirow[t]{2}{*}{ Valor adic. ao preco básico } & $\uparrow 858218,096$ & 5637663,949 & 22924798,04 & 36093174,83 & 16507229,62 \\
\hline & \multicolumn{5}{|c|}{ Descriçåo do Produto Nivel 80} \\
\hline cóosco & 37 & 38 & 38 & 40 & 41 \\
\hline PRODUTO & & INSTITUIÇŌES & SERV. PREST. & SERV. PREST. & ALUGUEL DE \\
\hline NNEL 80 & COMUNICAÇÖES & FINANCEIRAS & A FAMILIA & A EMPRESA & IMÓVEIS \\
\hline Valor da Produçāo & 4282667,894 & 37629888,97 & 42612130,09 & 43111705 & 31043092,9 \\
\hline Consumo Intermediário & 1155881,872 & 7617438,71 & 21185905,19 & 28493365,67 & 4232407,937 \\
\hline \multirow[t]{2}{*}{ Valor adic. ao preço básico } & 3126786,023 & 30012450,26 & 21426224,9 & 14618339,34 & 26810684,97 \\
\hline & \multicolumn{5}{|c|}{ Descriçăo do Produto Nivel 80} \\
\hline COOAGO & 42 & 43 & 46 & & \\
\hline PRODUTO & ADMINISTRAÇÃO & SERV. PRV. & DUMMY & TOTAL & INDÚSTRIA \\
\hline NNEL 80 & PÚBLICA & Ñ MERCANTIS & FINANCEIRO & & \\
\hline Valor da Produçāo & 42262187,32 & 5706368,446 & 0 & 649203413 & 307291152,2 \\
\hline Consumo Intermediário & 11368352,48 & 390417,5125 & 28259311,42 & 375680261,3 & 219665590,2 \\
\hline Valor adic ao preço básico & 30893834,84 & 5315950,934 & $-28259311,42$ & 273523151,7 & 87625561,99 \\
\hline CODKGO & & Descr & çảo do Produlo Ni & el 80 & \\
\hline $\begin{array}{l}\text { PRODUTO } \\
\text { NNEL } 80\end{array}$ & Serviços & Jusante1 & Jusante2 & Jusante3 & \\
\hline Valor da Produçāo & 295670503,41 & 44081879,03 & 73738543,12 & 82861808,31 & \\
\hline Consumo Intermediário & 110865827,70 & 32999870,03 & 48820100,00 & 57498510,84 & \\
\hline Valor adic. ao preco básico & 184804675,71 & 11082009,00 & 24918443,12 & 25363297,48 & \\
\hline
\end{tabular}

Fonte: Dados básicos do IBGE.

Elaborados pela autora. 
Apêndice 5.2. Estimativas a preços constantes do valor adicionado das diferentes atividades produtivas brasileiras, deflacionadas por produto - 1985 .

\begin{tabular}{|c|c|c|c|c|c|}
\hline \multirow{4}{*}{$\begin{array}{l}\text { COOONOO } \\
\text { PROOUTO } \\
\text { NVE: }: 0\end{array}$} & \multicolumn{5}{|c|}{ Deecriçáo do Produto Nivel 80} \\
\hline & 04 & 02 & 03 & 04 & 06 \\
\hline & & EXTRATIVA & PETRÓLEO & MINERAL & \\
\hline & AGROPECUÁRLA & MINERAL & E GÁS & N METÁLICO & SIDERURGIA \\
\hline Valor da Produçáo & 53389472,05 & 2203538,83 & 2820190,235 & 11655928,02 & 14774898,73 \\
\hline Consumo Intermediário & 16176216,73 & 1899276,6 & 1939613,602 & 5537503,28 & 11922280,63 \\
\hline Valor adic. ao preço básico & 37213255,33 & 304262,2301 & 880576,6326 & 6118424,743 & 2852618,105 \\
\hline
\end{tabular}

\begin{tabular}{|c|c|c|c|c|c|}
\hline & \multicolumn{5}{|c|}{ Descriçắo do Produso Nivel 80} \\
\hline & 06 & 07 & 08 & 10 & 11 \\
\hline PRODUTO & METALÚRGIA & OUTROS & MAQQUINASE & MATERIAL & EQUIPAMENTOS \\
\hline NVE 80 & N FERROSOS & METALÚRGICOS & TRATORES & ELETRICO & ELETRÓNICOS \\
\hline Valor da Produçăo & 3877844,889 & 9227945,093 & 15804124,29 & 3954479,594 & 4185581,444 \\
\hline Consumo Intermediári & 3100524,619 & 6229413,948 & 7730601,092 & 3618461,759 & 2923546,476 \\
\hline Valor adic. ao preço bási & 777320,2705 & 2998531,145 & 8073523,196 & 336017,8347 & 1262034,968 \\
\hline
\end{tabular}

\begin{tabular}{|c|c|c|c|c|c|}
\hline \multirow[b]{2}{*}{ COOHEO } & \multicolumn{5}{|c|}{ Descriçáo do Produto Nivel 80} \\
\hline & 12 & 13 & 14 & 15 & 16 \\
\hline PROOUTO & AUTOM.,ONIBI & ÇAS E OUTROS & ADEIRAE & CELUL., PAPEL & INDÚSTRIR \\
\hline NNEL 80 & E CAMINHOES & VEICULOS & MOBILIÁRIO & E GRAFICA & DA BORRACHA \\
\hline Valor da Produçá & 7921769,407 & 14361723,6 & 10217199,44 & 9581967,475 & 3443529,739 \\
\hline Consumo Intermediári & 6732050,398 & 7116323,853 & 4826792,364 & 6412028,79 & 2307097,848 \\
\hline Valor adic. ao preco bási & 1189719.009 & 7245399,749 & 5390407,076 & 3169938,685 & 1136431,891 \\
\hline
\end{tabular}

\begin{tabular}{|c|c|c|c|c|c|}
\hline \multirow{3}{*}{$\begin{array}{l}\text { COOFOO } \\
\text { PROOUTOO }\end{array}$} & \multicolumn{5}{|c|}{ Descriçăo do Produto Nivel 80} \\
\hline & 17 & 18 & 19 & 20 & 21 \\
\hline & ELEMENTOS & REFINO DO & Quimicos & FARMACEUTICA & ARTIGOS \\
\hline NNEL 80 & Quimicos & PETROLLEO & DIVERSOS & E VETERINARIA & PLÁsticos \\
\hline Valor da Producha & 5740534,24 & 23624156,08 & 8149249,595 & 4163966,701 & 3670498,294 \\
\hline Consumo Intermediári & 4819337,991 & 15654786,13 & 4996146,386 & 2807497,861 & 2341889,528 \\
\hline Valor adic. ao preço básico & 921196,2491 & 7969369,947 & 3153103,209 & 1356468,841 & 1328608,766 \\
\hline
\end{tabular}

\begin{tabular}{|c|c|c|c|c|c|}
\hline \multirow{3}{*}{$\begin{array}{l}\text { COOHEO } \\
\text { PROOUTO } \\
\text { NNEL } 80\end{array}$} & \multicolumn{5}{|c|}{ Descriç 10 do Produto Nivel 80} \\
\hline & 22 & 23 & 24 & 25 & 28 \\
\hline & INDÚSTRIA & ARTIGOS DO & FABRICACGAO DE & INDÚSTRIA DO & $\begin{array}{l}\text { BENEFICIAM. } \\
\text { PROD YEGETAS }\end{array}$ \\
\hline Valor da Produçá & 8968765,955 & 5770466,841 & 2538758,31 & 6541178,886 & 11760788,3 \\
\hline Consumo Intermediário & 7607154,473 & 3108769,871 & 2452750,801 & 5655398,607 & 7842358,586 \\
\hline Valor adic ao preço básico & 1361611,482 & 2661696,97 & 86007,50881 & 885780,2787 & 3918429,713 \\
\hline
\end{tabular}

\begin{tabular}{|c|c|c|c|c|c|}
\hline \multirow[b]{2}{*}{ Cóoloo } & \multicolumn{5}{|c|}{ Descriço do Produto Nivel 80} \\
\hline & 27 & 28 & 29 & 30 & 31 \\
\hline PROOUTO & ABATE DE & INDÚSTRIA DE & FABRICAÇARO DE & FABRICAÇAO DE & OUT.PRODUTOS \\
\hline NVEL 80 & ANIMANS & LATICINIOS & ACUUCAR & ÓLEOS VEGETAIS & ALIMENTARES \\
\hline Valor da Produçá & 8452166,046 & 5553795,552 & 2306435,808 & 4265454,424 & 11959520,28 \\
\hline Consumo Intermediário & 6594856,589 & 3449989,594 & 2836151,697 & 5748343,037 & 8550642,953 \\
\hline Valor adic. ao preco básico & 1857309,456 & 2103805,959 & $-529715,8888$ & $-1482888,613$ & 3408877,325 \\
\hline
\end{tabular}


Apêndice 5.2. Continuação

\begin{tabular}{|c|c|c|c|c|c|}
\hline \multirow[b]{2}{*}{ coblao } & \multicolumn{5}{|c|}{ Descriçáo do Produto Nivel 80} \\
\hline & 32 & 33 & 34 & 35 & 36 \\
\hline PRODUTO & INDUSTRIAS & & CONSTRUGAAO & & \\
\hline NVEL 80 & OIVERSAS & S.I.U.P. & CIVIL & COMÉRCIO & TRANSPORTES \\
\hline Valor da Produçao & 3999295,006 & 12306456,77 & 54651776,34 & 56219620,16 & 30314229,46 \\
\hline Consumo Intermediário & 1910215,356 & 6158306,074 & 26557867,69 & 16134329,55 & 13158155,22 \\
\hline \multirow[t]{2}{*}{ Valor adic ao preco bassico } & 2089079.65 & 6148150,699 & 28093908,65 & 40085290,61 & 17156074,24 \\
\hline & \multicolumn{5}{|c|}{ Descriçáo do Produto Nivel 80} \\
\hline COOHGO & 37 & 38 & 39 & 40 & 41 \\
\hline PROOUTO & & INSTITUIÇÖES & SERV. PREST. & SERV. PREST. & ALUGUEL DE \\
\hline NNEL 80 & COMUNICAÇÓES & FINANCEIRAS & A FAMILIA & A EMPRESA & IMÓVEIS \\
\hline Valor da Produço & 4656235,221 & 6 & 34418807,05 & 17801328,62 & 14920578,06 \\
\hline Consumo Intermediário & 914952.9087 & 8595643,432 & 17074987,74 & 3276387,482 & 2401015,906 \\
\hline \multirow[t]{2}{*}{ Valor adic. ao preço bassico } & 3741282,312 & 48256988,02 & 17343819,31 & 14524941,13 & 12519562,15 \\
\hline & \multicolumn{5}{|c|}{ Descriçáo do Produto Nivel 80} \\
\hline cob160 & 42 & 43 & 46 & & \\
\hline PROOUTO & ADMINISTRAÇĀO & SERV.PRIV. & DUMMY & TOTAL & INDÚSTRIA \\
\hline NNEL 80 & PÚBLICA & N MERCANTIS & FINANCEIRO & & \\
\hline Valor da Produçá & 51733563,36 & 3407617,068 & 0 & 622168066,7 & 298453984,2 \\
\hline Consumo Intermediário & 15489421,2 & 353259,2851 & 46019410,44 & 330981758,4 & 191387978,5 \\
\hline Valor adic. ao preco básico & 36244142,16 & 3054357,783 & $-46019410,44$ & 291186308,3 & 107066005.7 \\
\hline COOAGO & \multicolumn{5}{|c|}{ Descriçăo do Produto Nivel 80} \\
\hline PRODUTO & Serviços & Jusanto1 & Jusante2 & Jusante3 & \\
\hline \multicolumn{6}{|l|}{ NIVEC 80} \\
\hline Valor da Produçáo & 270324610,4 & 44620353,26 & 66797072,97 & 75765838,93 & \\
\hline Consumo Intermediário & 77398152,72 & 36946436,1 & 50323871,42 & 57931025,89 & \\
\hline Valor adic. ao preco básico & 192926457.7 & 7673917,154 & 16473201,56 & 17834813.04 & \\
\hline
\end{tabular}

Fonte: Dados bésicos do IBGE.

Elaborados pela autora. 
Apêndice 5.3. Estimativas a preços constantes do valor adicionado das diferentes atividades produtivas brasileiras, deflacionadas por produto - 1990 .

\begin{tabular}{|c|c|c|c|c|c|}
\hline \multirow{4}{*}{$\begin{array}{l}\text { COOOHO } \\
\text { PROOUTO }\end{array}$} & \multicolumn{5}{|c|}{ Descricáo do Produto Nivel 80} \\
\hline & 01 & 02 & 03 & 04 & 05 \\
\hline & & EXTRATIVA & PETRÓLEO & MINERAL & \\
\hline & AGROPECUARIA & MINERAL & EGAS & N METÁLICO & SIDERURGIA \\
\hline Valor da Produção & 48400991,79 & 3843503,137 & 4682929,623 & 9837549,834 & 14536355,04 \\
\hline Consumo Intermediàio & 18564882,42 & 2198680,924 & 2095708,11 & 5858125,782 & 11167343,09 \\
\hline Valor adic. ao preco básico & 29836109.37 & 1644822,212 & 2587221.513 & 3979424,053 & 3369011,952 \\
\hline
\end{tabular}

\begin{tabular}{|c|c|c|c|c|c|}
\hline & \multicolumn{5}{|c|}{ Descriçăo do Produto Nivel 80} \\
\hline & 06 & 07 & 08 & 10 & 11 \\
\hline PRODUTO & METALÚRGLA & OUTROS & MÁQUINAS E & MATERIAL & EQUIPAMENTOS \\
\hline NIVEL 80 & N FERROSOS & METALÚRGICOS & TRATORES & ELÉTRICO & ELETRÓNICOS \\
\hline Pmoducá & 4600554,934 & 11367738,83 & 12501 & 4168770,951 & 4492328,83 \\
\hline onst & 3895605.735 & 7419184,643 & 744174 & 4243359,943 & 3597947,193 \\
\hline Valor adic. ao preco básico & 704949.1985 & 3948554,19 & 5059399,559 & $-74588,9918$ & 894381,6372 \\
\hline
\end{tabular}

\begin{tabular}{|c|c|c|c|c|c|}
\hline \multirow{4}{*}{$\begin{array}{l}\text { CODIGO } \\
\text { PROOUTO } \\
\text { NNEL } 80\end{array}$} & \multicolumn{5}{|c|}{ Descriç30 do Produto Nivel 80} \\
\hline & 12 & 13 & 14 & 15 & 16 \\
\hline & AUTOM.,ÓNIBUS & 'EÇAS E OUTROS & MADEIRAE & CELUUL, PAPEL. & INDÚSTRIA \\
\hline & E CAMINHÓES & VEICULLS & MOBILLARIO & E GRAFICA & DABORRACHA \\
\hline Smd & 647 & 8564958,565 & 61928 & 339 & 5252949,906 \\
\hline Cor & & 640 & 461 & 743 & 306 \\
\hline alor adic ao preco bási & 1058973,562 & 2162963,576 & 1580825,41 & 2208759,454 & 2190895,788 \\
\hline
\end{tabular}

\begin{tabular}{|c|c|c|c|c|c|}
\hline \multirow{4}{*}{$\begin{array}{l}\text { COOHGO } \\
\text { PRODUTOO } \\
\text { NIVEL } 80\end{array}$} & \multicolumn{5}{|c|}{ Descriçăo do Produto Nivel 80} \\
\hline & 17 & 18 & 19 & 20 & 21 \\
\hline & ELEMENTOS & REFINO DO & QUIMICOS & FARMACÊUTICA & ARTIGOS \\
\hline & QUIMICOS & PETRÓLEO & DNERSOS & E VETERINARIA & PLÁSTICOS \\
\hline Valor da Produção & 6473019,022 & 27257063,09 & 8913847,391 & 5176379,45 & 4965725,073 \\
\hline Consumo Intermedi & 4962440,744 & 19187010,07 & 5939909,749 & 3290154,324 & 2864953,908 \\
\hline Valor adic. ao preço básico & 1510578,277 & 8070053,02 & 2973937,641 & 1886225,126 & 2100771,165 \\
\hline
\end{tabular}

\begin{tabular}{|c|c|c|c|c|c|}
\hline \multirow{4}{*}{$\begin{array}{l}\text { COOLGO } \\
\text { PROOUTO } \\
\text { NREL } 80\end{array}$} & \multicolumn{5}{|c|}{ Descriçāo do Produto Nivel 80} \\
\hline & 22 & 23 & 24 & 25 & 26 \\
\hline & INDÚSTRIA & ARTIGOS DO & FABRICAÇÃO DE & INDÚSTRIA DO & BENEFICLAM. \\
\hline & TEXTL & VESTUARIO & CALÇADOS & CAFE & PROD. VEGETAIS \\
\hline Valor da Produção & 10295234,61 & 3523171,886 & 3586486,123 & 2593912,257 & 9981494,577 \\
\hline Consumo Intermedi & 8248068,946 & 3685416,431 & 2982676,859 & 2274535,503 & 8191281,774 \\
\hline Valor adic. ao preço básico & 2047165,668 & $-162244,5444$ & 603809,2638 & 319376,7547 & 1790212,803 \\
\hline
\end{tabular}

\begin{tabular}{|c|c|c|c|c|c|}
\hline \multirow{4}{*}{$\begin{array}{l}\text { CÓOHGO } \\
\text { PROOUTO } \\
\text { NIVEL BO }\end{array}$} & \multicolumn{5}{|c|}{ Descriçăo do Produto Nivel 80} \\
\hline & 27 & 28 & 29 & 30 & 31 \\
\hline & ABATE DE & INDÚSTRIA DE & FABRICAÇĀO DE & FABRICAÇĀO DE & OUT. PRODUTOS \\
\hline & ANIMAIS & LATICINIOS & AÇÚCAR & OLEOS VEGETAIS & ALUMENTARES \\
\hline Produçã & 9419389,625 & 5363525,266 & 2673969,368 & 5589970,315 & 13952027,96 \\
\hline Consumo Intermediánio & 7636545,508 & 3791655,355 & 2318147,659 & 5151340,796 & 9558414,811 \\
\hline Valor adic. ao preço básico & 1782844,117 & 1571869,911 & 355821,7092 & 438629,5183 & 4393613,147 \\
\hline
\end{tabular}


Apêndice 5.3. Continuação

\begin{tabular}{|c|c|c|c|c|c|}
\hline \multirow[b]{2}{*}{ códGo } & \multicolumn{5}{|c|}{ Descriçăo do Produto Nivel 80} \\
\hline & 32 & 33 & 34 & 35 & \multirow{3}{*}{$\begin{array}{c}36 \\
\text { TRANSPORTES }\end{array}$} \\
\hline PRODUTO & INDÚSTRIAS & \multicolumn{3}{|c|}{ CONSTRUÇÃO } & \\
\hline NNEL 80 & OIVERSAS & S.I.U.P. & CML & COMÉRCIO & \\
\hline Valor da Produção & 3820348,903 & 15620230,23 & 52873140,38 & 53025532,53 & 26067272,63 \\
\hline Consumo intermediário & 2137985,523 & 8020402,04 & 25343278,52 & 18778713,44 & 12973245,92 \\
\hline \multirow[t]{2}{*}{ Valor adic. ao preco básico } & 1682363,38 & 7599828,187 & 27529861,86 & 34246819,09 & 13094026,71 \\
\hline & \multicolumn{5}{|c|}{ Descriçäo do Produto Nivel 80} \\
\hline CÓDIGO & 37 & 38 & 39 & 40 & 41 \\
\hline PRODUTO & & INSTITUIÇŌES & SERV. PREST. & SERV. PREST. & ALUGUEL DE \\
\hline NIVEL 80 & COMUNICAÇÕES & FINANCEIRAS & A FAMILIA & A EMPRESA & IMÓVEIS \\
\hline Valor da Produçảo & 5455657,199 & 63263286,57 & 39259899,3 & 14729263,93 & 21931451,3 \\
\hline Consumo Intermediário & 1043954,502 & 8598946,27 & 18028434,96 & 3714848,995 & 2135323,311 \\
\hline \multirow[t]{2}{*}{ Valor adic. ao preco básico } & 4411702,697 & 54664340,3 & 21231464,34 & 11014414,94 & 19796127,98 \\
\hline & \multicolumn{5}{|c|}{ Descriçăo do Produto Nivel 80} \\
\hline Código & 42 & 43 & 46 & & \\
\hline PRODUTO & ADMINISTRAÇÃO & SERV. PRIV. & DUMMY & TOTAL & INDÚSTRIA \\
\hline NIVEL 80 & PÚBLICA & N MERCANTIS & FINANCEIRO & & \\
\hline Valor da Produçāo & 77522612,96 & 4013302,943 & 0 & 651911672,2 & 298242401,1 \\
\hline Consumo Intermediário & 19736943,68 & 340419,3782 & 52790405,94 & 357138209,8 & 200432091 \\
\hline Valor adic. ao preco básico & 57785669,28 & 3672883,565 & $-52790405,94$ & 294773462,4 & 97810310,12 \\
\hline CÓDIGO & \multicolumn{5}{|c|}{ Descriçăo do Produto Nivel 80} \\
\hline PRODUTO & Serviços & Jusante1 & Jusante2 & Jusante3 & \\
\hline \multicolumn{6}{|l|}{ NIVEL 80} \\
\hline Valor da Produção & 305268279,36 & 42095280,43 & 62240137,02 & 72535371,64 & \\
\hline Consumo Intermediário & 85350830,45 & 34325947,34 & 48496365,37 & 56744434,32 & \\
\hline Valor adic. ao preco básico & 219917448,90 & 7769333,09 & 13743771,65 & 15790937,32 & \\
\hline
\end{tabular}

Fonte: Dados básicos do IBGE.

Elaborados pela autora. 
Apêndice 5.4. Estimativas a preços constantes do valor adicionado das diferentes atividades produtivas brasileiras, deflacionadas por produto- 1991.

\begin{tabular}{|c|c|c|c|c|c|}
\hline \multirow[b]{2}{*}{ CODIGO } & \multicolumn{5}{|c|}{ Descriçăo do Produto Nivel 80} \\
\hline & 01 & 02 & 03 & 04 & 05 \\
\hline PRODUTO & & EXTRATIVA & PETRÓLEO & MINERAL & \\
\hline NNEL 80 & AGROPECUARIA & MINERAL & E GÁS & N̂ METÁLICO & SIDERURGIA \\
\hline Valor da Produção & 47513997,52 & 4247391,908 & 4095452,35 & 10214444,28 & 15131818,2 \\
\hline Consumo Intermediário & 17707642,07 & 2124428,797 & 1920794,53 & 5672281,257 & 11091396,48 \\
\hline \multirow[t]{2}{*}{ Valor adic. ao preco básico } & 29806355,45 & 2122963,11 & 2174657,82 & 4542163,027 & 4040421,715 \\
\hline & \multicolumn{5}{|c|}{ Descriçăo do Produto Nivel 80} \\
\hline CÓDIGO & 06 & 07 & 08 & 10 & 11 \\
\hline PRODUTO & METALÚRGIA & OUTROS & MÁQUINAS E & MATERIAL & EQUIPAMENTOS \\
\hline NINEL 80 & NFERROSOS & METALÚRGICOS & TRATORES & ELETRICO & ELETRÓNICOS \\
\hline Valor da Produção & 4563373,052 & 11508860,58 & 12343385,69 & 4800381,638 & 5073615,585 \\
\hline Consumo Intermediário & 3690604,698 & 7147181,652 & 6459017,381 & 4011456,692 & 3551118,591 \\
\hline Valor adic. ao preço básico & 872768,3534 & 4361678,924 & 5884368,304 & 788924,9458 & 1522496,993 \\
\hline
\end{tabular}

\begin{tabular}{|c|c|c|c|c|c|}
\hline \multirow[b]{2}{*}{ CóDIGo } & \multicolumn{5}{|c|}{ Descriçáo do Produto Nivel 80} \\
\hline & 12 & 13 & 14 & 15 & 16 \\
\hline PRODUTO & AUTOM.,ÓNIBUS & EÇAS E OUTROS & MADEIRAE & CELUL., PAPEL & INDÚSTRIA \\
\hline NIVEL 80 & E CAMINHÖES & VEICULOS & MOBILLÁRIO & E GRÁFICA & DA BORRACHA \\
\hline Valor da Produção & 6794415,064 & 8427645,973 & 6441207,647 & 10900482,91 & 5235091,373 \\
\hline Consumo Intermediário & 5405108,392 & 5834459,302 & 3970692,243 & 7652922,99 & 3003879,372 \\
\hline Valor adic. ao preço básico & 1389306,672 & 2593186,671 & 2470515,404 & 3247559,916 & 2231212 \\
\hline
\end{tabular}

\begin{tabular}{|c|c|c|c|c|c|}
\hline \multirow{4}{*}{$\begin{array}{l}\text { CÓDIGO } \\
\text { PRODUTO } \\
\text { NNEL } 80\end{array}$} & \multicolumn{5}{|c|}{ Descriçăo do Produto Nivel 80} \\
\hline & 17 & 18 & 19 & 20 & 21 \\
\hline & ELEMENTOS & REFINO DO & QUIMIcos & FARMACĖUTICA & ARTIGOS \\
\hline & QUIMICOS & PETRÓLEO & DIVERSOS & E VETERINÁRLA & PLASTICOS \\
\hline Valor da Produção & 7508897,583 & 25570113,84 & 9147008,141 & 4791350,284 & 4681874,577 \\
\hline Consumo Intermediário & 5388400,074 & 18491746,58 & 6018794,162 & 3258832,528 & 2848090,038 \\
\hline Valor adic. ao preço básico & 2120497,51 & 7078367,262 & 3128213,979 & 1532517,756 & 1833784,539 \\
\hline
\end{tabular}

\begin{tabular}{|c|c|c|c|c|c|}
\hline \multirow{3}{*}{$\begin{array}{l}\text { CODIGO } \\
\text { PRODUTO }\end{array}$} & \multicolumn{5}{|c|}{ Descriçăo do Produto Nivel 80} \\
\hline & 22 & 23 & 24 & 25 & 28 \\
\hline & INDÚSTRIA & ARTIGOS DO & FABRICAÇĀO DE & INDÚSTRIA DO & BENEFICIAM. \\
\hline NIVEL 80 & TEXTIL & VESTUARIO & CALÇADOS & CAFÉ & PROD. VEGETAIS \\
\hline Jrodução & 10989358,7 & 3606746,659 & 3908337,247 & 2477938,441 & 9376201,899 \\
\hline $10 \mathrm{ln}$ & 8507371,064 & 3468900,97 & 2765747,416 & 2178389,181 & 7604487,208 \\
\hline Valor adic. ao preço básico & 2481987,635 & 137845,6899 & 1142589,831 & 299549,2598 & 1771714,691 \\
\hline
\end{tabular}

\begin{tabular}{|c|c|c|c|c|c|}
\hline \multirow{4}{*}{$\begin{array}{l}\text { CÓDIGO } \\
\text { PRODUTO } \\
\text { NIVEL } 80\end{array}$} & \multicolumn{5}{|c|}{ Descriçāo do Produto Nivel 80} \\
\hline & 27 & 28 & 28 & 30 & 31 \\
\hline & ABATE DE & INDÚSTRIA DE & FABRICAÇÃO DE & FABRICAÇẢO DE & OUT. PRODUTOS \\
\hline & ANIMAIS & LATICINIOS & AÇÚCAR & ÓLEOS VEGETAIS & ALIMENTARES \\
\hline Valor da Produçāo & 9705908,451 & 4973423,735 & $\overline{3114005, \overline{129}}$ & 5291056,894 & 13457878,22 \\
\hline Consumo Intermediáni & 8157657,025 & 3912221,51 & 2653071,678 & 4917024,325 & 9861112,561 \\
\hline Valor adic. ao preço básico & 1548251,426 & 1061202,225 & 460933,4506 & 374032,569 & 3596765,661 \\
\hline
\end{tabular}


Apêndice 5.4. Continuação

\begin{tabular}{|c|c|c|c|c|c|}
\hline \multirow[b]{2}{*}{ cóotGo } & \multicolumn{5}{|c|}{ Descriçäo do Produto Nivel 80} \\
\hline & 32 & 33 & 34 & 35 & 36 \\
\hline PRODUTO & INDÚSTRIAS & \multicolumn{3}{|c|}{ CONSTRUÇÃO } & \multirow{2}{*}{ TRANSPORTES } \\
\hline NIVEL 80 & DNERSAS & S.I.U.P. & $\mathrm{CML}$ & COMÉRCIO & \\
\hline Valor da Produçāo & 4060767,844 & 17757931,01 & 51253065,62 & 49084293,56 & 23959499,52 \\
\hline Consumo Intermediário & 2093046,035 & 10276301,9 & 24374377,52 & 17388783,78 & 11705829,2 \\
\hline \multirow[t]{2}{*}{ Valor adic. ao preço básico } & 1967721,808 & 7481629,112 & 26878688,1 & 31695509,78 & 12253670,32 \\
\hline & \multicolumn{5}{|c|}{ Descriçāo do Produto Nivel 80} \\
\hline código & 37 & 38 & 39 & 40 & 41 \\
\hline PRODUTO & & INSTITUIÇŐES & SERV. PREST. & SERV. PREST. & ALUGUEL DE \\
\hline NNEL 80 & COMUNICAÇŌES & FINANCEIRAS & A FAMILIA & A EMPRESA & IMÓVEIS \\
\hline Valor da Produção & 5469719,084 & 53084914,77 & 39515162,22 & 17267104,17 & 42747766,18 \\
\hline Consumo Intermediario & 1625529,42 & 8451093,16 & 17842167,06 & 3850701,295 & 2032493,876 \\
\hline \multirow[t]{2}{*}{ Valor adic ao preco básico } & 3844189,665 & 44633821,62 & 21672995,15 & 13416402,87 & 40715272,31 \\
\hline & \multicolumn{5}{|c|}{ Descriçăo do Produto Nivel 80} \\
\hline CODDIGO & 42 & 43 & 46 & & \\
\hline PRODUTO & ADMINISTRAÇĀO & SERV. PRIV. & DUMMY & TOTAL & INDÚSTRIA \\
\hline NNEL 80 & PÚBLICA & N MERCANTIS & FINANCEIRO & & \\
\hline Valor da Produçāo & 69775265,77 & 4099916,566 & 0 & 653967069,9 & 301449430,5 \\
\hline Consumo Intermediário & 20307451,61 & 338463,1801 & 41122185,85 & 340683254,7 & 198310914,2 \\
\hline Valor adic. ao preco básico & 49467814,16 & 3761453,386 & $-41122185,85$ & 313283815,2 & 103138516,4 \\
\hline COODIGO & \multicolumn{5}{|c|}{ Descriçāo do Produto Nivel 80} \\
\hline PRODUTO & Serviços & Jusante1 & Jusante2 & Jusante 3 & \\
\hline \multicolumn{6}{|l|}{ NIVEL 80} \\
\hline Valor da Produçáo & 305003641,84 & 42447432,13 & 62346518,00 & 73335876,70 & \\
\hline Consumo Intermediário & 83542512,59 & 34811251,00 & 48643055,81 & 57150426,87 & \\
\hline Valor adic. ao preco básico & 221461129,25 & 7636181,13 & 13703462,20 & 16185449,83 & \\
\hline
\end{tabular}

Fonte: Dados básicos do IBGE.

Elaborados pela autora. 
Apêndice 5.5. Estimativas a preços constantes do valor adicionado das diferentes atividades produtivas brasileiras, deflacionadas por produto - 1992.

\begin{tabular}{|c|c|c|c|c|c|}
\hline \multirow{4}{*}{$\begin{array}{l}\text { COOISO } \\
\text { PRODUTO } \\
\text { NNEL } 80\end{array}$} & \multicolumn{5}{|c|}{ Descriçăo do Produto Nivel 80} \\
\hline & 04 & 02 & 03 & 04 & 05 \\
\hline & & EXTRATIVA & PETRÓLEO & MINERAL & \\
\hline & AGROPECUARIA & MINERAL & EGÁS & Ñ METÁLICO & SIDERURGIA \\
\hline Valor da Produçāo & 48203402,5 & 3788833,416 & 3549323,949 & 8345164,245 & 14660851,5 \\
\hline Consumo Intermediário & 18467143,35 & 2055480,937 & 2013017,881 & 4964887,874 & 10985010,59 \\
\hline \multirow[t]{2}{*}{ Valor adic. ao preço básico } & 29736259.15 & 1733352,479 & 1536306,068 & 3380276,371 & 3675840,909 \\
\hline & \multicolumn{5}{|c|}{ Descriçăo do Produto Nivel 80} \\
\hline COODGO & 06 & 07 & 08 & 10 & 11 \\
\hline PRODUTO & METALÚRGIA & OUTROS & MAQUINAS E & MATERIAL & EQUIPAMENTOS \\
\hline NNEL 80 & Ñ FERROSOS & METALÚRGICOS & TRATORES & ELÉTRICO & ELETRÓNICOS \\
\hline Valor da Produçāo & 4594578,357 & 10002036,38 & 12389580,52 & 5026651,236 & 4163777,984 \\
\hline Consumo Intermediário & 3502968,64 & 6629553,715 & 5991831,914 & 3831565,186 & 2778627,322 \\
\hline Valor adic. ao preço básico & 1091609,716 & 3372482.665 & 6397748,601 & 1195086,05 & 1385150,662 \\
\hline
\end{tabular}

\begin{tabular}{|c|c|c|c|c|c|}
\hline \multirow{4}{*}{$\begin{array}{l}\text { COOOHGO } \\
\text { PRODUTO } \\
\text { NNEL } 80\end{array}$} & \multicolumn{5}{|c|}{ Descriçăo do Produto Nivel 80} \\
\hline & 12 & 13 & 14 & 15 & 18 \\
\hline & AUTOM.,ÓNIBUS & PEÇAS E OUTROS & MADEIRAE & CELUL, PAPEL & INDÚSTRIA \\
\hline & E CAMINHÓES & VEICULOS & MOBILLÁRIO & E GRÁFICA & DA BORRACHA \\
\hline Valor da Produçāo & 6108306,943 & 8527246,466 & 5858488,476 & 9188892,228 & 3843990,052 \\
\hline Consumo Interm & 5019947,9 & 5526166,813 & 3714058,612 & 7026557,731 & 2524848,45 \\
\hline Valor adic. ao preço básico & 1088359,043 & 3001079,653 & 2144429,864 & 2162334,497 & 1319141,601 \\
\hline
\end{tabular}

\begin{tabular}{|c|c|c|c|c|c|}
\hline \multirow{4}{*}{$\begin{array}{l}\text { COODIGO } \\
\text { PRODUTO } \\
\text { NIVEL } 80\end{array}$} & \multicolumn{5}{|c|}{ Descriçăo do Produto Nivel 80} \\
\hline & 17 & 18 & 19 & 20 & 21 \\
\hline & ELEMENTOS & REFINO DO & QuIMICOS & FARMACÊUTICA & ARTIGOS \\
\hline & Quimicos & PETRÓLEO & DIVERSOS & E VETERINÁRIA & PLÁstICOS \\
\hline Valor da Produção & 6904552,464 & 26053524,52 & 7962499,657 & 5056292,147 & 3919001,483 \\
\hline Consumo Intermediário & 5133263,33 & 16911136,75 & 5588236,478 & 3012839,178 & 2430812,434 \\
\hline Valor adic. ao preço básico & 1771289,133 & 9142387,764 & 2374263,179 & 2043452,969 & 1488189,049 \\
\hline
\end{tabular}

\begin{tabular}{|c|c|c|c|c|c|}
\hline \multirow{3}{*}{$\begin{array}{l}\text { CÓDIGO } \\
\text { PRODUTO }\end{array}$} & \multicolumn{5}{|c|}{ Descriçåo do Produto Nivel 80} \\
\hline & 22 & 23 & 24 & 25 & 28 \\
\hline & INDÚSTRIA & ARTIGOS DO & FABRICAÇÃO DE & INDÚSTRIA DO & $\begin{array}{l}\text { BENEFICIAM. } \\
\text { ROD. VEGETAIS }\end{array}$ \\
\hline Valor da Produc & 10314012,29 & 4376825,667 & 4237283,551 & 2293201,96 & 9657666,97 \\
\hline Consumo Intermediário & 7635593,071 & 3116746,219 & 2451009,157 & 2033036,055 & 7671248,642 \\
\hline Valor adic. ao preço básico & 2678419,214 & 1260079,448 & 1786274,393 & 260165,9053 & 1986418,328 \\
\hline
\end{tabular}

\begin{tabular}{|c|c|c|c|c|c|}
\hline \multirow[b]{2}{*}{ COODIGO } & \multicolumn{5}{|c|}{ Descriçăo do Produto Nivel 80} \\
\hline & 27 & 28 & 29 & 30 & 31 \\
\hline PRODUTO & ABATE DE & INDÚSTRLA DE & FABRICAÇÃO DE & FABRICAÇÃO DE & OUT. PRODUTOS \\
\hline NIVEL 80 & ANIMAIS & LATICINIOS & AÇÚCAR & OLEOS VEGETAIS & ALMENTARES \\
\hline Valor da Produçāo & 10447781,55 & 5019275,121 & 3212851,994 & 5529797,811 & 12181985,61 \\
\hline Consumo Intermediário & 8520705,57 & 3855653,539 & 2880138,966 & 5274347,293 & 8728038,98 \\
\hline Valor adic. ao preco básico & 1927075,984 & 1163621,582 & 332713,0284 & 255450,5184 & 3453946,625 \\
\hline
\end{tabular}


Apêndice 5.5. Continuação.

\begin{tabular}{|c|c|c|c|c|c|}
\hline \multirow[b]{2}{*}{ cóo:Go } & \multicolumn{5}{|c|}{ Descriça do do Produto Nivel 80} \\
\hline & 32 & 33 & 34 & 35 & 36 \\
\hline PRODUTO & INDÚSTRIAS & & CONSTRUÇÃO & & \\
\hline MNEL 80 & ONERSAS & S.I.U.P. & $\mathrm{CML}$ & COMÉRCIO & TRANSPORTES \\
\hline Valor da Produçáo & 3792216,308 & 19871988,86 & 47388571,93 & 47352632,41 & 24862329,62 \\
\hline Consumo Intermediário & 2008408,143 & 10780590,67 & 20751344,92 & 18122681,18 & 12024009,62 \\
\hline \multirow[t]{2}{*}{ Valor adic. ao preço básico } & 1783808,164 & 9091398,19 & 26637227,02 & 29229951,23 & 12838320,01 \\
\hline & \multicolumn{5}{|c|}{ Descriçåo do Produto Nivel 80} \\
\hline CóDiGo & 37 & 38 & 39 & 40 & 41 \\
\hline PRODUTO & & INSTITUIÇŌES & SERV. PREST. & SERV. PREST. & ALUGUEL DE \\
\hline NNEL 80 & COMUNICAÇǑES & FINANCEIRAS & A FAMILIA & A EMPRESA & IMÓVEIS \\
\hline Vaior da Produçào & 6339832,858 & 88861779,34 & 40180548,74 & 17581807,09 & 34085684,36 \\
\hline Consumo Intermediàrio & 1324705,108 & 9082146,68 & 16874241,22 & 4079909,309 & 1971462,967 \\
\hline Valor adic. ao preco básico & 5015127,75 & 79779632,66 & 23306307,52 & 13501897,78 & 32114221,39 \\
\hline
\end{tabular}

\begin{tabular}{|c|c|c|c|c|c|}
\hline \multirow[b]{2}{*}{ CÓDIGO } & \multicolumn{5}{|c|}{ Descriç5̄o do Produto Nivel 80} \\
\hline & 42 & 43 & 46 & & \\
\hline PRODUTO & ADMINISTRAÇĀO & SERV. PRIV. & DUMMY & TOTAL & INDÚSTRIA \\
\hline NIVEL 80 & PÚBLICA & N MERCANTIS & FINANCEIRO & & \\
\hline Valor da Produçāo & 64968854,36 & 4314214,873 & 0 & 665018137,8 & 288267051,6 \\
\hline Consumo Intermediánio & 19017605,69 & 344355,4834 & 74705677,86 & 361361611,4 & 185347673 \\
\hline Valor adic ao preco básico & 45951248,66 & 3969859,39 & $-74705677,86$ & 303656526,4 & 102919378,7 \\
\hline
\end{tabular}

\begin{tabular}{|c|c|c|c|c|}
\hline \multirow{2}{*}{$\begin{array}{l}\text { COODIGO } \\
\text { PRODUTO } \\
\text { NNEL } 80\end{array}$} & \multicolumn{4}{|c|}{ Descriçăo do Produto Nivel 80} \\
\hline & Serviços & Jusante1 & Jusante2 & Jusante3 \\
\hline Valor da Produção & 328547683,65 & 43065127,87 & 61105601,96 & 71419614,24 \\
\hline Consumo Intermediàrio & 82841117,25 & 35368393,39 & 47810490,99 & 55446084,06 \\
\hline Valor adic. ao preco básico & 245706566,39 & 7696734,48 & 13295110,97 & 15973530,18 \\
\hline
\end{tabular}

Fonte: Dados básicos do IBGE.

Elaborados pela autora. 
Apêndice 5.6. Estimativas a preços constantes do valor adicionado das diferentes atividades produtivas brasileiras, deflacionadas por produto-1993.

\begin{tabular}{|c|c|c|c|c|c|}
\hline \multirow[b]{2}{*}{ código } & \multicolumn{5}{|c|}{ Descriçäo do Produto Nivel 80} \\
\hline & 01 & 02 & 03 & 04 & 05 \\
\hline PRODUTO & & EXTRATIVA & PETRÓLEO & MINERAL & \\
\hline NIVEL 80 & AGROPECUARIA & MINERAL & E GAS & N METALICO & SIDERURGIA \\
\hline Valor da Produção & 45036788,17 & 3058838,897 & 2534615,958 & 8594795,439 & 14195926,52 \\
\hline Consumo Intermediánio & 18310603,42 & 1969856,837 & 1923149,809 & 4869702,332 & 10512751,52 \\
\hline Valor adic. ao preço básico & 26726184,75 & 1088982,06 & 611466,149 & 3725093,108 & 3683174,997 \\
\hline
\end{tabular}

\begin{tabular}{|c|c|c|c|c|c|}
\hline \multirow[b]{2}{*}{ CODIGO } & \multicolumn{5}{|c|}{ Descriçäo do Produto Nivel 80} \\
\hline & 08 & 07 & 08 & 10 & 11 \\
\hline PRODUTO & METALÚRGIA & OUTROS & MÁQUINAS E & MATERIAL & EQUIPAMENTOS \\
\hline NIVEL 80 & $\bar{N}$ FERROSOS & METALURGICOS & TRATORES & ELETRICO & ELETRÓNICOS \\
\hline Valor da Produção & 5028561,414 & 10914173,66 & 13746187,66 & 5891626,332 & 5378688,084 \\
\hline Consumo Intermediário & 3577508,319 & 6761698,697 & 5720892,475 & 4262481,294 & 3361918,462 \\
\hline Valor adic ao preco básico & 1451053,095 & 4152474,961 & 8025295,188 & 1629145,038 & 2016769,622 \\
\hline
\end{tabular}

\begin{tabular}{|c|c|c|c|c|c|}
\hline \multirow[b]{2}{*}{ CÓDIGO } & \multicolumn{5}{|c|}{ Descricáo do Produto Nivet 80} \\
\hline & 12 & 13 & 14 & 15 & 16 \\
\hline PRODUTO & AUTOM.,ÓNIBUS & PEÇAS E OUTROS & MADEIRA E & CELUL, PAPEL & INDÚSTRIA \\
\hline NNEL 80 & E CAMINHÓES & VEICULOS & MOBILLÁRIO & E GRÁFICA & DABORRACHA \\
\hline Valor da Producão & 7633573,201 & 9762690,665 & 6632155,982 & 9092883,484 & 3835844,069 \\
\hline Consumo Intern & 5809772 & 6365646,479 & 3931230,784 & 7080813,666 & 2504754,985 \\
\hline Valor adic. ao preço básico & 1823800,357 & 3397044,185 & 2700925,198 & 2012069,819 & 1331089,083 \\
\hline
\end{tabular}

\begin{tabular}{|c|c|c|c|c|c|}
\hline \multirow{4}{*}{$\begin{array}{l}\text { CODDIGO } \\
\text { PRODUTO } \\
\text { NIELL } 80\end{array}$} & \multicolumn{5}{|c|}{ Descriçăo do Produto Nivel 80} \\
\hline & 17 & 18 & 19 & 20 & 21 \\
\hline & ELEMENTOS & REFINO DO & Quimicos & FARMACÉUTICA & ARTIGOS \\
\hline & Quimicos & PETRÓLEO & DIVERSOS & E VETERINARIA & PLÁSTICOS \\
\hline Produção & 7288455,912 & 25269021,71 & 8408238,135 & 5466603,946 & 4038613,057 \\
\hline Consumo Intermediário & 4455988,593 & 13717267,81 & 5563396,943 & 3119204,335 & 2297770,641 \\
\hline Valor adic. ao preço básico & 2832467,319 & 11551753,9 & 2844841,192 & 2347399,611 & 1740842,416 \\
\hline
\end{tabular}

\begin{tabular}{|c|c|c|c|c|c|}
\hline \multirow[b]{2}{*}{$\begin{array}{l}\text { CODIGO } \\
\text { PRODUTO }\end{array}$} & \multicolumn{5}{|c|}{ Descriçāo do Produto Nivel 80} \\
\hline & $\begin{array}{c}22 \\
\text { INDÚSTRIA } \\
\text { TEXTRL }\end{array}$ & $\begin{array}{c}23 \\
\text { ARTIGOS DO } \\
\text { VESTUARIO }\end{array}$ & $\begin{array}{c}24 \\
\text { FABRICAÇÃO DE } \\
\text { CALCADOS }\end{array}$ & $\begin{array}{c}25 \\
\text { INDÚSTRIA DO } \\
\text { CAFE }\end{array}$ & $\begin{array}{c}26 \\
\text { BENEFICIAM. } \\
\text { PROD. VEGETAIS }\end{array}$ \\
\hline $5 \pi$ & 3,85 & 4590 & 359 & 3063879,83 & 106012 \\
\hline & & 94 & 25 & 22906 & 7485 \\
\hline alor adic. ao preço básico & 2983824,782 & 1460490,102 & 1634139,671 & 773239,6952 & 3116135,584 \\
\hline
\end{tabular}

\begin{tabular}{|c|c|c|c|c|c|}
\hline \multirow{4}{*}{$\begin{array}{l}\text { CÓDIGO } \\
\text { PRODUTO } \\
\text { NMEL } 80\end{array}$} & \multicolumn{5}{|c|}{ Descriçâo do Produto Nivel 80} \\
\hline & 27 & 28 & 29 & 30 & 31 \\
\hline & ABATE DE & INDÚSTRIA DE & FABRICAÇÃO DE & FABRICAÇẢO DE & OUT. PRODUTOS \\
\hline & ANIMAIS & LATICINIOS & AÇÚCAR & OLEOS VEGETAIS & ALMENTARES \\
\hline Valor da Produção & 10840566,15 & 4383260,536 & 3029145,77 & 5647644,576 & 12769495,62 \\
\hline Consumo Intermediáni & 8384777,106 & 3536029,204 & 2365687,852 & 5471282,161 & 9001343,851 \\
\hline Valor adic. ao preço básico & 2455789,04 & 847231,3326 & 663457,9185 & 176362,4142 & 3768151,771 \\
\hline
\end{tabular}


Apêndice 5.6. Continuação.

\begin{tabular}{|c|c|c|c|c|c|}
\hline \multirow[b]{2}{*}{ CÓDsGo } & \multicolumn{5}{|c|}{ Deceriçăo do Produto Nivel 80} \\
\hline & 32 & 33 & 34 & 35 & 38 \\
\hline PRODUTO & INDÜSTRIAS & & CONSTRUÇÄO & & \\
\hline NIVEL 80 & DIVERSAS & S.I.U.P. & CML & COMÉRCIO & TRANSPORTES \\
\hline Valor da Produção & 4119561,567 & 19816719,21 & 49851526,57 & 50014724,26 & 25473566,81 \\
\hline Consumo Intermediário & 2264416,67 & 10369491,43 & 22347166,04 & 20264641,15 & 12278639,65 \\
\hline Valor adic. ao preco básico & 1855144,896 & 9447227,784 & 27504360,53 & 29750083,12 & 13194927,16 \\
\hline
\end{tabular}

\begin{tabular}{|c|c|c|c|c|c|}
\hline \multirow[b]{2}{*}{ COODIGO } & \multicolumn{5}{|c|}{ Descriçåo do Produto Nivel 80} \\
\hline & 37 & 38 & 39 & 40 & 41 \\
\hline PRODUTO & & INSTITUIÇÕES & SERV. PREST. & SERV. PREST. & ALUGUEL DE \\
\hline NIVEL 80 & COMUNICAÇŌES & FINANCEIRAS & À FAMILLA & A EMPRESA & IMÓVEIS \\
\hline Valor da Produção & 7341540,71 & 114010921,7 & 41494564,19 & 19167076,89 & 23695047,31 \\
\hline Consumo Intermediário & 1748464,897 & 10198520,78 & 17043091,2 & 4585380,213 & 1952217,191 \\
\hline Valor adic. ao preço básico & 5593075,813 & 103812400,9 & 24451473 & 14581696,68 & 21742830,12 \\
\hline
\end{tabular}

\begin{tabular}{|c|c|c|c|c|c|}
\hline \multirow[b]{2}{*}{ cóolgo } & \multicolumn{5}{|c|}{ Descriçäo do Produto Nivel 80} \\
\hline & 42 & 43 & 46 & & \\
\hline $\begin{array}{l}\text { PRODUTO } \\
\text { NIVEL } 80\end{array}$ & $\begin{array}{c}\text { ADMINISTRAÇẢO } \\
\text { PÚBLICA }\end{array}$ & $\begin{array}{l}\text { SERV. PRIV. } \\
\text { N MERCANTIS }\end{array}$ & $\begin{array}{c}\text { DUMMY } \\
\text { FINANCEIRO }\end{array}$ & TOTAL & INDÚSTRIA \\
\hline Valor da Produçāo & 68891196,6 & 4497355,586 & 0 & 699328677 & 299705894,8 \\
\hline Consumo Intermediário & 22335137,96 & 371953,6201 & 98096313,56 & 391239615,6 & 184054652 \\
\hline Valor adic ao preco básico & 46556058,64 & 4125401,966 & $-98096313,56$ & 308089061,4 & 115651242,8 \\
\hline
\end{tabular}

\begin{tabular}{|c|c|c|c|c|}
\hline \multirow{2}{*}{$\begin{array}{l}\text { CÓDIGO } \\
\text { PRODUTO } \\
\text { NMEL } 80\end{array}$} & \multicolumn{4}{|c|}{ Descrlçảo do Produto Nivet 80} \\
\hline & Serviços & Jusante 1 & Jusante2 & Jusante 3 \\
\hline Valor da Produção & 354585994,05 & 44854240,51 & 64255892,12 & 74322765,96 \\
\hline Consumo Intermediário & 90778046,65 & 33989557,21 & 46922131,84 & 54005180,91 \\
\hline Valor adic. ao preco básico & 263807947,40 & 10864683,30 & 17333760,27 & 20317585.05 \\
\hline
\end{tabular}

Fonte: Dados básicos do IBGE.

Elaborados pela autora. 
Apêndice 5.7. Estimativas a preços constantes do valor adicionado das diferentes atividades produtivas brasileiras, deflacionadas por produto - 1994.

\begin{tabular}{|c|c|c|c|c|c|}
\hline \multirow[b]{2}{*}{ código } & \multicolumn{5}{|c|}{ Descriçăo do Produto Nivel 80} \\
\hline & 04 & 02 & 03 & 04 & 06 \\
\hline PRODUTO & & EXTRATIVA & PETRÓLEO & MINERAL & \\
\hline NIVEL 80 & AGROPECUARIA & MINERAL & E GAS & N METÁLICO & SIDERURGIA \\
\hline Valor da Produçăo & 50344517,08 & 3544305,323 & 2818364,309 & 9035088,623 & 14160340,55 \\
\hline Consumo Intermediário & 19890015 & 2019856 & 1766210 & 5052375 & 10854448,36 \\
\hline Valor adic. ao preço básico & 30454502,08 & 1524449,323 & 1052154,309 & 3982713,623 & 3305892,181 \\
\hline
\end{tabular}

\begin{tabular}{|c|c|c|c|c|c|}
\hline \multirow{4}{*}{$\begin{array}{l}\text { CODIGO } \\
\text { PRODUTO } \\
\text { NIVEL } 80\end{array}$} & \multicolumn{5}{|c|}{ Descriçåo do Produto Nivel 80} \\
\hline & 06 & 07 & 08 & 10 & 11 \\
\hline & METALÚRGIA & OUTROS & MÁQUINASE & MATERIAL. & EQUIPAMENTOS \\
\hline & N FERROSOS & METALÚRGICOS & TRATORES & ELÉTRICO & ELETRÓNICOS \\
\hline Valor da Produçáo & 5297062,827 & 11520823,09 & 14414539 & 6790745 & 7002093 \\
\hline Consumo Intermedis & 3736866 & 7092324 & 6151866 & 4601548 & 4091506 \\
\hline Valor adic. ao preço básico & 1560196,827 & 4428499,091 & 8262673 & 2189197 & 2910587 \\
\hline
\end{tabular}

\begin{tabular}{|c|c|c|c|c|c|}
\hline \multirow[b]{2}{*}{ CÓDIGO } & \multicolumn{5}{|c|}{ Descriçăo do Produto Nivel 80} \\
\hline & 12 & 13 & 14 & 16 & 16 \\
\hline PRODUTO & AUTOM.,ÓNIBUS & PEÇAS E OUTROS & MADEIRAE & CELUL., PAPEL & INDÚSTRIA \\
\hline NIVEL 80 & E CAMINHÓES & VEICULOS & MOBILIÁRIO & E GRAFICA & DA BORRACHA \\
\hline Valor da Produção & 8959781,909 & 10689515,09 & 6988581 & 10235940,27 & 3903514,639 \\
\hline Consumo Intermediário & 6384094,362 & 6894999 & 4065703 & 7443930 & 2651495 \\
\hline Valor adic. ao preço básico & 2575687,547 & 3794516,091 & 2922878 & 2792010,273 & 1252019,639 \\
\hline
\end{tabular}

\begin{tabular}{|c|c|c|c|c|c|}
\hline \multirow{4}{*}{$\begin{array}{l}\text { CÓDIGO } \\
\text { PRODUTO } \\
\text { NIVEL 80 }\end{array}$} & \multicolumn{5}{|c|}{ Descriçăo do Produto Nivel 80} \\
\hline & 17 & 18 & $\overline{19}$ & 20 & 21 \\
\hline & ELEMENTOS & REFINO DO & QUIMIcos & FARMACÊUTICA & ARTIGOS \\
\hline & Químicos & PETRÓLEO & DIVERSOS & E VETERINÁRIA & PLÁsticos \\
\hline Valor da Produçáa & 8042007,068 & 27387088.51 & 9315190,141 & 5771183,939 & 4299215,455 \\
\hline Consumo Intermediário & 4519630 & 15627589 & 6419775 & 3149314 & 2559417 \\
\hline \multirow[t]{2}{*}{ Valor adic. ao preço básico } & 3522377,068 & 11759499,51 & 2895415,141 & 2621869,939 & 1739798,455 \\
\hline & \multicolumn{5}{|c|}{ Descriçăo do Produto Nivel 80} \\
\hline CÓDIGO & 22 & 23 & 24 & 25 & 26 \\
\hline PRODUTO & INDÚSTRIA & ARTIGOS DO & FABRICACAO DE & INDÚSTRIA DO & BENEFICIAM. \\
\hline NIVEL 80 & TEXTIL & VESTUÁRIO & CALÇADOS & CAFE & PROD. VEGETAIS \\
\hline Valor da Produçáo & 10276352,56 & 5147676,567 & 3518950,368 & 3959181,074 & 10557933,25 \\
\hline Consumo Intermediário & 7397401,546 & 3147682 & 2282875 & 2990056,999 & 7727365,636 \\
\hline \multirow[t]{2}{*}{ Valor adic. ao preço básico } & 2878951,016 & 1999994,567 & 1236075,368 & 969124,075 & 2830567,616 \\
\hline & \multicolumn{5}{|c|}{ Descriçăo do Produto Nivel 80} \\
\hline CODIGO & 27 & 28 & 29 & 30 & 31 \\
\hline PRODUTO & ABATE DE & INDÚSTRIA DE & FABRICAÇĀO DE & FABRICAÇÃO DE & OUT. PRODUTOS \\
\hline NIVEL 80 & ANIMAIS & LATICINIOS & AÇÚCAR & ÓLEOS VEGETAIS & S ALIMENTARES \\
\hline Valor da Produçă & 9705980,974 & 3943750,914 & 3362792,182 & 6859430,823 & 13528652,97 \\
\hline Consumo Intermediá & 7829080 & 3239858,636 & 2591646 & 5679143 & 9652351,636 \\
\hline Valor adic. ao preco & 1876900,974 & 703892,278 & 771146,182 & 1180287,823 & 3876301,33 \\
\hline
\end{tabular}


Apêndice 5.7. Continuaçāo.

\begin{tabular}{|c|c|c|c|c|c|}
\hline \multirow[b]{2}{*}{ cobico } & \multicolumn{5}{|c|}{ Descriçáo do Produto Nivel 80} \\
\hline & 32 & 33 & 34 & 36 & 36 \\
\hline Proouto & MDUSTRIAS & & CONSTRUÇĀO & & \\
\hline NVEL 80 & DNERSAS & S.I.U.P. & CIVIL & COMÉRCIO & TRANSPORTES \\
\hline Valor da Produçáo & 4236729,545 & 18890645 & 51917740 & 47627317,85 & 23422677,09 \\
\hline Consumo Intermediário & 2277309 & 9521768 & 23425868,09 & 18382471,64 & 12622463,81 \\
\hline Valor adic. ao preço básico & 1959420,545 & 9368877 & 28491871,91 & 29244846,21 & 10800213,28 \\
\hline
\end{tabular}

\begin{tabular}{|c|c|c|c|c|c|}
\hline \multirow[b]{2}{*}{ cobico } & \multicolumn{5}{|c|}{ Descriçấo do Produto Nivel 80} \\
\hline & 37 & 38 & 39 & 40 & 41 \\
\hline PROOUTO & & INSTTUUICOEES & SERV. PREST. & SERV. PREST. & ALUGUEL DE \\
\hline Nevel 80 & COMUNICAÇÓES & FINANCEIRAS & A FAMILIA & A EMPRESA & IMÓVEIS \\
\hline Valor da Produça & 6048882 & 58873368 & 38345356,36 & 16539528 & 23422740,91 \\
\hline Consumo Intermediário & 1544084 & 9699286 & 17171183,09 & 4478073 & 2046141 \\
\hline Valor adic. ao preço básico & 4504798 & 49174082 & 21174173,27 & 12061455 & 21376599,91 \\
\hline
\end{tabular}

\begin{tabular}{|c|c|c|c|c|c|}
\hline \multirow[b]{2}{*}{ coblat } & \multicolumn{5}{|c|}{ Descriçăo do Produto Nivel 80} \\
\hline & 42 & 43 & 46 & & \\
\hline $\begin{array}{l}\text { PROOUTO } \\
\text { NIVI } 80\end{array}$ & $\begin{array}{c}\text { ADMINISTRAÇAOO } \\
\text { PÚBLICA }\end{array}$ & $\begin{array}{l}\text { SERV. PRIV. } \\
\text { N MERCANTIS }\end{array}$ & $\begin{array}{c}\text { DUMMY } \\
\text { FINANCEIRO }\end{array}$ & TOTAL & INDÚSTRIA \\
\hline Valor da Produçảo & 68963905 & 4150174 & 0 & 653819662,3 & 316081196 \\
\hline Consumo Intermediário & 21940163 & 373628 & 43620153 & 344613012,8 & 192845351,3 \\
\hline Valor adic. ao preço básico & 47023742 & 3776546 & -43620153 & 309206649,5 & 123235844,7 \\
\hline CoDiGo & \multicolumn{5}{|c|}{ Descriçáo do Produtio Nivel 80} \\
\hline PRODUTO & Serviços & Jusantel & Jusante2 & Jueante3 & \\
\hline \multicolumn{6}{|l|}{ NIVEL 80} \\
\hline Valor da Produçáo & 287393949,21 & 46431076,29 & 66948310,25 & 77224662,82 & \\
\hline Consumo Intermediário & 88257493,54 & 34576780,27 & 48294834,91 & 55692236,45 & \\
\hline Valor adic. ao preco básico & 199136455,67 & 11854296,02 & 18653475,35 & 21532426,36 & \\
\hline
\end{tabular}

Fonte: Dados básicos do IBGE.

Elaborados pela autora. 


\section{APÊNDICE 6}

A 6.1 Estimativas a preços constantes do valor adicionado das diferentes atividades produtivas brasileiras, deflacionadas por atividades -1980 ..

A 6.2 Estimativas a preços constantes do valor adicionado das diferentes atividades produtivas brasileiras, deflacionadas por atividades - 1985 ..

A 6.3 Estimativas a preços constantes do valor adicionado das diferentes atividades produtivas brasileiras, deflacionadas por atividades - 1990 ..

A 6.4 Estimativas a preços constantes do valor adicionado das diferentes atividades produtivas brasileiras, deflacionadas por atividades - 1991 ..

A 6.5 Estimativas a preços constantes do valor adicionado das diferentes atividades produtivas brasileiras, deflacionadas por atividades - 1992 ..

A 6.6 Estimativas a preços constantes do valor adicionado das diferentes atividades produtivas brasileiras, deflacionadas por atividades - 1993 .

A 6.7 Estimativas a preços constantes do valor adicionado das diferentes atividades produtivas brasileiras, deflacionadas por atividades - 1994 .. 
Apêndice 6.1. Estimativas a preços constantes do valor adicionado das diferentes atividades produtivas brasileiras, deflacionadas por atividades - 1980 .

\begin{tabular}{|c|c|c|c|c|c|}
\hline \multirow[b]{2}{*}{ CÓDIGO } & \multicolumn{5}{|c|}{ Descriçaso do Produto Nivel 80} \\
\hline & 01 & 02 & 03 & 04 & 0.5 \\
\hline PRODUTO & & EXTRATIVA & PETRÓLEO & MINERAL & \\
\hline NNEL 80 & AGROPECUÁRIA & MINERAL & E GAS & Ñ METÁLICO & SIDERURGIA \\
\hline Valor da Produção & 50144896,22 & 1664997,275 & 462555,0506 & 19492413,03 & 7814839,437 \\
\hline Consumo Intermediário & 19840298,24 & 652079,647 & 188050,2012 & 11104642,64 & 6614883,199 \\
\hline Valor adic. ao preco básico & 30304597,98 & 1012917,628 & 274504,8493 & 8387770,383 & 1199956,238 \\
\hline
\end{tabular}

\begin{tabular}{|c|c|c|c|c|c|}
\hline \multirow[b]{2}{*}{ CÓOIGO } & \multicolumn{5}{|c|}{ Descriçăo do Produto Nivel 80} \\
\hline & 06 & 07 & 08 & 10 & 11 \\
\hline PRODUTO & METALÚRGIA & OUTROS & MAQUINASE & MATERIAL & EQUIPAMENTOS \\
\hline NIVEL 80 & N̂FERROSOS & METALÚRGICOS & TRATORES & ELÉTRICO & ELETRÓNICOS \\
\hline Valor da Produção & 2616505,053 & 6322342,991 & 17508474,02 & 3801573,291 & 3082888,01 \\
\hline Consumo Intermediário & 2103766,879 & 4005344,659 & 10491607,78 & 2480406,667 & 1850068,727 \\
\hline Valor adic. ao preço básico & 512738,1737 & 2316998,332 & 7016866,248 & 1321166,624 & 1232819,282 \\
\hline
\end{tabular}

\begin{tabular}{|c|c|c|c|c|c|}
\hline \multirow[b]{2}{*}{ COODIGO } & \multicolumn{5}{|c|}{ Descriçåo do Produto Nivel 80} \\
\hline & 12 & 13 & 14 & 15 & 16 \\
\hline PRODUTO & AUTOM.,ÓNIBUS & 'EÇAS E OUTROS & MADEIRAE & CELUL., PAPEL & INDÚSTRIA \\
\hline NMEL 80 & E CAMINHÖES & VEICULOS & MOBILIARIO & E GRÁFICA & DA BORRACHA \\
\hline Valor da Produção & 7069401,149 & 20482153,15 & 15078708,35 & 9066609,031 & 3448004,012 \\
\hline Consumo Intermediári & 5708595,607 & 13752956,86 & 9297837,434 & 5678769,956 & 2666984,583 \\
\hline Valor adic. ao preco bá & 1360805,542 & 6729196,285 & 5780870,918 & 3387839,075 & 781019,4294 \\
\hline
\end{tabular}

\begin{tabular}{|c|c|c|c|c|c|}
\hline \multirow[b]{2}{*}{ COODIGO } & \multicolumn{5}{|c|}{ Descriçăo do Produto Nivel 80} \\
\hline & 17 & 18 & 19 & 20 & 21 \\
\hline $\begin{array}{l}\text { PRODUTO } \\
\text { NMEL BO }\end{array}$ & ELEMENTOS & REFINO DO & QUIMICOS & FARMACÊUTICA & ARTIGOS \\
\hline Valor da Produção & 3337674 & 19103732,74 & 8885480,214 & 4123244,608 & 4012416,623 \\
\hline Consumo Intermediário & 2200439,643 & 15668474,55 & 6168520,965 & 2594508,392 & 2564301,246 \\
\hline Valor adic. ao preço básico & 1137234,356 & 3435258,189 & 2716959,249 & 1528736,216 & 1448115,377 \\
\hline
\end{tabular}

\begin{tabular}{|c|c|c|c|c|c|}
\hline \multirow{4}{*}{$\begin{array}{l}\text { CÓDIGO } \\
\text { PRODUTO } \\
\text { NIVEL } 80\end{array}$} & \multicolumn{5}{|c|}{ Descriçăo do Produto Nivel 80} \\
\hline & 22 & 23 & 24 & 25 & 28 \\
\hline & INDÚSTRIA & ARTIGOS DO & FABRICAÇẢO DE & INDÚSTRIA DO & BENEFICIAM. \\
\hline & TEXTIL & VESTUÁRIO & CALCCADOS & CAFE & PROD. VEGETAIS \\
\hline Valor da Produção & 8075659,867 & 4243945,29 & 1161158,664 & 6117603,514 & 12234685,03 \\
\hline Consumo Intermediánio & 5633555,845 & 2710524,042 & 695677,4169 & 5305639,158 & 9039847,46 \\
\hline Valor adic. ao preço básico & 2442104,022 & 1533421,248 & 465481,2468 & 811964,3561 & 3194837,572 \\
\hline
\end{tabular}

\begin{tabular}{|c|c|c|c|c|c|}
\hline \multirow{3}{*}{$\begin{array}{l}\text { CÓDIGO } \\
\text { PRODUTO } \\
\text { NMEL } 80\end{array}$} & \multicolumn{5}{|c|}{ Descriçáo do Produto Nivel 80} \\
\hline & 27 & 28 & 29 & 30 & 31 \\
\hline & $\begin{array}{l}\text { ABATE DE } \\
\text { ANIMAIS }\end{array}$ & $\begin{array}{l}\text { INDÚSTRIA DE } \\
\text { LATICINIOS }\end{array}$ & $\begin{array}{l}\text { FABRICAÇĀO DE } \\
\text { ACÚCAR }\end{array}$ & FABRICAÇĀO DE & OUT. PRODUTOS \\
\hline Valor da Produ & 8750183,001 & 6751670,664 & 2635991,467 & 3834224,879 & 12121798,62 \\
\hline Consumo Intermediári & 7520905,558 & 6024374,256 & 1991023,109 & 3292685,871 & 8667302,283 \\
\hline Valor adic. ao preço básico & 1229277,443 & 727296,4081 & 644968,3583 & 541539,0081 & 3454496,337 \\
\hline
\end{tabular}


Apêndice 6.1. Continuação

\begin{tabular}{|c|c|c|c|c|c|}
\hline \multirow[b]{2}{*}{ cópico } & \multicolumn{5}{|c|}{ Descriçảo do Produto Nivel 80} \\
\hline & 32 & 33 & 34 & 35 & 36 \\
\hline PRODUTO & INDÚSTRIAS & & CONSTRUÇÃO & & \\
\hline NNEL 80 & DNERSAS & S.I.U.P. & CML & COMÉRCIO & TRANSPORTES \\
\hline a Produção & 6127921,204 & 10482744,76 & 61498908,89 & 63578827,37 & 29068087,47 \\
\hline Consumo Intermediário & 4374547,536 & 5035579,459 & 37485012,02 & 25681000,28 & 15149853,39 \\
\hline Valor adic. ao preço básico & 1753373,668 & 5447165,301 & 24013896,88 & 37897827,08 & 13918234,08 \\
\hline
\end{tabular}

\begin{tabular}{|c|c|c|c|c|c|}
\hline \multirow[b]{2}{*}{ CóDIGO } & \multicolumn{5}{|c|}{ Descricão do Produto Nivel 80} \\
\hline & 37 & 38 & 39 & 40 & 41 \\
\hline PRODUTO & & INSTITUIÇŌES & SERV. PREST. & SERV. PREST. & ALUGUel DE \\
\hline NNELL 80 & COMUNICAÇÕES & FINANCEIRAS & A FAMILIA & A EMPRESA & IMÓVEIS \\
\hline Valor da Produçäo & 4334590,208 & 37629888,97 & 42765874,7 & 43111705 & 31043099,94 \\
\hline Consumo Intermediário & 1319176,514 & 7806059,007 & 21350972,16 & 30110169,49 & 4500937,8 \\
\hline Valor adic. ao preco básico & 3015413,694 & 29823829,96 & 21414902,54 & 13001535,51 & 26542162,14 \\
\hline
\end{tabular}

\begin{tabular}{|c|c|c|c|c|c|}
\hline \multirow{3}{*}{$\begin{array}{l}\text { CÓDIGO } \\
\text { PRODUTO } \\
\text { NMEL } 80\end{array}$} & \multicolumn{5}{|c|}{ Descriç3̄o do Produto Nivel 80} \\
\hline & 42 & 43 & 46 & & \\
\hline & $\begin{array}{c}\text { ADMINISTRAÇÃO } \\
\text { PÚBLICA }\end{array}$ & $\begin{array}{l}\text { SERV. PRIV. } \\
\text { N MERCANTIS }\end{array}$ & $\begin{array}{c}\text { DUMMY } \\
\text { FINANCEIRO }\end{array}$ & TOTAL & INDÚSTRIA \\
\hline Valor da Produção & 42527666,66 & 5706368,446 & 0 & 651321512,9 & 301410507,9 \\
\hline Consumo Intermediário & 12240004,62 & 422895,811 & 28259311,42 & 370249592,4 & 203568913,6 \\
\hline Valor adic. ao preco básico & 30287662,04 & 5283472,635 & $-28259311,42$ & 281071920,5 & 97841594,24 \\
\hline
\end{tabular}

\begin{tabular}{ccccc}
\hline Código & \multicolumn{4}{c}{ Descrição do Produto Nivel 80 } \\
\cline { 2 - 5 } PRODUTO & Serviços & Jusante1 & Jusante2 & Jusante3 \\
NNEL 80 & & & & \\
\hline Valor da Produção & 299766108,77 & 43662032,56 & 70862539,53 & 78938199,40 \\
Consumo Intermediário & 118581069,09 & 35374915,05 & 53340054,77 & 58973610,62 \\
Valor adic. ao preco básico & 181185039,68 & 8287117,50 & 17522484,76 & 19964588,78 \\
\hline
\end{tabular}

Fonte: Dados básicos do IBGE. Elaborados pela autora.

Elaborados pela autora. 
Apêndice 6.2. Estimativas a preços constantes do valor adicionado das diferentes atividades produtivas brasileiras, deflacionadas por atividades - 1985.

\begin{tabular}{|c|c|c|c|c|c|}
\hline \multirow[b]{2}{*}{ cobtco } & \multicolumn{5}{|c|}{ Descriçálo do Produto Nivel 80} \\
\hline & 01 & 02 & 03 & 24 & 05 \\
\hline PRODUTO & & EXTRATIVA & PETRÓLEO & MINERAL & \\
\hline NIVEL 80 & AGROPECUÁRIA & MINERAL & E GÁS & N METÁLICO & SIDERURGIA \\
\hline Valor da Produçáo & 55399682,22 & 2145000,201 & 2708100,175 & 12609774,08 & 14718917,8 \\
\hline Consumo Intermediário & 21259679,43 & 922814,1128 & 769760,1906 & 7851806,682 & 11812096,81 \\
\hline Valor adic. ao preço básico & 34140002,8 & 1222186,088 & 1938339,984 & 4757967,395 & 2906820,989 \\
\hline
\end{tabular}

\begin{tabular}{|c|c|c|c|c|c|}
\hline \multirow{3}{*}{$\begin{array}{l}\text { CODDIGO } \\
\text { PRODUTOO }\end{array}$} & \multicolumn{5}{|c|}{ Descriçăo do Produto Nivel 80} \\
\hline & 06 & 07 & 08 & 10 & 11 \\
\hline & METALÚRGIA & OUTROS & MÁQUINAS E & MATERIAL & EQUIPAMENTOS \\
\hline NIVEL 80 & NFERROSOS & METALÚRGICOS & TRATORES & ELÉTRICO & ELETRONICOS \\
\hline Valor da Produçáo & 3792679,612 & 9073791,292 & 14976155,91 & 3794068,055 & 4084396,956 \\
\hline Consumo Intermediário & 2646922,797 & 5632227,706 & 7967079,767 & 2493958,66 & 2185940,354 \\
\hline Valor adic. ao preço básico & 1145756,815 & 3441563,586 & 7009076,144 & 1300109,395 & 1898456,602 \\
\hline
\end{tabular}

\begin{tabular}{|c|c|c|c|c|c|}
\hline \multirow[b]{2}{*}{ COODFO } & \multicolumn{5}{|c|}{ Descriçăo do Produto Nivel 80} \\
\hline & 12 & 13 & 14 & 16 & 16 \\
\hline PROOUTO & AUTOM.,ONIBUS & PEÇAS E OUTROS & MADEIRAE & CELUL., PAPEL & INDÚSTRIA \\
\hline NNEL 80 & E CAMINHÓES & VEÍCULOS & MOBILIÁRIO & E GRÁFICA & DA BORRACHA \\
\hline Valor da Produçảo & 7925185,583 & 14550869,18 & 10342838,62 & 9550151,833 & 3431701,768 \\
\hline Consumo Intermediário & 6360901,351 & 9039193,322 & 6003525,894 & 5681468,718 & 2294165,984 \\
\hline Valor adic. ao preço básico & 1564284,232 & 5511675,853 & 4339312,728 & 3868683,114 & 1137535,783 \\
\hline
\end{tabular}

\begin{tabular}{|c|c|c|c|c|c|}
\hline \multirow{3}{*}{$\begin{array}{l}\text { CÓDIGO } \\
\text { PROOUTO } \\
\text { NIVEL } 80\end{array}$} & \multicolumn{5}{|c|}{ Descriçăo do Produto Nivel 80} \\
\hline & 17 & 18 & 19 & 20 & 21 \\
\hline & ELEMENTOS & REFINO DO & $\begin{array}{l}\text { Quimicos } \\
\text { DIVERSOS }\end{array}$ & $\begin{array}{l}\text { FARMACEUTICA } \\
\text { E VETERINÁRIA }\end{array}$ & $\begin{array}{l}\text { ARTIGOS } \\
\text { PLÁSTICOS }\end{array}$ \\
\hline Valor da Produçáo & 5675314,954 & 23292461,64 & 7752641,499 & EVETERINARIA & 3633115,214 \\
\hline Consumo Intermediário & 3708559,976 & 19013580,73 & 5038879,549 & 2449013,127 & 2204682,841 \\
\hline Valor adic. ao preço básico & 1966754,978 & 4278880,906 & 2713761,95 & 1684010,157 & 1428432,372 \\
\hline & \multicolumn{5}{|c|}{ Descriçác do Produto Nivel 80} \\
\hline CODDIGO & 22 & 23 & 24 & 25 & 26 \\
\hline PRODUTO & INDÚSTRIA & ARTIGOS DO & FABRICAÇĀO DE & INDÚSTRIADO & BENEFICIAM. \\
\hline NIVEL 80 & TEXTL & VESTUÁRIO & CALCAADOS & CAFÉ & PROD. VEGETAIS \\
\hline Valor da Produçáo & 8957984,896 & 5737264,134 & 2437126,181 & 6542240,576 & 11199034,8 \\
\hline Consumo Intermediário & 5912801,519 & 3194539,647 & 1536824,391 & 5445324,045 & 7855596,018 \\
\hline Valor adic. ao preço básico & 3045183,377 & 2542724,487 & 900301,7897 & 1096916,531 & 3343438,779 \\
\hline
\end{tabular}

\begin{tabular}{|c|c|c|c|c|c|}
\hline \multirow[b]{2}{*}{ cóDiGo } & \multicolumn{5}{|c|}{ Descriçăo do Produto Nivel 80} \\
\hline & 27 & 28 & 29 & 30 & 31 \\
\hline PRODUTO & ABATE DE & INDÚSTRIA DE & FABRICACAODE & FABRICAÇAO DE & OUT. PRODUTOS \\
\hline NIVEL 80 & ANIMAIS & LATICINIOS & AÇÚCAR & ÓLEOS VEGETAIS & ALIMENTARES \\
\hline Valor da Produça & 8480569,825 & 5599184,943 & 2262735,129 & 4200175,65 & 9891255,454 \\
\hline Consumo Intermediário & 7200533,667 & 4584270,218 & 1782109,128 & 3494916,003 & 7405349,296 \\
\hline Valor adic. ao preço básico & 1280036,158 & 1014914,725 & 480626,0006 & 705259,6471 & 2485906,158 \\
\hline
\end{tabular}


Apêndice 6.2. Continuação.

\begin{tabular}{|c|c|c|c|c|c|}
\hline \multirow[b]{2}{*}{ cobloo } & \multicolumn{5}{|c|}{ Descriçāo do Produto Nivel 80} \\
\hline & 32 & 33 & 34 & 35 & 36 \\
\hline PRODUTO & IMDUSTRIAS & & CONSTRUÇAO & & \\
\hline NVEL 80 & ONERSAS & S.I.U.P. & CIVIL & COMERCIO & TRANSPORTES \\
\hline Valor da Produçáo & 4024301,941 & 12304523,86 & 54652739,14 & 59424502,76 & 25880713,5 \\
\hline Consumo Intermediário & 2112939,478 & 6409665,701 & 32562403,02 & 20112977,8 & 14242848,61 \\
\hline \multirow[t]{2}{*}{ Valor adic. ao preço básico } & 1911362.463 & 5894858,163 & 22090336.13 & 39311524,96 & 11637864,89 \\
\hline & \multicolumn{5}{|c|}{ Descriçáo do Produto Nivel 80} \\
\hline COOAGO & 37 & 38 & 39 & 40 & 41 \\
\hline PROOUTO & & INSTITUIÇOEES & SERV. PREST. & SERV. PREST. & ALUGUEL DE \\
\hline NNEL 80 & COMUNICAÇÓES & FINANCEIRAS & A FAMILIA & A EMPRESA & IMÓVEIS \\
\hline Vator da Produçăo & 4702264,258 & 6 & 34542659,57 & 17801328,62 & 14920619,18 \\
\hline Consumo Intermediário & 1116201,138 & 9044826,237 & 18810462,12 & 3994943,447 & 2327948,193 \\
\hline Valor adic. ao preço básico & 3586063,121 & 47807805,22 & 15732197,45 & 13806385,17 & 12592670.99 \\
\hline
\end{tabular}

\begin{tabular}{|c|c|c|c|c|c|}
\hline \multirow[b]{2}{*}{ COOOIGO } & \multicolumn{5}{|c|}{ Descriçăo do Produto Nivel 80} \\
\hline & 42 & 43 & 46 & & \\
\hline $\begin{array}{l}\text { PRODUTO } \\
\text { AIVEL } 80\end{array}$ & $\begin{array}{l}\text { ADMINISTRAÇĀO } \\
\text { PÚBLCACA }\end{array}$ & $\begin{array}{l}\text { SERV. PRIV. } \\
\text { N MERCANTIS }\end{array}$ & $\begin{array}{c}\text { DUMMY } \\
\text { FINANCEIRO }\end{array}$ & TOTAL & INDÚSTRIA \\
\hline Valor da Produçso & 52319539,67 & 3407617,068 & 0 & 619730882,5 & 294479324,2 \\
\hline Consumo Intermediário & 17335682,77 & 399325,7343 & 46019410,44 & 348238156,6 & 193573850,7 \\
\hline Valor adic ao preco básico & 34983856.9 & 3008291,334 & $-46019410,44$ & 271492725,9 & 100905473,5 \\
\hline
\end{tabular}

\begin{tabular}{|c|c|c|c|c|}
\hline \multirow{2}{*}{$\begin{array}{l}\text { COOIGO } \\
\text { PROOUTO } \\
\text { NIVEL } 80\end{array}$} & \multicolumn{4}{|c|}{ Descriçăo do Produto Nivel 80} \\
\hline & Sonvicos & Jussnte1 & Jusante2 & Jusante 3 \\
\hline Valor da Produçảo & 269851876,1 & 43959255,87 & 64193349,95 & 73151334,85 \\
\hline Consumo Intermediário & 87385216,05 & 34071309,06 & 47480184,25 & 53392985,77 \\
\hline Valor adic. ao preço básico & 182466660 & 9887946,818 & 16713165,7 & 19758349,08 \\
\hline
\end{tabular}

Fonte: Dados básicos do IBGE.

Elaborados pela autora. 
Apêndice 6.3. Estimativas a preços constantes do valor adicionado das diferentes atividades produtivas brasileiras, deflacionadas por atividades - 1990

\begin{tabular}{|c|c|c|c|c|c|}
\hline \multirow[b]{2}{*}{ COD:Go } & \multicolumn{5}{|c|}{ Descriça do Produto Nivel 80} \\
\hline & 04 & 02 & 03 & 04 & 85 \\
\hline PRODUTO & & EXTRATIVA & PETRÓLEO & MINERAL & \\
\hline NIVEL 80 & AGROPECUÁRIA & MINERAL & E GÁS & Ñ METÁLICO & SIDERURGLA \\
\hline Valor da Produção & 50455411,46 & 3850211,022 & 4699864,994 & 9874451,499 & 14629192,4 \\
\hline Consumo Intermediário & 21961598,6 & 2194782,934 & 2114647,81 & 6013830,318 & 11634955,59 \\
\hline Valor adic. ao preço básico & 28493812.87 & 1655428,089 & 2585217,185 & 3860621,181 & 2994236,812 \\
\hline
\end{tabular}

\begin{tabular}{|c|c|c|c|c|c|}
\hline \multirow[b]{2}{*}{ CODSGO } & \multicolumn{5}{|c|}{ Descriçäo do Produto Nivel 80} \\
\hline & 06 & 07 & 08 & 10 & 11 \\
\hline PRODUTO & METALÚRGLA & OUTROS & MÁQUINAS E & MATERLAL & EQUIPAMENTOS \\
\hline NINEL 80 & Ñ FERROSOS & METALURGICOS & TRATORES & ELÉTRICO & ELETRÓNICOS \\
\hline Valor da Produçăo & 4554836,73 & 11446479,76 & 12229718,22 & 4027444,352 & 4412119,877 \\
\hline Consumo Intermediario & 3388325,621 & 7379769,47 & 6697711,384 & 2650177,073 & 2688620,874 \\
\hline Valor adic. ao preço básico & 1166511,108 & 4066710,286 & 5532006,839 & 1377267,279 & 1723499,002 \\
\hline
\end{tabular}

\begin{tabular}{|c|c|c|c|c|c|}
\hline \multirow[b]{2}{*}{ COOHGO } & \multicolumn{5}{|c|}{ Descriçåo do Produto Nivel 80} \\
\hline & 12 & 13 & 14 & 15 & 16 \\
\hline PRODUTO & AUTOM.,ONIBUS & EÇAS E OUTROS & MADEIRAE & CELUL., PAPEL & INDÚSTRLA \\
\hline NNEL 80 & E CAMINHÓES & VEICULOS & MOBILIARIO & E GRAFICA & DA BORRACHA \\
\hline Valor da Produçāo & 6434280,316 & 8538161,406 & 6137734,429 & 9622496,222 & 5295520,013 \\
\hline Consumo Intermediário & 4973498,034 & 5799519,365 & 3831891,727 & 6765793,988 & 3662033,839 \\
\hline Valor adic. ao preco básico & 1460782,283 & 2738642,041 & 2305842,702 & 2856702,234 & 1633486,174 \\
\hline
\end{tabular}

\begin{tabular}{ccccccc}
\hline & \multicolumn{5}{c}{ Descriçảo do Produto Nivel 80 } \\
\cline { 2 - 6 } CÓDIGo & $\mathbf{1 7}$ & $\mathbf{1 8}$ & $\mathbf{1 9}$ & $\mathbf{2 0}$ & $\mathbf{2 1}$ \\
PRODUTO & ELEMENTOS & REFINO DO & QUIMICOS & FARMACEUTICA & ARTIGOS \\
NNEL 80 & QUIMICOS & PETROLEO & ONVERSOS & E VETERINARIA & PLASTICOS \\
\hline Valor da Produção & 6485480,924 & 27374257,03 & 9432047,051 & 5170947,343 & 4980929,022 \\
Consumo Intermediário & 4307525,882 & 19282064,95 & 6052796,148 & 3181002,895 & 2801761,393 \\
Valor adic. ao preço básico & 2177955,042 & 8092192,076 & 3379250,903 & 1989944,447 & 2179167,629 \\
\hline
\end{tabular}

\begin{tabular}{|c|c|c|c|c|c|}
\hline \multirow[b]{2}{*}{ CÓDtGo } & \multicolumn{5}{|c|}{ Descrięāo do Produto Nivel 80} \\
\hline & 22 & 23 & 24 & 25 & 26 \\
\hline PRODUTO & INDÚSTRIA & ARTIGOS DO & FABRICAÇÃO DE & INDÚSTRIA DO & BENEFICIAM. \\
\hline NNEL 80 & TEXTIL & VESTUARIO & CALÇADOS & CAFÉ & PROD. VEGETAIS \\
\hline Valor da Produção & 9174679,676 & 3432125,862 & 3547192,979 & 2595398,987 & 9919213,553 \\
\hline Consumo Interm & 6217742,807 & 2062643,109 & 2532304,33 & 2066424,156 & 7472740,504 \\
\hline Valor adic. ao preço básico & 2956936,869 & 1369482,753 & 1014888,648 & 528974,8306 & 2446473,049 \\
\hline
\end{tabular}

\begin{tabular}{|c|c|c|c|c|c|}
\hline \multirow{4}{*}{$\begin{array}{l}\text { CÓDIGO } \\
\text { PRODUTO } \\
\text { NIVEL } 80\end{array}$} & \multicolumn{5}{|c|}{ Descriçăo do Produto Nivel 80} \\
\hline & 27 & 28 & 29 & 30 & 31 \\
\hline & ABATE DE & INDÚSTRLA DE & FABRICAÇÃO DE & FABRICAÇÃO DE & OUT. PRODUTOS \\
\hline & ANIMAIS & LATICINIOS & AÇÚCAR & OLEOS VEGETAIS & ALIMENTARES \\
\hline Valor da Produção & 9413278,193 & 5391593,864 & $2677335, \overline{596}$ & 5602676,036 & 12908953,69 \\
\hline Consumo Intermediáric & 914004,104 & 4445204,815 & 2033167,894 & 4726764,175 & 9575660,052 \\
\hline Valor adic. ao preço básico & 1499274,089 & 946389,0496 & 644167,7025 & 875911,8613 & 3333293,63 \\
\hline
\end{tabular}


Apêndice 6.3. Continuação.

\begin{tabular}{|c|c|c|c|c|c|}
\hline \multirow[b]{2}{*}{ CÓDIGO } & \multicolumn{5}{|c|}{ Descriçăo do Produto Nivel 80} \\
\hline & 32 & 33 & 34 & 35 & 36 \\
\hline PRODUTO & INDÚSTRLAS & & CONSTRUÇÃO & & \\
\hline NIVEL 80 & DIVERSAS & S.I.U.P. & $\mathrm{CML}$ & COMÉRCIO & TRANSPORTES \\
\hline Valor da Produção & 3818683,745 & 15606841,25 & 52873124,27 & 53736603,68 & 23520096,94 \\
\hline Consumo Intermediário & 2006715,965 & 8178739,21 & 28930191,93 & 20009945,3 & 12466933,85 \\
\hline \multirow[t]{2}{*}{ Valor adic. ao preco básico } & 1811967,78 & 7428102,042 & 23942932,34 & 33726658,38 & 11053163,09 \\
\hline & \multicolumn{5}{|c|}{ Descriçăo do Produto Nivel 80} \\
\hline CÓDIGO & 37 & 38 & 39 & 40 & 41 \\
\hline PRODUTO & & INSTITUIÇŐES & SERV. PREST. & SERV. PREST, & ALUGUEL DE \\
\hline NNEL 80 & COMUNICAÇŌES & FINANCEIRAS & A FAMILIA & A EMPRESA & IMÓVEIS \\
\hline Valor da Produção & 5478296,302 & 63263286,57 & 39331646,26 & 14729263,93 & 21932199,66 \\
\hline Consumo Intermediário & 1211102,403 & 8769557,696 & 18502950,87 & 4249770,563 & 2181189,514 \\
\hline \multirow[t]{2}{*}{ Valor adic. ao preço básico } & 4267193,899 & 54493728,87 & 20828695,39 & 10479493,37 & 19751010,15 \\
\hline & \multicolumn{5}{|c|}{ Descriçăo do Produto Nivel 80} \\
\hline CÓDIGO & 42 & 43 & 46 & & \\
\hline PRODUTO & ADMINISTRAÇÃO & SERV. PRIV. & DUMMY & TOTAL & INDÚSTRIA \\
\hline NNEL 80 & PÚBLICA & N MERCANTIS & FINANCEIRO & & \\
\hline Valor da Produçảo & 78152159,09 & 4013302,943 & 0 & 650769537,1 & 296157270,3 \\
\hline Consumo Intermediário & 20659280,53 & 351129,8718 & 52790405,94 & 356736877,5 & 193583012,3 \\
\hline Valor adic. ao preço básico & 57492878,56 & 3662173,072 & $-52790405,94$ & 294032659,7 & 102574258 \\
\hline CÓDIGO & \multicolumn{5}{|c|}{ Descrição do Produto Nivel 80} \\
\hline PRODUTO & Serviços & Jusante1 & Jusante2 & Jusante3 & \\
\hline \multicolumn{6}{|l|}{ NNEL 80} \\
\hline Valor da Produçảo & 304156855,37 & 42084977,15 & 61131665,27 & 70306344,94 & \\
\hline Consumo Intermediário & 88401860,59 & 32965831,53 & 46373383,31 & 52591126,11 & \\
\hline Valor adic. ao preço básico & 215754994,78 & 9119145,62 & 14758281,96 & 17715218,83 & \\
\hline
\end{tabular}

Fonte: Dados básicos do IBGE

Elaborados pela autora. 
Apêndice 6.4. Estimativas a preços constantes do valor adicionado das diferentes atividades produtivas brasileiras, deflacionadas por atividades - 1991.

\begin{tabular}{|c|c|c|c|c|c|}
\hline \multirow[b]{2}{*}{ cóoliso } & \multicolumn{5}{|c|}{ Descriçåo do Produto Nivel 80} \\
\hline & of & 02 & 03 & 04 & 05 \\
\hline PRODUTO & & EXTRATIVA & PETRÓLEO & MINERAL & \\
\hline NIVEL 80 & AGROPECUÁRIA & MINERAL & E GAS & N METÁLICO & SIDERURGIA \\
\hline Valor da Produção & 48766234,31 & 4248614,531 & 4100077,55 & 10263441,75 & 15213725,14 \\
\hline Consumo Intermediário & 20982915,47 & 2085402,618 & 1876540,352 & 5869778,18 & 11658571,01 \\
\hline Valor adic. ao preco básico & 27783318,84 & 2163211,913 & 2223537,198 & 4393663,57 & 3555154,126 \\
\hline
\end{tabular}

\begin{tabular}{|c|c|c|c|c|c|}
\hline \multirow[b]{2}{*}{ CÓDIGO } & \multicolumn{5}{|c|}{ Descriçåo do Produto Nivel 80} \\
\hline & 06 & 07 & 08 & 10 & 11 \\
\hline PRODUTO & METALÚRGIA & OUTROS & MÁQUINAS E & MATERIAL & EQUIPAMENTOS \\
\hline NMEL 80 & NF FERROSOS & METALÚRGICOS & TRATORES & ELÉTRICO & ELETRÓNICOS \\
\hline Valor da Produção & 4514975,759 & 11545485,68 & 12309594,11 & 4699124,131 & 5017452,07 \\
\hline Consumo Intermediário & 3256135,186 & 7116726,589 & 6373312,451 & 3046113,359 & 3013357,74 \\
\hline Valor adic. ao preco básico & $\{258840,573$ & 4428759,095 & 5936281,656 & 1653010,771 & 2004094,33 \\
\hline
\end{tabular}

\begin{tabular}{|c|c|c|c|c|c|}
\hline \multirow[b]{2}{*}{ CÓDigo } & \multicolumn{5}{|c|}{ Descriç̧̄o do Produto Nivel 80} \\
\hline & 12 & 13 & 14 & 15 & 16 \\
\hline PRODUTO & AUTOM.,ÓNIBUS & EÇAS E OUTROS & MADEIRAE & CELUL., PAPEL & INDÚSTRIA \\
\hline NMEL 80 & E CAMINHÕES & VEÍCULOS & MOBILLÁRIO & E GRÁFICA & DABORRACHA \\
\hline rodução & 6756062,226 & 842106 & 641499 & $\overline{1087}$ & 52736 \\
\hline Cons & 49 & 561188 & 3729 & 7046 & 359 \\
\hline Valor adic. ao preço básico & 1834195,004 & 2809177,408 & 2685223,213 & 3826883,374 & 1674546,266 \\
\hline
\end{tabular}

\begin{tabular}{|c|c|c|c|c|c|}
\hline \multirow[b]{2}{*}{$\begin{array}{l}\text { CODIGO } \\
\text { PRODUTO } \\
\text { NMEL } 80\end{array}$} & \multicolumn{5}{|c|}{ Descriçáco do Produto Nivel 80} \\
\hline & $\begin{array}{c}17 \\
\text { ELEMENTOS } \\
\text { QUIMICOS } \\
\end{array}$ & $\begin{array}{c}18 \\
\text { REFINO DO } \\
\text { PETRÓLEO }\end{array}$ & $\begin{array}{c}19 \\
\text { QUIMICOS } \\
\text { DINERSOS } \\
\end{array}$ & $\begin{array}{c}20 \\
\text { FARMACEUTICA } \\
\text { E VETERINARIA }\end{array}$ & $\begin{array}{c}21 \\
\text { ARTIGOS } \\
\text { PLASTICOS } \\
\end{array}$ \\
\hline 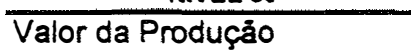 & 7521457,509 & 5678578,95 & 9969714,19 & 4788023,863 & 4682842,519 \\
\hline & 2 & 187 & 62 & 49 & 7,03 \\
\hline Valor adic. ao & 2733719,487 & 6948287,108 & 3740925,798 & 1602430,373 & 1937545,489 \\
\hline
\end{tabular}

\begin{tabular}{|c|c|c|c|c|c|}
\hline \multirow{3}{*}{$\begin{array}{l}\text { CÓDIGO } \\
\text { PRODUTO } \\
\text { NNEL } 80\end{array}$} & \multicolumn{5}{|c|}{ Descriçăa do Produto Nivel 80} \\
\hline & 22 & 23 & 24 & 25 & 26 \\
\hline & $\begin{array}{l}\text { INDÚSTRIA } \\
\text { TEXTL }\end{array}$ & $\begin{array}{l}\text { ARTIGOS DO } \\
\text { VESTUARIO }\end{array}$ & $\begin{array}{l}\text { FABRICAÇĀO DE } \\
\text { CALCADOS }\end{array}$ & INDÚSTRIA DO & $\begin{array}{l}\text { BENEFICIAM. } \\
\text { PROD. VEGETAIS }\end{array}$ \\
\hline Valor da Produçảo & 10017434,67 & 3526724,318 & 3903139,973 & 2476908,246 & 9258803,322 \\
\hline Consumo Intermediário & 7069383,318 & 2176511,399 & 2674444,752 & 1925613,739 & 6552936,829 \\
\hline \multirow[t]{2}{*}{ Valor adic. ao preco básico } & 2948051,349 & 1350212,919 & 1228695,221 & 551294,5065 & 2705866,493 \\
\hline & \multicolumn{5}{|c|}{ Descrlçåo do Produto Nivel 80} \\
\hline CÓDIGO & 27 & 28 & 29 & 30 & 31 \\
\hline PRODUTO & ABATE DE & INDÚSTRIA DE & FABRICAÇÃO DE & FABRICAÇÃO DE & OUT.PRODUTOS \\
\hline NMEL 80 & ANIMAIS & LATICINIOS & AÇÚCAR & ÓLEOS VEGETAIS & $S$ ALIMENTARES \\
\hline Valor da Produção & 9708659,906 & 4987266,395 & 3115310,453 & 5287785,44 & 12003178,36 \\
\hline Consumo Intermediário & 8076607,231 & 4135350,515 & 2395478,669 & 4292920,201 & 8679258,981 \\
\hline Valor adic. ao preço básico & 1632052,676 & 851915,8799 & 719831,7847 & 994865,2393 & $3 \quad 3323919,383$ \\
\hline
\end{tabular}


Apêndice 6.4. Continuacão.

\begin{tabular}{|c|c|c|c|c|c|}
\hline \multirow[b]{2}{*}{ cósGo } & \multicolumn{5}{|c|}{ Descriçáo do Produto Nivel 80} \\
\hline & 32 & 33 & 34 & 35 & 36 \\
\hline PRODUTO & INDÚSTRIAS & & CONSTRUÇÃO & & \\
\hline NIVEL 80 & DNERSAS & S.LU.P. & CIML & COMÉRCIO & TRANSPORTES \\
\hline Valor da Produção & 4057752,7 & 17746906,28 & 51253719 & 49383257,21 & 22047387,56 \\
\hline Consumo Intermediário & 2049311,592 & 10224796,6 & 27121707,75 & 18091682,76 & 10919689,43 \\
\hline \multirow[t]{2}{*}{ Valor adic. ao preco básico } & 2008441,108 & 7522109,683 & 24132011,25 & 31291574,45 & 11127698,14 \\
\hline & \multicolumn{5}{|c|}{ Descriçăo do Produto Nivel 80} \\
\hline COODGO & 37 & 38 & 38 & 40 & 41 \\
\hline PRODUTO & & INSTTUUIÇŐES & SERV. PREST. & SERV. PREST. & ALUGUEL DE \\
\hline NNEL 80 & COMUNICAÇŌES & FINANCEIRAS & A FAMILIA & À EMPRESA & IMÓVEIS \\
\hline Valor da Produçāo & 5480703,737 & 53084914,77 & 39553520,59 & 17267104,17 & 42748447,75 \\
\hline Consumo Intemediáno & 1775365,129 & 8561763,998 & 17676404,12 & 4245386,974 & 1962798,155 \\
\hline \multirow[t]{2}{*}{ Valor adic. ao preco bàsico } & 3705338,607 & 44523150,78 & 21877116,47 & 13021717,19 & 40785649,6 \\
\hline & \multicolumn{5}{|c|}{ Descriçăo do Produto Nivel 80} \\
\hline Cónko & 42 & 43 & 46 & & \\
\hline PRODUTO & ADMINISTRAÇĀO & SERV. PRIV. & DUMMY & TOTAL & INDÚSTRIA \\
\hline NIVEL 80 & PÚBLICA & Ñ MERCANTIS & FINANCEIRO & & \\
\hline Valor da Produção & 70046408,75 & 4099916,566 & 0 & 652113493,7 & 299635598,3 \\
\hline Consumo Intermediário & 20884832,11 & 348528,6991 & 41122185,85 & 338828396,7 & 192256844 \\
\hline Valor adic. ao preço básico & 49161576,64 & 3751387,867 & $-41122185,85$ & 313285097 & 107378754,2 \\
\hline CODIGO & & Descri & cáo do Produto Niv & el 80 & \\
\hline PRODUTO & Serviços & Jusante1 & Jusante2 & Jusante3 & \\
\hline NNEL 80 & & & & & \\
\hline Valor da Produção & 303711661,12 & 42356191,27 & 60774367,60 & 70791802,26 & \\
\hline Consumo Intermediário & 84466451,37 & 32166645,21 & 44575678,94 & 51645062,25 & \\
\hline Valor adic. ao preco básico & 219245209,75 & 10189546,07 & 16198688,66 & 19146740,01 & \\
\hline
\end{tabular}

Fonte: Dados básicos do IBGE.

Elaborados pela autora. 
Apêndice 6.5. Estimativas a preços constantes do valor adicionado das diferentes atividades produtivas brasileiras, deflacionadas por atividades - 1992.

\begin{tabular}{|c|c|c|c|c|c|}
\hline \multirow[b]{2}{*}{ contco } & \multicolumn{5}{|c|}{ Descriçäo do Produto Nivel 80} \\
\hline & 01 & 02 & 03 & 04 & 06 \\
\hline PRODUTO & & EXTRATIVA & PETRÓLEO & MINERAL & \\
\hline NIVEL 80 & AGROPECUÁRIA & MINERAL & E GÁS & Ñ METÁLUCO & SIDERURGLA \\
\hline Valor da Produçäo & 49037227,48 & 3782203,495 & 3540863,876 & 8366327,144 & 14679732,71 \\
\hline Consumo Intermediário & 22193557,99 & 1890408,639 & 1792482,831 & 4898516,668 & 11025436,83 \\
\hline \multirow[t]{2}{*}{ Valor adic. ao preço básico } & 26843669,49 & 1891794,856 & 1748381,045 & 3467810,476 & 3654295,881 \\
\hline & \multicolumn{5}{|c|}{ Descriçąo do Produto Nivel 80} \\
\hline CóOHGO & 06 & 07 & 08 & 10 & 11 \\
\hline PRODUTO & METALÚRGIA & OUTROS & MÁQUINAS E & MATERIAL & EQUIPAMENTOS \\
\hline NNEL 80 & Ñ FERROSOS & METALÚRGICOS & TRATORES & ELÉTRICO & ELETRÓNICOS \\
\hline Valor da Produção & 4584614,51 & 10015328,47 & 12286266,54 & 4951135,011 & 4120557,5 \\
\hline Consumo Intermediário & 3392925,286 & 6574271,623 & 5841281,388 & 3103109,831 & 2450560,867 \\
\hline Valor adic. ao preco básico & 1191689,225 & 3441056,846 & 6444985,153 & 1848025,181 & 1669996,633 \\
\hline
\end{tabular}

\begin{tabular}{|c|c|c|c|c|c|}
\hline \multirow[b]{2}{*}{ COOOGO } & \multicolumn{5}{|c|}{ Descriçāo do Produto Nivel 80} \\
\hline & 12 & 13 & 14 & 15 & 16 \\
\hline PRODUTO & AUTOM.,ÓNIBUS & PEÇAS E OUTROS & MADEIRAE & CELUL, PAPEL & INDÚSTRIA \\
\hline NNEL 80 & E CAMINHŌES & VEICULOS & MOBILIÁRIO & E GRAFICA & DA BORRACHA \\
\hline Valor da Produção & 6036307,602 & 8546326,924 & 5845874,398 & 9162324,164 & 3849340,137 \\
\hline Consumo Intermediário & 4479118,117 & 5541020,355 & 3617724,113 & 6395253,623 & 2603287,942 \\
\hline Valor adic ao preço básico & 1557189,485 & 3005306,569 & 2228150,285 & 2767070,541 & 1246052,195 \\
\hline
\end{tabular}

\begin{tabular}{|c|c|c|c|c|c|}
\hline \multirow[b]{2}{*}{ CODHGO } & \multicolumn{5}{|c|}{ Descriçăo do Produto Nivel 80} \\
\hline & 17 & 18 & 19 & 20 & 21 \\
\hline PRODUTO & ELEMENTOS & REFINO DO & QUIMICOS & FARMACEUTICA & ARTIGOS \\
\hline NMEL 80 & Quimicos & PETROLLEO & DNERSOS & E VETERINARIA & PLÁstICOS \\
\hline Valor da Produção & 6913090,377 & 26155545,25 & 8574798,549 & 5045479,427 & 3911310,922 \\
\hline Consumo Intermediário & 4322046,372 & 16855911,83 & 5594337,877 & 2875729,314 & 2333987,116 \\
\hline Valor adic. ao preço básico & 2591044,004 & 9299633,418 & 2980460,672 & 2169750,113 & 1577323,807 \\
\hline
\end{tabular}

\begin{tabular}{|c|c|c|c|c|c|}
\hline \multirow{4}{*}{$\begin{array}{l}\text { CODDIGO } \\
\text { PRODUTO } \\
\text { NIVEL 80 }\end{array}$} & \multicolumn{5}{|c|}{ Descriçăo do Produto Nivel 80} \\
\hline & 22 & 23 & 24 & 25 & 28 \\
\hline & INDÜSTRIA & ARTIGOS DO & FABRICAÇĀO DE & INDÚSTRIA DO & BENEFICIAM. \\
\hline & TEXTLL & VESTUARIO & CALÇADOS & CAFE & PROD. VEGETALS \\
\hline Valor da Produção & 10244341,18 & 4347857,889 & 4258779,962 & 2292803,028 & 9893843,832 \\
\hline Consumo Intermediário & 7331284,102 & 2651299,059 & 2647870,198 & 1850733,831 & 6790491,863 \\
\hline \multirow[t]{2}{*}{ Valor adic. ao prece básico } & 2913057,08 & 1696558,831 & 1610909,765 & 442069,1974 & 3103351,97 \\
\hline & \multicolumn{5}{|c|}{ Descriçáo do Produto Nivel 80} \\
\hline CÓDGO & 27 & 28 & 29 & 30 & 31 \\
\hline $\begin{array}{l}\text { PRODUTO } \\
\text { NMEL } 80\end{array}$ & $\begin{array}{l}\text { ABATE DE } \\
\text { ANIMAIS }\end{array}$ & $\begin{array}{l}\text { INDÚSTRIA DE } \\
\text { LATICINIOS }\end{array}$ & $\begin{array}{l}\text { FABRICAÇAO DE } \\
\text { ACÚCAR }\end{array}$ & $\begin{array}{l}\text { FABRICAÇĀO DE } \\
\text { OLLOS VEGETAIS }\end{array}$ & $\begin{array}{l}\text { OUT. PRODUTOS } \\
\text { AUMENTARES }\end{array}$ \\
\hline Valor & 10481832,01 & 5040781,199 & 3212390,512 & 5511124,28 & 11360591,74 \\
\hline Consumo Intermediá & 8786593,849 & 4159721,063 & 2543892,785 & 4205746,125 & 7908525,216 \\
\hline Valor adic. ao preço básico & 1695238,157 & 881060,1364 & 668497,7269 & 1305378,155 & 3452066,519 \\
\hline
\end{tabular}


Apêndice 6.5. Continuacão.

\begin{tabular}{|c|c|c|c|c|c|}
\hline \multirow[b]{2}{*}{ cóosso } & \multicolumn{5}{|c|}{ Descricảo do Produto Nivel 80} \\
\hline & 32 & 33 & 34 & 35 & 36 \\
\hline PROOUTO & INDÚSTRLAS & & CONSTRUÇÃO & & \\
\hline NNEL 80 & ONERSAS & S.I.U.P. & CML & COMÉRCIO & TRANSPORTES \\
\hline Valor da Produçāo & 3794408,396 & 19856908,98 & 47388459,64 & 48580571,39 & 23176005,27 \\
\hline Consumo Intermediário & 1944273,404 & 11031487,12 & 23922331,49 & 19834874,94 & 12338911,77 \\
\hline Valor adic ao preço básico & 1850134,992 & 8825421,853 & 23466128,16 & 28745696,45 & 10837093,5 \\
\hline
\end{tabular}

\begin{tabular}{|c|c|c|c|c|c|}
\hline \multirow[b]{2}{*}{ CÓO\&GO } & \multicolumn{5}{|c|}{ Descriça do Produto Nivel 80} \\
\hline & 37 & 38 & 39 & 40 & 41 \\
\hline PROOUTO & & INSTITUIÇÕES & SERV. PREST. & SERV. PREST. & ALUGUEL DE \\
\hline NIVEL 80 & COMUNICAÇÕES & FINANCEIRAS & A FAMILIA & A EMPRESA & IMÓVEIS \\
\hline Valor da Produçáo & 6356219,163 & 88861779,34 & 40204267,41 & 17581807,09 & 34086322,42 \\
\hline Consumo Intermediário & 1467739,821 & 9241372,612 & 18171896,93 & 4604573,656 & 2025943,671 \\
\hline Valor adic. ao preço básico & 4888479.342 & 79620406,73 & 22032370,48 & 12977233,43 & 32060378,75 \\
\hline
\end{tabular}

\begin{tabular}{|c|c|c|c|c|c|}
\hline \multirow{3}{*}{$\begin{array}{l}\text { CODIGO } \\
\text { PRODUTO } \\
\text { NIVEL } 80\end{array}$} & \multicolumn{5}{|c|}{ Descriçąo do Produto Nivel 80} \\
\hline & 42 & 43 & 46 & & \\
\hline & $\begin{array}{l}\text { ADMINISTRAÇĀO } \\
\text { PÚBUCA }\end{array}$ & $\begin{array}{l}\text { SERV. PRIV. } \\
\text { R MERCANTIS }\end{array}$ & $\begin{array}{l}\text { DUMMY } \\
\text { FINANCEIRO }\end{array}$ & TOTAL & INDÚSTRLA \\
\hline Produçāo & 65319975,23 & 4314214,873 & $\overline{0}$ & 665569939,3 & 288051549,7 \\
\hline Consumo Intermediário & 19973068,47 & 362448,9567 & 74705677,86 & 366281727,4 & 181361660,7 \\
\hline Valor adic. ao preço básico & 45346906,76 & 3951765,916 & $-74705677,86$ & 299288211,9 & 106689888,9 \\
\hline
\end{tabular}

\begin{tabular}{|c|c|c|c|c|}
\hline \multirow{2}{*}{$\begin{array}{l}\text { COOOIGO } \\
\text { PRODUTO } \\
\text { NIVEL BO }\end{array}$} & \multicolumn{4}{|c|}{ Descriç30 do Produto Nivel 80} \\
\hline & Serviços & Jusante1 & Jusante2 & Jusante3 \\
\hline Valor da Produçāo & 328481162,19 & 43345865,23 & 60552331,37 & 70796672,55 \\
\hline Consumo Intermediário & 88020830,83 & 32659225,89 & 44185475,22 & 51516759,32 \\
\hline Valor adic. ao preço básico & 240460331,36 & 10686639,35 & 16366856,15 & 19279913,23 \\
\hline
\end{tabular}

Fonte: Dados básicos do IBGE.

Elaborados pela autora. 
Apêndice 6.6. Estimativas a preços constantes do valor adicionado das diferentes atividades produtivas brasileiras, deflacionadas por atividade - 1993.

\begin{tabular}{|c|c|c|c|c|c|}
\hline \multirow[b]{2}{*}{ cóntco } & \multicolumn{5}{|c|}{ Descriçäo do Produto Nivel 80} \\
\hline & 01 & 02 & 03 & 04 & 05 \\
\hline PRODUTO & & EXTRATIVA & PETRÓLEO & MINERAL & \\
\hline NNEL 80 & AGROPECUARIA & MINERAL & E GÁs & N METÁLICO & SIDERURGIA \\
\hline Valor da Produção & 45749602,95 & 3048430,168 & 2535819,511 & 8683257,49 & 14207124,11 \\
\hline Consumo Intermediário & 20540914,05 & 1711230,306 & 1563711,659 & 5073848,548 & 10654949,44 \\
\hline Valor adic. ao preço básico & 25208688,9 & 1337199,862 & 972107,8514 & 3609408,942 & 3552174.662 \\
\hline
\end{tabular}

\begin{tabular}{|c|c|c|c|c|c|}
\hline \multirow[b]{2}{*}{ CÓOIGO } & \multicolumn{5}{|c|}{ Descriçåo do Produto Nivel 80} \\
\hline & 06 & 07 & 08 & 10 & 11 \\
\hline PRODUTO & METALÜRGIA & OUTROS & MAQQUINAS E & MATERIAL & EQUIPAMENTOS \\
\hline NNEL 80 & ÑFERROSOS & METALÜRGICOS & TRATORES & ELETTRICO & ELETRÓNICOS \\
\hline Valor da Produçảo & 5038603,719 & 10945845,23 & 13770086,83 & 5850445,028 & 5357703,85 \\
\hline Consumo Intermediário & 3817497,724 & 6866059,442 & 5680051,948 & 3880332,775 & 3184110,303 \\
\hline Valor adic ao preço básico & 1221105,996 & 4079785,786 & 8090034,881 & 1970112,253 & 2173593,547 \\
\hline
\end{tabular}

\begin{tabular}{|c|c|c|c|c|c|}
\hline \multirow{4}{*}{$\begin{array}{l}\text { CÓDIGO } \\
\text { PRODUTO } \\
\text { NNEL } 80\end{array}$} & \multicolumn{5}{|c|}{ Descriçăo do Produto Nivel 80} \\
\hline & 12 & 13 & 14 & 15 & 16 \\
\hline & AUTOM.,ÓNIBUS & PEÇAS E OUTROS & MADEIRAE & CELUL, PAPEL & INDÚSTRLA \\
\hline & E CAMINHÓES & VEICULOS & MOBILIÁRIO & E GRAFICA & DABORRACHA \\
\hline 20 & 7608423 & 9773089,727 & 6631842,911 & 90967 & 383845 \\
\hline & & 6310 & 38 & 67 & 318 \\
\hline Valor adic. ao preço básic & 2088136,252 & 3463025,464 & 2732586,458 & 2383848,563 & 1236360,141 \\
\hline
\end{tabular}

\begin{tabular}{|c|c|c|c|c|c|}
\hline \multirow{3}{*}{$\begin{array}{l}\text { COODIGO } \\
\text { PRODUTOO }\end{array}$} & \multicolumn{5}{|c|}{ Descriçăo do Produto Nivel 80} \\
\hline & 17 & 18 & 19 & 20 & 21 \\
\hline & ELEMENTOS & REFINO DO & QUIMICOS & FARMACEUTICA & ARTIGOS \\
\hline NNEL 80 & Químicos & PETRÓLEO & DIVERSOS & E VETERINÁRIA & PLÁsticos \\
\hline Producé & 7289134,032 & 25370751,78 & 8188461,221 & 5459563,219 & 4031859,15 \\
\hline Consumo Interm & 3805564,457 & 13135071,63 & 5374281,859 & 2934541,414 & 2303727,381 \\
\hline Valor adic. ao preço básico & 3483569,575 & 12235680,15 & 2814179,362 & 2525021,805 & 1728131,769 \\
\hline
\end{tabular}

\begin{tabular}{|c|c|c|c|c|c|}
\hline \multirow{4}{*}{$\begin{array}{l}\text { COOIGO } \\
\text { PRODUTO } \\
\text { NNEL } 80\end{array}$} & \multicolumn{5}{|c|}{ Descriçăo do Produto Nivel 80} \\
\hline & 22 & 23 & 24 & 25 & 28 \\
\hline & INDÚSTRIA & ARTIGOS DO & FABRICAÇĀO DE & INDÚSTRIA DO & BENEFICIAM. \\
\hline & TEXXIL & VESTUÁRIO & CALÇADOS & CAFE & PROD. VEGETAIS \\
\hline Valor da Produção & 10100049,34 & 4585261,235 & 4156623,232 & 3066476,989 & 10819389,81 \\
\hline Consumo Intermediário & 7030298,075 & 2824333,356 & 2605050,843 & 2263418,122 & 7502496,078 \\
\hline \multirow{2}{*}{ Valor adic. ao preço básico } & 3069751,265 & 1760927,879 & 1551572,389 & 803058,8662 & 3316893,728 \\
\hline & \multicolumn{5}{|c|}{ Descriçăo do Produto Nivel 80} \\
\hline CÓDtGo & 27 & 28 & 28 & 30 & 31 \\
\hline PRODUTO & ABATE DE & INDÚSTRIA DE & FABRICAÇĀO DE & FABRICAÇÃO DE & OUT. PRODUTOS \\
\hline NIVEL 80 & ANIMAIS & LATICINIOS & ACQÚCAR & OLEOS VEGETAIS & ALIMENTARES \\
\hline Produção & 10856878,78 & 4388196,359 & 3033917,42 & 5639416,806 & 12293281,53 \\
\hline Consumo Intermediário & 8734894,29 & 3602865,54 & 2277820,596 & 4638593,401 & 8569578,014 \\
\hline Valor adic. ao preço básico & 2121984,494 & 785330,8181 & 756096,8235 & 1000823,405 & 3723703,516 \\
\hline
\end{tabular}


Apêndice 6.6. Continuaçāo.

\begin{tabular}{|c|c|c|c|c|c|}
\hline \multirow[b]{2}{*}{ COONGO } & \multicolumn{5}{|c|}{ Descrifsao do Produto Nivel 80} \\
\hline & 32 & 33 & 34 & 35 & 36 \\
\hline PRODUTO & INDÚSTRIAS & & CONSTRUÇĀO & & \\
\hline NIVL 80 & OIVERSAS & S.L.U.P. & CMVL & COMÉRCIO & TRANSPORTES \\
\hline Valor da Produção & 4125028,305 & 19816921,54 & 49887573,44 & 52445926,97 & 24191635,36 \\
\hline Consumo Intermediário & 2254007,322 & 10458766,3 & 24239475,64 & 22957029,95 & 13169116,27 \\
\hline \multirow[t]{2}{*}{ Valor adic. ao preço básico } & 1871020,983 & 9358155,241 & 25648097,8 & 29488897,02 & 11022519,09 \\
\hline & \multicolumn{5}{|c|}{ Descriçăo do Produto Nivel 80} \\
\hline CÓDIGO & 37 & 38 & 38 & 40 & 41 \\
\hline PRODUTO & & INSTrTUIÇŌES & SERV. PREST. & SERV. PREST. & ALUGUEL DE \\
\hline NNEL 80 & COMUNICAÇÕES & FINANCEIRAS & A FAMILIA & A EMPRESA & IMÓVEIS \\
\hline Valor da Produção & 7373304,498 & 114093838,7 & 41542533,65 & 19181016,59 & 23712748,63 \\
\hline Consumo Intermediário & 1868321,798 & 10329266,29 & 18143787,34 & 5010657,239 & 2014129,897 \\
\hline Valor adic. ao preço básico & 5504982,699 & 103764572,4 & 23398746,31 & 14170359,35 & 21698618,74 \\
\hline
\end{tabular}

\begin{tabular}{|c|c|c|c|c|c|}
\hline \multirow[b]{2}{*}{ CODKGO } & \multicolumn{5}{|c|}{ Descrição do Produto Nivel 80} \\
\hline & 42 & 43 & 46 & & \\
\hline PRODUTO & ADMINISTRAÇĀO & SERV. PRIV. & DUMMY & TOTAL & INDÚSTRLA \\
\hline NIVEL 80 & PÚBLICA & N MERCANTIS & FINANCEIRO & & \\
\hline Valor da Produção & 69320962,12 & 4500626,391 & 0 & 701606886,2 & 299494690,4 \\
\hline Consumo Intermediário & 23464456,5 & 390769,3497 & 98167656,33 & 398087314,9 & 182031209,9 \\
\hline Valor adic. ao preco básico & 45856505,61 & 4109857,041 & $-98167656,33$ & 303519571,4 & 117463480,5 \\
\hline código & \multicolumn{5}{|c|}{ Descriçảo do Produto Nivet 80} \\
\hline PRODUTO & Serviços & Jusante1 & Jusante2 & Jusante3 & \\
\hline \multicolumn{6}{|l|}{ NNEL 80} \\
\hline Valor da Produção & 356362592,92 & 45093410,20 & 64018534,64 & 74118583,98 & \\
\hline Consumo Intermediário & 97347534,62 & 32825652,49 & 45294486,95 & 52324785,03 & \\
\hline Valor adic. ao preço básico & 259015058,29 & 12267757,71 & 18724047,68 & 21793798,95 & \\
\hline
\end{tabular}

Fonte: Dados básicos do IBGE. 
Apêndice 6.7. Estimativas a preços constantes do valor adicionado das diferentes atividades produtivas brasileiras, deflacionadas por atividade - 1994 .

\begin{tabular}{|c|c|c|c|c|c|}
\hline \multirow[b]{2}{*}{ cótGo } & \multicolumn{5}{|c|}{ Descriçäo do Produto Nivel 80} \\
\hline & 01 & 02 & 03 & 04 & 05 \\
\hline PRODUTO & & EXTRATIVA & PETRóleo & MINERAL & \\
\hline NVEL 80 & AGROPECUARIA & MINERAL & E GAS & Ñ METÁLICO & SIDERURGIA \\
\hline Valor da Produção & 50344517,08 & 3544305,323 & 2818364,309 & 9035088,623 & 14160340,55 \\
\hline Consumo Intermediário & 19890015 & 2019856 & 1766210 & 5052375 & 10854448,36 \\
\hline Valor adic. ao preço básico & 30454502,08 & 1524449,323 & 1052154,309 & 3982713,623 & 3305892,181 \\
\hline
\end{tabular}

\begin{tabular}{|c|c|c|c|c|c|}
\hline \multirow[b]{2}{*}{ COOLGO } & \multicolumn{5}{|c|}{ Descriçăo do Produto Nivel 80} \\
\hline & 06 & 07 & 08 & 10 & 11 \\
\hline PRODUTO & METALÚRGIA & OUTROS & MÁQUINAS E & MATERIAL & EQUIPAMENTOS \\
\hline NMEL 80 & NFERROSOS & METALURGICOS & TRATORES & ELETRICO & ELETRÓNICOS \\
\hline Valor da Produçāo & 5297062,827 & 11520823,09 & 14414539 & 6790745 & 7002093 \\
\hline Consumo Intermediário & 3736866 & 7092324 & 6151866 & 4601548 & 4091506 \\
\hline Valor adic. ao preço básico & 1560196,827 & 4428499,091 & 8262673 & 2189197 & 2910587 \\
\hline
\end{tabular}

\begin{tabular}{|c|c|c|c|c|c|}
\hline \multirow[b]{2}{*}{ COOHGO } & \multicolumn{5}{|c|}{ Descrição do Produto Nivel 80} \\
\hline & 12 & 13 & 14 & 15 & 16 \\
\hline PRODUTO & AUTOM.,ÓNIBUS & EÇAS E OUTROS & MADEIRAE & CELUL., PAPEL & INDÚSTRIA \\
\hline NIVEL 80 & E CAMINHÓES & VEICULOS & MOBILIÁRIO & E GRAFICA & DA BORRACHA \\
\hline Valor da Produgão & 8959781,909 & 10689515,09 & 6988581 & 10235940,27 & 3903514,639 \\
\hline Consumo Intermediário & 6384094,362 & 6894999 & 4065703 & 7443930 & 2651495 \\
\hline Valor adic. ao preco básico & 2575687,547 & 3794516,091 & 2922878 & 2792010,273 & 1252019,639 \\
\hline
\end{tabular}

\begin{tabular}{|c|c|c|c|c|c|}
\hline \multirow[b]{2}{*}{ CODIGO } & \multicolumn{5}{|c|}{ Descrição do Produto Nivel 80} \\
\hline & 17 & 18 & 19 & 20 & 21 \\
\hline PRODUTO & ELEMENTOS & REFINO DO & Químicos & FARMACEUUTICA & ARTIGOS \\
\hline NAVEL 80 & Quimicos & PETROLLO & DIVERSOS & E VETERINARIA & PLÁSTICOS \\
\hline Valor da Produção & 8042007,068 & 27387088,51 & 9315190,141 & 5771183,939 & 4299215,455 \\
\hline Consumo Intermediário & 4519630 & 15627589 & 6419775 & 3149314 & 2559417 \\
\hline Valor adic. ao preco básico & 3522377,068 & 11759499,51 & 2895415,141 & 2621869,939 & 1739798,455 \\
\hline
\end{tabular}

\begin{tabular}{|c|c|c|c|c|c|}
\hline \multirow[b]{2}{*}{ CóOtGo } & \multicolumn{5}{|c|}{ Descrlęžo do Produto Nivel 80} \\
\hline & 22 & 23 & 24 & 25 & 28 \\
\hline PRODUTO & INDÚSTRIA & ARTIGOS DO & FABRICAÇÃO DE & INDÚSTRIA DO & BENEFICIAM. \\
\hline NIVEL 80 & TEXTL & VESTUARIO & CALÇADOS & CAFE & PROD. VEGETAIS \\
\hline Valor da Produção & 10276352,56 & 5147676,567 & 3518950,368 & 3959181,074 & 10557933,25 \\
\hline Consumo Intermediário & 7397401,546 & 3147682 & 2282875 & 2990056,999 & 7727365,636 \\
\hline \multirow[t]{2}{*}{ Valor adic. ao preço básico } & 2878951,016 & 1999994,567 & 1236075,368 & 969124,075 & 2830567,616 \\
\hline & \multicolumn{5}{|c|}{ Descrlyăo do Produto Nivet 80} \\
\hline cótgo & 27 & 28 & 29 & 30 & 31 \\
\hline PRODUTO & ABATE DE & INDÚSTRIA DE & FABRICAÇÃO DE & FABRICAÇĀO DE & OUT. PRODUTOS \\
\hline NIVEL 80 & ANIMAIS & LATICINIOS & AÇÚCAR & OLLEOS VEGETAIS & ALIMENTARES \\
\hline Valor da Produção & 9705980,974 & 3943750,914 & 3362792,182 & 6859430,823 & 13528652,97 \\
\hline Consumo Intermediário & 7829080 & 3239858,636 & 2591646 & 5679143 & 9652351,636 \\
\hline Valor adic. ao preço básico & 1876900,974 & 703892,278 & 771146,182 & 1180287,823 & 3876301,33 \\
\hline
\end{tabular}


Apêndice 6.7. Continuação.

\begin{tabular}{|c|c|c|c|c|c|}
\hline \multirow[b]{2}{*}{ cótgo } & \multicolumn{5}{|c|}{ Descrlęăo do Produto Nivel 80} \\
\hline & 32 & 33 & 34 & 35 & 36 \\
\hline PRODUTO & INDÚSTRIAS & & CONSTRUÇÃO & & \\
\hline NNEL 80 & ONERSAS & S.I.U.P. & CML & COMÉRCIO & TRANSPORTES \\
\hline Valor da Produçảo & 4236729,545 & 18890645 & 51917740 & 47627317,85 & 23422677,09 \\
\hline Consumo Intermediário & 2277309 & 9521768 & 23425868,09 & 18382471,64 & 12622463,81 \\
\hline \multirow[t]{2}{*}{ Valor adic ao preço básico } & 1959420,545 & 9368877 & 28491871,91 & 29244846,21 & 10800213,28 \\
\hline & \multicolumn{5}{|c|}{ Descriçåo do Produto Nivel 80} \\
\hline CODIGO & 37 & 38 & 38 & 40 & 41 \\
\hline PRODUTO & & INSTITUIÇŐES & SERV. PREST. & SERV. PREST. & ALUGUEL DE \\
\hline NNEL 80 & COMUNICAÇŐES & FINANCEIRAS & A FAMILIA & Ả EMPRESA & IMÓVEIS \\
\hline Valor da Produçảo & 6048882 & 58873368 & 38345356,36 & 16539528 & 23422740,91 \\
\hline Consumo Intermediário & 1544084 & 9699286 & 17171183,09 & 4478073 & 2046141 \\
\hline Valor adic. ao preco básico & 4504798 & 49174082 & 21174173,27 & 12061455 & 21376599,91 \\
\hline
\end{tabular}

\begin{tabular}{|c|c|c|c|c|c|}
\hline \multirow[b]{2}{*}{ CODIGO } & \multicolumn{5}{|c|}{ Descriçäo do Produto Nivel 80} \\
\hline & 42 & 43 & 46 & & \\
\hline PRODUTO & ADMINISTRAÇÃO & SERV. PRIV. & DUMMY & TOTAL & INDÚSTRIA \\
\hline NMEL 80 & PÚBLICA & N MERCANTIS & FINANCEIRO & & \\
\hline Valor da Produção & 68963905 & 4150174 & 0 & 653819662,3 & 316081196 \\
\hline Consumo Intermediário & 21940163 & 373628 & 43620153 & 344613012,8 & 192845351,3 \\
\hline Valor adic. ao preço básico & 47023742 & 3776546 & -43620153 & 309206649,5 & 123235844,7 \\
\hline
\end{tabular}

\begin{tabular}{|c|c|c|c|c|}
\hline \multirow{2}{*}{$\begin{array}{l}\text { COODIGO } \\
\text { PRODUTO } \\
\text { NNEL } 80\end{array}$} & \multicolumn{4}{|c|}{ Descriçảo do Produto Nivel 80} \\
\hline & Serviços & Jusante1 & Jusante2 & Jusante3 \\
\hline Valor da Produçāo & 287393949,21 & 46431076,29 & 66948310,25 & 77224662,82 \\
\hline Consumo intermediário & 88257493,54 & 34576780,27 & 48294834,91 & 55692236,45 \\
\hline Valor adic. ao preco básico & 199136455,67 & 11854296,02 & 18653475,35 & 21532426,36 \\
\hline
\end{tabular}

Fonte: Dados básicos do IBGE.

Elaborados pela autora. 


\section{APÊNDICE 7}

\section{Valor Adicionado do Complexo Agroindustrial Brasileiro 1980-94}

A 7.1 Valor adicionado a preços constantes do Complexo Agroindustrial Brasileiro 1980-94. (R\$ mil)

A 7.2 Valor adicionado a preços constantes do Complexo Agroindustrial Brasileiro 1980-94. (US\$ mil)

A 7.3 Índice de Produto Real (Base $1980=100$ ), segundo os agregados do Complexo Agroindustrial Brasileiro 1980-94.

A 7.4 Índice de Variação do Produto Real, segundo os agregados do Complexo Agroindustrial Brasileiro 1980-94. 


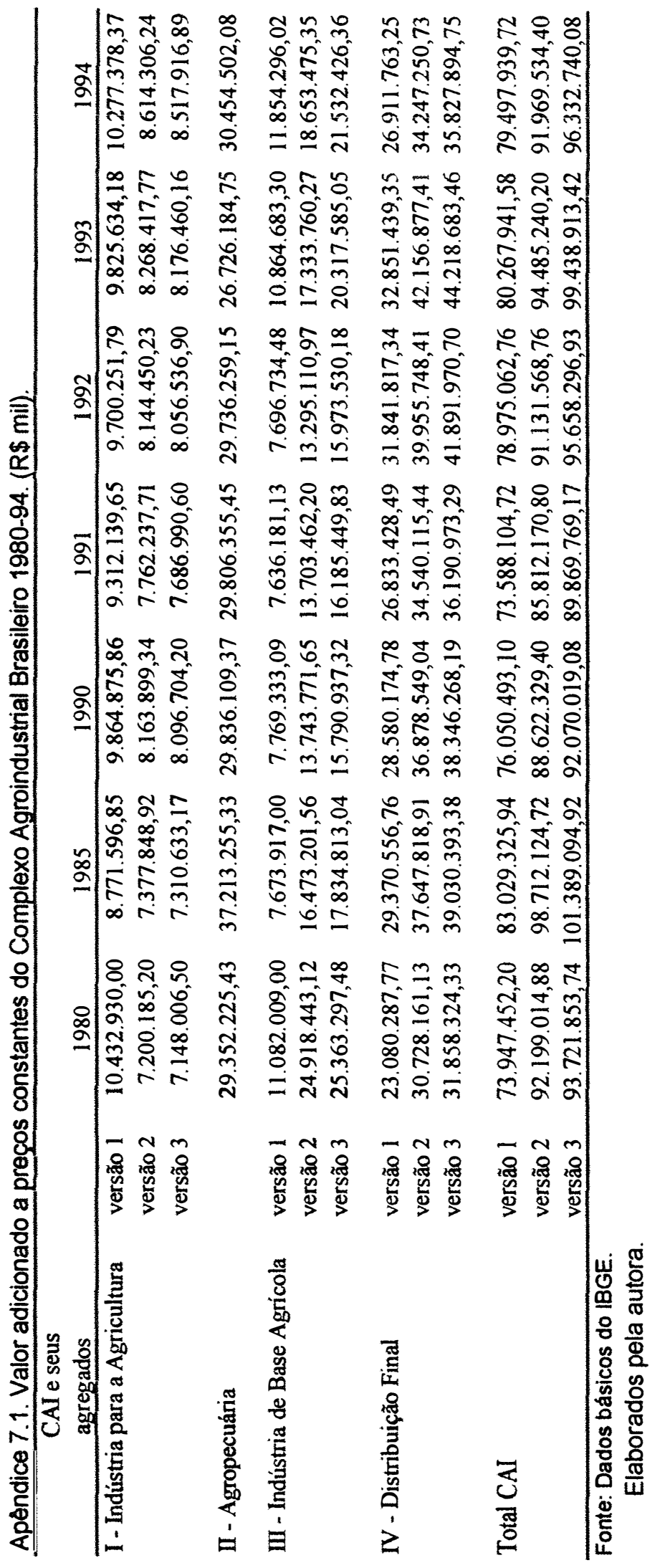




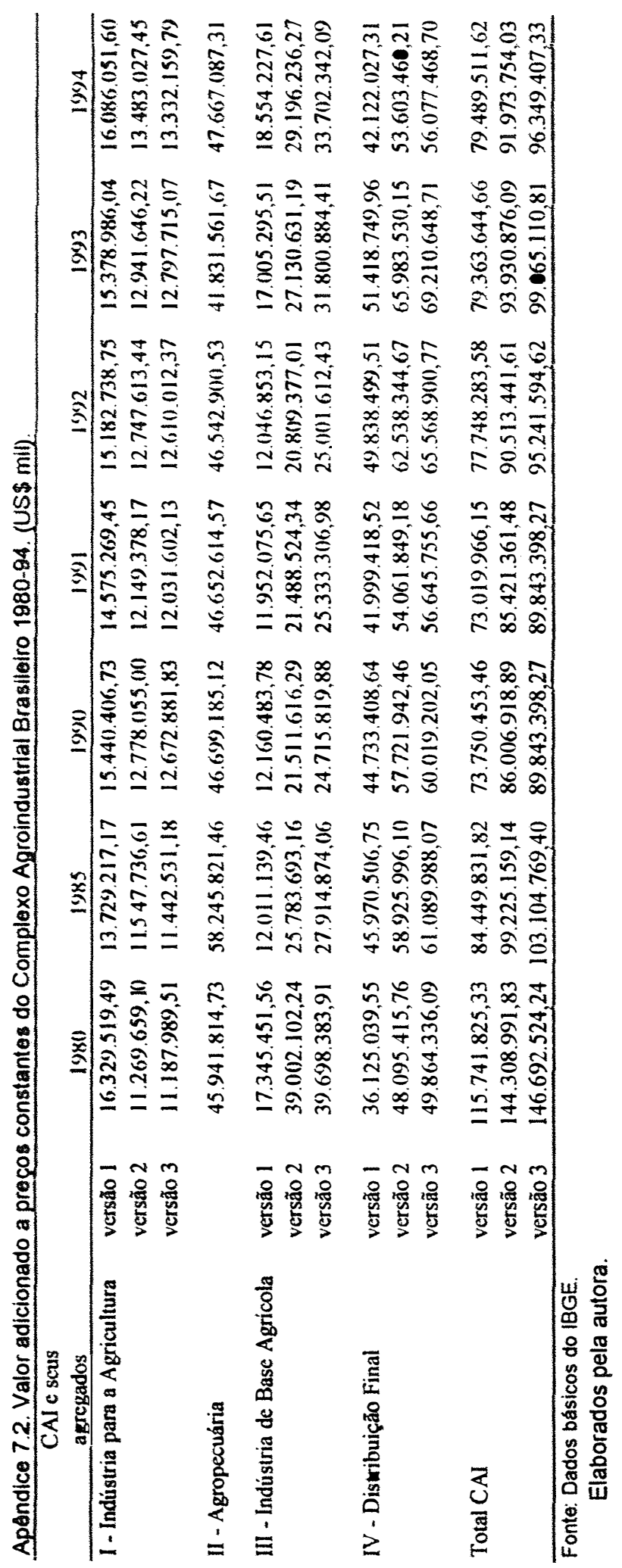




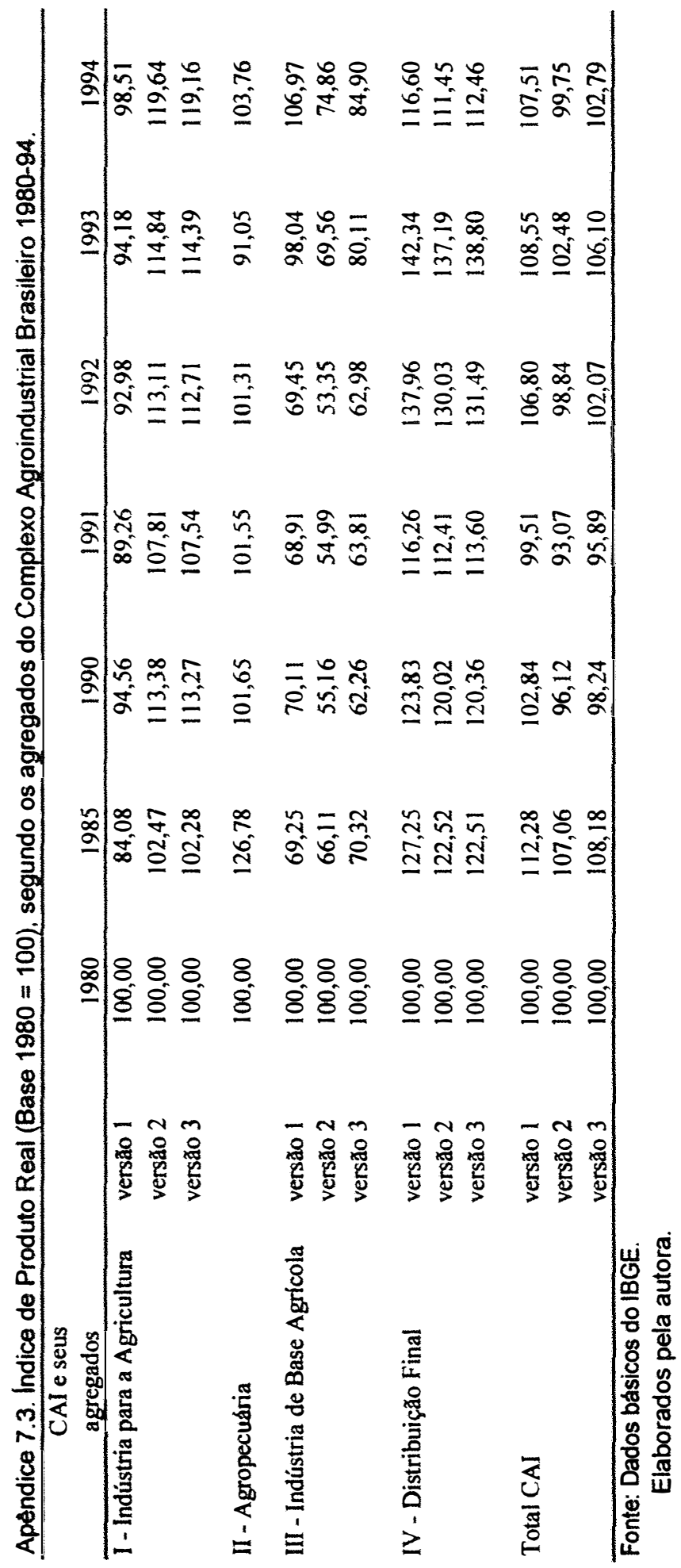




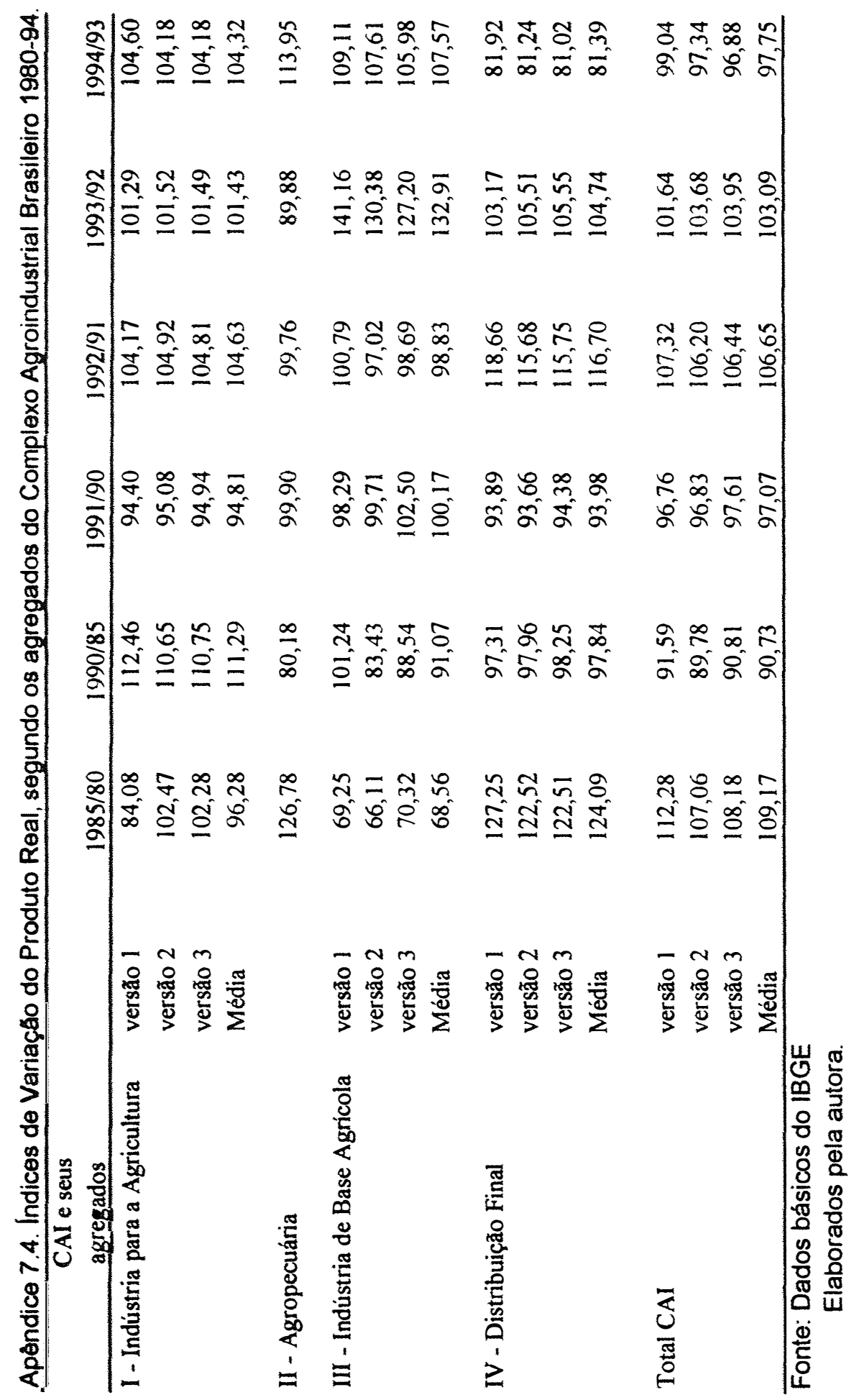




\section{APÊNDICE 8}

Valor Adicionado segundo os ramos e as classes de atividade econômica 1980-94

A 8.1 Valor adicionado a preços constantes, segundo os ramos e as classes de atividade econômica 1980-94. (R\$ mil)

A 8.2 Valor adicionado a preços constantes, segundo os ramos e as classes de atividade econômica 1980-94. (US\$ mil) 


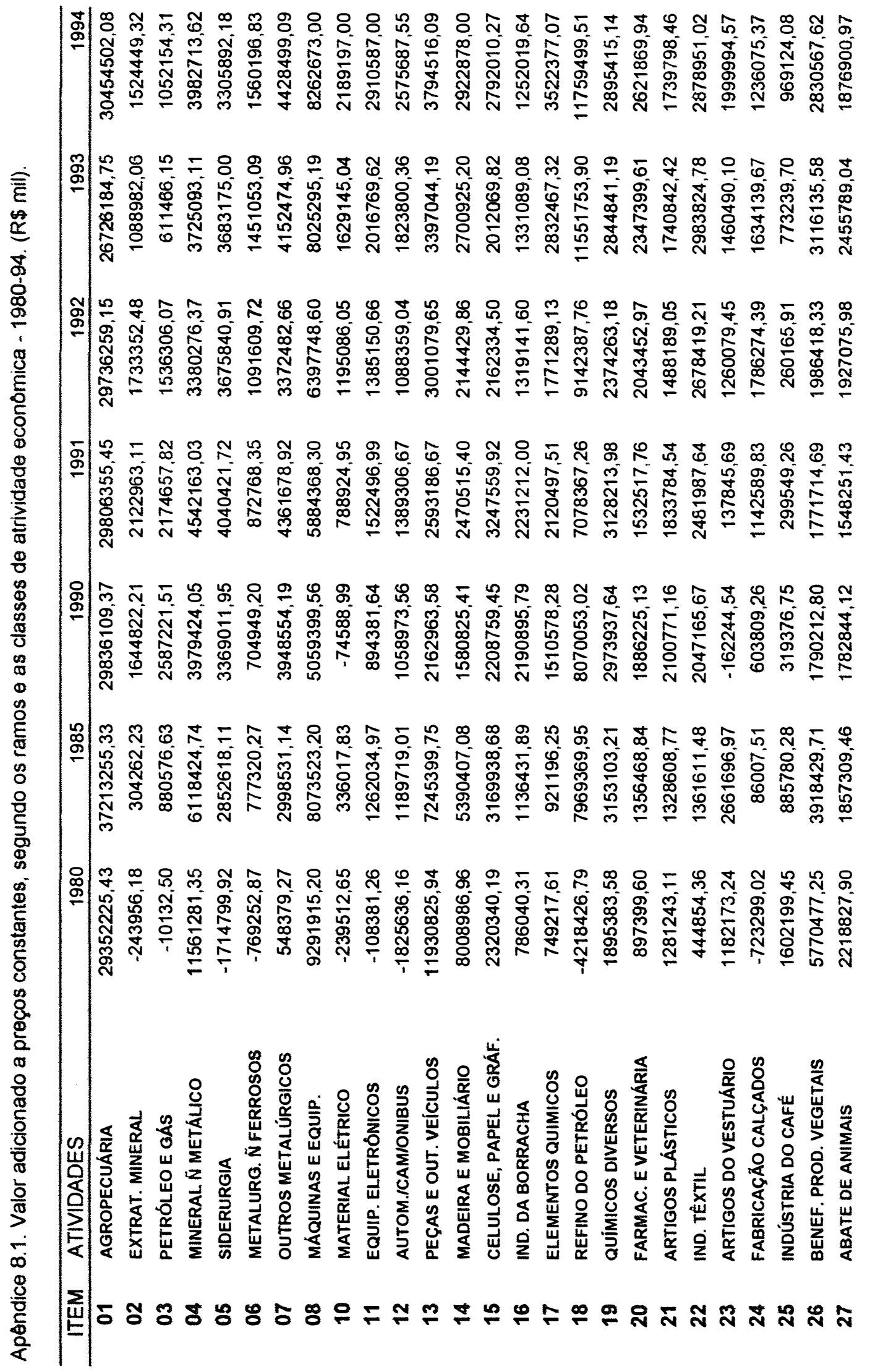




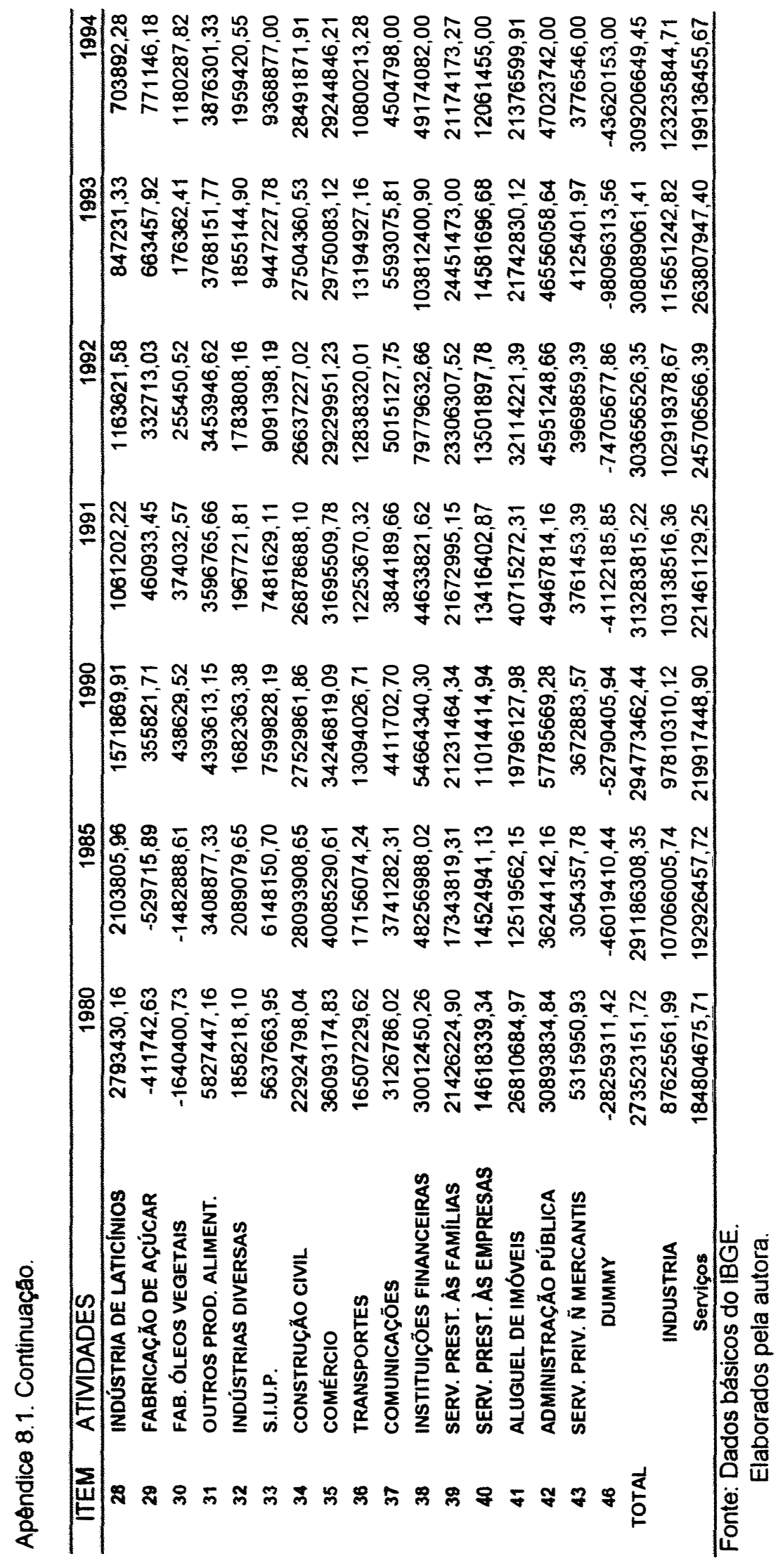




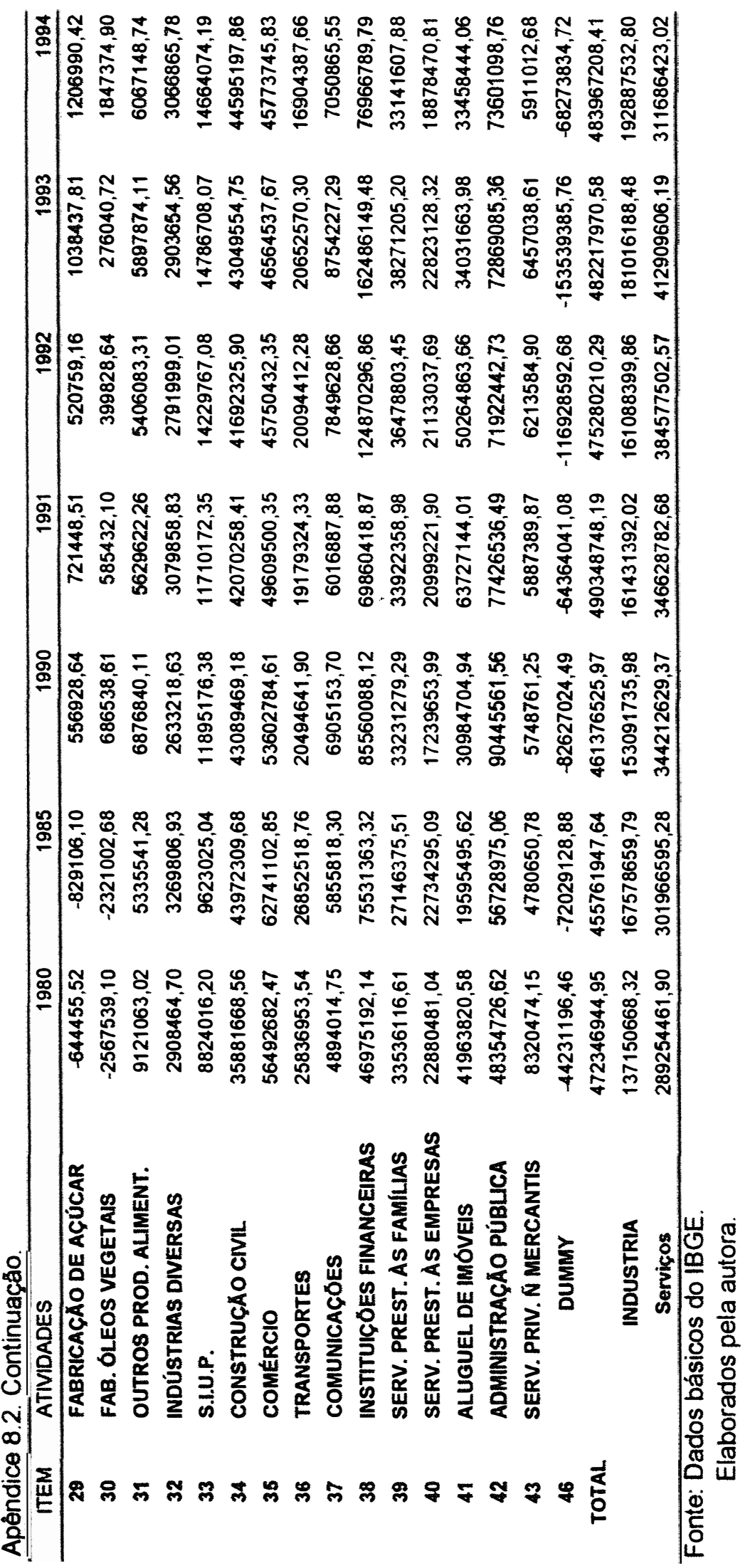




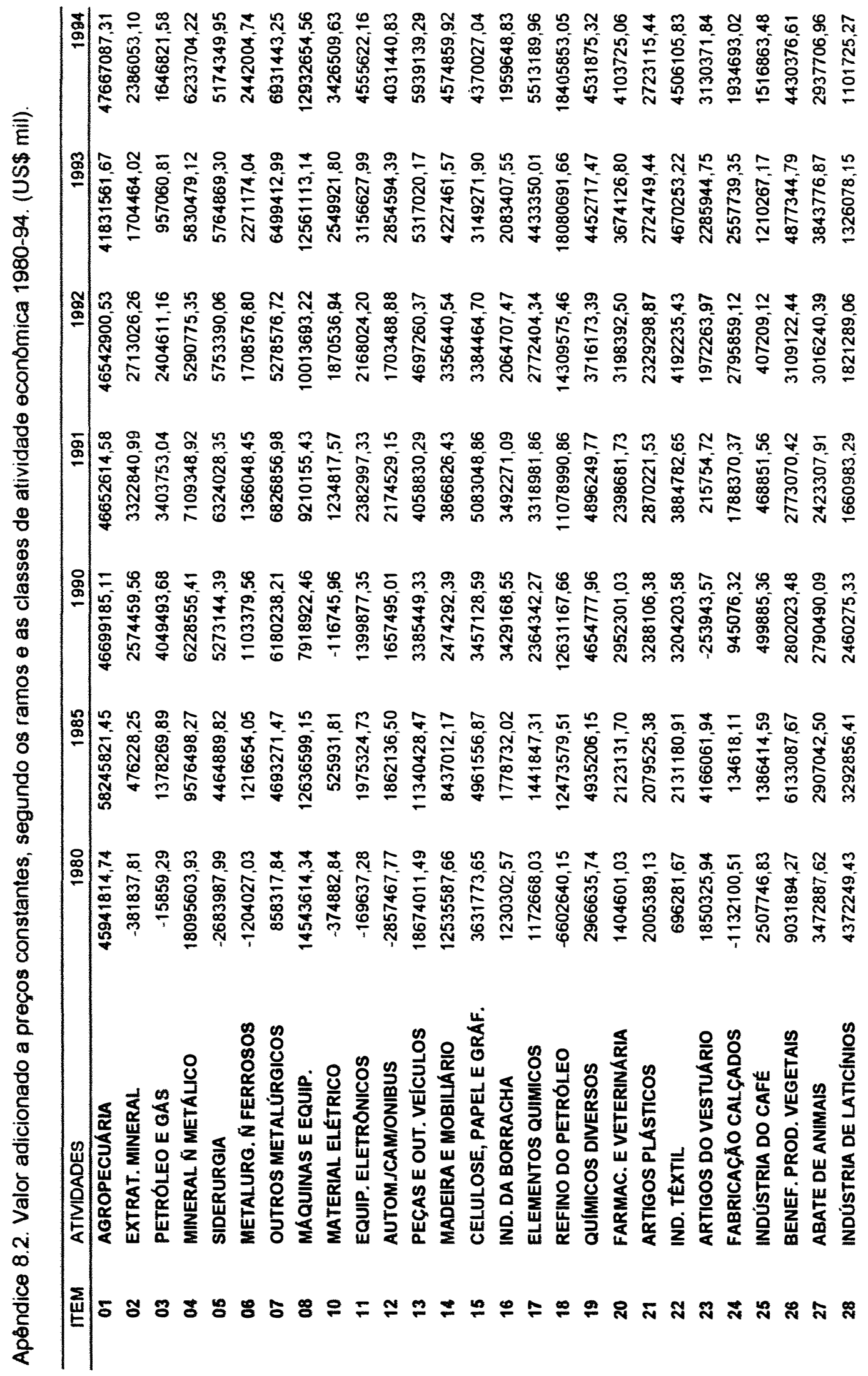




\section{APÊNDICE 9 \\ Evolução da produção da agropecuária brasileira - 1980-94}

A 9.1 Produção a preços constantes da agropecuária brasileira por produtos,

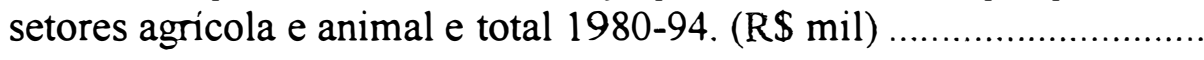

A 9.2 Produção a preços constantes da agropecuária brasileira por produtos, setores agrícola e animal e total 1980-94 (US\$ mil)

A 9.3 Índice de Produção a preços constantes da agropecuária brasileira por produtos, setores agricola e animal e total 1980-84. (Base 1980=100)

A 9.4 Índice de Variação da Produção a preços constantes da agropecuária brasileira por produtos, setores agrícola e animal e total 1980-84. 


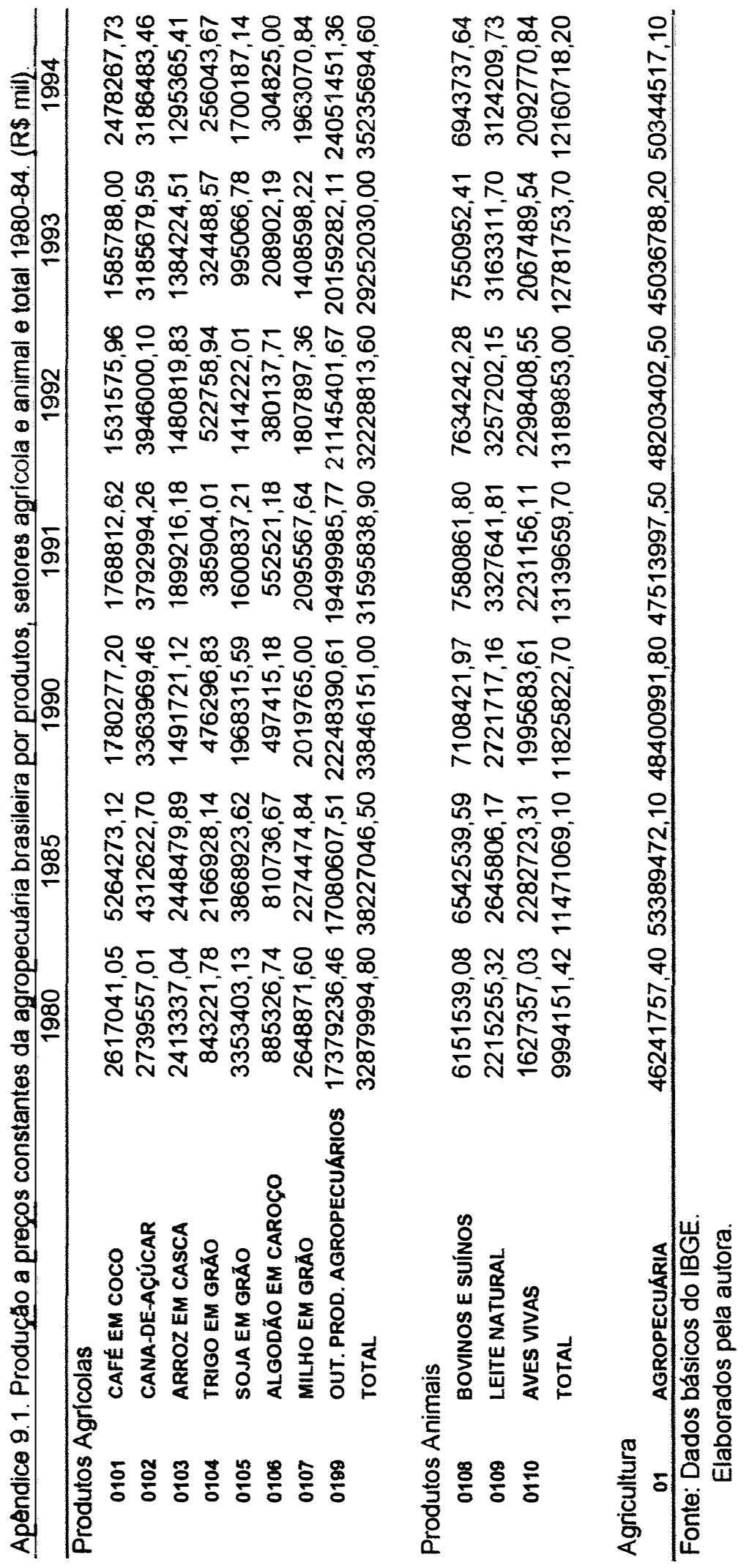




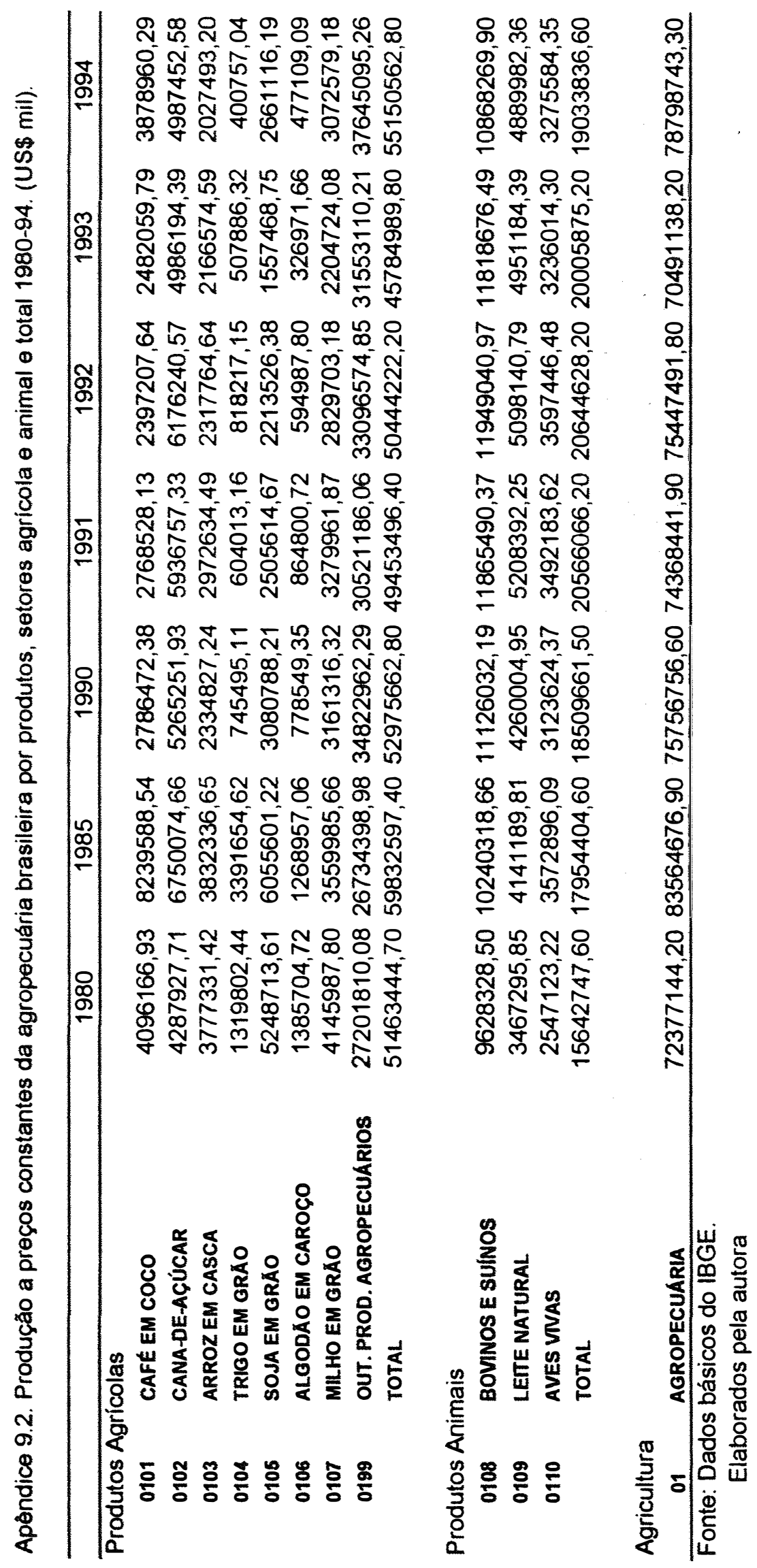




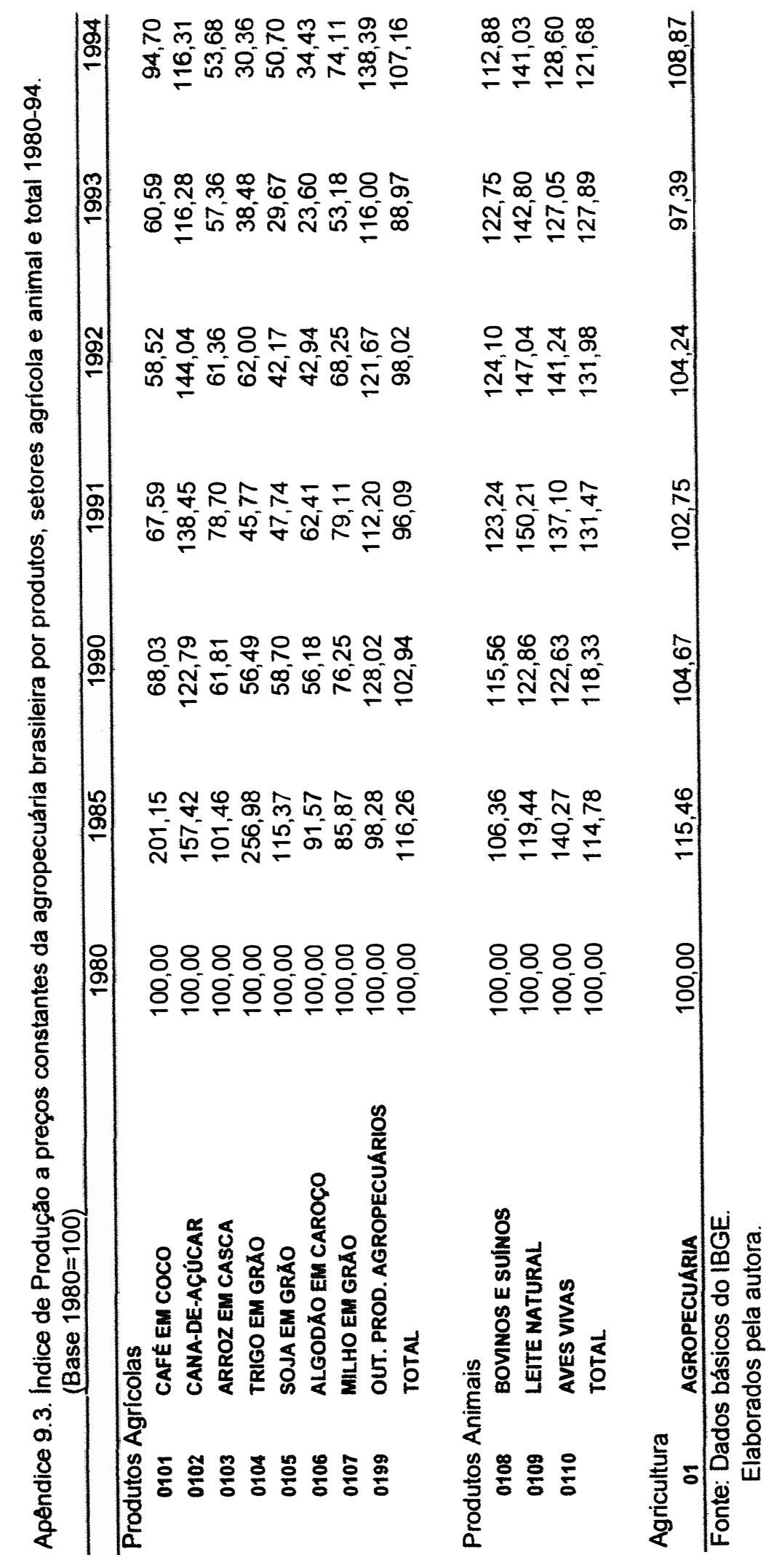




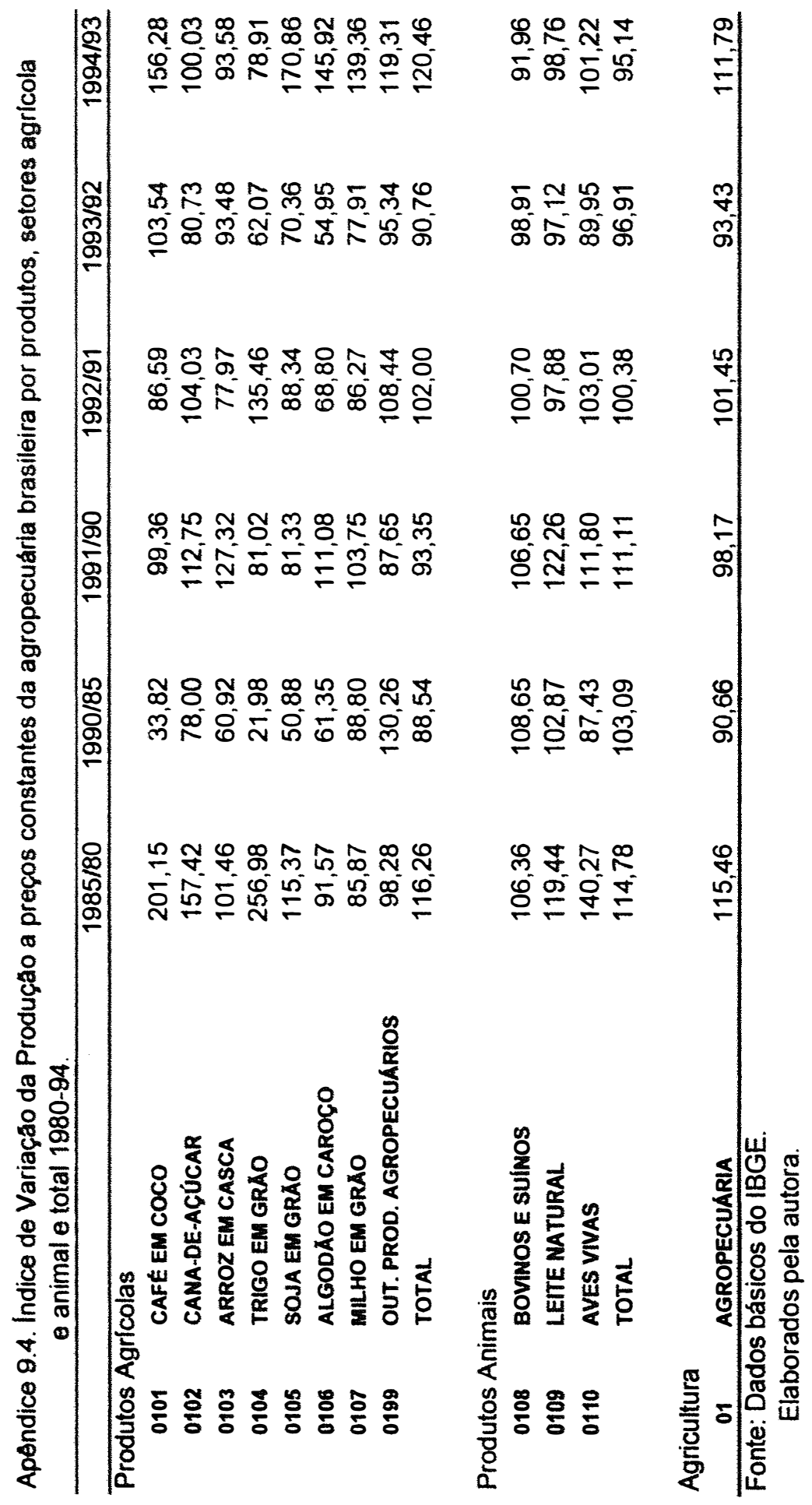




\section{APÊNDICE 10 \\ Evolução da produção das principais indústrias vinculadas a agropecuária brasileira - 1980-94}

A 10.1 Produção a preços constantes das principais indústrias vinculadas ao setor agricola brasileiro, por atividades e produtos 1980-94 (R\$ mil)

A 10.2 Produção a preços constantes das principais indústrias vinculadas ao setor agricola brasileiro, por atividades e produtos 1980-94 (US\$ mil)

A 10.3 Índice de Produção a preços constantes das principais indústrias vinculadas ao setor agrícola brasileiro, por atividades e produtos 1980-94. (Base $1980=100)$

A 10.4 Índice de Variação da Produção a preços constantes das principais indústrias vinculadas ao setor agrícola brasileiro, por atividades e produtos 1980-94. 


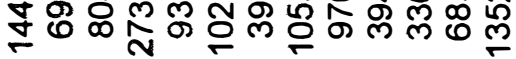

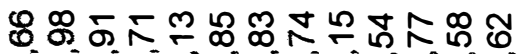
क

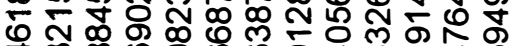
雨 议

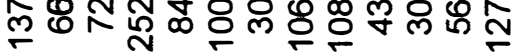
ฟูษ พ \&

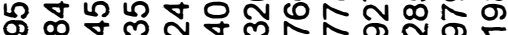

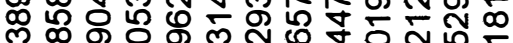

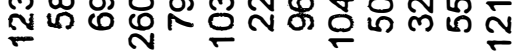

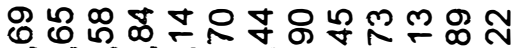
బิ์ N

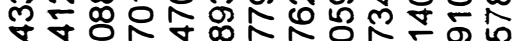

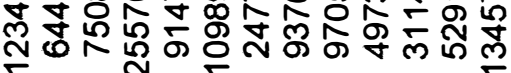

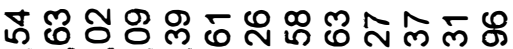

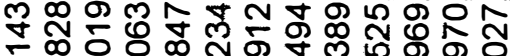

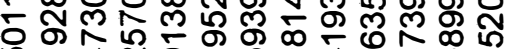

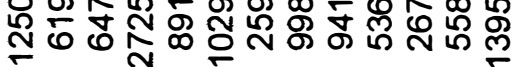

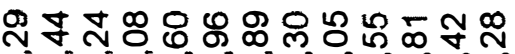
సี่

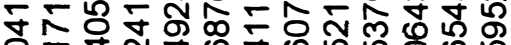

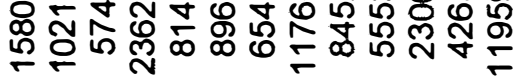

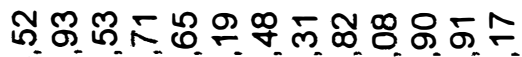

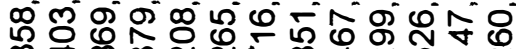

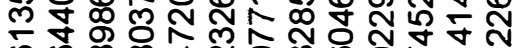
๒ ळ ஐ 乌্ল

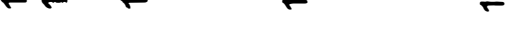

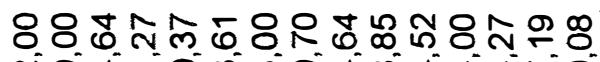

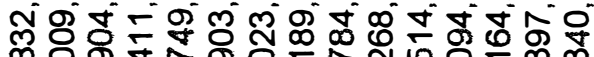

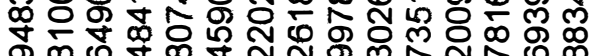

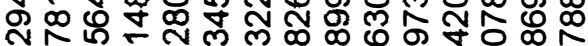

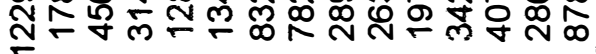
N

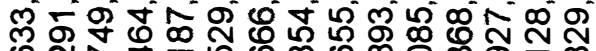

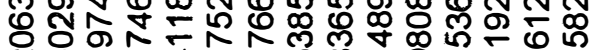

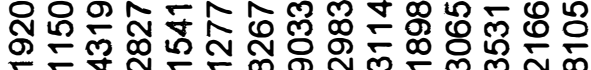

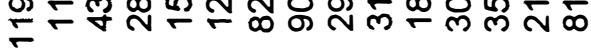

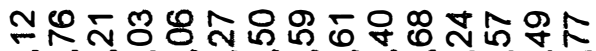
๒ั5

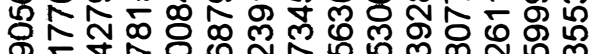

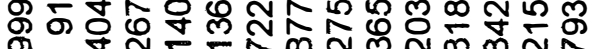
นึ้ ชิ์

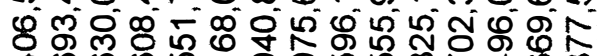
응 0 응

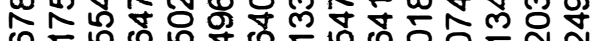

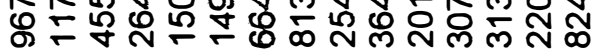

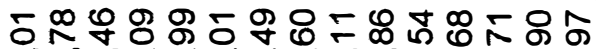

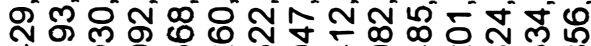

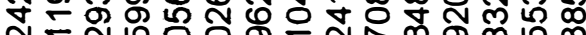
సัธ

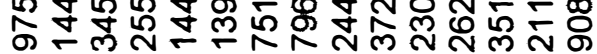

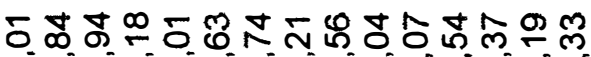
రำ ర్ల \%్ల

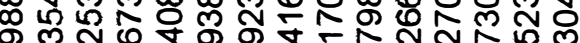

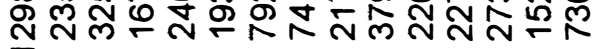

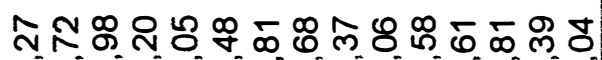

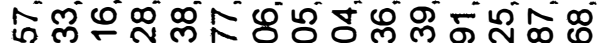
₹

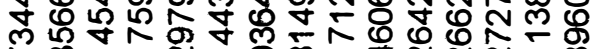

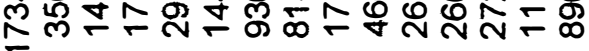

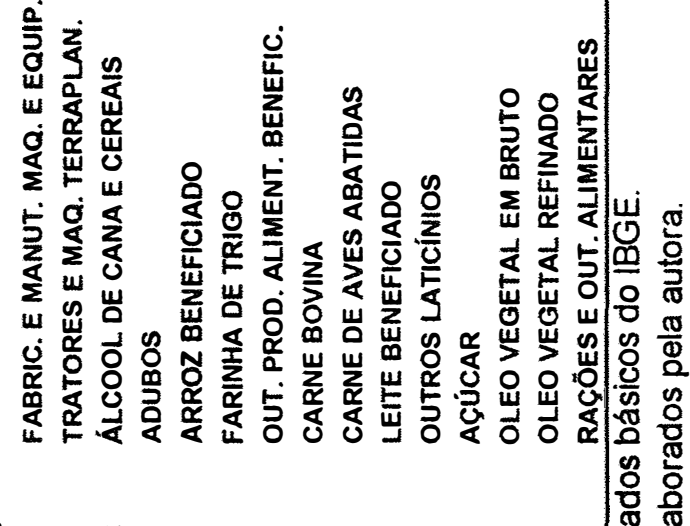




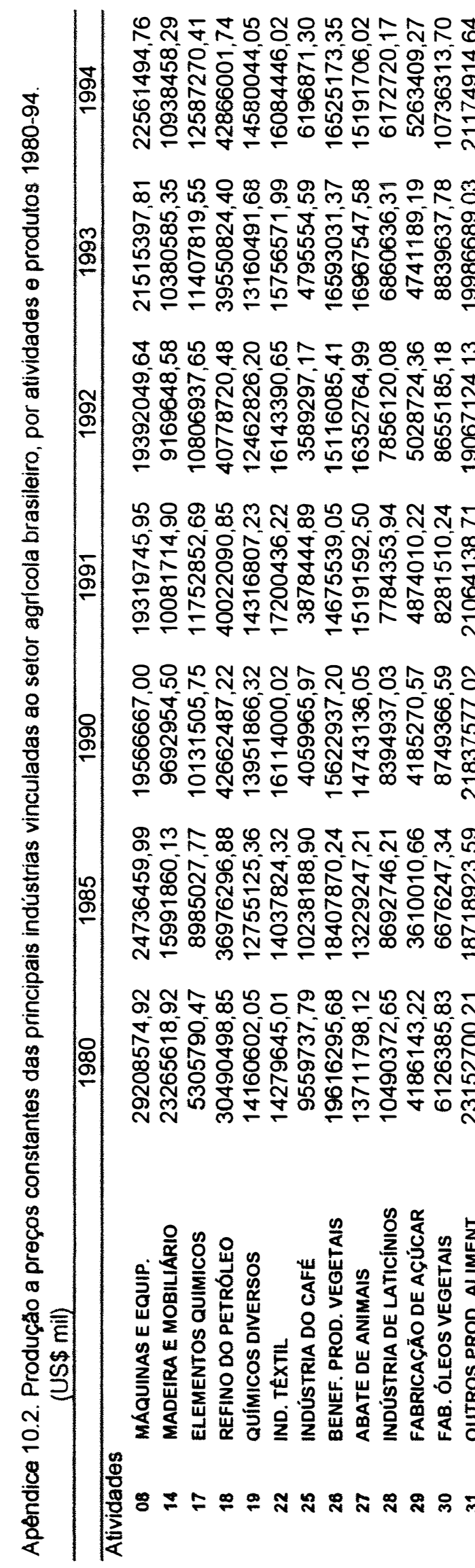

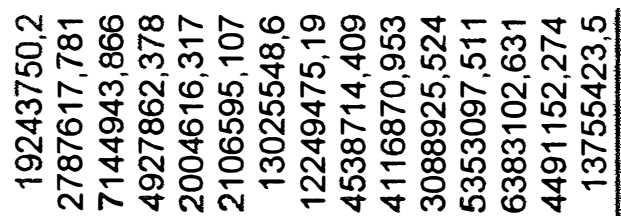

ஸீำㅇำ 녕

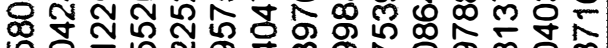

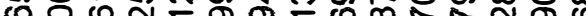
ळ

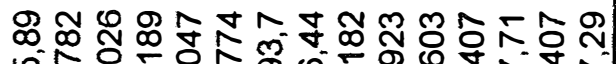
אÑ

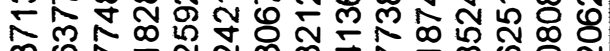
ถั W

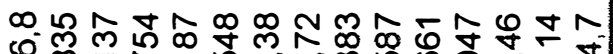
๑ ผ 舫

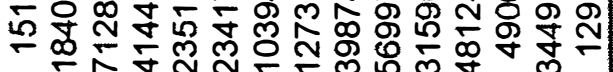
ฺ พ m N

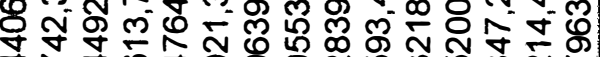
ช

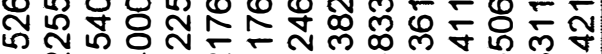
는

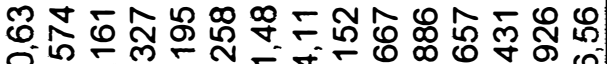
क

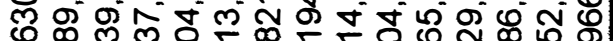
O

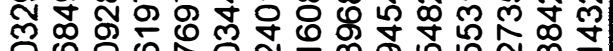

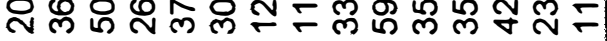

幽 过 今 ఫ。 六

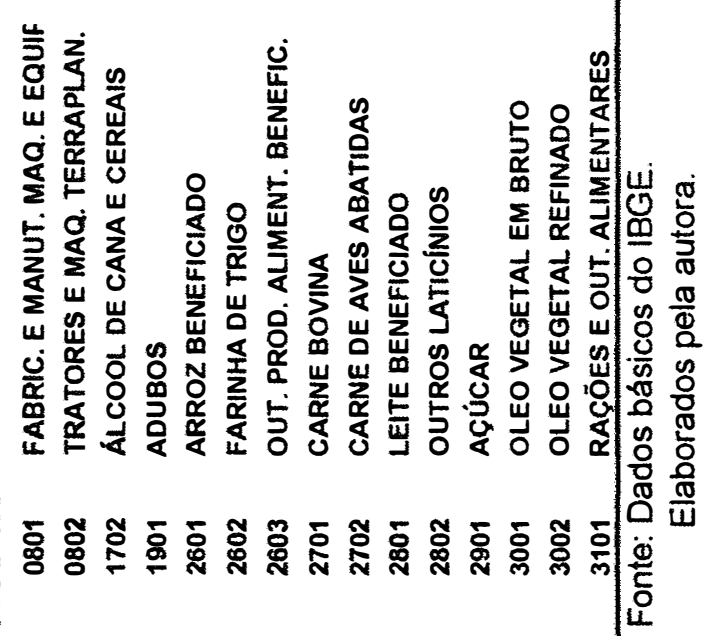


0

| ヘ์

ஐ

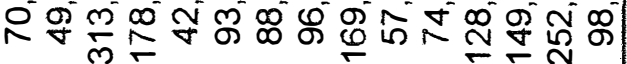

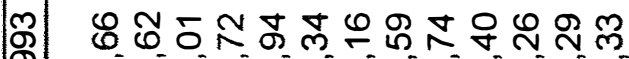

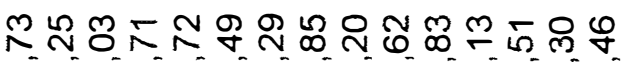
হं

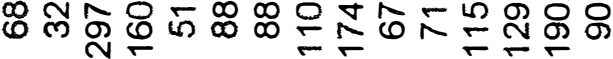

ন⿵ ๒

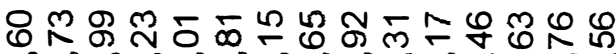

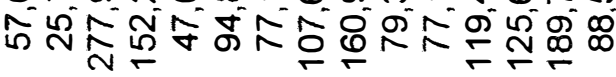

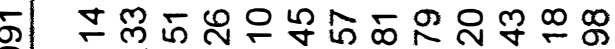
৫ัす

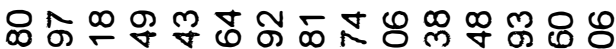

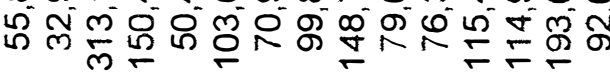

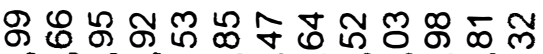

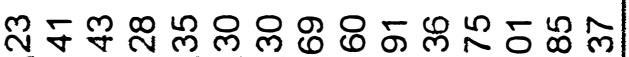
๒ั ๒

ஜ চ

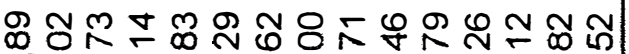

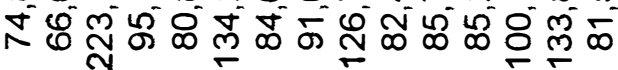

@

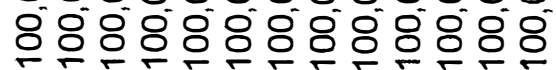

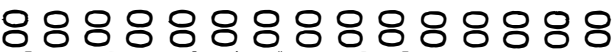

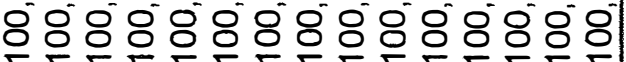
(1) (1)
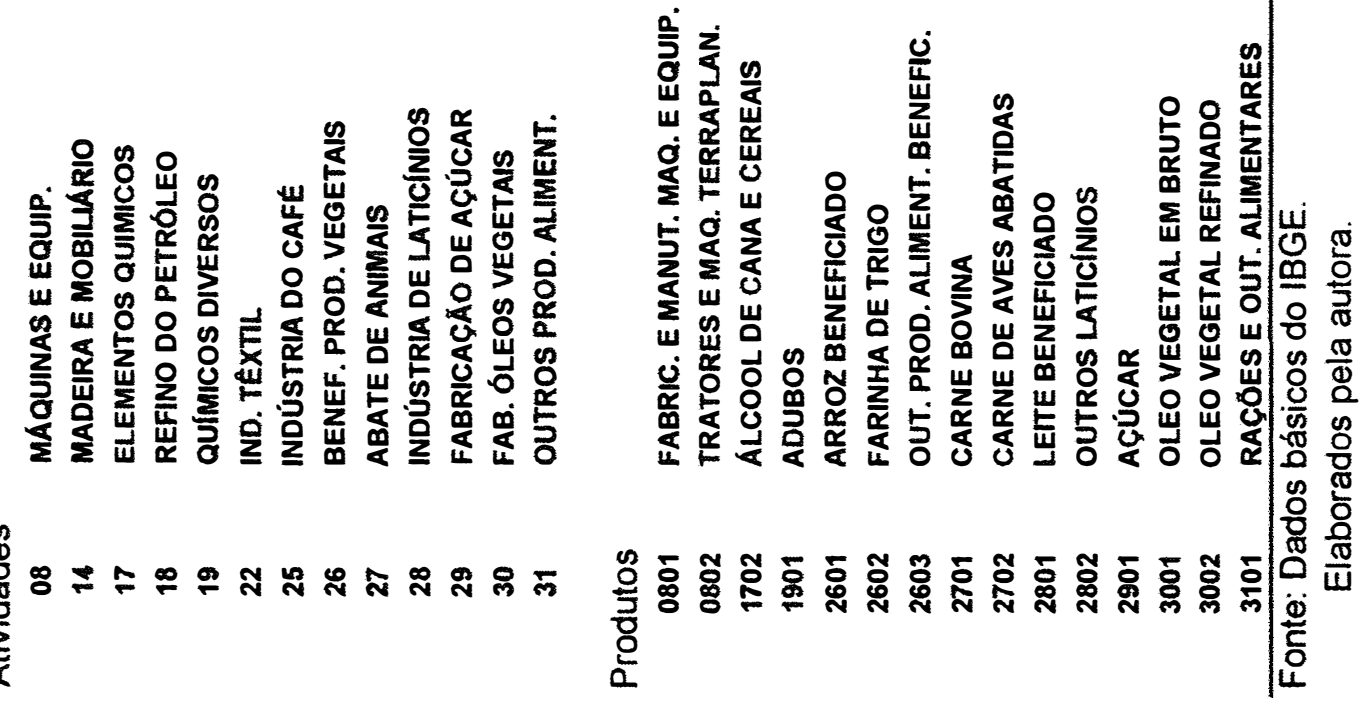
Љ ஐ

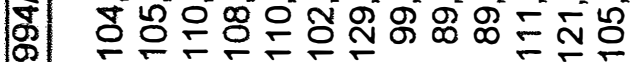

ส \&ล்

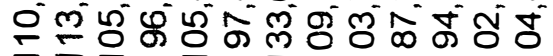

-

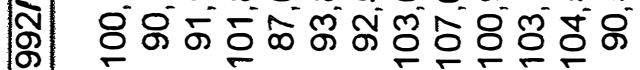

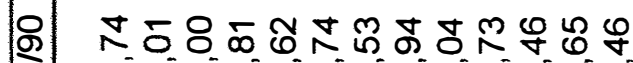

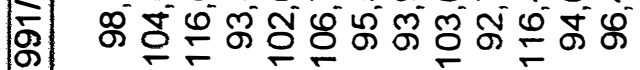

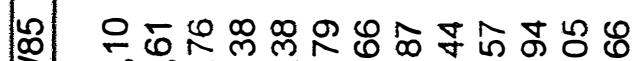
จ

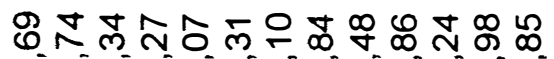

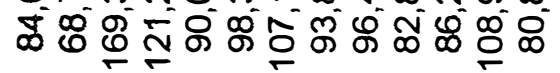

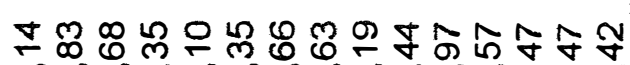

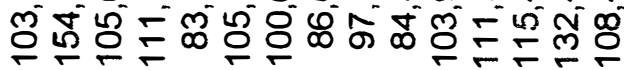

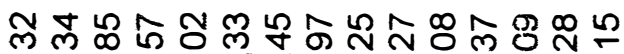

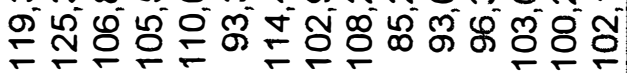

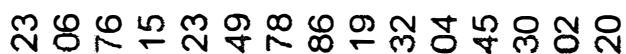

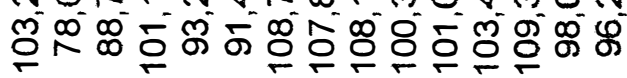

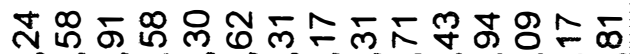

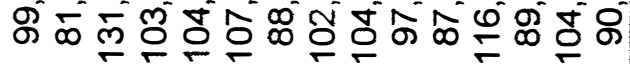

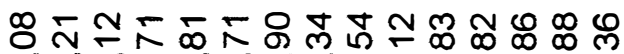

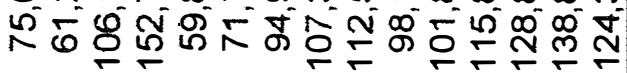

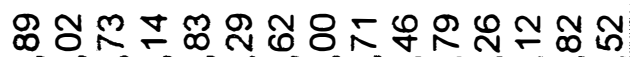

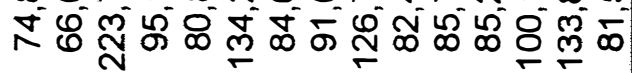

$$
\text { 离 }
$$
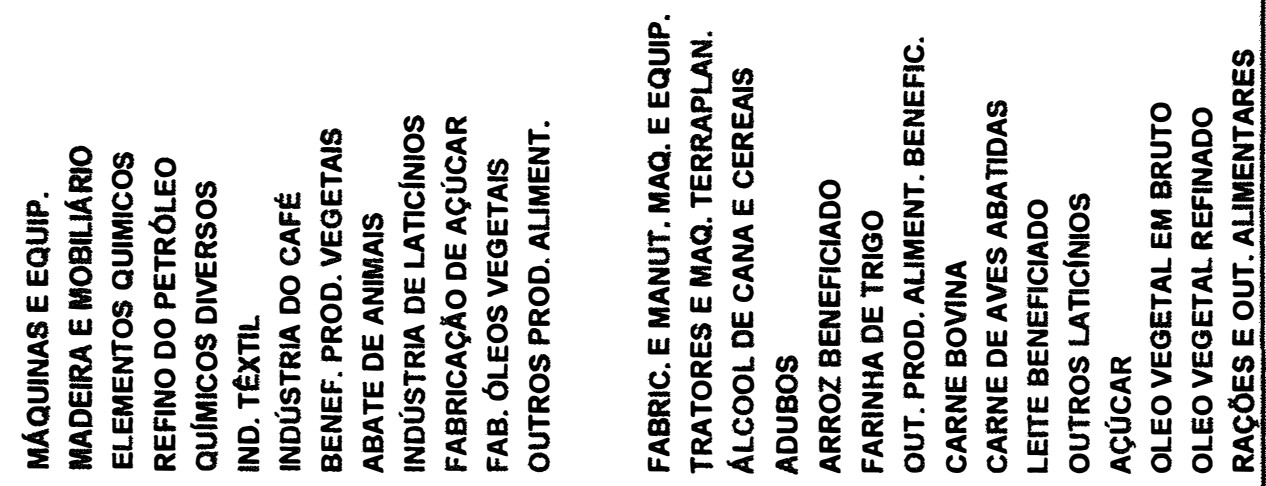
1) 